MARINA DUBOIS FAVA

\title{
APLICAÇÃO DAS NORMAS DO CDC AOS CONTRATOS INTEREMPRESARIAIS: A DISCIPLINA DAS CLÁUSULAS ABUSIVAS
}

\author{
DisSertação de MeSTRado
}

Orientador: Prof. Dr. Paulo Salvador Frontini

FACULDADE DE DIREITO DA USP

SÃO PAULO

2010 
MARINA DUBOIS FAVA

\section{APLICAÇÃO DAS NORMAS DO CDC AOS CONTRATOS INTEREMPRESARIAIS: A DISCIPLINA DAS CLÁUSULAS ABUSIVAS}

Dissertação de Mestrado apresentada à Banca Examinadora da Faculdade de Direito da Universidade de São Paulo, como exigência parcial para a obtenção do título de Mestre em Direito, sob orientação do Prof. Dr. Paulo Salvador Frontini

FACULDADE DE DIREITO DA USP SÃO PAULO 2010 
Banca Examinadora 


\section{RESUMO}

O presente estudo tem por objetivo demonstrar a necessidade de se tutelar a desigualdade substancial existente nas relações contratuais celebradas entre empresários, quando uma das partes, ainda que profissional, encontrar-se em situação de dependência econômica, favorecendo o abuso da parte contrária na situação concreta.

O cerne do trabalho gira em torno do problema das cláusulas abusivas no âmbito dos contratos interempresariais. Busca-se demonstrar que, nas hipóteses em que não for possível repreendê-las por meio da aplicação do Código Civil ou da Lei Antitruste, seria possível equiparar o contratante vulnerável, sujeito a um abuso por parte de seu parceiro contratual, aos consumidores, para fins de aplicação dos dispositivos do Código de Defesa do Consumidor - CDC ao contrato em questão.

Para tanto, são analisados os conceitos de empresário, de consumidor - tendo em vista as três principais correntes doutrinárias existentes no ordenamento pátrio - e de dependência econômica. Especificamente em relação à definição de consumidor, tenta-se demonstrar que, nos dias de hoje, a Teoria Finalista Aprofundada parece ser a que melhor atende à necessidade de se buscar a solução mais justa no caso concreto, sem, contudo, banalizar a aplicação do CDC.

Por fim, faz-se uma análise da jurisprudência brasileira sobre o tema, com o objetivo de delimitar os critérios para a incidência do CDC em contratos interempresariais, bem como os principais casos em que o conceito de consumidor-equiparado tem prevalecido nos litígios decorrentes de tais contratos.

Palavras-chave: CONSUMIDOR - CDC - EMPRESÁRIO - CLÁUSULAS ABUSIVAS DEPENDÊNCIA ECONÔMICA - $\quad$ CONTRATOS INTEREMPRESARIAIS 


\section{ABSTRACT}

The objective of the present study is to demonstrate the need of instructing the substantial inequality existing in contractual relations signed between businessmen, when one of the parties, although still professional, finds itself in a situation of economic dependence, favoring the abuse of the counterpart in the real situation.

The core of this work involves the problem regarding abusive clauses in the scope of inter-business contracts. It seeks to demonstrate that, in hypothesis where it is not possible to reprehend them by means of application of the Civil Code or Antitrust Act, it would be possible to match the vulnerable contracting party, subject to an abuse by its contractual partner, to the consumers, for purposes of application of the provisions in the Consumer Defense Code - CDC to the contract in question.

To do so, it analyzes the concepts of businessman and consumers - considering the three main doctrinaire schools of thought existing in the country system - and economic dependence. Specially in relation to the definition of consumers, it attempts to demonstrate that, nowadays, the In-depth Finalist Theory seems to be the best theory that meets the need of searching for the more righteous solution in the real case, without, however, trivializing the application of the CDC.

At last, an analysis of Brazilian jurisprudence is made on the subject, aiming to delimitate the criteria for the incidence of CDC in inter-business contracts as well as the main cases in which the concept of consumer has prevailed in such contracts for one of the parties.

Keywords: CONSUMER - CDC - BUSINESSMEN - ABUSIVE CLAUSES ECONOMIC DEPENDENCE - INTER-BUSINESS CONTRACTS 


\section{SUMÁRIO}

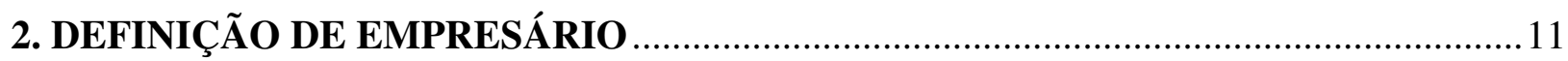

2.1. Evolução do direito comercial: a Teoria da Empresa no Brasil.........................................11

2.2. Unificação do direito civil e do direito comercial no Brasil ...............................................13

2.3. Conceito de empresário no Código Civil de 2002 .......................................................... 17

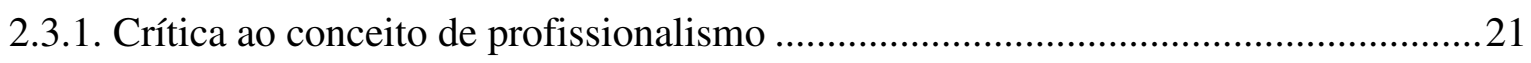

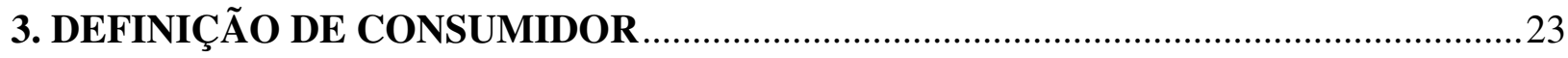

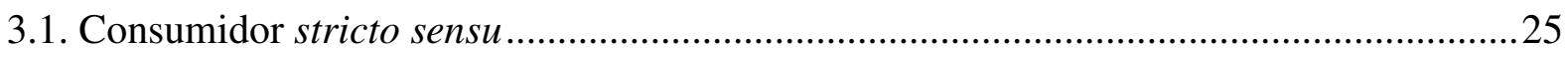

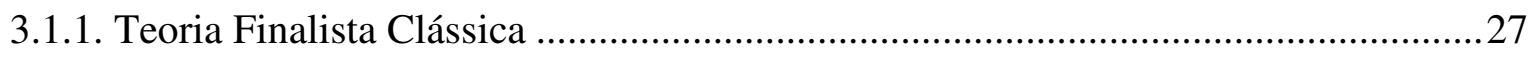

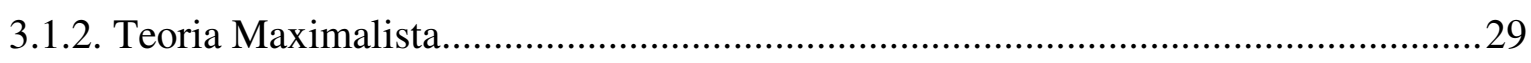

3.1.3. Teoria Finalista Aprofundada ..............................................................................

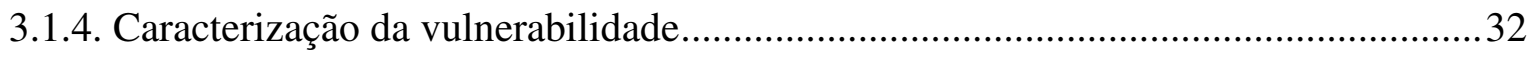

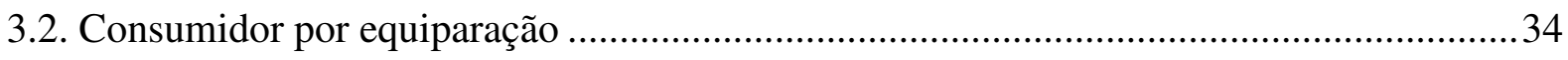

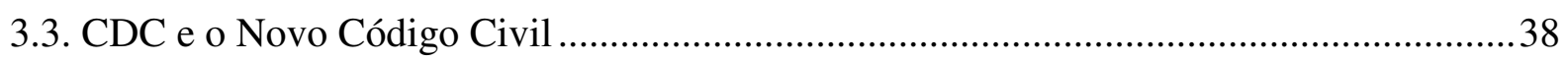

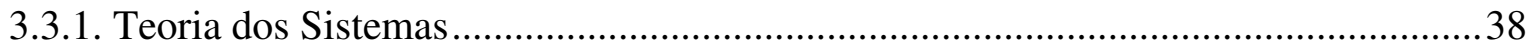

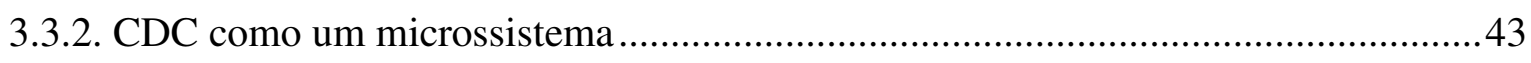

3.3.3. Diálogo das fontes entre CDC e Código Civil …………………………………........4

4. CARACTERIZAÇÃO DA DEPENDÊNCIA ECONÔMICA ………………………..........

4.1. Surgimento da noção de dependência econômica no âmbito contratual.............................51

4.2. Classificação da dependência econômica segundo Calixto Salomão Filho.........................57

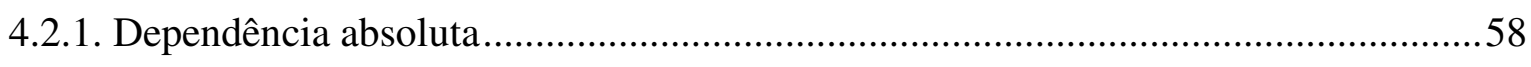

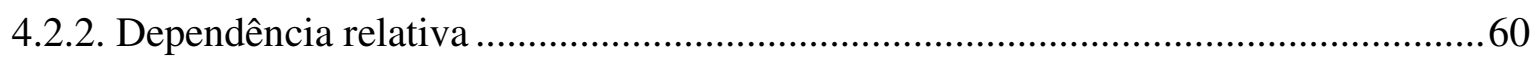

4.3. Importância do reconhecimento da dependência econômica no âmbito contratual...........62

4.4. Diversidade dos contratos de dependência econômica .....................................................63

4.5. Caracterização da dependência econômica segundo os critérios de Georges J.

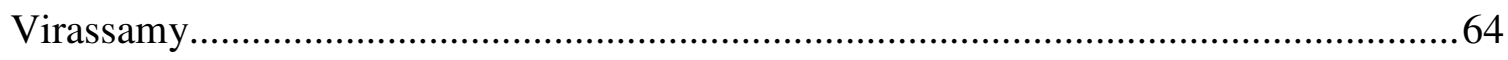

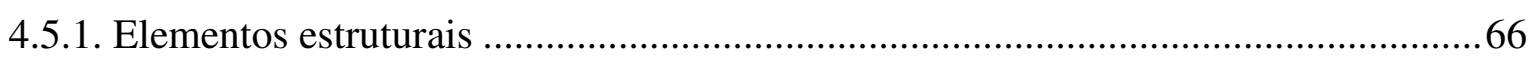

4.5.2. Elementos objetivos de reforço da dependência econômica .........................................67

4.5.3. Elementos contratuais de reforço da dependência econômica ......................................68

4.6. Consequiência direta da dependência econômica: a subordinação ......................................70

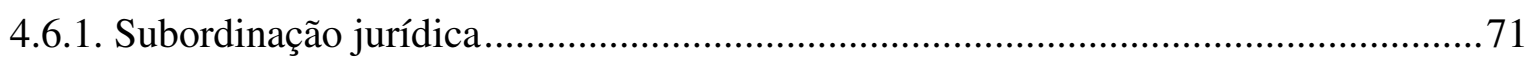

4.6.2. Subordinação profissional .................................................................................. 
4.7. Ordenança francesa de $1^{\circ}$ de dezembro de 1986: a caracterização do abuso de dependência econômica

4.7.1. Situação de dependência ...........................................................................................73

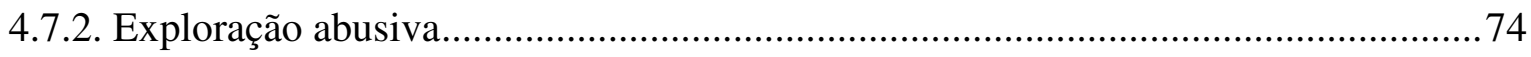

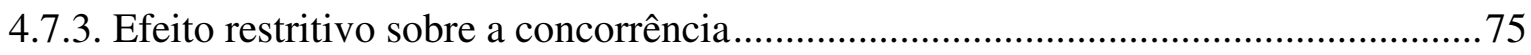

\section{DEPENDÊNCIA ECONÔMICA NO ÂMBITO CONTRATUAL E O CONCEITO}

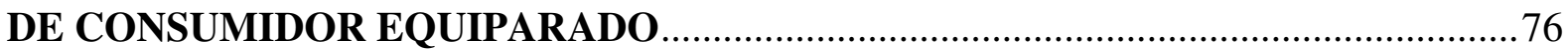

5.1. Lógica do direito empresarial versus equiparação de empresário a consumidor..............76

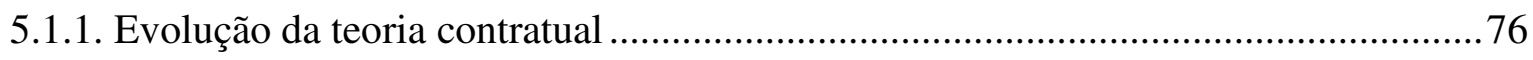

5.1.2. Interpretação dos contratos no ordenamento brasileiro.......................................... 81

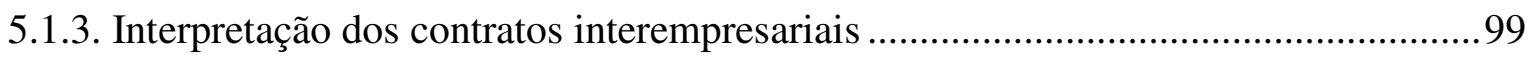

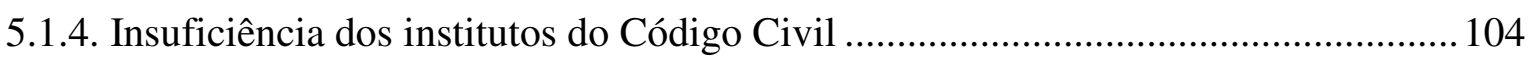

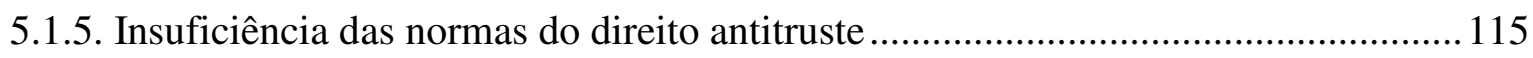

5.1.6. Aplicação das normas do CDC aos contratos interempresariais: desvirtuamento

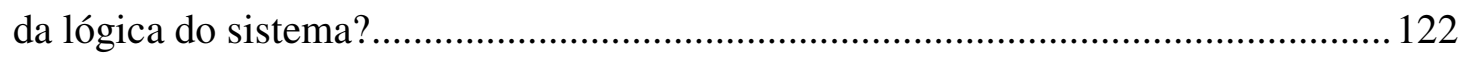

5.2. Caracterização do empresário como consumidor: uma realidade possível no direito brasileiro?.

5.3. Principais conseqüências da aplicação do CDC aos contratos interempresariais: a disciplina das cláusulas abusivas

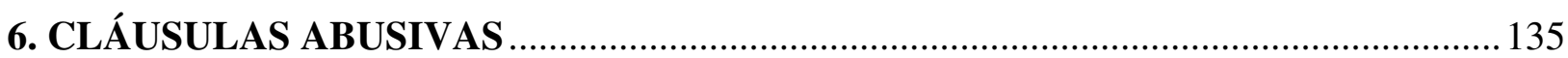

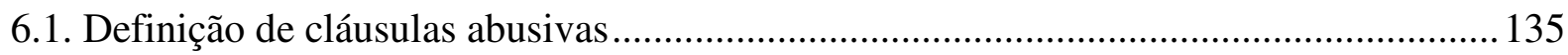

6.2. Cláusulas abusivas no Código Civil e no CDC............................................................. 138

6.2.1. Cláusulas abusivas no Código Civil ....................................................................... 139

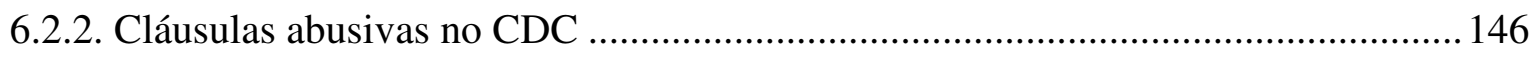

6.3. Equiparação de empresário a consumidor e as cláusulas abusivas ................................ 149

6.4. Aplicação das disposições sobre cláusulas abusivas do CDC aos contratos

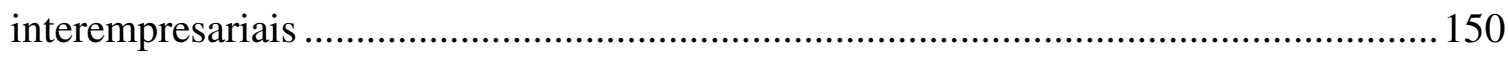

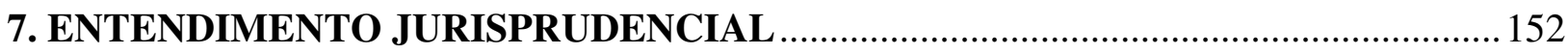

8. CONCLUSÃ

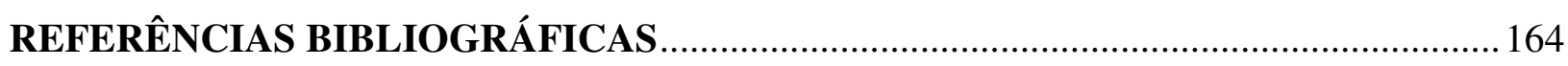




\section{INTRODUÇÃO}

A evolução contratual encaminhou-se num sentido de relativizar os primados, antes absolutos, da autonomia da vontade e da força obrigatória do contrato, haja vista que ambos tinham por fundamento uma noção equivocada: a igualdade formal entre as partes. Em verdade, o que se verifica no mundo fático e fenomênico é uma desigualdade real entre os contratantes, até mesmo entre profissionais, fato que levou ao surgimento de uma "nova" teoria contratual, baseada em princípios que, de certa forma, limitam a autonomia da vontade e a liberdade contratual, como a boa-fé objetiva e a função social do contrato.

$\mathrm{Na}$ esteira dessas novas considerações acerca da teoria contratual, passou-se a dar grande valor à análise das posições econômico-hierárquicas dos contratantes, o que veio a culminar com a aplicação da teoria do abuso de poder econômico também em âmbito contratual.

Essa mesma evolução propiciou o surgimento, paralelamente aos antigos tipos contratuais existentes, de uma enorme gama de novos contratos, denominados atípicos, que buscavam contemplar as necessidades atuais da economia e do mercado, conjugando, em um mesmo contrato, fatores que antes eram exclusivos de mais de um tipo contratual. Também em virtude dessa evolução, surgiu um novo modo de estipulação contratual, capaz de atender à celeridade do mundo negocial moderno e à necessidade de distribuição em massa: os contratos de adesão.

O Código de Defesa do Consumidor (“CDC”), muito antes da entrada em vigor do Código Civil de 2002, já contemplava grande parte das preocupações acima apontadas, e, assim como o direito da criança e do adolescente ou o direito do locatário, por exemplo, justifica-se em razão de um certo "papel social" que é atribuído ao grupo de pessoas especiais que tutela. Tais normas, segundo TERESA NEGREIROS, são classificadas como weak-person-related ${ }^{1}$. Porém, a disciplina do $\mathrm{CDC}$, em regra, não pode ser estendida às relações entre profissionais, salvo em alguns casos específicos, conforme será demonstrado

\footnotetext{
${ }^{1}$ Cf. NEGREIROS, Teresa. Teoria do contrato: novos paradigmas. 2. ed. Rio de Janeiro: Renovar, 2006. p.
} 321. 
ao longo do presente trabalho, sob pena de cair por terra a função tão prestigiada do referido código consumerista ${ }^{2}$.

Diante dessas novas preocupações em âmbito contratual, surgiu um conceito para abarcar a desigualdade real existente entre os contratantes profissionais, já que o direito comum, em um primeiro momento, se preocupou em tutelar apenas as desigualdades existentes nos contratos de trabalho e de consumo, qual seja, o conceito de contratos de dependência, fruto da dependência econômica de uma das partes em relação a seu parceiro comercial.

Os contratos de dependência, via de regra contratos sucessivos e de adesão, são caracterizados por levar uma das partes à dependência empresarial, subordinando-se esta última profissionalmente à parte em posição de superioridade. Alguns elementos dessa dependência e de sua conseqüente subordinação profissional, que pode se dar mediante a imposição de algumas cláusulas pelo contratante economicamente mais forte, serão destacados ao longo do presente estudo.

A existência dessa situação de dependência econômica, porém, não deve ser condenada per se, pois se trata apenas de uma situação de fato. O que se deve evitar é que a parte que se encontre em posição de superioridade venha a se utilizar dessa situação para obter vantagens pessoais em detrimento da parte mais fraca e da função social do contrato.

Nessa mesma linha de pensamento, RIPERT afirma que “ce n'est pás l’inégalité des contractants qui, par elle seule, rend le contrat suspect, c'est l'abus possible qui sortira de

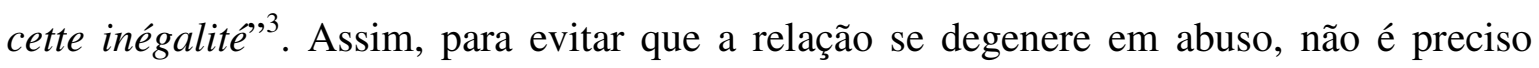
buscar explicitar o desequilíbrio existente, mas sim assegurar que uma das partes não tenha condições de explorar a fragilidade da outra.

O objetivo do presente trabalho será tentar apresentar uma solução para um caso específico de abuso pela parte economicamente mais forte no âmbito dos contratos interempresariais: a imposição de cláusulas abusivas. Para tanto, será analisada a disciplina das cláusulas abusivas no ordenamento brasileiro, seja pela aplicação do Código Civil, seja

\footnotetext{
${ }^{2}$ A partir da valorização, no âmbito contratual, dos chamados "direitos de terceira geração", relacionados com o princípio da fraternidade, com a pacificação social e com a busca do equilíbrio nas relações negociais, o tema "direito do consumidor" ganhou relevância na atual sistemática do Direito Privado, cabendo aos estudiosos e operadores do direito encontrar um ponto de equilíbrio entre a sua socialização e a manutenção da segurança do sistema. (Cf. TARTUCE, Flavio. A revisão do contrato no Código de Defesa do Consumidor e a suposta adoção da teoria da imprevisão: visão frente ao princípio da função social do contrato. Disponível em: <http://www.flaviotartuce.adv.br/secoes/artigos.asp>. Acesso em: 22 dez. 2008).

${ }^{3}$ RIPERT apud GRAC, Stéphane. Les relations juridiques entre franchiseur et franchisé: coopération et conflit. Thèse pour le Doctorat présentée a l'Université de Nice-Sophia Antipolis, 1999. p. 74.
} 
pela aplicação do CDC, seja, ainda, pela tutela concorrencial, atribuindo-se especial enfoque às situações de equiparação de empresários a consumidores, nos termos do art. 29 do diploma de proteção consumerista.

Para se chegar à possibilidade de proteção das cláusulas abusivas no âmbito dos contratos interempresariais por meio da aplicação das normas do CDC, será feita uma análise das três teorias existentes na doutrina nacional sobre o conceito de consumidor, com o objetivo de se determinar qual delas, no sistema atual, é a mais coerente, bem como analisar-se-á a possibilidade de aplicação do CDC aos contratos interempresariais, tendo em vista o ordenamento jurídico nacional.

Nesse percurso, a aluna tentará demonstrar que os institutos do atual Código Civil ou a proteção oferecida pelo direito concorrencial deveriam ser suficientes para a correção dos desequilíbrios existentes nos contratos entre profissionais, mas, em alguns casos excepcionais, quando a tutela por esses outros ramos do direito se mostrar insuficiente, o CDC poderá ser aplicado.

A delimitação desses casos em que se justifica a aplicação do CDC aos contratos interempresariais, porém, é atividade extremamente delicada. Corre-se o risco de banalizar a aplicação desse diploma legal, trazendo por terra a sua função e os objetivos almejados quando de sua promulgação.

Com efeito, assim como ocorre com o Direito Penal e o Direito do Trabalho, a aplicação do CDC deve se restringir aos fatos realmente relevantes e dentro de critérios rigidamente estabelecidos, tendo em vista a finalidade de tal diploma legal. É justamente por isso que, no Direito Penal, tem-se o princípio da insignificância, o qual determina a não punição, ao menos não em âmbito penal, das condutas e perturbações socialmente irrelevantes, isto é, inofensivas, inexpressivas, sem periculosidade e cujo comportamento tenha um reduzidíssimo grau de reprovabilidade, como o furto de um pão, por exemplo. Da mesma forma, as regras trabalhistas somente devem ser aplicadas quando constatados todos os requisitos da relação de emprego.

A aplicação do CDC a contratos interempresariais quando ele não deveria ser aplicado acabaria por minar com a sua nobre função de proteção da parte vulnerável na relação contratual, beneficiando quem não deveria ser beneficiado, e maculando, inclusive, o princípio da igualdade substancial, consagrado na Constituição Federal de 1988, que preconiza o tratamento igual aos iguais e desigual aos desiguais. 
Ademais, é de se lembrar, como bem ressaltou COMPARATO, que se a consagração da defesa do consumidor na Constituição Brasileira de 1988 representou inegável progresso no plano normativo, deve-se afastar desde logo a ilusão de que os problemas sociais se resolvem pela simples edição de normas jurídicas. Antes de mais nada, deve-se primar pelo desenvolvimento nacional, com o crescimento econômico auto-sustentado e a progressiva igualização de condições de vida ${ }^{4}$.

Destarte, é indispensável criar um direito apropriado à realidade brasileira, deixando-se de "copiar" direitos alienígenas, como é de costume em nosso país. Nesse passo, é importante observar que uma das adaptações a ser feita à realidade brasileira é a de que muitos empresários, ao contrário do que ocorre nos países altamente desenvolvidos, são completamente vulneráveis e inexperientes, daí porque reclamam uma equiparação ao conceito de consumidor, para se verem beneficiados também pelas normas consumeristas.

Por fim, será feita uma abordagem do assunto em sede jurisprudencial, de forma a traçar os principais argumentos utilizados por nossos tribunais, o entendimento majoritário que tem sido adotado nos casos práticos, bem como as tendências apresentadas pelos magistrados para os próximos anos.

${ }^{4}$ Cf. COMPARATO, Fabio Konder. A proteção ao consumidor na Constituição Brasileira de 1988. Revista de Direito Mercantil, Industrial, Econômico e Financeiro, São Paulo, n. 80, p. 75, 1990. 


\section{DEFINIÇÃO DE EMPRESÁRIO}

\subsection{Evolução do direito comercial: a Teoria da Empresa no Brasil}

O comércio é a atividade humana que visa colocar em circulação as riquezas produzidas e é tão antigo quanto a própria civilização. Ainda que de forma bastante rudimentar, já era possível notar a existência de trocas de bens e a conjugação de esforços para a obtenção de resultados econômicos comuns entre os povos primitivos.

Sob o aspecto jurídico, o comércio é o complexo de atos exercidos habitualmente ou profissionalmente de intromissão entre o produtor e o consumidor, visando ao lucro. Do aspecto jurídico, decorrem as três características do comércio, que são: a mediação, o profissionalismo e a lucratividade.

O direito comercial, mais recente que o comércio, surgiu como um direito separado do direito civil, resultante das necessidades e exigências do comércio por uma legislação mais simples, de origem essencialmente consuetudinária e inspirada em novos princípios. Primeiramente, surgiu como um direito classista, que buscava suprimir as lacunas que o direito romano não preenchia, num momento em que as condições econômicas e políticas na Europa da Baixa Idade Média se tornaram favoráveis ao desenvolvimento do comércio. Tais condições favoráveis decorreram da injeção de capital que a Europa recebeu com os saques nas cruzadas, do restabelecimento das rotas comerciais com o Oriente e do incipiente processo de urbanização pelo qual passava o referido continente ${ }^{5}$.

Para acompanhar a evolução das necessidades e circunstâncias de cada época, o direito comercial também evoluiu ao longo do tempo, sendo possível notar a existência de três períodos desse ramo do direito, a saber: (i) período subjetivo das corporações de ofício; (ii) período objetivo dos "atos do comércio"; e (iii) período moderno, que instituiu a “Teoria da Empresa".

Entre os séculos XII e XVII, a definição de comerciante estava totalmente voltada para a pessoa que exercia a atividade. Assim, eram considerados comerciantes somente

\footnotetext{
${ }^{5}$ Cf. STAGNI, Alexandre; NOGUEIRA, André Coutinho; CABELEIRA, Caio; OUCHANA, Elber Christian; GOMES, Guilherme Amado. Os princípios peculiares do direito comercial e a aplicação do Código de Defesa do Consumidor aos contratos interempresariais. Revista de Direito Mercantil, Industrial, Econômico e Financeiro, São Paulo, n. 145, p. 220-221, jan./mar. 2007.
} 
aqueles que estivessem matriculados nas corporações de ofício, as quais abrangiam atos que não eram propriamente mercantis, tal qual a venda do imóvel residencial do comerciante $e^{6}$.

A partir do século XVII, passou-se a adotar uma definição objetiva, considerandose comerciantes apenas aqueles que praticassem os atos discriminados em lei como "mercantis". Tal teoria, que ficou conhecida como "Teoria dos Atos do Comércio", foi adotada inicialmente no Código Comercial francês de 1808, estando posteriormente presente no Código Comercial brasileiro de 1850 e no Código Comercial português de 1883.

Os atos do comércio, como eram chamados por essa teoria, eram caracterizados pela sua natureza, por força de lei ou por conexão. A própria natureza do ato ou alguma lei deveria identificá-lo como atividade comercial, ou o ato deveria estar conectado a uma atividade final de comércio. Os prestadores de serviço, porém, exceto quando constituídos sob a forma de sociedade anônima, estavam excluídos desse regime.

Em razão da deficiência de tal teoria, portanto, que não contemplava inúmeras atividades econômicas, além de não estar apta a responder às necessidades do mercado e da sociedade após o aumento da complexidade das relações econômicas, passou-se à terceira fase, que teve início a partir da década de 1940, quando o Código Civil italiano adotou a "Teoria da Empresa". Por esta teoria, considera-se empresário aquele que exerce atividade econômica organizada, visando à produção ou circulação de bens e/ou serviços.

No direito brasileiro, já era possível notar raízes da "Teoria da Empresa" na própria Constituição Federal de 1988, bem como em algumas leis especiais, tais como a Lei da Micro e Pequena Empresa (Lei no . 9.841/99, a qual foi, posteriormente, substituída pela Lei Complementar 123/06, alterada pela Lei Complementar 127/07), a Lei Antitruste (Lei $n^{\circ}$. 8.884/94) e a Lei das Sociedades Anônimas (Lei no. 6.404/76). Todavia, somente com a entrada em vigor do Código Civil de 2002, como se verá a seguir, é que a Teoria da Empresa foi definitivamente arraigada em nosso ordenamento, ficando superado o conceito de comerciante, para dar lugar ao conceito de empresário.

\footnotetext{
${ }^{6}$ Parte do fracasso do período subjetivo das corporações de ofício se deve ao fato de que muitas pessoas, embora exercessem o comércio, não podiam ser inscritas nas corporações de ofício, como os eclesiásticos, os nobres e os estrangeiros (Cf. VIVANTE, Cesare. Trattato di diritto commerciale. 5.ed. Milano: Casa Editrice Dott. Francesco Vallardii, 1922. v. 1, p. 5).
} 


\subsection{Unificação do direito civil e do direito comercial no Brasil}

Com a entrada em vigor do novo Código Civil, em janeiro de 2003, houve a revogação parcial do Código Comercial de 1850 (revogação da primeira parte), bem como do Decreto $\mathrm{n}^{\text {o }} 3.708$ de 1919, que regulava as sociedades ditas "por quotas de responsabilidade limitada", as quais passaram a ser reguladas pelo novo código sob o nome de "sociedades limitadas".

O Código Civil de 2002 inseriu-se no sistema já existente com o objetivo de adequar o tratamento legislativo dado a certas condutas e relações, que eram tratadas de maneira obsoleta no antigo código, para acompanhar a evolução jurídica que já vinha sendo observada em alguns países estrangeiros. Nessa linha de raciocínio, o legislador brasileiro optou pela unificação entre a "base nuclear" do direito comercial e do direito civil em um mesmo diploma legal, sendo que, após parcial supressão do primeiro, foi elaborada toda uma compilação ao redor do segundo, de forma a tentar englobar as duas matérias $^{7}$ e 8 . Assim como havia ocorrido na Itália e na Suíça, entretanto, a unificação no Brasil se deu apenas no aspecto formal ${ }^{9}$, uma vez que o direito comercial continua revestido de certo particularismo e autonomia, regido por alguns princípios que lhe são próprios, decorrentes de sua origem histórica ${ }^{10}$. Além de formal, a unificação ocorrida foi meramente parcial, limitando-se ao direito das obrigações. Inúmeras questões que também integram o Direito Privado continuam sendo regidas por leis especiais, como é o caso das sociedades anônimas, dos procedimentos falimentares e de recuperação de empresas, do direito do trabalho, e tantos outros institutos de Direito Privado ${ }^{11}$.

${ }^{7}$ Cf. STAGNI, Alexandre; NOGUEIRA, André Coutinho; CABELEIRA, Caio; OUCHANA, Elber Christian; GOMES, Guilherme Amado. op. cit., p. 225-226.

${ }^{8}$ SYLVIO MARCONDES explica que "a elevação e disseminação da cultura, o enorme progresso científico, a expansão da produção e circulação de toda sorte de bens, conduzem a um processo de democratização da riqueza, favorável à multiplicação dos atos econômicos e da sua prática por pessoas em número cada dia maior. Negócios jurídicos quase privativos de uma classe, como a dos comerciantes, passam a constituir rotina cotidiana de todos. Acelera-se o que, tão ao gosto da doutrina francesa, se tem admitido chamar de 'comercialização do direito civil', corroborando um 'civilismo do direito comercial'. Expressões de tendência para uniformizar o procedimento jurídico da prática econômica e fundi-lo num só corpo de lei, posto a serviço de todos os sujeitos, sem discriminações" (MARCONDES, Sylvio. Problemas de direito mercantil. São Paulo: Max Limonad, 1970. p. 130).

${ }^{9} \mathrm{~A}$ codificação atualmente é única, mas ainda não é possível afirmar que existe um único direito.

${ }^{10} \mathrm{Cf}$. KLEE, Antonia Espíndola Longoni. A unificação do direito privado e as relações entre o Código de Defesa do Consumidor e o Código Civil. Disponível em: $<$ http://www.cjf.jus.br/revista/numero39/artigo08.pdf>. Acesso em: 04 nov. 2009.

${ }^{11}$ Cf. MUSSI, Luiz Daniel Rodrigues Haj. Abuso de dependência econômica nos contratos interempresariais de distribuição. 2007. Dissertação (Mestrado) - Faculdade de Direito, Universidade de São Paulo, São Paulo, 2007. p. 111. 
Pouco antes da unificação do Direito Privado na Itália, que ocorreu com a entrada em vigor do Código Civil de 1942, VIVANTE já apontava para a desnecessidade desses dois ramos do Direito caminharem de forma autônoma. Segundo o jurista, a autonomia do direito comercial, que se conservava apesar da grande uniformidade da vida moderna, parecia se sustentar muito mais por força da tradição do que por uma boa razão. Aponta o autor, ainda, que a possiblidade de uma mesma teoria geral regular todas as relações privadas já era quotidianamente adotada pela jurisprudência americana e inglesa, que não chegaram sequer a conhecer uma teoria especial com regras particulares aplicáveis somente aos comerciantes ${ }^{12}$.

Embora a unificação prática do direito obrigacional na Itália e Suíça tenham ocorrido antes que no Brasil ${ }^{13}$, foi o jurista brasileiro AUGUSTO TEIXEIRA DE FREITAS o primeiro a defender a unidade desses dois ramos do direito. Já em 1827, no Esboço de Código Civil, TEIXEIRA DE FREITAS propunha a unificação das obrigações civis e comerciais. O grande jurista, contudo, veio a falecer sem ver sua vontade concretizada ${ }^{14}$.

Posteriormente, inúmeros juristas no Brasil tentaram defender os ideais de unificação lançados por TEIXEIRA DE FREITAS ${ }^{15}$, mas, além do projeto desse jurista, o propósito uniformizador recebeu estímulo principalmente pelos projetos de INGLEZ DE SouzA. Ao contrário de seu antecessor, que evoluiu do Esboço de Código Civil para o plano de códigos unificados, INGLEZ DE SOUZA oferecia, ao lado do projeto de Código Comercial, o de emendas destinadas a transformá-lo em código de Direito Privado. Muito embora partissem de lados opostos, ambos tinham o mesmo objetivo ${ }^{16}$.

Tal opção legislativa, porém, não deixou de causar polêmica. Desde a elaboração do projeto de lei que viria a ser convertido no atual Código Civil brasileiro, é possível notar a existência de duas correntes na doutrina pátria ${ }^{17}$. A primeira que não vê problema algum na inserção das regras comerciais em uma parte específica do Código Civil, e uma segunda que acredita que tal diploma legal não possui elementos suficientes que o tornem habilitado para lidar com as regras do mercado.

\footnotetext{
${ }^{12}$ Cf. VIVANTE, Cesare. op. cit., v. 1, p. 8-10.

${ }^{13}$ Recentemente, outros países também aderiram ao propósito uniformizador em seus respectivos códigos, a saber: Paraguai (1986), Canadá (1994) e Holanda (1992). Sobre o tema, vide: KLEE, Antonia Espíndola Longoni. op. cit.

${ }^{14}$ Cf. KLEE, Antonia Espíndola Longoni. op. cit.

${ }^{15}$ Pode-se citar Costa e Silva, Coelho Rodrigues, CARvalho DE MENDOnÇA, dentre outros.

${ }^{16}$ Cf. MARCONDES, Sylvio. op. cit., p. 130-131.

${ }^{17}$ A distinção entre as duas correntes, esboçada nos parágrafos seguintes a este, teve por base o artigo de STAGNI, Alexandre; NOGUEIRA, André Coutinho; CABELEIRA, Caio; OUCHANA, Elber Christian; GOMES, Guilherme Amado. op. cit., p. 226-227.
} 
O primeiro grupo de juristas não enxerga nessa unificação legislativa um possível prejuízo à autonomia jurídica do direito comercial, uma vez que as regras referentes a esse ramo do direito encontram-se inseridas em uma "parte especial" denominada "Do Direito da Empresa", representada por 229 artigos no Livro II da Parte Especial, cujo conteúdo foi baseado no Código Civil italiano de 1942. Dessa forma, a matéria comercial não se confunde com a matéria civil no novo código, sendo este um dos fatores que evidencia a autonomia jurídica do direito comercial $^{18}$. Segundo essa corrente, ademais, o direito comercial, atualmente, vive um momento de incertezas, em detrimento da constante transformação pela qual passam praticamente todos os setores sociais, em especial o das relações econômicas regidas por forças comerciais, e é nesse ponto que surge a nova lei, com o intuito, pelo menos inicial, de “(...) transpor o período de transição do direito comercial, consolidando-o como o direito da empresa, maior e mais adequado para disciplinar o desenvolvimento das atividades econômicas no país"19.

O local onde estão inseridas essas novas normas, contudo, não configura o principal aspecto da inovação, fazendo-se necessária uma análise de conteúdo e da maneira (nova ou não) como tais normas passaram a reger seus âmbitos de atuação, e não apenas uma análise do ponto de vista científico.

Outro grupo de juristas, porém, entende que o Código Civil de 2002, apesar de se afastar de uma imagem já potencialmente desgastada do direito comercial, acabou pecando em muitos aspectos na regulação do fluxo de relações econômicas, especialmente em razão de sua omissão no tocante às regras de interpretação. Como lembra PAULA FORGIONI:

“(...) o novo diploma silencia sobre a interpretação de cláusulas aparentemente contraditórias. Buscava o nosso velho e sábio Código a coerência na interpretação do texto negocial, permitindo sua correta aplicação conforme a função econômica almejada pelas partes" ${ }^{20}$.

\footnotetext{
${ }^{18}$ TADDEI, Marcelo Gazzi. O direito comercial e o novo Código Civil brasileiro. Disponível em: $<$ http://jus2.uol.com.br/doutrina/texto.asp?id=3004>. Acesso em: 24 dez. 2008.

${ }^{19}$ Id. Ibid.

${ }^{20}$ FORGIONI, Paula Andréa. A interpretação dos negócios empresariais no novo Código Civil brasileiro. Revista de Direito Mercantil, Industrial, Econômico e Financeiro, São Paulo, v. 42, n. 130, p. 32, abr./jun. 2003.
} 
JUNQUEIRA DE AZEVEDO, por seu turno, acredita que a introdução no sistema jurídico brasileiro, já extremamente complexo, de uma regulação unitária (igual) para as relações civis e comerciais poderia resultar num retrocesso ${ }^{21}$.

Deve-se reconhecer, contudo, o fato de que o direito comercial pode conviver com o direito civil num código unificado, assim como já convivia com o direito penal nas leis de repressão aos delitos comerciais, por exemplo, como bem apontou SYLVIO MARCONDES $^{22}$.

Independentemente de tal discussão, certo é que o atual Código Civil evoluiu em muitos aspectos, demonstrando uma preocupação muito maior que o código anterior com os valores sociais ligados ao respeito pela parte mais fraca e ao equilíbrio contratual. A análise dos contratos, e inclusive eventuais intervenções judiciais nos instrumentos contratuais, portanto, deve-se pautar sempre pelo equilíbrio contratual, evitando o surgimento de uma possível situação de abuso de dependência econômica. Nada obstante, deve-se partir do pressuposto de que o homem, "ativo e probo", não deve ser negligente em suas ações, evitando assim eventuais reivindicações infundadas e que desestabilizem o sistema como um todo.

Nesse sentido, conceitos e idéias como a possibilidade de resolução contratual por onerosidade excessiva, estado de perigo, lesão ou mesmo a própria função social dos contratos servem para apontar, na ótica dos interesses coletivos, uma tendência à supressão das vontades essencialmente individuais. A nova legislação, assim, deixa a cargo dos tribunais a responsabilidade pela interpretação em cada caso concreto, uma vez que os princípios passam a ser tomados sob uma perspectiva bastante aberta e abrangente. Aqui, reside uma das reclamações do segundo grupo de juristas, que critica a unificação das duas matérias.

Além da unificação entre direito civil e direito comercial propriamente dita, o Código Civil em vigor trouxe como grande inovação um novo enfoque no tratamento dado à matéria comercial ao adotar a já mencionada "Teoria da Empresa".

A adoção dessa teoria não constitui propriamente uma inovação, mas sim um reflexo das transformações pelas quais já vinha passando o direito comercial, as quais

\footnotetext{
${ }^{21}$ Cf. AZEVEDO, Antonio Junqueira de. O direito pós-moderno e a codificação. In: pareceres de direito privado. São Paulo: Saraiva, 2004. p. 62.

${ }^{22}$ Cf. MARCONDES, Sylvio. op. cit., p. 130. Estudos e
} 
abalavam a própria estrutura conceitual desse ramo do direito, fundada anteriormente no conceito subjetivo de comerciante e objetivo de "atos do comércio", como se viü ${ }^{23}$.

Como bem lembrou SYLVIO MARCONDES:

"Cuida-se, portanto, não apenas de reunir diplomas, mas unir institutos, num sistema capaz de conjugar os que merecem ficar, com os modernos conceitos e os novos instrumentos de progresso econômico e social, forjados pelo direito desta nação e das que lhe são afins na grande família latino-romana" ${ }^{\text {"24. }}$.

A Teoria da Empresa foi refletida, especialmente, na definição de empresário do art. 966 do Código Civil de 2002, como será abordado a seguir.

\subsection{Conceito de empresário no Código Civil de 2002}

O conceito de empresário, atualmente, encontra-se no art. 966 do Código Civil, o qual dispõe que: "considera-se empresário quem exerce profissionalmente atividade econômica organizada para a produção ou circulação de bens ou de serviços". Tal definição vale tanto para o empresário individual, quanto para as sociedades empresárias.

A partir do conceito legal de empresário, é possível extrair três elementos, a saber: (i) a presença de uma atividade econômica; (ii) o exercício profissional da atividade; e (iii) a existência de uma atividade organizada.

Embora o dispositivo em comento não exija expressamente o escopo de lucro, a maior parte da doutrina entende que este é um dos requisitos para a caracterização do empresário ou sociedade empresária. A linha de argumentação vai no sentido de que, ao mencionar o termo "atividade econômica", o legislador implicitamente exigiu o escopo de lucro. Toda atividade necessita de recursos econômicos, mas quando o legislador menciona “atividade econômica", quis se referir à atividade destinada à criação de riqueza, seja pela produção de bens ou serviços, seja pela circulação dos bens ou serviços produzidos. Assim,

\footnotetext{
${ }^{23}$ Nas palavras de SYlVIO MARCONDES, "a atividade mercantil (...) se coloca no campo mais ativo do processo econômico nacional e, por isso, o Código de 1850, encolhido nos poucos preceitos que lhe restam, não pode servir de paradigma à nova codificação. Elaborado na ausência de direito comum consolidado, produziu frutos de sabedoria e prudência, ainda reconhecidas nos textos que resistiram à ação do tempo. Mas sua sistemática foi estilhaçada pela superveniência de necessidades e, em conseqüência, de institutos, novos ou remodelados, numa legislação especial que lhe muda a extensão e a figura" (MARCONDES, Sylvio. op. cit., p. 132).

${ }^{24}$ MARCONDES, Sylvio. op. cit., p. 133.
} 
a atividade empresarial deveria necessariamente visar à obtenção de lucro em favor de quem a exerce. Há quem entenda, ainda, que o ânimo de lucro é uma idéia implícito ao profissionalismo do empresário ${ }^{25}$.

A doutrina italiana, contudo, questiona tal requisito, usando como exemplo a sociedade cooperativa e as empresas públicas, que poderiam apresentar todos os demais requisitos da atividade empresarial sem, contudo, perseguir o lucro, por qualquer razão, inclusive política ${ }^{26}$. No Brasil, a sociedade cooperativa foi, por força de lei, enquadrada como uma sociedade simples, nos termos do art. 982, parágrafo único, do Código Civil, mas a dicussão remanesceria no tocante às empresas públicas.

A própria doutrina italiana, porém, conclui que embora o escopo de lucro nem sempre seja perseguido como principal objetivo, ele acaba existindo, ainda que de forma indireta. Talvez o mais correto fosse falar, portanto, em economicidade, e não em escopo de lucro ${ }^{27}$.

O exercício profissional da atividade demanda que seja considerado empresário somente aquele que exercer a atividade como um ofício, e não esporadicamente. $\mathrm{O}$ exercício da atividade deve ser praticado de modo habitual, contínuo e sistemático. A continuidade, no entanto, não deve ser entendida em seu sentido absoluto, não se confundindo com perpetuidade ${ }^{28}$. Cabe lembrar que algumas empresas surgem com um propósito específico e, uma vez atingido o propósito, são desconstituídas. Tais empresas, portanto, já nascem com data para morrer, e nem por isso deixam de ser empresárias. A título ilustrativo, pode-se dizer que aquele que aliena o seu próprio veículo, por exemplo, não pode ser considerado empresário, mas aquele que negocia veículos habitualmente o é.

No caso da sociedade empresária, ademais, alguns autores entendem que sequer é exigido que a atividade empresária e a habitualidade na prática de tal atividade já tenham se iniciado, desde que tal sociedade já tenha dado início aos atos preparatórios da empresa. Assim, ainda que o início das atividades não tenha ocorrido, o objeto social, constante do ato constitutivo, seria suficiente para determinar se ela é empresária ou não ${ }^{29}$. Todavia, o critério para a determinação do início da empresa deveria ser o mesmo para o empresário individual e para a sociedade empresária. Assim, para outra parte da doutrina, o elemento

\footnotetext{
${ }^{25}$ Nesse sentido, MARCONDES, Sylvio. Questões de direito mercantil. São Paulo: Saraiva, 1977. p. 11.

${ }^{26}$ Cf. BUONOCORE, Vincenzo. Trattado di diritto commerciale: l'impresa. Torino: G. Giappichelli, 2002. Sezione I, t. 2. I, p. 71-83.

${ }^{27}$ Cf. Id. Ibid., p. 83-89.

${ }^{28} \mathrm{Cf}$. Id. Ibid., p. 138-141.

${ }^{29}$ Cf. Id. Ibid., p. 95-99.
} 
essencial é o efetivo início da atividade econômica, especialmente porque após os atos preparatórios a intenção dos empreendedores pode vir a ser alterada ${ }^{30}$.

Vale apontar, ainda, que, em geral, a empresa pressupõe um estabelecimento, mas este por si só não confere a condição de empresário, já que um profissional autônomo pode também se estabelecer, sem com isso perder a condição de autônomo ${ }^{31}$. Da mesma forma, a necessidade de existência de um estabelecimento físico vem sendo cada vez mais questionada, especialmente em alguns novos setores, como ocorre com os empresários e sociedades empresárias que atuam somente no setor da Internet ${ }^{32}$.

Além dos requisitos já apontados, a atividade empresarial deve ser organizada, o que significa dizer que deve haver uma coordenação entre os fatores de produção em medida e proporção variáveis, conforme a natureza e o objeto da empresa ${ }^{33}$. O empresário deve coordenar adequadamente a junção do capital com a força de trabalho para um fim específico, qual seja, a produção ou circulação de bens e/ou serviços.

Em razão disso, alguns autores consideram a contratação de funcionários essencial para que reste caracterizada a empresa. Tal requisito, todavia, também vem sendo cada vez mais questionado em razão da tendência de robotização do trabalho e viabilização de diversas operações que anteriormente demandavam um estabelecimento físico e funcionários voltados para o atendimento ao cliente via Internet.

A doutrina italiana questiona o critério sob o argumento de que a organização da força de trabalho não demanda que o trabalho seja alheio, podendo existir casos em que haja uma organização do próprio trabalho. Seria o caso dos pequenos empresários, que poderiam se auto-organizar, sem necessariamente contratar funcionários. $\mathrm{O}$ exemplo citado é o de uma lavanderia automatizada, que dispensa a contratação de funcionários. Da mesma forma, também há casos em que a organização é feita somente com o auxílio de pessoal, sem o emprego de instrumentos materiais ${ }^{34}$.

Não se pode afirmar que o requisito da atividade organizada deixa de existir em alguns casos. Na verdade, o que ocorre é que o conceito de atividade organizada é diverso de acordo com os diferentes tipos de empresa e também de acordo com os diferentes objetos sobre os quais recaem a atividade intermediária da empresa. Por exemplo, numa

\footnotetext{
${ }^{30}$ Cf. BUONOCORE, Vincenzo. op. cit., p. 99-107.

${ }^{31}$ Cf. BORBA, José Edwaldo Tavares. Direito societário. 11. ed. Rio de Janeiro: Renovar, 2008. p. 17.

${ }^{32}$ As controvérsias doutrinárias acerca do estabelecimento virtual não serão objeto da presente dissertação.

${ }^{33}$ Cf. MARCONDES, Sylvio. Problemas de direito mercantil, cit., p. 141.

${ }^{34}$ Cf. BUONOCORE, Vincenzo. op. cit., p. 111-119, 125-126.
} 
empresa industrial, em que a função intermediária está diretamente relacionada ao mercado de trabalho, a organização exigida seria tipicamente uma organização do trabalho alheio. Já numa empresa comercial em sentido estrito, por outro lado, passa a ser relavante a organização dos atos ínsita à função intermediária de trocas, de modo que, em tais tipos de empresa, a organização do trabalho alheio assume somente uma função instrumental, secundária. O termo utilizado pelo legislador deveria adquirir uma interpretação diferenciada, a depender do objeto e da dimensão da empresa, portanto. Vale lembrar, porém, que um mínimo de organização sempre é necessário para que seja possível distinguir o pequeno empresário do trabalhador autônomo ${ }^{35}$.

De acordo com o parágrafo único do art. 966 do Código Civil, os profissionais liberais, cientistas, escritores e artistas não são empresários, exceto se suas atividades constituírem "elemento de empresa". Não há, contudo, uma definição legal do que seria considerado "elemento de empresa", de forma que tal definição será fruto de interpretação doutrinária e jurisprudencial, caso a caso, tratando-se de um critério subjetivo.

Muitos autores defendem que o principal "elemento de empresa" é a organização do trabalho. O empresário poderia ser distinguido do profissional autônomo em função da existência de "organização" na realização do labor, caracterizada pela articulação do trabalho alheio e dos meios materiais, ainda que tal organização seja de pequena monta ${ }^{36}$.

A título ilustrativo, poderíamos dizer que não é empresário, por exemplo, o engenheiro que executa projetos individualmente, mas aquele que se organiza para exercer sua atividade, criando diversos departamentos em seu escritório, contratando empregados e passando a comandar essa organização será considerado empresário, pois sua própria atividade estará incluída dentro de um conjunto. Nesse segundo caso, o elemento de empresa ficará caracterizado quando os clientes passarem a confiar na estrutura organizacional oferecida, independentemente de quem executará o projeto na prática, não havendo mais uma atividade personalíssima, vinculada ao engenheiro original.

Para tais autores, portanto, empresa é a atividade econômica organizada, e o empresário é o agente dessa atividade, seja este uma pessoa natural ou uma pessoa

\footnotetext{
${ }^{35}$ Cf. BUONOCORE, Vincenzo. op. cit., p. 111-119, 125-126.

${ }^{36} \mathrm{Cf}$. BORBA, José Edwaldo Tavares. op. cit., p. 15-16.
} 
jurídica $^{37}$; é quem organiza e dirige a empresa, reunindo e coordenando os fatores de produção $^{38}$.

Em alguns casos, ainda, o "elemento de empresa" pode ser evidenciado quando a entidade em questão participa ou é parte de outra atividade que é empresarial, pelos critérios acima analisados. É o caso típico das sociedades holdings puras, por exemplo, que têm por objeto único controlar outras sociedades. Durante muito tempo o caráter empresarial de tais sociedades foi questionado, mas, atualmente, tal discussão está praticamente superada, entendendo a corrente majoritária que tais sociedades são empresárias sempre que a(s) sociedade(s) controlada(s) for(em) empresária(s) ${ }^{39}$.

Por fim, vale ressaltar que o Código Civil inclui dentro da finalidade específica almejada pelo empresário não apenas a industrialização ou manufatura (produção de bens ou serviços), mas também a intermediação (circulação de bens ou serviços).

A definição do atual Código Civil, portanto, é mais abrangente que a antiga definição de comerciante, atingindo um número maior de atividades econômicas, uma vez que inclui a circulação ou produção de serviços, que antes ficavam adstritas às sociedades civis. Assim, com a entrada em vigor do novo código, a prestação de serviços passa a estar submetida às regras do direito empresarial, desde que estes sejam prestados de forma profissional (habitual), por meio de uma atividade organizada.

Hoje em dia, portanto, faz muito mais sentido falar-se em direito da empresa ou direito empresarial, ao invés de direito comercial, não só porque o conceito de empresário é mais abrangente que o de comerciante, mas também porque o próprio Código Civil atual passou a adotar a Teoria da Empresa. Assim, essa será a nomenclatura utilizada no presente estudo nos próximos capítulos.

\subsubsection{Crítica ao conceito de profissionalismo}

Como vista acima, o conceito de profissionalismo estabelecido no art. 966 do Código Civil requer a presença de alguns requisitos, estudados no item anterior, conceito que passaremos a chamar de "profissionalismo stricto sensu". É comum, porém, notar o

\footnotetext{
${ }^{37}$ Cf. BORBA, José Edwaldo Tavares. op. cit., p. 15.

${ }^{38}$ Cf. MARCONDES, Sylvio. Problemas de direito mercantil, cit., p. 5.

${ }^{39}$ Cf. BUONOCORE, Vincenzo. op. cit., p. 67-71.
} 
uso do termo "profissionalismo" em um sentido menos técnico, para designar o exercício de alguma atividade especializada, que supõe um preparo prévio, ao que se passa denominar de "profissionalismo lato sensu".

Embora não haja a pretensão de que o legislador brasileiro tivesse estabelecido no próprio código diferentes graus de profissionalismo, não se pode olvidar que, para fins de aplicação das regras do CDC, bem como para a caracterização da dependência econômica, é muito comum a utilização do termo "profissionalismo" em seu sentido lato. Assim, tal distinção, se não presente na legislação, deveria partir da doutrina e, especialmente, da jurisprudência.

Tal não vem ocorrendo com muita freqüência, contudo. Correntemente, encontramse passagens doutrinárias ou trechos de acórdãos - que serão citados ao longo do presente trabalho - excluindo a aplicação das regras do CDC ou descaracterizando a dependência econômica pelo simples fato de ambas as partes da relação negocial serem "profissionais".

Tem-se deixado de lado, porém, que todo e qualquer empresário em algum momento teve que dar início a sua experiência como tal, sendo impossível comparar a vivência no mercado de um grande franqueador com a de um franqueado que se encontra em sua primeira experiência empresarial, só para citar um exemplo.

Nesse passo, acredita-se ser plenamente possível a caracterização da dependência econômica ou da vulnerabilidade, para fins de aplicação do CDC, na relação entre dois empresários, como se verá a seguir, especialmente quando, no caso concreto, o "profissionalismo" (aqui, em seu sentido lato) de ambos for muito díspare, como no exemplo acima $^{40}$. Entretanto, a efetiva incidência de tal diploma legal, nunca é demais lembrar, somente deverá ocorrer quando os institutos de direito civil e a tutela concorrencial se mostrarem insuficientes no caso concreto.

\footnotetext{
${ }^{40}$ Tratar de forma desigual aqueles que, efetivamente, são desiguais, reforça o próprio princípio da igualdade. COLLINS leciona que "the modern law replaces the commitment to formal equality by a recognition that each person enters the market from a different situation, and that to ignore those differences in knowledge, expertise, needs and command over resources is not to treat people equally but to treat unlike cases alike" (COLLINS, Hugh. The law of contract. 3. ed. London: Butterworths, 1997. p. 31).
} 


\section{DEFINIÇÃO DE CONSUMIDOR}

$\mathrm{O}$ sistema consumerista brasileiro tem embasamento constitucional. $\mathrm{O}$ art. $5^{\circ}$ da Constituição Federal de 1988 estabelece como direito fundamental do brasileiro a defesa dos seus direitos como consumidor. O art. 170, por sua vez, determina que a ordem constitucional econômica do nosso mercado será baseada na livre iniciativa (caput), mas limitada pelos direitos do consumidor (inciso V). Finalmente, o art. 48 do Ato das Disposições Constitucionais Transitórias - ADCT exige a elaboração de um sistema protetivo em forma de código ${ }^{41}$.

Como será abordado um pouco mais adiante, a pedra de toque do CDC é justamente identificar quem é o sujeito de direitos especial escolhido para receber um microssistema tutelar legal, daí porque a definição de consumidor, no direito brasileiro, se faz ainda mais relevante ${ }^{42}$. Não é à toa que a própria Constituição Federal de 1988 faz menção ao sujeito de direitos - o consumidor - e não ao mercado de consumo.

A complexidade do sistema consumerista brasileiro, contudo, começa exatamente na definição dos sujeitos de direitos. O conceito de consumidor, por exemplo, está esparso por diversos dispositivos do CDC (art. 2º caput e parágrafo único, art. 17 e art. 29), conforme será estudado nas próximas páginas, sendo que tal definição leva em conta não apenas a ótica individual, mas também a transindividual ou de grupo.

Também o conceito de fornecedor, ainda que muito menos complexo e contraditório que o de consumidor, pode dar margem a algumas dúvidas, as quais não serão, contudo, objeto da presente análise. Segundo o art. $3^{\circ}$ do CDC, fornecedor "é toda pessoa física ou jurídica, pública ou privada, nacional ou estrangeira, bem como os entes despersonalizados, que desenvolvem atividade e produção, montagem, criação, construção, transformação, importação, exportação, distribuição ou comercialização de produtos ou prestação de serviços".

A própria relação de consumo, não definida no CDC, depende em grande parte da definição dos sujeitos de direitos, já que esta é entendida, em sede doutrinária e

\footnotetext{
${ }^{41}$ Cf. MARQUES, Cláudia Lima. Superação das antinomias pelo diálogo das fontes: o modelo brasileiro de coexistência entre o Código de Defesa do Consumidor e o Código Civil de 2002. Revista de Direito do Consumidor, São Paulo, v. 13, n. 51, p. 51, jul./set. 2004.

${ }^{42}$ Cf. Id., loc. cit.
} 
jurisprudencial, como a relação jurídica existente entre fornecedor e consumidor, tendo como objeto a aquisição de produtos ou utilização de serviços pelo consumidor ${ }^{43}$.

Antes de se adentrar propriamente no conceito jurídico de consumidor, no entanto, convém lembrar que há outros campos do conhecimento humano que também trazem uma visão sobre o termo "consumidor".

Etimologicamente, a palavra "consumir", de acordo com a conclusão de DE LUCCA, deriva de consumere, no sentido de fazer desaparecer pelo uso ou pelo gasto, gastar, destruir, desfazer, despender, absorver, corroer ${ }^{44}$.

Do ponto de vista econômico, consumidor é quem pratica o ato pelo qual se completa a última etapa do processo econômico ${ }^{45}$. Conforme abordaremos a seguir, o conceito de consumidor stricto sensu adotado pelo CDC está intimamente relacionado ao conceito econômico para aqueles que interpretam finalisticamente tal código.

Sob o ângulo da Sociologia, nas palavras de José GERALDO BRITO, é possível definir consumidor como “(...) qualquer indivíduo que frui ou se utiliza de bens e serviços, mas pertencente a uma determinada categoria ou classe social" ${ }^{\prime 46}$. É nesse ponto que o movimento consumerista e o trabalhista se interpenetram. O pleito trabalhista por melhores condições de vida está usualmente relacionado ao poder aquisitivo dos trabalhadores para adquirir produtos e/ou contratar serviços em maior escala e de melhor qualidade ${ }^{47}$. O consumo, assim, acaba servindo também como um método de divisão de classes sociais, proporcionando status aos consumidores.

Também para a Psicologia não escapou o conceito de consumidor, sendo este considerado o sujeito sobre o qual se estudam as reações e as motivações internas que levam ao consumo, como forma de se individualizar os critérios para a produção e se estabelecer o público-alvo de cada produto ou serviço. Tal sujeito, portanto, é o foco da atenção dos profissionais de marketing e de publicidade ${ }^{48}$.

Finalmente, vale lembrar o sentido filosófico da palavra "consumidor", também relacionado ao plano espiritual do ser humano. Segundo definição de REICH, consumidor é

\footnotetext{
${ }^{43}$ Cf. NERY JUNIOR, Nelson et al. Código Brasileiro de Defesa do Consumidor comentado pelos autores do Anteprojeto. 4. ed. Rio de Janeiro: Forense Universitária, 1995. p. 283.

${ }^{44}$ Cf. DE LUCCA, Newton. Direito do consumidor. 2. ed. São Paulo: Quartier Latin, 2008. p. 112.

${ }^{45}$ Cf.b Id. Ibid., p. 113.

${ }^{46}$ FILOMENO, José Geraldo Brito. Manual de direitos do consumidor. São Paulo: Atlas, 1991. p. 24.

${ }^{47}$ Cf. Id. Ibid., p. 24-25.

${ }^{48}$ Cf. Id. Ibid., p. 24.
} 
"aquele que, pela alienação de sua força de trabalho, obtém o rendimento de que necessita para reprodução da sua atividade material e espiritual"49. O sentido filosófico em muito se relaciona com o psicológico, pois, na medida em que o consumo representa status na sociedade atual, os seres humanos passam a se preocupar demasiadamente com as questões materiais da vida, deixando de lado a formação humanista. Tal ideologia fornece a base sobre a qual se sustenta o mundo capitalista moderno, onde os indivíduos são rebaixados à categoria de objeto, preocupados unicamente em despertar a admiração e a inveja alheias.

Feitas tais considerações, passa-se a abordar o conceito jurídico de consumidor.

\subsection{Consumidor stricto sensu}

Nota-se a existência de dois tipos de conceito jurídico de consumidor no direito comparado: um subjetivo e outro objetivo.

O conceito jurídico objetivo, existente, por exemplo, no México ${ }^{50}$, ressalta o aspecto de retirada do bem e/ou serviço adquirido pelo agente econômico do mercado, destruindo o seu valor de troca. Tal concepção está preocupada com o ato de consumo praticado, sendo irrelevante quem adquire o produto ou utiliza o serviço. Dessa forma, aponta BOURGOIGNIE:

"permite incluir no campo das preocupações do direito do consumo os profissionais, industriais, comerciantes ou prestadores de serviços que adquirem, para as necessidades de suas empresas, bens de capital e até mesmo de investimento" ${ }^{\text {. }}$.

Já o conceito subjetivo, que é adotado na maioria dos países europeus ${ }^{52}$, enfatiza a qualidade de não profissional do consumidor em relação ao fornecedor e foca,

\footnotetext{
${ }^{49}$ REICH apud DE LUCCA, Newton. op. cit., p. 120.

${ }^{50} \mathrm{O}$ art. $3^{\circ}$ da lei mexicana de 1975 estabele que será considerado consumidor "quem contrata para sua utilização a aquisição, o uso ou desfrute de bens ou a prestação de um serviço".

${ }^{51}$ BouRGOIGNIE apud DE LUCCA, Newton. op. cit., p. 132.

${ }^{52} \mathrm{O}$ art. $2^{\circ}$ da lei portuguesa $\mathrm{n}^{\circ} .29$ de 1981 determina que: "considera-se consumidor todo aquele a que sejam fornecidos bens ou serviços destinados ao seu uso privado por pessoa singular ou colectiva que exerça, com carácter profissional, uma atividade económica". Da mesma forma, o art. $1^{\circ}$ da lei sueca de 1973 define como consumidor "a pessoa privada que compra de um comerciante uma mercadoria principalmente destinada ao seu uso privativo e que é vendida no âmbito da atividade profissional do comerciante". O projeto do Código de Consumo francês, em seu art. L.3, ainda, estabelecia que "les consommateurs sont les personnes physiques ou morales de droit privé qui se procurent ou qui utilisent des biens ou des services pour um usage non professionnel', mas a própria doutrina francesa criticava
} 
primordialmente, as pessoas físicas ${ }^{53}$. Tal conceito permite identificar as vulnerabilidades e necessidades do grupo sócio-econômico representado pela figura do consumidor no contexto do ciclo econômico, o qual abrange a produção, a distribuição, as trocas e o consumo, para determinar que somente aquele que efetivamente faz cessar toda atividade de produção, transformação e/ou distribuição é que pode ser considerado consumidor. $\mathrm{O}$ critério é baseado na diferença de qualidade entre as partes envolvidas ${ }^{54}$.

A grande dificuldade dos legisladores, especialmente nos países que adotam o conceito subjetivo e estendem a proteção consumerista somente às pessoas físicas, diz respeito à proteção das pequenas empresas. Sob vários aspectos, as pequenas empresas estão na mesma posição que as pessoas físicas, não tendo expertise em diversos ramos, e, portanto, mereceriam igualmente uma proteção especial. O grande problema é estabelecer a linha de divisão entre aquelas empresas que merecem a tutela consumerista e aquelas que não merecem. Qual deveria ser o critério utilizado: o número de empregados da empresa, o numero de ativos, seu patrimônio líquido? Enfim, muitos ordenamentos tentaram, em vão, definir um critério puramente objetivo ${ }^{55}$.

O conceito de consumidor stricto sensu - previsto no art. $2^{\circ}$, caput, do CDC determina que "consumidor é toda pessoa física ou jurídica que adquire ou utiliza produto ou serviço como destinatário final".

Ao contrário de alguns países europeus, que excluem totalmente do âmbito de proteção das normas consumeristas as pessoas jurídicas, o legislador brasileiro preferiu adotar um conceito misto, que inclui também as pessoas jurídicas, mas não chega a ser puramente um conceito objetivo.

Assim, no ordenamento brasileiro, o consumidor não é definido necessariamente como um leigo ou um não profissional que contrata ou se relaciona com um profissional para fins familiares ou de suas necessidades de vida (sem fito de lucro), mas sim aquele que adquire ou utiliza um bem como destinatário final ${ }^{56}$, o que, numa primeira leitura,

veementemente a inclusão das pessoas jurídicas em tal artigo. Finalmente, o art. $2^{\circ}$ da Diretiva 93/13/CEE entende por consumidor "toute personne physique qui, dans les contrats relevant de la présente directive, agit à des fins qui n'entrent pas dans le cadre de son activité professionnelle".

${ }^{53}$ Cf. DE LUCCA, Newton. op. cit., p. 129.

${ }^{54}$ Cf. Id. Ibid., p. 135.

${ }^{55} \mathrm{Cf}$. HONDIUS, Ewoud. The notion of consumer: European Union versus Member States. Sydney Law Review, v. 28, p. 95-96, 2006.

${ }^{56}$ Cf. MARQUES, Cláudia Lima. Campo de aplicação do CDC. In: BENJAMIN, Antônio Herman V.; MARQUES, Cláudia Lima; BESSA, Leonardo Roscoe. Manual de direito do consumidor. São Paulo: Ed. Revista dos Tribunais, 2008. p. 68. 
poderia levar alguns a acreditar que a intenção do legislador foi a de se aproximar do conceito objetivo acima abordado. Todavia, o CDC não define o conceito de "destinatário final", o que acabou dando margem ao surgimento de diversas teorias ávidas por conferir a melhor interpretação a tal expressão, as quais passa-se a explicar a seguir.

\subsubsection{Teoria Finalista Clássica}

A Teoria Finalista Clássica se aproxima muito mais do conceito subjetivo existente principalmente nos países europeus, defendendo uma aplicação mais restrita do CDC. Para tal teoria, consumidor seria somente aquele que efetivamente retira o bem ou serviço do mercado, utilizando-o para fins pessoais ${ }^{57}$. Exige, dessa forma, que o consumidor, ainda que pessoa jurídica, seja destinatário fático e econômico do bem ${ }^{58}$. Tal seria a melhor interpretação para o termo “destinatário final”, segundo a opinião dos adeptos dessa teoria.

Para os finalistas, o objetivo de restringir a figura do consumidor é justamente conferir maior proteção àqueles que são realmente vulneráveis, necessitando de proteção especial $^{59}$. Atribuir maior campo de abrangência na aplicação do CDC acabaria por desvirtuar a lógica do sistema, em desrespeito aos princípios básicos esculpidos nos arts. $4^{\circ}$ e $6^{\circ}$ desse código, uma vez que a jurisprudência passaria a se pautar não apenas em casos

\footnotetext{
${ }^{57}$ Segundo BENJAMIN, “(...) consumidor é todo aquele que, para seu uso pessoal, de sua família, ou dos que se subordinam por vinculação doméstica ou protetiva a ele, adquire ou utiliza produtos, serviços ou quaisquer outros bens ou informação colocados a sua disposição por comerciantes ou por qualquer outra pessoa natural ou jurídica, no curso de sua atividade ou conhecimento profissionais" (BENJAMIN, Antônio Herman V. O conceito jurídico de consumidor. Revista dos Tribunais, São Paulo, v. 77, n. 628, p. 78, fev. 1988).

${ }^{58}$ É caracterizado como destinatário fático aquele que retira o bem ou serviço do mercado. Já o destinatário econômico é aquele que adquire um bem ou serviço para fins pessoais (uso próprio e de sua família), sem qualquer objetivo profissional. CLÁUDIA LIMA MARQUES explica que "o destinatário final é o Endverbraucher, o consumidor final, o que retira o bem do mercado ao adquirir ou simplesmente utilizá-lo (destinatário final fático), aquele que coloca um fim na cadeia de produção (destinatário final econômico) e não aquele que utiliza o bem para continuar a produzir, pois ele não é o consumidor final, ele está transformando o bem, utilizando o bem, incluindo o serviço contratado no seu, para oferecê-lo, por sua vez, ao seu cliente, seu consumidor (...)" (MARQUES, Cláudia Lima. Relações de consumo na pósmodernidade: em defesa de uma interpretação finalista dos Artigos $2^{\circ}$ e 29 do CDC. Revista da Faculdade de Direito da Universidade Federal do Rio Grande do Sul, Porto Alegre, v. 19, p. 111, 2001).

${ }^{59}$ BENJAMIN chega à conclusão de que "(...) a amplitude de uma definição de consumidor que inclua a pessoa jurídica entre seus tutelados - e sem qualquer ressalva - pode-se transformar em óbice ao desenvolvimento do Direito do Consumidor, na medida em que tal conceito jurídico de consumidor quase que chega a se confundir com o seu similar econômico (excluindo-se deste último, evidentemente, o consumidor intermediário). Em outras palavras: se todos somos consumidores (no sentido jurídico), inclusive as empresas produtoras, por que, então, tutelar-se, de modo especial, o consumidor? Também tem sido apontado na doutrina majoritária estrangeira que tão amplo conceito, de certo modo, desvia a finalidade do Direito do Consumidor, que é proteger a parte mais fraca e inexperiente na relação de consumo" (BENJAMIN, Antônio Herman V. op. cit., p. 77-78).
} 
de extrema vulnerabilidade, mas também em situações nas quais profissionais estivessem apenas reclamando mais benesses do que o direito comercial já lhes concede ${ }^{60}$.

Tal teoria, portanto, exclui do âmbito de aplicação do CDC todos os contratos concluídos entre dois profissionais, não aceitando a aplicação do código ao consumo intermédio, caracterizado este quando uma pessoa física ou jurídica adquire o bem para uso profissional e/ou para revenda ${ }^{61}$ e 62 , pois, nessa hipótese, as cadeias de produção e/ou de distribuição não são encerradas, servindo o bem como um instrumento de produção, cujo preço será embutido no preço final oferecido, aí sim, ao consumidor destinatário econômico do bem ${ }^{63}$ e 64 .

Como bem aponta CláUdia Lima MARQUeS, tratar os iguais (profissionais) como se diferentes (e fracos) fossem, em linha com o que a Teoria Maximalista defende, conforme se verá a seguir, acaba por ferir o princípio da igualdade, da dignidade da pessoa humana e o princípio imanente da justiça social. Segundo a autora, o Código Civil seria suficiente para conferir um tratamento justo e equitativo às relações interempresariais ${ }^{65}$. A

${ }^{60}$ Cf. MARQUES, Cláudia Lima. Campo de aplicação do CDC, cit., p. 68-69.

${ }^{61}$ Cf. MUSSI, Luiz Daniel Rodrigues Haj. op. cit., p. 49. São vários os autores que ainda mantêm uma posição mais conservadora em relação à aplicação do CDC aos contratos interempresariais, em linha com o que propugna a Teoria Finalista Clássica, como, por exemplo, ARNOLDO WALD e KAZUO WATANABE (WALD, Arnoldo. O direito do consumidor e suas repercussões em relação às instituições financeiras. Revista dos Tribunais, São Paulo, v. 80, n. 666. p. 14, abr. 1991; e WATANABE, Kazuo et al. Código Brasileiro de Defesa do Consumidor comentado pelos autores do anteprojeto. 6. ed. Rio de Janeiro: Forense Universitária, 1999. p. 27).

${ }^{62}$ Parte da doutrina francesa também entende que a aquisição para revenda não deve ser protegida pelas normas consumeristas, conforme se pode notar da explicação de CALAIS-AULOY: "l'acte de consommation s'oppose à l'acte que j'appellerai, pour simplifier, acte professionnel, et qui est accompli pour les besoins d'une entreprise, d'une exploitation ou d'une profession. Acheter pour revendre n'est évidemment pas um acte de consommation" (CALAIS-AULOY apud DE LUCCA, Newton. op. cit., p. 126). Já no direito alemão, ainda que, de um modo geral, as normas consumeristas também não sejam aplicáveis ao consumo intermédio, aceita-se, em alguns casos, a aplicação de textos legais relativos ao consumo de bens na hipótese em que uma empresa tenha adquirido o bem para revenda ou para utilização em sua atividade produtiva (vide nota de rodapé $\mathrm{n}^{\circ} .303 \mathrm{em}$ DE LUCCA, Newton. op. cit., p. 127).

${ }^{63}$ Cf. MARQUES, Cláudia Lima. Campo de aplicação do CDC, cit., p. 69.

${ }^{64}$ Nesse mesmo sentido, DE LUCCA aponta que "em que pese a larga controvérsia existente a respeito, tanto aqui no Brasil como nos vários diplomas alienígenas, no tocante à fixação de um conceito jurídico preciso e unitário de consumidor, o legislador nacional optou, definitivamente, por afastar da proteção que ele instituiu em favor dos consumidores, o chamado consumo intermediário, vale dizer, aquele que é utilizado pelas empresas dos bens e serviços necessários para o processo produtivo, consoante consagrada definição existente sobre a matéria" (DE LUCCA, Newton. op. cit., p. 125). CARLOS FERREIRA DE ALMEIDA também defende a inaplicabilidade do CDC ao consumo intermédio, alegando que "o consumidor é um não-profissional ou quem como tal actua, isto é, fora do âmbito de sua atividade profissional. Daí que se conclua que o chamado 'consumo intermédio', em que o utilizador é uma empresa ou um profissional, não é consumo em sentido jurídico" (CARlos FerreIrA DE ALMEIDA apud DE LUCCA, Newton. op. cit., p. 126).

${ }^{65}$ Cf. MARQUES, Cláudia Lima. Superação das antinomias pelo diálogo das fontes: o modelo brasileiro de coexistência entre o Código de Defesa do Consumidor e o Código Civil de 2002, cit., p. 51. 
própria jurista, porém, aceita, de modo excepcional, a aplicação do CDC a relações entre empresários sempre que se puder equiparar um deles a consumidor ${ }^{66}$.

\subsubsection{Teoria Maximalista}

Para os maximalistas, por outro lado, o CDC deveria ser visto como um regulamento do mercado de consumo brasileiro, um código geral sobre o consumo, e sua aplicação deveria ser a mais extensa possível, de forma a abranger o maior número de relações protegidas por um código muito mais benéfico para a sociedade.

Para esta teoria, portanto, a interpretação do art. $2^{\circ}$ do CDC deve ser totalmente objetiva, especialmente porque se fosse a intenção do legislador limitar o campo de aplicação do código que estava criando, tais restrições estariam expressas no texto legal ${ }^{67}$.

A expressão "destinatário final" do referido art. $2^{\circ}$, assim, deve ser lida como destinatário fático, não importando se a pessoa física ou jurídica que retira o bem ou serviço do mercado tem ou não fito de lucro ao utilizar o bem ou serviço que adquiriu ${ }^{68}$.

Segundo os maximalistas, a constatação da vulnerabilidade no caso concreto não é relevante. Aliás, o simples uso de um método contratual massificado, como o contrato de adesão, já seria suficiente para presumir a vulnerabilidade do aderente. Ademais, o consumo intermédio, ao contrário do que propõe a Teoria Finalista Clássica, estaria também protegido pelas normas do CDC.

\footnotetext{
${ }^{66}$ Cf. MARQUES, Cláudia Lima. Superação das antinomias pelo diálogo das fontes: o modelo brasileiro de coexistência entre o Código de Defesa do Consumidor e o Código Civil de 2002, cit., p. 51.

${ }^{67}$ Esse é o entendimento esboçado no Código de Defesa do Consumidor comentado por J. M. ARRUDA Alvim, ThereZA Alvim, EDUARdo ARrudA Alvim e JAYME MARINS, a saber: "Procurou traçar o legislador, objetivamente, a linha mestra do conceito de consumidor. Neste mister, estabeleceu no artigo $2^{\circ}$ deste Código que é consumidor 'toda pessoa física ou jurídica que adquire ou utiliza produto ou serviço como destinatário final', ou seja, cuja aquisição se insere no termo final dos quadros de um ciclo de produção. (...) De nossa parte, não podemos concordar com a equiparação que se quer fazer de uso final com uso privado, pois tal equiparação não está autorizada na lei e não cabe ao intérprete restringir onde a norma não o faz. (...) Da mesma forma, não se pode pretender limitar a proteção do Código às pessoas jurídicas equiparadas ao consumidor hipossuficiente, pois que em momento algum condiciona o Código o conceito de consumidor à hipossuficiência. (...). Logo a única característica restritiva seria a aquisição ou utilização do bem como destinatário final. Assim, para o art. $2^{\circ}$, o importante é a retirada do bem de mercado (ato objetivo) sem se importar com o sujeito que adquire o bem, profissional ou não (elemento subjetivo)" (ALVIM, J. M. Arruda; ALVIM, Thereza; ALVIM, Eduardo Arruda; MARINS, Jayme. Código do Consumidor Comentado. 2. ed. São Paulo: Ed. Revista dos Tribunais, 1995. p. 18-31).

${ }^{68}$ Dentre os autores que também defendem a corrente maximalista, pode-se citar JOSÉ GERALDO BRITO Filomeno, Antonio Carlos Efing e Marcio Mello CaSAdo.
} 
Dentre os autores que defendem a aplicação do CDC ao consumo intermédio, vale apontar a lição de CAVALIERI FILHO, segundo o qual:

\begin{abstract}
“(...) não há como negar que bens e serviços utilizados no chamado consumo intermediário situam-se na última etapa do processo produtivo, pois são retirados de circulação para o uso privado da empresa, caso em que não age como fornecedora, nem como produtora ou intermediária. Embora os custos desses bens e serviços sejam repassados ao público, não estão, todavia, destinados ao consumidor. Seu custo é repassado ao consumidor, mas a sua utilidade não"69.
\end{abstract}

A principal crítica que se faz a esta teoria é que ela acaba transformando o CDC em Direito Privado geral, na medida em que praticamente todos os profissionais consomem de forma intermediária insumos para a sua atividade-fim, de modo que a regulação dos contratos interempresariais pelo Código Civil acabaria por se tornar inútil ${ }^{70}$.

CRISTIANO ZANETTI lembra que o CDC é diploma setorial, destinado a proteger somente as partes vulneráveis no mercado. Assim, a leitura maximalista do CDC, que não se preocupa com a comprovação da vulnerabilidade no caso concreto, conduziria, no final, a aplicá-lo como verdadeira lei geral e, como conseqüência, desnaturaria o sistema especial de proteção que tal diploma legal procura instaurar. Para o autor, o consumidor tende a identificar-se com a pessoa física e a extensão do regramento consumerista às pessoas jurídicas somente deveria ser feita a título excepcional e, em hipótese alguma, quando estas estiverem no exercício de suas atividades profissionais ${ }^{71}$.

A crítica à Teoria Maximalista, contudo, não deveria estar relacionada à pessoa jurídica enquanto consumidora, uma vez que o próprio art. $2^{\circ}$ menciona expressamente que consumidor é toda pessoa física ou jurídica que utiliza produto ou serviço como destinatário final. Nada impede, portanto, como aponta ANTONIO CARLOS MORATO, que uma grande corporação utilize em seu favor o CDC quando destinatária final de produto ou serviço $^{72}$. A crítica à teoria ganha relevo somente no que diz respeito ao conceito de destinatário final enquanto mero destinatário fático, independentemente da comprovação de vulnerabilidade no caso concreto.

\footnotetext{
${ }^{69}$ CAVALIERI FILHO, Sérgio. Programa de responsabilidade civil. 4. ed. São Paulo: Malheiros Ed., 2003. p. 467.

${ }^{70}$ Cf. MARQUES, Cláudia Lima. Campo de aplicação do CDC, cit., p. 70.

${ }^{71}$ Cf. ZANETTI, Cristiano de Sousa. Direito contratual contemporâneo: a liberdade contratual e sua fragmentação. São Paulo: Método, 2008. p. 213-214.

${ }^{72}$ Cf. MORATO, Antonio Carlos. Pessoa jurídica consumidora. São Paulo: Ed. Revista dos Tribunais, 2008. p. 26.
} 
Assim como a extrema flexibilidade atribuída ao conceito de consumidor pela Teoria Maximalista pode acabar fazendo com que o CDC seja aplicado a todo e qualquer contrato firmado por uma pessoa jurídica, tornando-se, portanto, lei geral, o rigor de alguns finalistas, que entendem que a pessoa jurídica somente seria consumidora quando adquiresse produto ou utilizasse serviço que não fosse considerado insumo para sua atividade empresarial, pode acabar até mesmo negando a vigência do art. $2^{\circ}$ do CDC, já que praticamente nunca uma pessoa jurídica seria considerada consumidora.

Como muito bem apontado por RiZZATo NunES, a pessoa jurídica não come, não bebe, não dorme, não viaja, não lê, não vai ao cinema, não assiste à aula, não vai a shows, não aluga filmes, não vê publicidade etc. Logo, para ser consumidora, como o próprio art. $2^{\circ}$ do CDC preconiza, é inevitável que sejam considerados os bens e serviços tecnicamente possíveis de serem adquiridos por uma pessoa jurídica e que lhe sirvam como bens de produção e, simultaneamente, bens de consumo ${ }^{73}$.

\subsubsection{Teoria Finalista Aprofundada}

Com a evolução da doutrina e jurisprudência pátrias, especialmente após o advento do Código Civil de 2002, passou-se a notar que a aplicação de qualquer uma das teorias acima analisadas poderia trazer prejuízos aos objetivos almejados pelo CDC.

Tal evolução culminou no que podemos chamar de "Teoria Finalista Aprofundada"74 ou "Teoria Finalista Mitigada", como preferem alguns, a qual define o consumidor com base em um conceito finalista, mas abre uma exceção à aplicação do CDC a sujeitos que não sejam destinatários econômicos do produto ou serviço adquirido, mediante a comprovação expressa de sua vulnerabilidade ${ }^{75}$.

\footnotetext{
${ }^{73}$ NUNES, Luiz Antonio Rizzato. Curso de direito do consumidor. 2. ed. São Paulo: Saraiva, 2005. p. 80.

${ }^{74}$ Já em 2005, ClÁUDIA LIMA MARQUES sinalizava para tal tendência, conforme é possível notar do trecho a seguir: "Desde a entrada em vigor do CC/2002, parece-me crescer uma tendência nova na jurisprudência, concentrada na noção de consumidor final imediato (Endverbraucher) e de vulnerabilidade (art. $4^{o}$, I), que poderíamos denominar finalismo aprofundado." (MARQUES, Cláudia Lima. Contratos no Código de Defesa do Consumidor. 5. ed. São Paulo: Ed. Revista dos Tribunais, 2005. p. 347).

${ }^{75}$ TARTUCE, por exemplo, embora se denomine finalista, afirma que em algumas situações a Teoria Maximalista seria justificável, como no caso de contratos de adesão em que a vulnerabilidade de uma das partes é patente. Embora tal autor não tenha usado a terminologia mais recente, fica claro que, na verdade, a teoria a que é adepto não é a Finalista Clássica, mas sim a Finalista Aprofundada (Cf. TARTUCE, Flavio. Função social dos contratos: do Código de Defesa do Consumidor ao Código Civil de 2002. 2. ed. São Paulo: Ed. Método, 2007. p. 309-310).
} 
A vulnerabilidade pode ser definida, segundo CláUdiA LIMA MARQUES, como:

“(...) uma situação permanente ou provisória, individual ou coletiva, que fragiliza, enfraquece o sujeito de direitos, desequilibrando a relação de consumo. Vulnerabilidade é uma característica, um estado do sujeito mais fraco, um sinal de necessidade de proteção"76.

PAUlO VALÉRIO, ainda, aponta diversas formas de submeter o consumidor a uma situação de vulnerabilidade, tais como o tecnicismo, a complexidade, a generalidade, a extensão e/ou a dimensão dos caracteres dos contratos, a remissão a documentos não entregues, a utilização de conceitos vagos e indeterminados, a complexidade de produtos e serviços inéditos como a Internet, por exemplo, o regime de monopólio etc. ${ }^{77}$.

No caso dos empresários, parte da doutrina exige, ainda, além da comprovação da vulnerabilidade, que estes estejam agindo fora do campo de sua especialidade, de sua atividade-fim, para que possam ser beneficiados pelas normas do $\mathrm{CDC}^{78}$. Tal requisito, contudo, somente faz sentido para a aplicação do art. $2^{\circ}$, caput, do $\mathrm{CDC}$, e não para o conceito de consumidor equiparado, que será abordado a seguir, pois, do contrário, acabaria por fazer a Teoria Finalista Aprofundada regredir praticamente ao conceito original da Teoria Finalista Clássica. Assim, embora quando se está tratando da definição do consumidor stricto sensu, estender a aplicação do CDC ao consumo intermédio possa parecer excessivo, tal não parece ocorrer no caso do consumidor por equiparação do art. 29 do CDC.

Esse parece ser o entendimento mais acertado, a fim de se evitar que o CDC se torne norma geral, trazendo por terra os objetivos de sua criação, mas, ao mesmo tempo, conferindo proteção aos empresários que estejam sujeitos a uma situação de abuso de dependência econômica.

\subsubsection{Caracterização da vulnerabilidade}

A doutrina aponta a existência de três tipos de vulnerabilidade, a saber: (i) a técnica; (ii) a científica (incluindo a jurídica); e (iii) a fática (ou sócio-econômica).

\footnotetext{
${ }^{76}$ MARQUES, Cláudia Lima. Campo de aplicação do CDC, cit., p. 71.

${ }^{77}$ Cf. MORAES, Paulo Valério Dal Pai. O Código de Defesa do Consumidor: princípio da vulnerabilidade no contrato, na publicidade, nas demais práticas comerciais. Porto Alegre: Síntese, 1999. p. 115.

${ }^{78}$ Nesse sentido, vide: MUSSI, Luiz Daniel Rodrigues Haj. op. cit., p. 49; GUYON, Yves. Droit du marché et droit commun des obligations: rapport de synthèse. RTDcom, v. 51, n. 1, p. 126, janv./mars. 1998.
} 
Cláudia Lima MARQUeS, ainda, aponta a existência de mais um tipo, intrínseca do consumidor: a informacional ${ }^{79}$. Muitos autores entendem que tal vulnerabilidade já estaria englobada no conceito de vulnerabilidade técnica, uma vez que o déficit informacional não deixa de ser considerado falta de conhecimentos específicos sobre um produto ou serviço, conforme se verá a seguir. A autora, porém, entende que a vulnerabilidade informativa representa hoje o maior fator de desequilíbrio nas relações de consumo, daí porque merece ser destacada das demais, sendo essencial à dignidade do consumidor, principalmente enquanto pessoa física ${ }^{80}$.

A vulnerabilidade técnica resta caracterizada sempre que uma das partes não possui conhecimentos específicos sobre o objeto do contrato, podendo ser facilmente enganada quanto às características do bem ou serviço ou sua utilidade. Essa vulnerabilidade é presumida para o não-profissional, mas, excepcionalmente, mediante prova in concreto, poderá também ser caracterizada na relação entre dois profissionais, beneficiando um deles com as normas protetivas do $\mathrm{CDC}^{81}$.

Já a vulnerabilidade científica ocorre quando uma das partes tem deficiência em conhecimentos jurídicos específicos, de contabilidade ou de economia. Assim como na vulnerabilidade técnica, a científica é presumida para as pessoas físicas e os não profissionais, mas, para os profissionais, há presunção de que eles, necessariamente, têm conhecimentos mínimos sobre economia, para que possam exercer a profissão, e têm plenas condições de consultar um advogado e/ou um contador sempre que assim for necessário $^{82}$.

Por fim, há a vulnerabilidade fática ou socioeconômica, em que o ponto de concentração é o outro parceiro contratual. Pode ser verificada sempre que um dos contratantes está em posição de monopólio, fático ou jurídico, apresenta grande poder econômico, ou oferece um produto ou serviço essencial para o outro contratante, e, por conta disso, acaba por impor a sua superioridade ao contratante vulnerável ${ }^{83}$.

Para parte da doutrina, o conceito de vulnerabilidade não deve ser confundido com o conceito de hipossuficiência. ANTONIO CARLOS MORATO entende que a vulnerabilidade é o gênero do qual a hipossuficiência é espécie. A hipossuficiência estaria relacionada à

\footnotetext{
${ }^{79}$ Cf. MARQUES, Cláudia Lima. Campo de aplicação do CDC, cit., p. 71.

${ }^{80} \mathrm{Cf}$. Id. Ibid., p. 75.

${ }^{81}$ Cf. Id. Ibid., p. 71-72.

${ }^{82}$ Cf. Id. Ibid., p. 72.

${ }^{83}$ Cf. Id. Ibid., p. 73.
} 
capacidade econômica da pessoa, física ou jurídica ${ }^{84}$, daí porque o porte econômico de uma empresa, por exemplo, nem sempre seria um fator relevante para sua caracterização ou não como consumidora, uma vez que é a vulnerabilidade - em qualquer uma de suas modalidades - o principal elemento para a caracterização do consumidor ${ }^{85}$. TARTUCE, por outro lado, entende que o conceito de hipossuficiência consumerista é mais amplo, não se resumindo ao sentido literal de "pobre" ou "sem recursos". Tal conceito também abrangeria, por exemplo, a deficiência técnica. Tanto um quanto outro, porém, chegam à mesma conclusão, isto é, embora todo consumidor seja vulnerável, somente alguns são hipossuficientes ${ }^{86}$. Vale lembrar, finalmente, que o STJ ensina que a hipossuficiência é a noção processual da vulnerabilidade fática, levando, por exemplo, a considerar abusivas algumas cláusulas de eleição de foro ${ }^{87}$.

No julgamento da ação direta de inconstitucionalidade $n^{\circ} 2591$, o Sr. Ministro Carlos Velloso, analisando a questão da vulnerabilidade do mutuário perante a instituição financeira, acertou ao dizer em seu voto que o verbo mais adequado para se aferir a vulnerabilidade do consumidor é o "estar", e não o "ser". De fato, o consumidor não necessariamente é vulnerável já no momento prévio da contratação. É preciso constatar essa situação antes, durante e após a contratação. Pode ser, por exemplo, que um empresário (cliente cativo) venha a se tornar vulnerável face a seu parceiro contratual, em razão da imposição de cláusulas abusivas no curso de um contrato de longa duração.

\subsection{Consumidor por equiparação}

O CDC apresenta três conceitos básicos de consumidor equiparado, a saber: (i) o conceito estabelecido no parágrafo único do art. $2^{\text {o; }}$; (ii) aquele previsto no art. 17 ; e, finalmente (iii) o conceito do art. 29.

\footnotetext{
${ }^{84} \mathrm{~A}$ caracterização da hipossuficiência da pessoa jurídica, contudo, é mais restrita e excepcional que a da pessoa física.

${ }^{85}$ ANTONIO CARLOS MORATO esclarece que a hipossuficiência passa a ser o principal critério em apenas alguns dispositivos do CDC, em especial o que estabelece a inversão do ônus da prova - embora às pessoas jurídicas ainda fosse possível solicitar a referida inversão com base na verossimilhança da alegação (Cf. MORATO, Antonio Carlos. op. cit., p. 115-143).

${ }^{86}$ Cf. MORATO, Antonio Carlos. op. cit., p. 38; e TARTUCE, Flavio. Função social dos contratos: do Código de Defesa do Consumidor ao Código Civil de 2002, cit., p. 110.

${ }^{87}$ Vide Resp 200.390-SP, 5 Turma, Min. Rel. Edson Vidigal, j. 24/10/2000.
} 
$\mathrm{O}$ art. $2^{\circ}$, parágrafo único, do CDC prescreve que "equipara-se a consumidor, a coletividade de pessoas, ainda que indetermináveis, que haja intervindo nas relações de consumo". Tal norma tem caráter geral, de interpretação, sendo aplicável a todos os capítulos e seções do CDC; tem por objetivo estender as normas protetivas do CDC não apenas ao consumidor stricto sensu, destinatário final do bem, mas também à coletividade de pessoas prejudicadas que tenham, de alguma forma, participado da relação de consumo.

O conceito jurídico de consumidor do CDC, portanto, mesmo para aqueles que defendem a Teoria Finalista, é mais abrangente do que o conceito econômico antes abordado, pois não protege apenas quem praticou o ato de consumo, mas todos aqueles que tenham intervindo na relação de consumo ${ }^{88}$.

$\mathrm{O}$ art. 17, por sua vez, determina que "para efeitos desta Seção [que trata da responsabilidade pelo fato do produto ou serviço], equiparam-se aos consumidores todas as vítimas do evento". Em tal hipótese, considera-se presumida a vulnerabilidade daquele que adquire um produto ou serviço defeituoso, desnecessária a comprovação de quaisquer requisitos para a aplicação das normas do CDC. Bastará, para tal fim, que o sujeito tenha sido vítima de um defeito, nos termos da Seção II do Capítulo IV do CDC.

$\mathrm{O}$ art. 17 e o parágrafo único do art. $2^{\circ}$ se complementam (os conceitos estão relacionados, mas o art. 17 é mais específico, pois se aplica somente aos casos de responsabilidade pelo fato do produto ou serviço), e atribuem proteção ao terceiro (bystander) que, embora não tenha efetivamente adquirido o bem (retirado do mercado), acabe também se prejudicando por um defeito do produto ou serviço. Um bom exemplo é o caso de uma filha que adoece por fato do produto adquirido pelo pai ${ }^{89}$.

Interessa para o presente estudo, particularmente, a disposição do art. 29 desse código, a qual estabelece que, para os fins dos capítulos referentes às práticas comerciais e à proteção contratual, "equiparam-se aos consumidores todas as pessoas determináveis ou não, expostas às práticas nele previstas”.

Algumas pessoas entendem que se equiparam a consumidores todas as pessoas expostas às práticas comerciais abusivas ou contrárias às políticas de consumo delineadas no aludido código. Outras, porém, acreditam que se equiparam aos consumidores apenas aquelas pessoas expostas às práticas comerciais abusivas previstas no Capítulo V do CDC.

\footnotetext{
${ }^{88}$ Cf. DE LUCCA, Newton. op. cit., p. 124.

${ }^{89}$ Cf. MARQUES, Cláudia Lima. Campo de aplicação do CDC, cit., p. 77.
} 
Independentemente de qual seja a interpretação, contudo, fato é que muitos empresários estão sujeitos às práticas comerciais abusivas previstas no $\mathrm{CDC}$ como um todo ou no próprio Capítulo V desse diploma legal.

Controverte-se a doutrina, no entanto, acerca do alcance de tal equiparação. Assim como para a definição do consumidor stricto sensu é possível notar a presença de autores maximalistas e de autores finalistas, também na hora da definição do consumidor equiparado essas mesmas correntes fazem valer seus conceitos mais ou menos abrangentes.

Os autores maximalistas conferem maior extensão ao conceito do art. 29, afirmando que sua aplicação independe de quaisquer considerações subjetivas a respeito da pessoa a ser equiparada, bastando o fato objetivo da exposição a práticas abusivas. Assim entende, por exemplo, ALINE ARQUETTE NovAIS, para quem qualquer pessoa exposta ao abuso de uma prática comercial estabelecida no $\mathrm{CDC}$, tais como oferta, publicidade, práticas abusivas, cobrança de dívidas e bancos de dados e cadastros de consumidores, bem como qualquer pessoa sujeita a um contrato que contemple cláusulas abusivas é considerada consumidor e, portanto, está apta a agir como tal, fazendo uso das normas desse código para defender seus direitos ${ }^{90}$.

Em casos de contrato de adesão, os defensores desta corrente propugnam a idéia de que o simples fato da contratação se efetivar por essa forma massificada já seria suficiente para a aplicação das normas do CDC, eis que se presumiria, nesses casos, a vulnerabilidade do aderente.

A mesma autora enfatiza esse entendimento ao afirmar que o Capítulo VI do CDC, ao qual se refere o citado art. 29, trata da proteção contratual, arrolando exemplificativamente as cláusulas abusivas e disciplinando os contratos de adesão. Entende a autora que, quanto aos contratos de adesão, deve-se ter em vista que o aderente sempre é consumidor, por equiparação legal, independentemente de ser destinatário final de um produto ou serviço, o que nem sequer é cogitado. Para ela, essa é a única e possível interpretação do art. 29 do código em questão, se se quiser atender aos princípios basilares que norteiam toda a disciplina consubstanciada na Lei 8.078/90, isto é, o princípio da boafé objetiva e o princípio da tutela do contratante hipossuficiente ${ }^{91}$.

\footnotetext{
${ }^{90} \mathrm{Cf}$. NOVAIS, Alinne Arquette Leite. A teoria contratual e o Código de Defesa do Consumidor. São Paulo: Ed. Revista dos Tribunais, 2001. p. 142.

${ }^{91}$ Cf. Id. Ibid., p. 164.
} 
Para outra parte da doutrina, entretanto, a interpretação do referido art. 29 não pode ter alcance tão extenso. Aqui, parte-se da premissa de que a finalidade do CDC é, precipuamente, tutelar de forma especial um grupo de pessoas também especial, vulnerável. Isso, como forma de se prestigiar o princípio da igualdade, albergado pelo art. $5^{\circ}$ da Constituição Federal e, de resto, ínsito à própria noção de democracia.

Na medida em que o CDC presumiria a vulnerabilidade apenas e tão-somente para o consumidor stricto sensu previsto no caput do art. $2^{\circ}$, beneficiar com suas normas especiais agentes econômicos em relação aos quais não se pode presumir essa fragilidade representaria, antes que uma homenagem, uma intolerável afronta ao princípio da igualdade. Assim, para tais autores, a equiparação de que trata o mencionado art. 29 não prescinde, em absoluto, da prova da vulnerabilidade a justificar a tutela especial.

Expoente desse pensamento é ClÁUdiA LIMA MARQues, para quem, no caso de extensão do campo de aplicação do CDC face ao art. 29, a vulnerabilidade continua sendo elemento essencial, tendo sido superado apenas o critério da destinação final. Obtempera a autora que, mesmo não sendo destinatário final (fático ou econômico) do produto ou serviço, o agente econômico ou profissional liberal pode vir a ser beneficiado pelas normas tutelares do referido código enquanto consumidor-equiparado. A interpretação finalista que a autora defende tem sua base na vulnerabilidade (presumida ou comprovada) do sujeito de direitos tutelado pela lei, e restringe conscientemente a figura do consumidor stricto sensu àquele que adquire (utiliza) um produto para uso próprio e de sua família, permitindo a equiparação dos arts. 17 e 29 do CDC somente com base em prova de tal equiparação ${ }^{92}$.

Esse também foi o entendimento consolidado no IV Congresso Brasileiro de Direito do Consumidor, realizado em Gramado, no estado do Rio Grande do Sul, no Painel sobre Serviços Bancários e Financeiros, onde foi aprovada, por maioria, a seguinte conclusão: "As regras dos Capítulos V (Das Práticas Comerciais) e VI (Da Proteção Contratual), do Título I, do Código de Defesa do Consumidor, por força do disposto no art. 29, aplicam-se, sem restrição, às relações jurídicas profissionais (pessoas físicas ou jurídicas), sempre que, em concreto, evidenciada a situação de desequilíbrio entre os figurantes (vulnerabilidade em concreto)" ${ }^{93}$.

\footnotetext{
${ }^{92}$ Cf. MARQUES, Cláudia Lima. Contratos no Código de Defesa do Consumidor. São Paulo: Ed. Revista dos Tribunais, 2002. p. 291 e 313.

${ }^{93}$ Revista de Direito do Consumidor, São Paulo, n. 26, p. 243-244.
} 
Tal pensamento é fruto da evolução da Teoria Finalista, como visto anteriormente, e tem por objetivo acomodar os diversos sujeitos vulneráveis presentes no mercado, sem, contudo, banalizar a aplicação das normas do CDC. Será, portanto, o posicionamento a balizar o presente estudo. Afinal, como aponta CLÁUdIA LIMA MARQUES:

“(...) Sempre há o perigo de considerarmos a todos e em todas as situações como consumidores (dois iguais civis, dois iguais comerciantes entre eles), como queria a teoria maximalista. De outro lado, há perigo também quando menosprezamos as equiparações legais que o CDC expressamente impôs e deixamos sujeitos de direitos em situações análogas de vulnerabilidade, sem a proteção especial. Daí a importância do finalismo aprofundado (...)" ${ }^{\prime 94}$.

O art. 29 é, atualmente, a norma extensiva do campo de aplicação do CDC mais importante, e não tem por objetivo simplesmente apresentar uma definição adicional de consumidor. Mais do que isso, imprime uma política legislativa, deixando nas mãos do aplicador da lei a tarefa de harmonizar os interesses presentes no mercado, reprimir os abusos de poder econômico e proteger os interesses econômicos dos consumidores finais. Trata-se de um podereso instrumento nas mãos daquelas pessoas, inclusive agentes econômicos, expostas às práticas abusivas ${ }^{95}$.

Afinal, o consumidor nem sempre é a parte fraca da relação, daí a importância de se ter um conceito de consumidor que leve em conta a situação real da pessoa, seja física ou jurídica. Atribuir as normas protetivas do CDC somente ao destinatário final do produto ou serviço poderia desvirtuar toda a lógica do sistema, especialmente nas situações em que o consumidor é quem está em posição de superioridade.

\subsection{CDC e o Novo Código Civil}

\subsubsection{Teoria dos Sistemas}

"Sistema", em sentido técnico, significa um conjunto de elementos organizados para certa finalidade. Em sua origem grega, "sis" significava "junção/reunião" e "thêma" significava "proposição/assunto". O sistema, portanto, é uma forma, um

\footnotetext{
${ }^{94}$ MARQUES, Cláudia Lima. Campo de aplicação do CDC, cit., p. 77.

${ }^{95}$ Cf. Id. Ibid., p. $78-79$.
} 
método de unificar e organizar um assunto. Há, em tal definição, a idéia de ordem e unidade.

Ao contrário de alguns termos semelhantes, tal como "conjunto", "estrutura" ou mesmo "teoria”, que também passam a idéia de organização, mas no sentido estático do termo, a palavra "sistema" traz uma idéia de dinâmica, ou seja, de um conjunto organizado, mas que está em formação e transformação, e no qual existe uma constante relação entre os elementos que o formam.

A noção de "sistema" surgiu na Era Moderna, a partir de 1600, em razão da necessidade de se estabelecer métodos técnico-formais e racionais de organização, como forma de superar o caos instalado na época medieval. Historicamente, os gregos empregaram a palavra "sistema" na filosofia, a qual unia três "sistemas" diversos, porém articulados entre si, a saber: a lógica, a física e a ética, existindo uma sinergia entre eles.

O termo foi esquecido até o surgimento do movimento Iluminista que, nos séculos XVII e XVIII, revigorou a idéia de "sistema". Tal termo, notadamente a partir do início do século XIX, passou a ser utilizado inclusive no campo do direito ${ }^{96}$. O maior desenvolvimento do conceito de "sistema" no campo do direito, todavia, é devido aos alemães, especialmente a CANARIS e TEUBNER ${ }^{97}$, mas, inicialmente, o conceito foi utilizado para passar uma idéia de que o "sistema jurídico" seria totalitário, ou seja, um todo acabado, de forma que nada que estivesse "fora" dele poderia ser considerado direito.

A atual teoria da sistêmica é contrária à idéia de ciências estanques, que não se relacionam, não se interpenetram. O sistema deve ser entendido como um modelo funcional que pode servir para diversas formas de conhecimento. Trata-se de um

\footnotetext{
${ }^{96}$ LUHMANN mostra a passagem do sistema jurídico como sistema de conceito a um sistema de ação. Aponta o jurista que, inicialmente, o termo "sistema" era visto como um método de ordenação e classificação dos ramos do conhecimento. Era utilizado, por exemplo, para se estruturar um livro como forma expositiva. Tal conceito de sistema, contudo, mostrou-se insuficiente para a matéria jurídica. A partir do início do século XIX, com a evolução de outras disciplinas, sobretudo no campo da biologia, foi constatado que a análise funcional do objeto acabava privando a classificação sistemática do seu caráter facultativo e hipotético. Isso forçou a ciência a afastar a noção de sistema que até então prevalecia e a fundar sua própria sistemática, movida e mutável a partir de seu objeto. Foi a partir das idéias de JHERING que esse mesmo movimento começou a se manifestar no campo da ciência jurídica (Cf. LUHMANN, Niklas. Sistema giuridico $e$ dogmatica giuridica. Traduzione e introduzione di Alberto Febbraio. Bologna: Il Mulino, 1978. p. 36-38).

${ }^{97}$ Cf. KUHN, Adriana Menezes de Simão. O tempo e a catividade nos contratos: elementos para uma abordagem sistêmica da teoria dos contratos. In: MARQUES, Claudia Lima (Coord). A nova crise do contrato: estudos sobre a nova teoria contratual. São Paulo: Ed. Revista dos Tribunais, 2007. p. 458.
} 
conceito metodológico, ou seja, estudam-se métodos para a aplicação de determinado assunto/objeto à realidade, conferindo-lhe uma utilidade prática.

Embora, em tal concepção, a palavra "sistema" traga uma noção dinâmica e de inclusão, ela também deixa transparecer o que lhe é interno e externo, isto é, o que pertence e o que não pertence a um determinado sistema.

O sistema jurídico propriamente dito comporta, igualmente, essa definição "geral", ou seja, de um conjunto organizado, composto por diversos elementos (heterogêneos) que se inter-relacionam (dinâmico), por meio de relações variadas. Por isso, pode-se dizer que o direito é um sistema complexo.

O sistema jurídico, porém, tem uma peculiaridade, pois sua noção traz intrínseca a definição de dois tipos de sistema: o intrínseco, relativo ao seu funcionamento, e o extrínseco, relativo ao seu método de exposição.

O sistema jurídico intrínseco é composto por diversos diplomas normativos, que interagem entre si e integram o direito (Constituição, leis, decretos, portarias etc.), dando margem a discussões quanto à hierarquia das normas. Já o sistema jurídico extrínseco procura explicar o sentido e dar o alcance de tais normas, interpretando-as. Consiste no método de ensinar o direito ("methodus disponendi"). A divisão em Direito Público e Privado, as subdivisões do direito civil, em parte geral, direito das obrigações, contratos, direito de família e sucessões, por exemplo, são obra do sistema extrínseco.

A atuação do sistema jurídico extrínseco se dá pelas instituições, como os Tribunais e as Assembléias Legislativas, pelos operadores do direito, como os juízes, promotores e advogados, os quais formam, por sua vez, a jurisprudência, e também pelos doutrinadores.

O sistema jurídico, portanto, não é formado apenas por normas. Pelo contrário, há uma retro-alimentação do sistema jurídico (feed-back) pelos seus diversos elementos. Em outras palavras, as normas atuam sobre os outros elementos do sistema, e esses, a partir da aplicação das próprias normas, atuam sobre elas e sobre cada um desses elementos. O juiz, por exemplo, aplica o que aprendeu por meio da doutrina (doutrina influenciando a jurisprudência) e alimenta-a, por sua vez, com as decisões proferidas (jurisprudência influenciando a doutrina). Por força de uma interpretação dada pela jurisprudência e pela doutrina, por seu turno, a Assembléia Legislativa pode promulgar ou modificar uma lei, de 
forma a chancelar aquela interpretação (jurisprudência e doutrina influenciando as normas).

Ordenamento jurídico e sistema, portanto, não são termos sinônimos. Ordenamento jurídico significa o conjunto de normas reguladoras da vida jurídica, num campo territorial específico ${ }^{98}$. Sistema, por seu turno, exprime as ligações entre as diversas normas, conferindo uma idéia de inter-relação, unidade e dinamicidade. A partir da constatação de que o direito não se traduz apenas em um emaranhado de normas, tornou-se necessária a reformulação da tese puramente positivista do direito. Passou-se, por exemplo, a sistematizar os princípios, os quais passaram a ser considerados normas jurídicas, incluídas nas Constituições de diversos países, tal como ocorreu no Brasil, em 1988. Parte desse movimento teve origem a partir da Segunda Guerra Mundial, uma vez que o nazismo havia utilizado a idéia de sistema jurídico "fechado" para justificar as atrocidades cometidas durante o regime.

Finalmente, vale lembrar que o direito é um sistema de segunda ordem, o que significa dizer que tem um caráter instrumental, ou seja, está dentro de um sistema maior: o social. O direito não existe de forma isolada, mas em função do sistema social.

No passado, a civilização romana separou o sistema jurídico de outros sistemas, como a religião e a filosofia, conferindo-lhe identidade própria, em movimento contrário ao que outras civilizações, como a egípcia, a chinesa ou a hindu, vinham fazendo. Posteriormente, a civilização ocidental adotou o mesmo critério "separatista", apartando o sistema jurídico de outros sistemas, como o político e o econômico.

A origem desse movimento "separatista" está na teoria desenvolvida pelos chilenos Maturana e VARElla, no campo da biologia, para a definição de vida (teoria da autopoiese), segundo a qual a vida é uma auto-criação, ou seja, o organismo vital se mantém por si próprio em razão dos processos moleculares produzidos pela atividade celular e dos processos neuronais produzidos no sistema nervoso. A autopoiese, palavra grega que significa "criar-se a si mesmo" ("auto" traz a idéia de "para si próprio" e "poiese" de criação), foi transportada para o campo do direito para inserir o conceito de autonomia jurídica. $\mathrm{O}$ sistema jurídico seria autopoiético na medida em que ele próprio admite que o direito traga soluções de outras esferas para o caso concreto ${ }^{99}$. O próprio

\footnotetext{
${ }^{98}$ Trata-se do ordenamento jurídico positivo, na classificação de CARNELUTTI (Cf. CARNELUTTI, Francesco. Teoria generale del diritto. 3. ed. Roma: Soc. Ed. Del Foro Italiano, 1951. p. 71-72).

${ }^{99}$ Nesse sentido, vide: KUHN, Adriana Menezes de Simão. op. cit., p. 458-460.
} 
direito, por exemplo, autorizaria a importação de princípios éticos e morais para aplicação no caso concreto e, somente por meio desse exercício, que um princípio ético tornar-se-ia jurídico $^{100}$. Tal teoria merece críticas, pois leva à idéia do direito como um sistema fechado, separado do sistema social ${ }^{101}$.

$\mathrm{Na}$ realidade, a autonomia atribuída ao direito é meramente relativa (operacional), pois muito embora este possua regras próprias, foi criado e está organizado em função da sociedade, com um duplo objetivo: (i) prevenir os conflitos; e (ii) na impossibilidade de os prevenir, atuar como um meio para resolução de tais conflitos, restabelecendo a paz e a harmonia na sociedade.

Existe, portanto, uma autonomia entre o sistema social e o sistema jurídico, tendo cada um deles identidade própria. Porém, o sistema jurídico tem por função primordial captar as informações sociais e trabalhar com elas de tal modo a resolver os conflitos criados na sociedade, servindo como uma espécie de filtro.

A título ilustrativo, podemos lembrar que não é o direito que cria o contrato ou o negócio jurídico. A sociedade, a vida social, leva à criação dos contratos e dos negócios jurídicos, os quais, posteriormente, são agasalhados pelo sistema jurídico. Em outras palavras, a sociedade confere o poder negocial às partes para dizer que aquela conduta do contratante vincula (autonomia social) ${ }^{102}$. Da mesma forma, no momento da criação de suas leis e aplicação destas aos casos concretos, por meio da interpretação normativa, o sistema jurídico recebe também influência dos sistemas político e econômico, por exemplo.

\footnotetext{
${ }^{100}$ TEUBNER, por exemplo, considera o direito um sistema autopoiético de segunda ordem, uma vez que ele estabelece um fechamento operacional independente em relação à sociedade, que é um sistema autopoiético de primeira ordem. Esse fechamento operacional se instaura pela produção auto-referencial dos componentes sistêmicos e pela junção destes em um hiperciclo. O jurista aponta, contudo, que os próprios biólogos criadores do conceito da autopoiese criticam a extensão desse conceito ao sistema jurídico, uma vez que um fenômeno social como o direito é inapto à elaboração de uma autopoiese independente. Para esses autores, a real autopoiese seria restrita à vida orgânica. (Cf. TEUBNER, Gunther. Le droit, um système autopoïétique. Traduzido do alemão por Gaby Maier e Nathalie Boucquey. Paris: Presses Universitaires de France, 1993. p. 43-45).

${ }^{101}$ Celso CAMPILONGO, ao defender a tese de LuHMANN de que o sistema jurídico seria um sistema fechado esclarece que o fechamento operacional é tão importante uma vez que ele é o responsável pela unidade do sistema. Para LuHMANN, os problemas de abertura e fechamento do sistema não podem ser respondidos a partir do esquema "input/output". Tal discussão perde sentido nesse contexto, na medida em que fechamento operacional não é sinônimo de irrelevância do ambiente ou de isolamento causal. Assim, o fechamento operacional de um sistema seria condição para sua própria abertura (Cf. CAMPILONGO, Celso Fernandes. Política, sistema jurídico e decisão judicial. São Paulo: Max Limonad, 2002. p. 65-71). Em relação às noções de "input" e "output" do sistema, vide: LUHMANN, Niklas. op. cit., p. 59-71.

${ }^{102}$ Sobre o surgimento dos institutos jurídicos e sua relação com a idéia de sistema, vide: IRTI, Natalino. L'Età della decodificazione. 4. ed. Milano: Giuffrè, 1999. p. 152-153.
} 
É inegável que as recentes transformações pelas quais vem passando o direito civil são fruto das influências recebidas de outros ramos, primordialmente o social ${ }^{103}$. A edição do Código Civil de 2002, com a inclusão dos princípios sociais em seu texto, demonstra apenas parte dessa transformação.

O sistema jurídico, portanto, no desempenho de sua função, recebe os influxos da sociedade, não havendo autonomia absoluta, como quer a autopoiese ${ }^{104} . \mathrm{E}$, em tal exercício, além de indicar qual a regra que deve ser aplicada a um determinado conflito (por meio de normas de direito material), também estabelece o procedimento a ser seguido para a resolução do conflito (mediante normas de direito processual). Estas últimas normas, por sua vez, também têm tradicionalmente o caráter instrumental, na medida em que não servem pura e simplesmente para regular procedimentos de ordem formal, mas, fundamentalmente, para ajudar a resolver os conflitos sociais. Nota-se, por conseguinte, que não seria possível atingir a dupla função exercida pelo direito por meio de um apelo puro e simples a outros sistemas (político, econômico ou moral, por exemplo), desconsiderando-se os normas por ele estabelecidas. Para que seja possível estabelecer a paz social, devem ser sempre respeitadas as formas do direito, em especial, as relacionadas ao plano da validade.

\subsubsection{CDC como um microssistema}

Tomando-se o direito como um sistema, nota-se ainda subdivisões dentro dele, como o direito civil, o direito penal, o direito comercial (ou empresarial, como se diz hodiernamente) etc., os quais, por seu turno, apresentam ainda outras subdivisões, como é o caso da Lei das Sociedades Anônimas, da Lei Antitruste, da Lei dos Direitos Autorais, do

\footnotetext{
${ }^{103}$ Como aponta TERESA NEGREIROS, “(...) o Direito não está recluso em si mesmo, (...) por isso, tanto quanto outros ramos, o direito civil responde às demandas sociais, e estas, uma vez alteradas, resultam em correspondentes alterações nos institutos jurídicos" (NEGREIROS, Teresa. op. cit., p. 6).

${ }^{104}$ Vale apontar, contudo, que TEUBNER defende que a autopoiese do sistema jurídico não exclui as interações entre direito e sociedade. Pelo contrário, as interações seriam possíveis, só que os elementos de influência deveriam ser reformulados e seriam distinguidos por um caráter externo e periférico, ao contrário dos elementos internos do próprio sistema jurídico. (Cf. TEUBNER, Gunther. op. cit., p. 45). Nesse mesmo sentido, Celso CAMPILONGO esclarece que "descrever um sistema como operativamente fechado não significa dizer que, na totalidade de suas condições empíricas, esse sistema não mantenha contatos com o ambiente. (...) A questão é saber que tipo de operação interna capacita um sistema a formar uma rede que auto-reproduz seus elementos, que se coliga a informações autogeradas pelo sistema e que é capaz de distinguir suas necessidades internas daquilo que vê como problemas do ambiente" (CAMPILONGO, Celso Fernandes. op. cit., p. 67).
} 
direito do consumidor, entre outros. São os chamados microssistemas, que, apesar de estarem dentro do sistema jurídico, possuem uma lógica e princípios próprios, sendo, portanto, capazes de se auto-organizar ${ }^{105}$.

Os microssistemas permanecem ligados estruturalmente ao sistema, com ele relacionando-se e provocando influências recíprocas. Não há que se falar em pluralismo de ordenamentos jurídicos, uma vez que os microssistemas surgem com a função de regular as lacunas que os códigos, mais gerais e abrangentes, não conseguem regulamentar, ou até mesmo prover expectativas normativas (principal função do direito) ${ }^{106}$.

$\mathrm{O}$ aumento da complexidade da sociedade tornou necessária a edição de leis que tratassem de matérias específicas, as quais demandavam princípios e lógicas distintas daquelas dos códigos gerais. Um bom exemplo disso foi o que ocorreu com o direito comercial, cujo código, publicado em 1850, atendia às necessidades da época. Com o passar dos anos, porém, o surgimento de novos institutos e o aperfeiçoamente daqueles já existentes passaram a exigir a criação de leis especiais, capazes de resolver essas novas questões e garantir as expectativas normativas de forma adequada ${ }^{107}$.

Assim, muito embora a lei especial possa apenas complementar um código ou uma lei geral, ela pode também constituir o direito geral de um instituto específico ou de uma matéria inteira. É nesse ponto que se passa a falar em microssistemas - e não subsistemas, uma vez que não há relação de subordinação entre o microssistema e o sistema geral $^{108}$.

Não foi diferente com o direito do consumidor. Historicamente, a defesa do consumidor sempre se deu no âmbito do direito econômico, mas a necessidade de proteção da parte vulnerável ou hipossuficiente, de um lado, e de regulação do mercado, de outro, especialmente dos contratos de adesão, que eram carentes de regulação por parte do Estado, fez surgir um anseio pela edição de um código específico para tal fim, capaz de estabelecer um equilíbrio de forças entre as partes contratantes e, com isso, incentivar o consumo $^{109}$.

Embora já existissem normas esparsas com o intuito de conferir proteção ao consumidor, a microcodificação do direito do consumidor, baseada no consumerismo

\footnotetext{
${ }^{105}$ Cf. STAGNI, Alexandre; NOGUEIRA, André Coutinho; CABELEIRA, Caio; OUCHANA, Elber Christian; GOMES, Guilherme Amado. op. cit., p. 228.

${ }^{106}$ Cf. Id. Ibid., p. 228.

${ }^{107} \mathrm{Cf}$. Id., loc. cit.

${ }^{108}$ Cf. IRTI, Natalino. op. cit., p. 38-39 e 70-71.

${ }^{109}$ Cf. STAGNI, Alexandre; NOGUEIRA, André Coutinho; CABELEIRA, Caio; OUCHANA, Elber Christian; GOMES, Guilherme Amado. op. cit., p. 228 e 232.
} 
norte-americano, teve origem somente após a promulgação da Constituição de 1988, que listou, dentre os direitos fundamentais, a defesa do consumidor (art. $5^{\circ}$, XXXII), além de ordenar expressamente a elaboração de uma microdificação no art. 48 do Ato das Diposições Constitucionais Transitórias - ADCT.

Como bem definido por CláUdia LiMA MARQUES:

\begin{abstract}
“'código' significa um conjunto sistemático e logicamente ordenado de normas jurídicas, guiadas por uma idéia básica; no caso do CDC (Lei $n^{o}$. 8.078/90), esta idéia é a proteção (ou tutela) de um grupo específico de individuos, uma coletividade de pessoas, de agentes econômicos, os consumidores" ${ }^{\prime 10}$.
\end{abstract}

O CDC é um conjunto de normas sistematicamente organizado, que abrange regras de Direito Privado, regras administrativas, penais, processuais e sobre direito intertemporal, sob o manto de princípios e valores comuns, de origem constitucional, todas elas tendo em vista uma finalidade comum, que é a proteção do consumidor. O CDC, assim, é uma micro codificação de normas especiais, já que tem por objetivo privilegiar um grupo de sujeitos $^{111}$.

A idéia de microssistema pode ser também exsurgida da preocupação do próprio legislador em facilitar a interpretação das normas do código que criou. Nessa linha de raciocínio, o legislador indicou em seu texto os objetivos perseguidos pela lei (art. $4^{\circ}$ do CDC), dividiu o código em parte geral e parte especial, além de dividi-lo em títulos, capítulos e seções.

A parte geral do CDC, formada pelos três pimeiros capítulos (arts. $1^{\circ}$ ao $7^{\circ}$ ), estabelece as definições, conceitos, princípios, objetivos, direitos e normas que deverão ser levados em consideração na aplicação de qualquer outra norma do CDC, seja de natureza civil, administrativa, penal ou processual. Além disso, o Capítulo I traz a hierarquia das normas do $\mathrm{CDC}$, pois, embora este não tenha sido aprovado na forma de código ou de lei complementar (é formalmente uma lei ordinária) ${ }^{112}$, materialmente é uma lei com

\footnotetext{
${ }^{110}$ MARQUES, Cláudia Lima. A Lei 8.078/90 e os direitos básicos do consumidor. In: BENJAMIN, Antônio Herman V.; MARQUES, Cláudia Lima; BESSA, Leonardo Roscoe. Manual de direito do consumidor. São Paulo: Ed. Revista dos Tribunais, 2008. p. 44.

${ }^{111} \mathrm{Cf}$. Id., loc. cit.

${ }^{112}$ Vale notar, como aponta NATALINO IRTI vinte após após a edição de sua famosa obra L'Età della decodificazione, que a descodificação é um instrumento de política legislativa. Embora as leis especiais consigam exprimir mais facilmente os impulsos de novidade dos partidos e grupos políticos, num momento de crise, em que a sociedade demande continuidade e estabilidade, os códigos acabam demonstrando um plus de valor histórico que as leis especiais não têm, na medida em que se mostram muitas vezes pobres e efêmeras (Cf. IRTI, Natalino. op. cit., p. 9-10).
} 
verdadeira função social (é lei de ordem pública econômica e de interesse social, com origem claramente constitucional). Por serem normas de ordem pública - ou seja, são normas de Direito Privado, com forte interesse público, pois trazem os valores básicos e fundamentais de nossa ordem jurídica - são indisponíveis e inafastáveis contratualmente ${ }^{113}$.

Segundo F. B. SILVA, o CDC é um microssistema normativo eficiente em razão dos princípios em que se funda, que se irradiam diretamente da Constituição Federal. Tais princípios propiciam ao consumidor um tratamento diferenciado em uma economia de mercado, em função das relações jurídicas que envolvem os atores desse tipo de relação ${ }^{114}$. A grande quantidade de instrumentos e maneiras criados para garantir maior eqüidade nas relações de consumo também é um dos motivos aptos a tornar esse diploma tão eficiente. Como exemplo, podemos citar a inversão do ônus da prova, a possibilidade de desconsideração da personalidade jurídica, a aplicação da onerosidade excessiva, a disciplina das cláusulas abusivas, entre muitos outros.

Muito embora o CDC também siga em parte o modelo tradicional dos contratos, fundado nos princípios do pacta sunt servanda e da autonomia da vontade, preocupa-se muito mais em buscar o equilíbrio entre partes econômica, fática ou tecnicamente desiguais. Para tanto, passa a intervir em certos pontos das relações jurídicas estabelecidas, a fim de que não sejam criadas injustiças, preservando, assim, sua função social. A disciplina estabelecida pelo CDC nos traz a idéia de que, não obstante contratar continue sendo um ato de autonomia privada, é um ato sujeito a diversas disposições legais que impõem uma atuação racional, visto o contrato como pertencente a um sistema, e não como algo exclusivamente particular.

A compreensão das duas funções do CDC - proteção da parte vulnerável e regulação do mercado - torna possível entender a formação dos princípios e da lógica desse microssistema que é o direito do consumidor. De todo modo, assim como todos os outros microssistemas, o direito do consumidor, que traz em seu próprio corpo os elementos necessários para a interpretação de suas normas, está apto a sofrer influências e a influenciar diversos outros sistemas ${ }^{115}$.

\footnotetext{
${ }^{113}$ Cf. MARQUES, Cláudia Lima. A Lei 8.078/90 e os direitos básicos do consumidor, cit., p. 49-50 e 53.

${ }^{114}$ Cf. SILVA, Fernando Borges da. O Código de Defesa do Consumidor: um microssistema normativo eficiente? Disponível em: <http://jus2.uol.com.br/doutrina/texto.asp?id=7564>. Acesso em: 13 ago. 2008.

${ }^{115}$ Cf. A STAGNI, Alexandre; NOGUEIRA, André Coutinho; CABELEIRA, Caio; OUCHANA, Elber Christian; GOMES, Guilherme Amado. op. cit., p. 232.
} 


\subsubsection{Diálogo das fontes entre CDC e Código Civil}

Durante muito tempo acreditou-se que duas leis não poderiam tratar de uma mesma matéria sem que fosse instaurado um conflito de normas. Os critérios já conhecidos de solução de conflito de leis no tempo (anterioridade, especialidade e hierarquia) tinham por objetivo identificar a lei a ser aplicada, com a conseqüente revogação daquela não aplicada.

Atualmente, contudo, a doutrina está muito mais preocupada com a harmonia e coordenação entre as normas do ordenamento jurídico (concebido como sistema), do que com a exclusão de uma delas ${ }^{116}$. Tal mecanismo, como explica CLÁUdIA LIMA MARQUES, ficou conhecido pela expressão de ERIK JAYME "diálogo das fontes". "Diálogo", porque há a aplicação conjunta de duas ou mais normas ao mesmo tempo e ao mesmo caso, seja complementariamente, seja subsidiariamente, seja permitindo a opção voluntária das partes sobre a fonte prevalente ou mesmo permitindo uma opção por uma das leis em conflito abstrato, conforme se verá a seguir ${ }^{117}$.

O surgimento de "conflito" entre o Código Civil e o CDC, em tese, foi agravado após o advento do Código Civil em 2002, o qual unificou o direito comercial e o civil e passou a regular diversos contratos que também podem ser considerados de consumo. Um mesmo contrato, regulado em abstrato, pode ser civil, empresarial ou de consumo. A lei a ser aplicada, portanto, dependerá não somente do tipo de relação (seguro, serviço, compra e venda), mas também dos atores presentes. Se o contrato for entre iguais (entre dois consumidores, entre dois civis, entre dois empresários etc.), deverá ser regulado prioritariamente pelo Código Civil. Se o contrato for entre um consumidor e um fornecedor ou empresário, porém, será regulado pelo CDC e apenas subsidiariamente pelo Código Civil $^{118}$.

Em alguns casos, não obstante, a determinação de qual diploma deverá ser aplicado não é tão óbvia. Em tais situações, seguindo-se o sistema antigo, teríamos que analisar os critérios de conflito de leis no tempo. Nesse sentido, é possível afirmar que o CDC é lei anterior, especial e hierarquicamente constitucional, já que há mandamento expresso sobre

\footnotetext{
${ }^{116}$ Cf. MARQUES, Cláudia Lima. Diálogo entre o Código de Defesa do Consumidor e o novo Código Civil: do "diálogo das fontes" no combate às cláusulas abusivas. Revista de Direito do Consumidor, São Paulo, n. 45, p. 72, jan./mar. 2003.

${ }^{117}$ Cf. Id. Ibid., p. 74.

${ }^{118}$ Cf. Id. Ibid., p. 80-81.
} 
a sua criação no art. 48 do ADCT da Constituição Federal de 1988. Já o Código Civil de 2002 é lei posterior, geral e hierarquicamente inferior, embora traga algumas normas de ordem pública também, que devem ser aplicadas a todos os contratos, novos e antigos.

A revogação de um ou outro diploma, porém, não é o caminho mais coerente a ser seguido. Como visto, nos tempos atuais, presencia-se uma fase em que se deve buscar sempre a coordenação entre as diferentes fontes legislativas.

CláUdia Lima MARQues aponta a existência de três tipos de diálogo entre esses dois diplomas legais ${ }^{119}$, a saber: (i) diálogo sistemático de coerência; (ii) diálogo sistemático de complementariedade e subsidiariedade; e (iii) diálogo de coordenação e adaptação sistemática.

O primeiro deles ocorre quando, na aplicação simultânea de duas leis, uma delas serve como base conceitual para a outra. Tal se verifica especialmente nos casos em que uma das leis é geral e a outra especial, aplicável somente a um grupo da sociedade. A aplicação da lei especial prevalecerá no caso concreto, mas, para sua plena eficácia, deverá se valer de conceitos que estejam definidos na lei geral. O CDC, por exemplo, traz praticamente toda a disciplina a ser aplicada às relações de consumo, mas as definiçõoes de conceitos como prova, decadência e prescrição encontram-se no Código Civil.

O segundo tipo de diálogo pode ser verificado sempre que, na solução de antinomias reais ou aparentes ${ }^{120}$, uma lei puder ser aplicada de modo subsidiário ou complementar a um caso regulado por outra lei. Imagine-se, por exemplo, uma situação em que, embora se tratando de relação de consumo, as normas do Código Civil sejam mais benéficas ao consumidor do que as próprias normas do microssistema consumerista. Em tal hipótese, caberá ao legislador ou ao juiz, no caso concreto, determinar qual norma será aplicada e qual será utilizada somente de forma subsidiária ou complementar à outra ${ }^{121}$.

Por fim, o último caso de diálogo é encontrado sempre que se torna necessária a redefinição do campo de aplicação de uma lei. O próprio conceito de consumidor

\footnotetext{
${ }^{119}$ Cf. MARQUES, Cláudia Lima. Diálogo entre o Código de Defesa do Consumidor e o novo Código Civil: do "diálogo das fontes" no combate às cláusulas abusivas, cit., p. 76-82; e Id. Superação das antinomias pelo diálogo das fontes: o modelo brasileiro de coexistência entre o Código de Defesa do Consumidor e o Código Civil de 2002, cit., p. 57-61.

${ }^{120}$ Antinomia aparente é aquela que pode ser facilmente solucionada pela aplicação de um dos metacritérios de solução de conflito de leis (critérios cronológico, da especialidade e hierárquico). Já a antinomia real é aquela em que não há um metacritério capaz de solucionar o conflito de leis, ao menos de forma inicial (um exemplo é o conflito entre norma geral superior e norma especial inferior).

${ }^{121} \mathrm{O}$ próprio artigo $7^{\circ}$ do CDC autoriza o juiz, no caso concreto, a fazer uso do princípio do favor debilis, aplicando ao caso a norma mais benéfica ao consumidor, ainda que presente em diploma diverso do CDC.
} 
equiparado, presente no $\mathrm{CDC}$, está sujeito a um diálogo de influências recíprocas sistemáticas, já que pode sofrer influências finalísticas do Código Civil de 2002.

A possibilidade de aplicação conjunta e sistemática do CDC e do Código Civil em nosso ordenamento não é de espantar. Ambos os diplomas trazem intrínseca a mesma base principiológica $^{122}$. Aliás, o Código Civil de 2002 veio positivar, nas relações entre iguais, diversos princípios que antes só estavam previstos expressamente no $\mathrm{CDC}$, como é o caso da boa-fé objetiva, da função social dos contratos e da onerosidade excessiva, dentre outros $^{123}$.

A relação do CDC com o Código Civil, de cooperação e diálogo sem submissão, nas palavras de CláUdia LiMA MARQUES, é sui generis, diferindo da sistemática de diversos ordenamentos romano-germânicos ${ }^{124}$.

A França, por exemplo, organizou um Código de Consumo (Code de la Consommation), consolidando, em um só instrumento, todas as leis internas e diretivas especiais de defesa do consumidor ${ }^{125}$. Tal organização gira em torno do consumo e mercado de consumo, com todas as suas implicações, não tendo por base o consumidor (o critério não é subjetivo, como no direito brasileiro).

O modelo italiano, por sua vez, que também unificou o tratamento das obrigações civis e comerciais no Codice Civile, modificou pontualmente a parte especial de seu código para incluir a proteção do consumidor nas normas contratuais, num novo capítulo intitulado Dei contratti del consumatore. Tal alteração teve por objetivo atender a Diretiva 93/13/CEE, de 5 de abril de 1993.

Ao contrário do modelo brasileiro, a Itália optou por adotar um único código, dentro do qual se encontram algumas normas especiais para consumidores. Todavia, não é

\footnotetext{
${ }^{122} \mathrm{Ambos}$ os diplomas legais possuem a mesma terminologia e a mesma visão renovada da teoria contratual, permitindo a intervenção do Estado no conteúdo dos contratos, a visão da totalidade da obrigação, os deveres de boa-fé e a função social do contrato. É por esse motivo que não haverá entre eles antinomias de princípios, mas somente de normas ou antinomias aparentes (Cf. COSTA, Maria Aracy Menezes da. Os novos poderes/direitos oriundos do contrato no Código Civil de 2002 e no Código de Defesa do Consumidor: vontade das partes. In: MARQUES, Cláudia Lima (Coord). A nova crise do contrato: estudos sobre a nova teoria contratual. São Paulo: Ed. Revista dos Tribunais, 2007. p. 236 e 245).

${ }^{123} \mathrm{O}$ Enunciado 167 do Conselho da Justiça Federal esclarece que, com o advento de Código Civil de 2002, houve forte aproximação principiológica entre esse código e o CDC, eis que ambos são incorporadores de uma nova teoria geral dos contratos, baseada em dois princípios, a saber: a função social e a boa-fé objetiva.

${ }^{124}$ Cf. MARQUES, Cláudia Lima. A Lei 8.078/90 e os direitos básicos do consumidor, cit., p. 52; e Id. Superação das antinomias pelo diálogo das fontes: o modelo brasileiro de coexistência entre o Código de Defesa do Consumidor e o Código Civil de 2002, cit., p. 34 et seq.

${ }^{125} \mathrm{Cf}$. Id. Superação das antinomias pelo diálogo das fontes: o modelo brasileiro de coexistência entre o Código de Defesa do Consumidor e o Código Civil de 2002, cit., p. 42.
} 
possível afirmar que há uma codificação das normas consumeristas no sistema italiano, uma vez que, muito embora boa parte delas encontre-se no Codice Civile, há diversas outras esparsas no ordenamento, que também regulam de forma especial essa mesma categoria de sujeitos do mercado ${ }^{126}$.

Finalmente, a Alemanha adotou um modelo diferente e sistematizador, reintroduzindo todas as normas especiais, e até mesmo cláusulas gerais especiais, de defesa do consumidor em seu famoso BGB. O HGB (Código Comercial alemão), por outro lado, restou intacto. As relações de consumo, portanto, integram, hoje, o direito civil geral na Alemanha $^{127}$.

O modelo brasileiro traz dois códigos separados e autônomos (semelhante ao modelo francês), estabelece normas e cláusulas gerais especiais e mais fortes para a proteção do consumidor, sujeito presumidamente vulnerável (semelhante ao modelo alemão), e unifica as obrigações civis e empresariais, definindo o que entende por empresário (semelhante ao modelo italiano). Por outro lado, instituiu maior hierarquia à lei especial mais antiga - o CDC - ao invés do Código Civil (diferente do modelo italiano), e não incorporou a figura do consumidor no Código Civil (diferente do modelo alemão), tampouco a dos contratos de consumo (diferente do modelo italiano). Finalmente, por imposição constitucional, o microsistema consumerista tem por objetivo primordial a defesa do consumidor, e não do mercado (diferente do modelo francês) ${ }^{128}$.

\footnotetext{
${ }^{126}$ Cf. MARQUES, Cláudia Lima. Superação das antinomias pelo diálogo das fontes: o modelo brasileiro de coexistência entre o Código de Defesa do Consumidor e o Código Civil de 2002, cit., p. 42-43.

${ }^{127}$ Cf. Id. Ibid., p. 45-47.

${ }^{128}$ Cf. Id. Ibid., p. 66-67.
} 


\section{CARACTERIZAÇÃO DA DEPENDÊNCIA ECONÔMICA}

Diante dos objetivos do presente estudo, urge tratar, ainda que de forma superficial, dos elementos para caracterização da dependência econômica no âmbito contratual. É o que se passa a fazer.

\subsection{Surgimento da noção de dependência econômica no âmbito contratual}

Face ao fenômeno da necessária concentração de capital e de distribuição de massa que tem se verificado nas três últimas décadas, a constatação da situação de dependência econômica suportada por alguns profissionais era de rigor ${ }^{129}$. Concebida de início como uma proteção dos fabricantes contra o abuso empregado pelos grandes varejistas, a noção foi essencialmente utilizada pelos distribuidores para conter as manobras de seus fornecedores.

A noção de abuso de dependência econômica surgiu nos ordenamentos de alguns países europeus, que viam a necessidade de se criar uma nova figura capaz de contemplar, ao mesmo tempo, a proteção dos abusos cometidos tanto em âmbito contratual, quanto concorrencial.

No direito alemão, a figura aparece pela primeira vez com a alteração promovida no ano de 1973 na Lei Antitruste daquele país, que introduziu o conceito para facilitar a caracterização da "posição dominante" em situações onde os pressupostos tradicionais da sua verificação não se encontravam presentes ${ }^{130}$. Atualmente, a disciplina da dependência econômica é estendida apenas às pequenas e médias empresas, e está prevista no parágrafo 20, 2, da GWB, segundo o qual “\$20 Diskriminierungsverbot, Verbot unbilliger

\footnotetext{
${ }^{129}$ BURNS explica que "many factors in our present business system undoubtedly contribute to, and in some cases, necessitate, large size and high degree of concentration. If bigness and concentration give cause for concern, it is not because of a failure to appreciate the material benefits wich we have derived from mass production or a failure to recognize the place of large-scale enterprise in the economic world. Rather, such concern stems from a deep-rooted sensibility of the need for maintaining adequate opportunities for the same kind of individual initiative, and adequate freedom for the same kind of business innovation, wich to a large extent have made possible the progress we have achieved" (BURNS, Joseph W. A study of the antitrust laws: their administration, interpretation, and effect. New York: Central Book Company, 1958. p. 349).

${ }^{130}$ Cf. FORGIONI, Paula Andréa. Contrato de distribuição. São Paulo: Ed. Revista dos Tribunais, 2005. p. 365.
} 
Behinderung. (1) Marktbeherrschende Unternehmen, Vereinigungen von miteinander im Wettbewerb stehenden Unternehmen im Sinne der $\$$ 2, 3 und 28 Abs. 1 und Unternehmen, die Preise nach $\S 28$ Abs. 2 oder $\S 30$ Abs. 1 Satz 1 binden, dürfen ein anderes Unternehmen in einem Geschäftsverkehr, der gleichartigen Unternehmen üblicherweise zugänglich ist, weder unmittelbar noch mittelbar unbillig behindern oder gegenüber gleichartigen Unternehmen ohne sachlich gerechtfertigten Grund unmittelbar oder mittelbar unterschiedlich behandeln. (2) 1Absatz 1 gilt auch für Unternehmen und Vereinigungen von Unternehmen, soweit von ihnen kleine oder mittlere Unternehmen als Anbieter oder Nachfrager einer bestimmten Art von Waren oder gewerblichen Leistungen in der Weise abhängig sind, dass ausreichende und zumutbare Möglichkeiten, auf andere Unternehmen auszuweichen, nicht bestehen. 2Es wird vermutet, dass ein Anbieter einer bestimmten Art von Waren oder gewerblichen Leistungen von einem Nachfrager abhängig im Sinne des Satzes 1 ist, wenn dieser Nachfrager bei ihm zusätzlich zu den verkehrsüblichen Preisnachlässen oder sonstigen Leistungsentgelten regelmäßig besondere Vergünstigungen erlangt, die gleichartigen Nachfragern nicht gewährt werden $(\ldots)^{m 131}$.

No direito francês, marcadamente influenciado pelo direito alemão, a noção foi inicialmente positivada com a ordenança de $1^{\circ}$ de dezembro de 1986 , relativa à liberdade dos preços e da concorrência. Seu art. $8^{\circ}$ dispunha que "est prohibée dans les mêmes conditions, l'exploitation abusive par une entreprise ou un groupe d'entreprises: (...) 2. de l'état de dépendance économique, dans lequel se trouve à son égard, une entreprise cliente ou fournisseur qui ne dispose pas de solution équivalente”. Atualmente, a disciplina da dependência econômica está prevista no art. L420-2 do código de comércio francês ${ }^{132}$, que

\footnotetext{
${ }^{131}$ Em modesta tradução: $§ 20$ Proibição de discriminação, proibição de criação de barreiras iníquas. (1) Empresas que controlam o mercado, associações de empresas concorrentes entre si no sentido dos $\S \S 2^{\circ}, 3^{\circ}$ e 28 , inciso 1 e empresas que praticam preços tabelados não poderão, numa relação comercial usualmente acessível a empresas similares, criar barreiras a outra empresa direta ou indiretamente, de maneira iníqua, ou dar-lhe, direta ou indiretamente, tratamento diferenciado perante empresas do mesmo tipo, sem motivo técnico justificado. (2) $\mathrm{O}$ inciso 1 deve ser aplicado também para empresas e associações de empresas, na medida em que delas dependam pequenas ou médias empresas como fornecedoras ou compradoras de um determinado tipo de mercadorias ou serviços comerciais, de maneira que não haja opções suficientes ou toleráveis para negociar com outras empresas. Deve-se presumir que um fornecedor de um determinado tipo de mercadorias ou serviços comerciais é dependente de um comprador no sentido da frase 1 se este comprador obtiver, junto a ele, regularmente, além dos descontos de praxe nos preços ou em outras remunerações de serviços, vantagens especiais não concedidas a outros compradores similares.

${ }^{132}$ Artigo L420-2 do código de comércio francês: "est prohibée, dans les conditions prévues à l'article L. 420-1, l'exploitation abusive par une entreprise ou un groupe d'entreprises d'une position dominante sur le marché intérieur ou une partie substantielle de celui-ci. Ces abus peuvent notamment consister en refus de vente, en ventes liées ou en conditions de vente discriminatoires ainsi que dans la rupture de relations commerciales établies, au seul motif que le partenaire refuse de se soumettre à des conditions
} 
basicamente repete o antigo art. $8^{\circ}$ da ordenança retro mencionada, mas introduz uma significativa mudança: ao não exigir mais a ausência de solução equivalente, o novo dispositivo acabou por ampliar sobremaneira a noção de dependência econômica no direito francês.

Também ao ordenamento italiano não escapou a previsão da dependência econômica. O art. $9^{\circ}$ da Lei $\mathrm{n}^{\circ}$ 192/98, que disciplina o contrato de subfornitura na atividade produtiva, dispõe que: "Abuso di dipendenza economica. - 1. È vietato l'abuso da parte di una o più imprese dello stato di dipendenza economica nel quale si trova, nei suoi o nei loro riguardi, una impresa cliente o fornitrice. Si considera dipendenza economica la situazione in cui un'impresa sia in grado di determinare, nei rapporti comerciali con un'altra impresa, un eccesivo squilibrio di diritti e di obblighi. La dipendenza economica è valutata tenendo conto anche della reale possibilità per la parte che abbia subito l'abuso di reperire sul mercato alternative soddisfacenti. 2. L'abuso può anche consistere nel rifiuto di vendere o nel rifiuto do comprare, nella imposizione di condizioni contratualli ingiustificatamente gravose o discriminatorie, nella interruzione arbitraria delle relazioni commerciali in atto. 3. Il patto attraverso il quale si realizzi l'abuso di dipendenza economica è nullo". Em que pese a inserção do conceito em lei específica (Lei $\mathrm{n}^{\circ}$ 192/98), ele pode ser aplicado a todos os contratos.

Já em Portugal, a disciplina do abuso de dependência econômica está contemplada, atualmente, no art. $7^{\circ}$ da Lei $n^{\circ} 18 / 2003$, o qual estabelece que: " 1 - é proibida, na medida em que seja susceptível de afectar o funcionamento do mercado ou a estrutura da concorrência, a exploração abusiva, por uma ou mais empresas, do estado de dependência económica em que se encontre relativamente a elas qualquer empresa fornecedora ou cliente, por não dispor de alternativa equivalente; 2 - pode ser considerada abusiva, designadamente: a) a adopção de qualquer dos comportamentos previstos no $n^{o} 1$ do artigo $4^{o}$; b) a ruptura injustificada, total ou parcial, de uma relação comercial estabelecida, tendo em consideração as relações comerciais anteriores, os usos reconhecidos no ramo da actividade económica e as condições contratuais estabelecidas. 3 - para efeitos da aplicação do $n^{o} 1$, entende-se que uma empresa não dispõe de alternativa equivalente quando: a) o fornecimento do bem ou serviço em causa,

commerciales injustifiées. Est en outre prohibée, dès lors qu'elle est susceptible d'affecter le fonctionnement ou la structure de la concurrence, l'exploitation abusive par une entreprise ou un groupe d'entreprises de l'état de dépendance économique dans lequel se trouve à son égard une entreprise cliente ou fournisseur. Ces abus peuvent notamment consister en refus de vente, en ventes liées ou pratiques discriminatoires visées à l'article L. 442-6". 
nomeadamente o de distribuição, for assegurado por um número restrito de empresas; e b) a empresa não puder obter idênticas condições por parte de outros parceiros comerciais num prazo razoável, que confiram uma influência preponderante na composição ou nas deliberações dos órgãos de uma empresa".

No direito brasileiro ainda não existe previsão expressa e literal sobre a repressão ao abuso de dependência econômica, mas sua disciplina, já há algum tempo também, pode ser extraída da análise conjunta de princípios previstos em diversos dispositivos esparsos pelo ordenamento ${ }^{133}$.

Saudada pela doutrina como inovação conceitual, o surgimento da noção de dependência econômica insere-se no bojo de uma época em que se buscava a moralização das relações econômicas. Essa noção, contudo, não surge de um vazio jurídico, podendo ser comparada a noções semelhantes, já existentes anteriormente, consagradas pelo direito positivo e destinadas a corrigir igualmente eventual desequilíbrio contratual.

Do direito econômico, dois foram os conceitos que deram origem ao de dependência econômica, quais sejam, o de abuso de poder econômico e o de posição dominante. Mas a comparação é também possível com certos conceitos essencialmente de direito civil e que evocam, igualmente, a idéia de desigualdade entre as partes, a saber: abuso de ignorância e coação moral - na França conhecida como violência moral. Convém, portanto, distinguir o conceito de abuso de dependência econômica dessas outras noções que lhe deram origem, a fim de se chegar a uma definição que esteja exatamente de acordo com seus critérios específicos.

Segundo SHIEBER, o poder econômico é o que resulta da posse dos meios de produção. Quando esses meios de produção, em certos setores da atividade, são dominados por um indivíduo ou um grupo de indivíduos, por uma empresa ou um grupo de empresas, evitando que outros deles também possam dispor, configura-se abuso de poder econômico $^{134}$.

\footnotetext{
${ }^{133}$ Dentre tantos outros, a vedação às cláusulas potestativas (artigo 122 do Código Civil), os conceitos de lesão (artigo 157 do Código Civil), enriquecimento sem causa (artigo 884 do Código Civil) e abuso de direito (artigo 187 do Código Civil), bem como a vedação ao aumento arbitrário de lucros (artigo 173, § $4^{\circ}$, da CF/88, e artigo 20, inc. III, da Lei $\mathrm{n}^{\circ}$ 8.884/94) são alguns dos princípios que, em certa medida, contemplam o conceito de dependência econômica no ordenamento brasileiro. Além desses, tal conceito foi evidenciado, ainda que não expressamente, no parágrafo único do artigo 473 do Código Civil, o qual exige aviso prévio para a denúncia unilateral nos contratos com prazo indeterminado em que pesados investimentos tiverem sido realizados por uma das partes para a execução do contrato.

${ }^{134}$ SHIEBER, Benjamin M. Abusos do poder econômico: direito e experiência antitruste no Brasil e nos EUA. São Paulo: Ed. Revista dos Tribunais, 1966. p. 3.
} 
Alguns autores, sob o argumento de que à posição de poder econômico de um dos contratantes corresponde a posição de dependência econômica do outro, acreditam ser possível a analogia para aplicação dos dispositivos relativos aos consumidores nas relações entre profissionais. Parte da doutrina, no entanto, alerta que, conquanto complementares, os conceitos de abuso de poder econômico e de dependência econômica não se confundem, não sendo cabível, portanto, a analogia ${ }^{135}$. Mas é inegável que, ainda que não sejam sinônimos, os dois conceitos estão intimamente interligados. Deve-se ter em mente, apenas, que o poder econômico é somente uma das possíveis fontes de dependência, restando evidente que a verdadeira fonte jurídico-concorrencial da coerção na relação entre parceiros comerciais é a dependência econômica ${ }^{136}$.

Cumpre esclarecer a essa altura que, segundo SECKLER, o abuso de dependência econômica se distingue, ainda, do de posição dominante. Este se caracteriza pelo “comportement adopté par une entreprise ou un groupe d'entreprises qui détient sur le marché un pouvoir absolu"137. Essa dominação pode ser individual ou coletiva e se manifesta sob a forma de uma situação de monopólio ou de uma concentração de poder econômico tal que a empresa ou grupo de empresas consiga impor suas condições aos concorrentes e aos parceiros comerciais (a influência é sobre todo o mercado, portanto). $\mathrm{O}$ abuso de dependência econômica, por outro lado, pode ser relativo, ou seja, não é preciso que a empresa detenha um poder absoluto sobre o mercado, mas apenas que abuse de seu poder econômico perante um parceiro comercial desprovido de alternativas ${ }^{138}$. Trata-se, nesse caso, de uma exploração abusiva de uma situação de inferioridade imposta por quem detém o poder econômico, em detrimento daqueles que não o possuem, numa relação contratual específica.

\footnotetext{
${ }^{135}$ Cf. SECKLER, Valérie. L'abus de dépendance économique. Memoire de Dea de Droit Privé de L’Université de Paris I (Pantheon - Sorbonne), 1991-1992. p. 5-6.

${ }^{136}$ Cf. SALOMÃO FILHO, Calixto. Direito concorrencial: as condutas. São Paulo: Malheiros Ed., 2003. p. 205.

${ }^{137}$ Cf. SECKLER, Valérie. op. cit., p. 7.

${ }^{138} \mathrm{~A}$ mensuração da quantidade de poder econômico que deve deter o agente para que ele possa estar em situação de superioridade em relação a um parceiro comercial, podendo abusar de sua dependência, é de extrema dificuldade, não existindo um critério objetivo para tanto. FIRST, FOX e PITOFSKY ressaltam que "there is no simple mathematical formula, no concentration ratio, no Herfindahl index, that can measure power, much less tell us at what level accumulation of power becomes socially and politically dangerous" (FIRST, Harry; FOX, Eleanor M.; PITOFSKY, Robert. Revitalizing antitrust in its second century: essays on legal, economic, and political policy. New York: Quorum Books, 1991. p. 250). Em virtude disso, a quantidade de poder necessário para que se caracterize posição dominante de um determinado agente econômico é presumida pela lei. Essa mesma mensuração, quando estamos no campo da dependência econômica, porém, que não está ligada ao mercado como um todo, mas em geral a alguns agentes específicos, não é possível.
} 
No direito civil, os dois conceitos acima mencionados - coação moral e abuso de ignorância - tratam igualmente da exploração abusiva de uma das partes sobre a inferioridade da outra, para tirar vantagem de uma situação criada pelo contrato. A coação moral, ou abuso de situação (como preferem alguns), verificar-se-á sempre que um dos contratantes exercer uma pressão sobre a vontade de outro indivíduo, de forma a compelilo a dar seu consentimento ${ }^{139}$. A presença desse elemento em um contrato dá origem à possibilidade de sua anulação por vício de consentimento ${ }^{140}$.

A mesma lógica fundamenta a sanção imposta ao contratante que se aproveita da ignorância alheia para tirar vantagens contratuais. Essa situação se verifica muitas vezes nos contratos de consumo, em que o consumidor, por ignorância de informações, acaba por celebrar um contrato que evidentemente lhe será desvantajoso. A sanção com base na ignorância de uma das partes, todavia, acaba por ser um critério muito subjetivo, o que levou o próprio sistema a determinar um critério objetivo para tanto, qual seja a presunção nos contratos de consumo da debilidade por parte do consumidor.

Essa objetivação do critério de ignorância, no entanto, acabou por excluir do quadro sancionatório a exploração que se verifica nos contratos entre profissionais, daí a necessidade de se criar uma nova solução, um novo conceito, capaz de abranger não só os contratos de consumo, mas também os contratos entre profissionais.

Tanto a noção de estado de necessidade quanto a noção de ignorância de uma das partes, mesmo não se tratando de consumidor, foi em muito contemplada com a recepção, pelo atual Código Civil, do instituto jurídico da lesão.

O Código Comercial de 1850 havia abolido a aplicação do instituto jurídico da lesão aos contratos celebrados entre comerciantes, por considerar que a busca pelo lucro, mesmo que exagerado, e a especulação eram da própria natureza de tais contratos. Já o Código Civil de 1916, erguido em cima do espírito individualista da época, simplesmente

\footnotetext{
${ }^{139}$ Cf. SECKLER, Valérie. op. cit., p. 8.

${ }^{140} \mathrm{O}$ vício de consentimento conhecido por coação apresentou grande importância no Direito Romano e, a despeito do alargamento de sua noção, que hoje se faz transparecer pelo conceito do estado de necessidade, sua aplicação é, nos dias de hoje, um tanto quanto escassa. Um dos únicos campos de aplicação em que ainda se pode notar uma tendência de avanço desse conceito é justamente o dos contratos de dependência. GUESTIN é categórico ao afirmar que "on observe cependant une tendance récente de la jurisprudence à faire application $d u$ vice du violence à la solution de litiges dans lesquels l'une des parties se trouve en situation de dépendance économique à l'égard de l'autre, dans des conditions telles qu'il lui est impossible de défendre ses intérêts lors de la négociation d'un contrat ou de sa révision. Il en est ainsi, non seulement dans le cas d'une subordination juridique, résultant d'un contrat de travail, mais aussi au cas de grave inégalité économique" (GUESTIN, Jacques. L'abus dans les contrats. Gazette du Palais, Paris, n. 19-20, p. 3-4, out. 1981).
} 
ignorou a lesão ${ }^{141}$. Tal instituto estava previsto, em pequenos aspectos, em algumas leis especiais, como a Lei de Proteção à Economia Popular, que cuidava precipuamente do aspecto da repressão penal à usura, e o Código de Defesa do Consumidor, que, ao prever a nulidade das cláusulas abusivas, tratava, sem dúvida, da repressão à prática de lesão, embora limitada aos contratos de consumo ${ }^{142}$. Foi somente com a entrada em vigor do Código Civil de 2002, portanto, que referido instituto voltou à tona.

Segundo o art. 157 do atual Código Civil "ocorre a lesão quando uma pessoa, sob premente necessidade, ou por inexperiência, se obriga a prestação manifestamente desproporcional ao valor da prestação oposta". Tal conceito, contudo, não é abrangente o suficiente para os fins a que se destina o presente estudo, conforme será abordado mais adiante.

Em virtude até mesmo dos conceitos que lhe deram origem, os quais, como visto, são oriundos tanto do direito econômico, quanto do direito civil, a noção de dependência econômica terá grande influência nas diversas relações contratuais que poderão surgir entre agentes com intensidades distintas de poder econômico, podendo gerar explorações oportunistas que deverão ser objeto de estudo e censura não apenas em âmbito contratual, mas também na seara concorrencial.

\subsection{Classificação da dependência econômica segundo Calixto Salomão Filho ${ }^{143}$}

CaliXto, ao tratar das hipóteses de negociação compulsória (dentre as quais destaca principalmente a venda casada) - onde se encontra sempre presente o elemento da coerção concorrencial -, analisa os tipos de dependência econômica que podem existir no mercado. Força convir, porém, que a dependência econômica pode existir independentemente das hipóteses de negociação compulsória. Em realidade, a existência da dependência possibilita a prática da negociação compulsória por parte do agente principal, mas a sua caracterização não deve estar a ela adstrita. Muitos casos há em que existe a dependência econômica, sem que isso signifique que o agente pratique alguma

\footnotetext{
${ }^{141}$ Cf. NEGREIROS, Teresa. op. cit., p. 178.

${ }^{142}$ Cf. THEODORO JR., Humberto. Comentários ao novo Código Civil: dos defeitos do negócio jurídico ao final do livro III. Rio de Janeiro: Forense, 2003. v. 3, t. 1, p. 223-224.

${ }^{143}$ Cf. SALOMÃ̃ FILHO, Calixto. op. cit., p. 204-224.
} 
modalidade de negociação compulsória, podendo, no entanto, exercer outros tipos de abuso.

Ressalta referido autor que a coerção concorrencial presume-se da presença de dependência. É ela teórica, caracterizada pela inexistência de alternativas econômicas objetivas - não é determinada a partir das preferências subjetivas de um determinado agente econômico, pouco importando se, no caso concreto, o agente se sentiu coagido ou não.

Aludida presunção, contudo, é relativa, mas a prova de que a coerção não existiu deve ser teórica e econômica, capaz de demonstrar que não existiu relação causal entre a dependência econômica e a realização (ou não-realização) do negócio jurídico pelo revendedor, distribuidor, consumidor ou concorrente em questão ${ }^{144}$.

Segundo o autor em comento, pode-se dividir as hipóteses de dependência econômica em absolutas e relativas. Há dependência absoluta quando a vinculação é de todos os agentes econômicos no mercado em tela, e, nas hipóteses de vinculação específica de apenas um determinado agente econômico (ou alguns deles), estar-se-á diante da dependência relativa.

\subsubsection{Dependência absoluta}

A dependência absoluta pode decorrer de três fatores distintos e independentes entre si. A primeira forma de coerção dá-se através do exercício do poder no mercado, tido como a prática decorrente do poder econômico como abuso de posição dominante ou ato tendente à dominação do mercado.

O poder econômico como abuso de posição dominante ocorre em duas situações de negociação compulsória. A primeira delas é a venda casada visando ao descumprimento de tabelamento de preços. O agente econômico que não puder aumentar seus preços por terem sido pré-fixados pelo Estado procurará fazê-lo indiretamente, por meio da venda conjunta de um produto cujo preço não é regulamentado, descarregando neste produto todo o sobrepreço de monopólio que não será exigido no setor regulamentado.

${ }^{144}$ Cf. SALOMÃO FILHO, Calixto. op. cit., p. 206. 
A outra hipótese é a prática de venda casada para permitir a discriminação de preços. Essa situação poderá ocorrer quando o produto principal e o produto secundário forem conexos em proporções variáveis, isto é, quanto maior a quantidade adquirida pelo agente do produto secundário, maior a importância que ele atribui ao produto principal. $\mathrm{O}$ exemplo utilizado pelo autor em comento é o da máquina fotocopiadora e do papel nela utilizado, isto é, quanto maior a quantidade de papel adquirida pelo consumidor, pode-se concluir que maior é a importância da máquina fotocopiadora para ele.

Como não é possível distinguir em um momento prévio qual o agente que irá atribuir maior utilidade ao produto principal, não se consegue fazer a discriminação de preços já nesse produto. Assim, para lograr diferenciar os consumidores, vincula-se a venda do produto principal à venda do produto secundário e atribui-se um preço competitivo ao primeiro e o sobrepreço monopolista ao segundo, fazendo com que aqueles que atribuem maior valor ao produto principal paguem indiretamente mais por ele, por meio da compra compulsória do produto secundário vendido a preço de monopólio.

Por conseguinte, a negociação compulsória só configurará abuso de posição dominante nas hipóteses em que, claramente, pela sua utilização, se tornar possível a obtenção de preços monopolistas diretamente e sem intermediários no mercado em consideração $^{145}$.

Já no que tange à negociação compulsória enquanto ato tendente à dominação de mercado, duas são as características que devem estar presentes. Em primeiro lugar, a efetiva coerção do consumidor ou do agente econômico em situação de dependência a adquirir o produto; e, em segundo, a intenção de, por meio desta conduta, eliminar os concorrentes do mercado, dominando-o integralmente. Por óbvio, essa intenção deve ser medida com dados objetivos que demonstrem a possibilidade concreta de se atingir a dominação. Via de regra, deve ser comprovada com a presença de dados estruturais, sobretudo barreiras à entrada, e a inexistência de outras justificativas para tal comportamento, como a eficiência econômica.

A segunda e talvez mais comum das formas de coerção decorre de situações de limitada informação do consumidor ou agente econômico. Essa prática é particularmente relevante no tocante às negociações compulsórias que se realizam por meio dos mercados secundários, como a venda casada, pois o empresário subordina a

${ }^{145}$ Cf. SALOMÃO FILHO, Calixto. op. cit., p. 222. 
venda de seu produto principal à venda dos produtos e/ou serviços secundários (como a prestação dos serviços de manutenção do produto principal, por exemplo), sem que o consumidor ou agente econômico disponha de conhecimentos suficientes para saber até que ponto essa vinculação dos produtos primários e secundários é necessária ou simplesmente expressa um abuso de dependência econômica por parte do empresário. $\mathrm{O}$ agente em situação de dependência sequer cogita os custos e a freqüência de manutenção no momento da aquisição do produto. $\mathrm{O}$ abuso, nesse caso, não decorre do poder no mercado, mas sim da insuficiência de informação, já que pode ser verificado mesmo quando o agente econômico ou consumidor desinformado não representar parcela expressiva da demanda por aquele bem.

A última forma de dependência absoluta está relacionada ao controle de compatibilidade com a rede e aos retornos crescentes de escala. Pode se dar de duas formas: (i) predação aberta, realizada através da introdução de um novo produto principal, sem relevante melhoria tecnológica, cujo único objetivo é a criação de incompatibilidades com os acessórios (produtos secundários) produzidos pelos concorrentes; e (ii) negociação compulsória, por meio da qual o agente econômico, ao introduzir um novo produto principal, com nova tecnologia - que realmente traga acréscimo de utilidade para o consumidor -, cria um produto acessório compatível tão somente com esse novo produto principal.

Nesta última hipótese, a venda casada deriva implicitamente da criação de incompatibilidades com os produtos dos concorrentes, pois

\footnotetext{
"não sobra ao consumidor [ou agente econômico em posição de dependência] outra escolha que não a aquisição do produto secundário do fabricante do produto primário. A intenção de eliminar a concorrência é, então, presumida"146.
}

\subsubsection{Dependência relativa}

A dependência relativa se verifica nas hipóteses em que um determinado agente ou grupo de agentes econômicos torna-se, por específicas relações negociais, vinculado à

${ }^{146}$ SALOMÃO FILHO, Calixto. op. cit., p. 213. 
empresa com que contratou, sem quaisquer possibilidades de escolha ${ }^{147}$. É esse tipo de dependência que interessa mais de perto ao presente estudo.

A primeira forma de dependência relativa é a dependência de sortimento. Decorre ela da necessária presença de um determinado produto na gama de bens oferecidos pelo empresário. A dependência pode ser de uma marca, de um grupo de marcas ou até mesmo da própria existência de um sortimento, sendo que, por não apresentarem um substituto razoável, não resta alternativa ao agente econômico que não comprar o bem mediante o pagamento do preço estipulado por seu produtor.

Uma segunda e mais comum forma de dependência relativa é a chamada dependência empresarial. Esta se caracteriza pelas relações contratuais - de direito ou de fato - de longa duração, que criam vínculos econômicos duradouros entre as partes. É a hipótese clássica dos contratos de fornecimento a longo prazo e, principalmente, dos contratos de distribuição ${ }^{148}$. Essa relação contratual duradoura é fonte inesgotável de dependência, uma vez que o contratante acaba por adaptar todo o seu negócio instalações, métodos de propaganda, contatos empresariais etc. - em função de seu parceiro comercial. Ademais, o investimento efetuado pelo agente econômico, nesse caso, constitui em grande parte um custo irrecuperável, pois se presta a agregar valor à reputação do produtor, e não à sua própria. Assim, em virtude do fato da reputação do distribuidor estar atrelada à do produtor, não há como aquele se desligar deste último, inexistindo, portanto, poder de escolha para ele ${ }^{149}$.

\footnotetext{
${ }^{147}$ Cf. SALOMÃO FILHO, Calixto. op. cit., p. 213.

${ }^{148}$ Cabe também mencionar um tipo de contrato que vem sendo bastante estudado no meio jurídico: os "contratos cativos de longa duração", que são considerados contratos de massa, cujo objeto é a prestação de serviços de essencialidade no mundo contemporâneo, tais como os contratos de seguro-saúde, de assistência médico-hospitalar, de previdência privada, de telefone, televisão a cabo etc., assim como os serviços públicos básicos, de fornecimento de água, luz e telefone. A catividade de tais contratos acaba por "escravizar" o consumidor, na medida em que, em maior ou menor grau, é dependente dos serviços oferecidos por essas empresas e seduzido pelas campanhas de marketing e pelo consumismo da sociedade contemporânea (Cf. KARAM-SILVEIRA, Marco Antonio. Contratos Cativos de longa duração: tempo e equilíbrio nas relações contratuais. In: MARQUES, Claudia Lima (Coord). A nova crise do contrato: estudos sobre a nova teoria contratual. São Paulo: Ed. Revista dos Tribunais, 2007. p. 484 e 489). Nesse tipo de relação, prolongada no tempo, é praticamente impossível que as partes tenham a capacidade de prever todas as possíveis circunstâncias futuras, preparando-se para todas as vicissitudes (Cf. KUHN, Adriana Menezes de Simão. op. cit., p. 479). Em grande parte, tais contratos têm em um dos pólos uma pessoa física. Mas é possível que sejam também firmados entre duas empresas. Nessa última hipótese, ainda que a hipossuficiência dos empresários não seja presumida, é possível que surjam abusos em decorrência de situações não previstas inicialmente pelas partes contratantes. Como os "contratos cativos de longa duração", porém, em geral não dizem respeito ao objeto central da atividade praticada pelo empresário (core business), a aplicação do CDC em tais casos é menos discutível e vem sendo, inclusive, comumente aceita pelos tribunais e principais doutrinadores nacionais.

${ }^{149}$ Cf. SALOMÃO FILHO, Calixto. op. cit., p. 216.
} 
Por fim, a última forma de dependência relativa é a denominada dependência conjuntural, que decorre de uma crise conjuntural, em geral de escassez. Assim, por exemplo, um fornecedor que adquira seu produto em um mercado internacional ver-se-á privado de sua atividade caso esse mercado internacional passe por uma crise de escassez momentânea, ao passo que um outro fornecedor que adquira um produto semelhante no mercado interno será dotado de um poder de mercado efêmero, enquanto durar a crise de escassez de seu concorrente, podendo se aproveitar da dependência, também efêmera, oriunda desse contexto. A dependência nesses casos, portanto, é sempre passageira ou conjuntural.

\subsection{Importância do reconhecimento da dependência econômica no âmbito contratual}

A noção de dependência econômica no âmbito contratual foi amplamente estudada por VIRASSAMY ${ }^{150}$, que buscou mostrar que a característica de desigualdade existente em grande parte das relações contratuais modernas não se limita aos contratos entre consumidores e profissionais, nem mesmo às relações entre empregadores e assalariados, em que existe por definição um liame de subordinação jurídica entre as partes; mas sim que tal desigualdade pode ser observada freqüentemente entre parceiros profissionais e juridicamente independentes. Ela resulta, em verdade, do estado de dependência econômica no qual se encontra uma das partes em relação à outra.

O direito contratual, por muito tempo, foi baseado em um postulado fundamental: a autonomia da vontade, em razão da qual se justificava a força obrigatória do contrato. A evolução atual do direito das obrigações, contudo, vai de encontro às conseqüências desse princípio, de maneira que a tendência nos dias de hoje é a relativização de referido postulado.

De fato, o direito positivo deve deixar de lado a visão arcaica dos contratantes livres, iguais e soberanos em suas discussões contratuais. Deve-se levar em conta, atualmente, a desigualdade de suas condições e, particularmente, as suas diferenças de posição econômica, fontes de desequilíbrio contratual e de dominação de um parceiro sobre o outro.

\footnotetext{
${ }^{150}$ VIRASSAMY, Georges J. Les contrats de dépendance: essai sur les activités professionnelles exercées dans une dépendance économique. Paris: L.G.D.J, 1986.
} 
A primeira atitude tomada em virtude dessa constatação consistiu em se reduzir a liberdade contratual das partes, impondo-se restrições sobre a forma de suas convenções e, sobretudo, no que tange ao conteúdo de suas cláusulas. Posteriormente, a disparidade de condições das partes levou tanto o legislador, como a jurisprudência e a doutrina a destinar uma grande atenção ao período pré-contratual, durante o qual foi imposta ao profissional uma obrigação de informação.

O termo contratos de dependência, por mais original que possa soar, não deve ser confundido com uma categoria nova de contratos que vem ganhar espaço entre aqueles que já são objeto de qualificação e classificação pelo legislador e doutrina. Ele designa, na verdade, um grupo de contratos cada vez mais freqüente nas relações entre profissionais, já familiares ao jurista, pelos quais se estima ser necessário abandonar os métodos clássicos de análise contratual, para dar lugar preponderantemente às relações reais entre as partes, à prática do contrato e, sobretudo, às condições econômicas nas quais elas são levadas a contratar.

É preciso, portanto, estabelecer uma conformidade entre direito e fato (como diriam alguns, moralizar as práticas contratuais na vida profissional), tomando-se em consideração um fato essencial: a desigualdade das partes e as consequiências dela decorrentes.

A importância e a utilidade da noção de dependência econômica é, principalmente, a de permitir, por seu intermédio, a distinção, entre todos os outros, dos contratos regidos por atividades profissionais exercidas em situação de subordinação, a fim de lhes submeter mais rigorosamente às exigências da boa-fé e da lealdade contratual, assim como dos outros princípios contratuais, e, eventualmente, conceder-lhes o mesmo regime tutelar que é atribuído aos contratos de consumo.

\subsection{Diversidade dos contratos de dependência econômica}

Se a noção de contratos de dependência é relativamente nova na terminologia jurídica, deve-se esclarecer que ela não passa de uma realidade, uma experiência do mundo dos negócios, e, mais especificamente, da vida contratual. Ademais, embora não corresponda a uma reunião monolítica de contratos sujeitos a um corpo de regras jurídicas idênticas, a diversidade entre eles não pode mascarar a existência de uma verdadeira 
unidade de fato. E justamente em decorrência de tal unidade, é importante buscar seus elementos comuns, a fim de se permitir a caracterização dos contratos de dependência.

A diversidade dos contratos de dependência pode ser demonstrada pelo simples fato dessa categorial contratual não se limitar a algum setor da economia, mas, pelo contrário, ser largamente utilizada, sem qualquer limitação. É possível encontrar contratos de dependência nos três setores chave do âmbito negocial, quais sejam, o da produção, o da distribuição e o da prestação de serviços. São contratos de dependência, por exemplo, os contratos de trabalho, de concessão, de franquia, de agência comercial, de fornecimento, dentre tantos outros.

Como será visto, porém, a natureza da subordinação existente no contrato de dependência nem sempre é igual, sendo esse o critério que, basicamente, distingue entre um contrato de trabalho e um contrato de distribuição, por exemplo, já que ambos, em geral, por definição, integram a categoria dos contratos de dependência.

\subsection{Caracterização da dependência econômica segundo os critérios de Georges J. Virassamy}

VIRASSAMY $^{151}$, analisando a dependência econômica no âmbito contratual, chega à conclusão de que um contrato utilizado no mesmo setor de atividade e de natureza jurídica idêntica à de outro contrato pode revelar a categoria dos contratos de dependência, ao passo que o outro não. Faz-se necessário, dessa forma, precisar o critério de distinção de referidos contratos, o que será possível por meio do reconhecimento das características comuns dos contratos de dependência.

Algumas dessas características comuns a todos os contratos de dependência não são estranhas, pois estes são, em geral, contratos sucessivos e de adesão. Assim, grande parte dos efeitos que decorrem dessas categorias contratuais é também observada nos contratos de dependência.

O contrato sucessivo ${ }^{152}$ é habitualmente definido como aquele em que:

\footnotetext{
${ }^{151}$ VIRASSAMY, Georges J. op. cit.

${ }^{152}$ ORLANDO GOMES trata da distinção entre contratos instantâneos e contratos de duração, termo que acredita ser mais adequado do que contratos sucessivos. A conceituação dos contratos de duração segundo esse autor, porém, não é unívoca. As hesitações da doutrina começam já na própria denominação dessa
} 
“(...) as duas partes, ou uma delas, estão adstritas ao cumprimento de prestações contínuas ou repetidas em intervalos estipulados, por tempo determinado ou indeterminado. (...) A obrigação é única; fracionam-se as prestações" $" 153$.

A distinção entre contratos de execução única e contratos sucessivos ou de duração é de considerável interesse, uma vez que, nos contratos instantâneos, a resolução por inexecução faz as partes retornarem ao status quo ante, enquanto que, nos contratos sucessivos, os efeitos produzidos não são atingidos. Ocorre a mesma singularidade em relação à anulação, ao menos quando as prestações satisfeitas não puderem ser restituídas, como, por exemplo, o serviço prestado pelo empregado no contrato de trabalho. Diz-se, diante desse fato, que vigora o princípio da irretroatividade a respeito dos contratos de duração, explicável pelo fato de que os atos singulares de execução são juridicamente autônomos. A prescrição da ação para exigir o cumprimento de prestações vencidas, nos contratos de duração, começa a correr da data do vencimento de cada prestação. Finalmente, a resolução do contrato, ou o reajustamento de suas prestações, por força de circunstâncias imprevisíveis que acarretem onerosidade excessiva para uma das partes não tem cabimento nos contratos instantâneos, salvo os de execução diferida ${ }^{154}$. Em síntese, a teoria da imprevisão aplica-se ordinariamente aos contratos sucessivos ${ }^{155}$.

Os contratos de dependência são também freqüentemente contratos de adesão, o que equivale a dizer que no contrato

“(...) uma das partes tem de aceitar, em bloco, as cláusulas estabelecidas pela outra, aderindo a uma situação contratual que se encontra definida em todos os seus termos. O consentimento manifesta-se como simples adesão a conteúdo preestabelecido da relação jurídica" ${ }^{156}$.

Para que se caracterize o contrato de adesão, contudo, não basta que a relação jurídica se forme sem prévia discussão, aderindo uma das partes à vontade da outra, haja

categoria contratual, estendendo-se à delimitação e à diferenciação de subespécies. A figura é mais conhecida pelo nome de contrato de trato sucessivo, mas há quem prefira denominá-la de contrato de execução continuada, havendo quem os designe pela expressão contratos de débito permanente para contrapô-los aos de obrigação transitória (Cf. GOMES, Orlando. Contratos. 17. ed., Rio de Janeiro: Forense, 1997. p. 79).

${ }^{153}$ Id. Ibid., p. 80.

${ }^{154}$ Os contratos de execução diferida são contratos de execução única, ou seja, podem ser executados de uma só vez, em um só momento, mas, ao invés dessa execução se dar imediatamente após a sua conclusão, ela é protraída para outro momento (Cf. Id. Ibid., p. 81).

${ }^{155}$ Cf. Id. Ibid., p. 80-81.

${ }^{156}$ Id. Ibid., p. 109. 
vista que muitos contratos se estipulam desse modo sem que devam ter por isso essa qualificação. A grande peculiaridade do contrato de adesão propriamente dito é a circunstância de que a parte a quem ele é proposto não tem a opção de não contratar, porque tem necessidade de satisfazer a um interesse que, por outro modo, não poderia ser atendido $^{157 \text { e } 158 .}$

A principal característica dos contratos de dependência, porém, é, por óbvio, a própria dependência econômica. Mas, para que esta reste caracterizada, alguns elementos na relação entre as partes, suscitados por VIRASSAMY ${ }^{159}$, são fundamentais, conforme será exposto nos três itens subseqüentes.

\subsubsection{Elementos estruturais}

Antes de tudo, para a caracterização do estado de dependência, é preciso que haja uma relação contratual. Essa exigência limita o número de pessoas para as quais e em favor das quais o estado de dependência poderá produzir seus efeitos.

Porém, ser parte em um contrato ainda não é suficiente para que se configure o estado de dependência. Faz-se necessário que essa relação contratual apresente uma real importância para a existência ou sobrevivência de uma das partes. Toda a questão gira em

\footnotetext{
${ }^{157}$ GOMES, Orlando. op. cit., p. 119.

${ }^{158}$ Há algumas diferenças entre os contratos de adesão, por adesão ou contratos tipo. O contrato por adesão é um contrato com as mesmas características do contrato de adesão, havendo, contudo, outras opções para que o aderente obtenha as vantagens em razão das quais celebrou o contrato. No contrato tipo, por sua vez, muito embora suas cláusulas sejam preparadas por apenas uma das partes, podem ser negociadas pela parte contrária também, de forma que, no momento da celebração do contrato, a redação final deste pode ser produção de ambas as partes. Já o contrato de adesão apresenta, necessariamente, três fatores que o caracterizam, quais sejam: a rigidez, a pré-determinação e a uniformidade. Além disso, inexiste opção a uma das partes, que é obrigada a contratar mesmo diante da imposição de todas as cláusulas pela parte contrária (Cf. FERNANDES, Marcelo Cama Proença. O contrato de franquia empresarial. São Paulo: Memória Jurídica Editora, 2003. p. 47-48). TERESA NEGREIROS entende que o fato das cláusulas não serem previamente negociadas não é o traço fundamental dos contratos de adesão. O que realmente caracteriza tal tipo de contrato é a circunstância daquele a quem ele é imposto não poder deixar de contratar, pois não conseguiria satisfazer seu interesse por outro modo. Nesse sentido, o aderente não seria livre sequer para determinar se quer ou não contratar, ao contrário do que muitos autores afirmam (Cf. NEGREIROS, Teresa. op. cit., p. 373). Apesar dessa discussão doutrinária, contudo, o presente estudo não fará qualquer distinção entre os contratos de adesão e aqueles por adesão, já que o legislador também não os diferenciou. Será utilizada, prioritariamente, a terminologia "contratos de adesão", uma vez que este é o termo utilizado no Código Civil e no CDC.

${ }^{159}$ VIRASSAMY propõe uma definição de dependência econômica baseada em três elementos estruturais extraídos da definição dada por D. CUCHE para os contratos de trabalho, segundo o qual a dependência econômica "qui existerait lorsque celui qui fournit le travail en tire son unique ou principal moyen d'existence, et que celui qui en bénéficie absorbe intégralement et regulièrement l'activité du travailleur" (D. CUCHE apud VIRASSAMY, Georges J. op. cit., p. 133).
} 
torno de se saber a partir de qual limite o vínculo contratual será capaz de gerar uma dependência econômica, portanto.

Trata-se, em verdade, de uma questão de circunstância, isto é, caberá à jurisprudência decidir em cada caso concreto se restou deflagrada a importância vital do contrato para uma das partes, o que será feito em função dos elementos de prova fornecidos por ambas as partes. Como exemplo, se a parte mais fraca no contrato exercer uma atividade anexa, paralelamente à atividade por conta de seu contratante principal, capaz de lhe fornecer todos os meios suficientes a sua existência e sobrevivência, a jurisprudência deverá se recusar a lhe considerar como economicamente dependente de seu parceiro privilegiado e de lhe aplicar os efeitos do status protetor do dependente econômico.

A dependência econômica supõe, enfim, que as relações contratuais apresentem um caráter durável e permanente; que as atividades da parte mais fraca sejam organizadas em torno de e em função dessas relações. Ela não poderá existir, ao revés, se a relação não tem mais que um caráter passageiro, acidental ou ocasional, ainda que essencial ou que a totalidade da produção de um fabricante seja comprada por um único cliente.

Em resumo, é a conjugação desses três fatores - a saber, a existência de um vínculo contratual, a importância deste para o contratante e a permanência ou regularidade das relações entre as partes - que enseja a dependência econômica.

A dependência econômica, contudo, não resulta simplesmente do fato de o contrato ter se tornado o meio essencial de sobrevivência da atividade desempenhada por um dos contratantes, sendo freqüentemente organizada e reforçada pelas partes - por uma delas, em geral. Referidos elementos de reforço, que podem ser voluntários das partes (ou de uma delas) ou objetivos, serão pormenorizados a seguir.

\subsubsection{Elementos objetivos de reforço da dependência econômica}

O elemento de reforço da dependência econômica involuntário mais importante é a própria natureza do produto fabricado ou comercializado, particularmente se bastante procurado pela clientela. Isso porque, nesse caso, o proprietário da marca do produto encontrar-se-á em posição de superioridade que lhe permitirá sujeitar os distribuidores as 
suas condições. A clientela procura antes de tudo pela marca, mais do que pelo produto ${ }^{160}$. Assim, o distribuidor dos bens e serviços de determinada marca estará em completa dependência do proprietário desta. É o que ocorre, por exemplo, no contrato de franquia, em que o sucesso empresarial do franqueado depende, em grande medida, da força econômica que a marca do franqueador desfruta no mercado.

Um outro aspecto da natureza do produto que influi sobre a dependência econômica de um dos contratantes em relação ao outro concerne à característica perecível deste, ou seja, à impossibilidade de seu estocamento. Nesse caso, a situação fica ainda mais delicada, pois os pequenos empresários não têm condições de conservar os produtos perecíveis, o que torna qualquer tentativa de resistência às condições impostas pelo outro contratante um verdadeiro suicídio. Ademais, qualquer decisão de troca de parceiro comercial não pode ser tomada de imediato, porquanto os produtos já adquiridos para posterior distribuição devem ser distribuídos em um período de tempo muito curto.

A dependência econômica pode ainda ser reforçada quando uma das partes deve assumir encargos dos quais não poderá se subtrair, o que eqüivale a dizer que, pelo contrato, uma das partes acaba se sujeitando a custos econômicos que não teria condições de suportar por si só. Assim, em eventual ruptura do contrato, é provável que aludida parte ainda não tenha conseguido compensar os custos econômicos inicialmente despendidos.

Além desses três elementos que independem da vontade das partes, quais sejam a busca da marca pela clientela, a natureza perecível do produto e os custos econômicos suportados por uma delas, outros elementos, impostos por uma das partes à outra, também têm o condão de influenciar o estado de dependência econômica do contrato.

\subsubsection{Elementos contratuais de reforço da dependência econômica}

No momento da conclusão do contrato, a parte mais fraca se vê contraída a aceitar algumas estipulações que podem não almejar necessariamente reforçar a dependência

\footnotetext{
160“ O consumidor, vítima de sua própria incapacidade crítica ou susceptibilidade emocional, dócil objeto de exploração de uma publicidade obssessora e obsidional, passa a responder ao reflexo condicionado da palavra mágica, sem resistência. Compra um objeto ou paga por um serviço, não porque a sua marca ateste a boa qualidade, mas simplesmente porque ela evoca todo um reino de fantasia ou devaneio de atração irresistivel. Nessas condições, a distância que separa esse pobre Babbit do cão de Pavlov torna-se assustadoramente reduzida" (COMPARATO, Fabio Konder. A proteção do consumidor: importante capítulo do direito econômico. Revista de Direito Mercantil, Industrial, Econômico e Financeiro, São Paulo, n. 15/16, p. 93, 1974).
} 
econômica, mas que acabam por produzir esse resultado. Trata-se principalmente da duração do contrato, da estipulação de uma cláusula de exclusividade e, finalmente, de cláusulas pós-contratuais restritivas de liberdade.

A duração do contrato, durante muito tempo, foi motivo de preocupação dos trabalhadores assalariados, uma vez que a estipulação de um prazo indeterminado facultava ao empregador resilir unilateralmente o contrato a qualquer momento. Os empregados sob essa condição, portanto, viviam sob o constante risco de, a qualquer tempo, perderem o emprego.

Com a evolução da teoria contratual e dos direitos protecionistas do ente mais fraco, a tendência passou a ser justamente a inversa. Atualmente, observa-se uma preocupação muito maior nos contratos com prazo determinado. Isso porque, com a regulamentação dessa faculdade de resilição unilateral, os contratos a prazo indeterminado passaram a ser dotados de uma proteção eficaz à parte mais fraca.

A insegurança nos dias de hoje, desse modo, gira em torno da duração dos prazos contratuais, pois, por meio de um prazo excessivamente curto, o parceiro privilegiado busca manter seu parceiro sob constante pressão, com o objetivo de que este seja estimulado dia-a-dia a aumentar seus esforços para lograr obter a renovação do contrato. Já ao estipular um prazo muito longo, o contratante principal mantém seu parceiro a ele atrelado por muito tempo, rompendo qualquer tipo de contato deste último com o resto do mercado. A ruptura do contrato por parte do parceiro mais fraco, com isso, torna-se muito arriscada, já que, sem contatos no mercado, será muito difícil iniciar um novo empreendimento. Tanto num caso como noutro, a dependência econômica será reforçada, portanto.

Da mesma forma, a cláusula de exclusividade também leva ao reforço da dependência econômica, uma vez que esta conduz necessariamente à retirada da parte submissa a tal restrição do mercado e, de uma maneira geral, da vida contratual exterior às relações assim estabelecidas.

Por derradeiro, como se não bastassem as retro mencionadas hipóteses, a dependência pode ser ainda reforçada quando a liberdade dos contratantes advinda da ruptura do contrato for limitada por estipulações convencionais, como a cláusula de nãoconcorrência ou a de não-reorganização. Elas têm por efeito direto o de limitar ou até 
mesmo suprimir a liberdade econômica da parte a elas submetida, impedindo-a de se ver livre para prosseguir na atividade desejada.

Levando ao último extremo a restrição da liberdade imposta por essas cláusulas, podemos chegar à situação da total impossibilidade de manutenção da atividade por parte do contratante sujeito a seu cumprimento ou até mesmo do desemprego. Justamente por isso que a jurisprudência submeteu a validade de tais cláusulas a um compromisso de que elas sejam limitadas no tempo, no espaço ou quanto a seu objeto ${ }^{161}$.

Diante do exposto, resta claro que a dependência econômica pode ser reforçada por elementos impostos por uma das partes à outra, dentre os quais destaca-se o prazo contratual, a estipulação de uma cláusula de exclusividade e de cláusulas póscontratuais restritivas de liberdade.

\subsection{Conseqüência direta da dependência econômica: a subordinação}

Os contratos de dependência econômica são, como visto, muito variados, tanto na concepção e na finalidade, quanto pela natureza jurídica. A despeito dessa diversidade, eles são ligados por um elemento que lhes é comum: a dependência de um dos contratantes, conforme os critérios acima evidenciados.

Uma análise mais profunda desses contratos permite constatar que essa dependência tem grande influência na natureza das relações entre as partes. De acordo com o contrato, a parte mais fraca será mais ou menos livre para conduzir a seu modo suas atividades, situação que é marcada por sua subordinação ao parceiro privilegiado.

Independentemente de sua qualidade, trabalhador/empresário dependente ou independente, ou da natureza jurídica do vínculo que lhe une a seu contratante, todos os contratos de dependência conduzem a essa subordinação, corolário direto da dependência

\footnotetext{
${ }^{161}$ GUESTIN explica que "l'insertion d'une telle clause constitue l'exercice d'un droit, mais l'exercice de ce droit est abusif s'il a pour effet d'empêcher l'intéressé d'exercer le métier qui est le sien. C'est pourquoi cet engagement est normalement limité à un secteur géographique et à une durée déterminée". O mesmo autor ainda acrescenta que a jurisprudência, nos dias de hoje, admite "qu'une clause de non-concurrence est, en principe, licite, et qu'elle ne doit être annulée que dans la mesure où elle porte atteinte à la liberté du travail en raison de son étendue dans le temps et dans l'espace et quant à la nature de l'activité de l'intéressé. (...) On observera que si la clause de non-concurrence est admise dans son principe, c'est l'usage abusif de ce droit qui est éliminé par la jurisprudence" (GUESTIN, Jacques. op. cit., p. 5).
} 
econômica de uma das partes. Tal subordinação, contudo, nem sempre é igual, variando de intensidade conforme a sua natureza, se jurídica ou profissional.

\subsubsection{Subordinação jurídica}

A subordinação jurídica resulta da própria natureza do contrato, não dependendo, portanto, da convenção das partes e/ou das cláusulas aceitas por uma delas a pedido da outra, tendo como exemplo típico o contrato de trabalho. As cláusulas do contrato definem unicamente as conseqüências dessa subordinação, o que levou alguns autores a afirmar que nesses tipos de contrato há subordinação de direito.

O contratante dependente é obrigado a se sujeitar à autoridade do outro contratante, sob pena de responsabilização e/ou ruptura contratual, daí ter a doutrina francesa designado tais contratos por contratos de dependência a subordinação perfeita ${ }^{162}$.

\subsubsection{Subordinação profissional}

A subordinação profissional, por outro lado, resulta da imposição de algumas cláusulas pela parte economicamente mais forte. Nesse caso, a subordinação decorre apenas da situação de fato de dependência econômica de um dos contratantes, não sendo reforçada pelo próprio direito. Tais contratos foram, então, denominados pela doutrina francesa como contratos de dependência a subordinação imperfeita ${ }^{163}$. Citando novamente o mesmo exemplo já abordado, esse é o caso dos contratos de franquia, onde os franqueados são considerados agentes comerciais juridicamente independentes, mas subordinados profissionalmente ao franqueador.

Para garantir o futuro econômico de seus contratantes, o parceiro privilegiado dispõe de um meio de lhes impor uma estratégia econômica e comercial que leva em conta seus próprios interesses. Essa dominação resulta da racionalização das relações contratuais por uma série de cláusulas fixadas com base na extensão de seu poder sobre seus

\footnotetext{
${ }^{162}$ Cf. VIRASSAMY, Georges J. op. cit., p. 154.

${ }^{163}$ Cf. Id. Ibid., p. 160.
} 
contratantes. Essas estipulações podem ser divididas em duas categorias: as cláusulas de sujeição e as de controle.

Pode-se citar como cláusulas de sujeição, principalmente: a imposição da política de preços; a imposição das condições para a prática publicitária; a imposição de quotas (que, no exemplo acima mencionado, acarreta a transferência dos riscos do franqueador para o franqueado); o respeito às normas técnicas ${ }^{164}$; a obrigatoriedade da criação de serviços ao consumidor (serviços destinados à clientela); e as obrigações contábeis e financeiras particulares, que visam a manter a comunicação interna da situação financeira do parceiro economicamente mais fraco para o mais forte.

Dentre as cláusulas tidas como de controle, destacam-se: a obrigação de fornecimento de uma cópia do arquivo de clientes; o direito de visita e inspeção das instalações; a comunicação dos livros contábeis, balanço econômico e contas de operacionalização ao parceiro privilegiado; a imposição dos horários de funcionamento do fundo de comércio; a manutenção e gestão do pessoal; o agenciamento das instalações; e o controle sobre as parcerias financeiras e comerciais, sobre a forma jurídica da empresa e sobre a modificação do capital social.

Sendo perfeita ou imperfeita a subordinação, mais ou menos intensa, o fato é que essa classe de contratos caracteriza-se pela dependência econômica da parte mais fraca em relação ao parceiro privilegiado.

\subsection{Ordenança francesa de $1^{\circ}$ de dezembro de 1986: a caracterização do abuso de dependência econômica}

A importância para o presente estudo da análise desse já extinto preceito normativo do direito francês é marcante, pois não existe em ordenamento algum uma definição precisa sobre o abuso de dependência econômica. A própria ordenança francesa de $1^{\circ}$ de dezembro de 1986 não definia explicitamente este conceito, mas, como bem ressaltado por SECKLER ${ }^{165}$, era possível extrair de seu texto três condições para que se caracterizasse tal

\footnotetext{
${ }^{164}$ De maneira quase que sistemática, o parceiro mais fraco é obrigado a, no exercício de sua atividade, nortear-se pelas normas técnicas que condicionam a conformidade dos resultados obtidos às estipulações contratuais. É o caso dos franqueados, que devem aplicar rigorosamente as regras dos manuais que lhes são fornecidos pelo franqueador, por exemplo.

${ }^{165}$ Cf. SECKLER, Valérie. op. cit., p. 12.
} 
abuso, a saber: uma situação de dependência, uma exploração abusiva dessa situação e, finalmente, um efeito restritivo sobre a concorrência em decorrência da referida situação.

Para a caracterização da situação de dependência, ainda, referido texto legal apontava quatro elementos fundamentais, que serão tratados a seguir, os quais seguem a mesma linha dos elementos tratados acima por VIRASSAMY ${ }^{166}$.

\subsubsection{Situação de dependência}

A notoriedade da marca de propriedade do parceiro privilegiado é o primeiro deles. Esse elemento é particularmente importante para os distribuidores tendo em vista que é a marca que vai condicionar a demanda dos consumidores. Quanto maior a notoriedade da marca, maior o estado de dependência, pois mais dificilmente conseguirá o revendedor substitui-la para conseguir suprir o abastecimento dos consumidores a que se propôs.

O segundo elemento é a situação do fornecedor sobre o mercado de produtos. Com efeito, quanto maior a predominância do fornecedor no mercado, mais fácil será manter seus revendedores em situação de dependência, especialmente se ele se encontrar em estado de monopólio, quando não restará aos revendedores outra opção senão manter os negócios com seu parceiro.

O terceiro deles diz respeito à parcela dos produtos no montante dos negócios do revendedor. Isso quer dizer que quanto maior a parcela de produtos do parceiro privilegiado representar no volume dos negócios do revendedor, mais difícil será para este impor suas condições, com o medo de que aquele possa romper as relações, e, portanto, maior será sua dependência.

Por fim, o último elemento a ser considerado trata da exigência legal de ausência de solução equivalente, que era, na verdade, o único elemento expressamente formulado pelo art. $8^{\circ}$ da ordenança francesa de $1^{\circ}$ de dezembro de 1986. O estado de dependência caracteriza uma situação na qual uma empresa é obrigada a manter relações comerciais com outra empresa ou grupo de empresas, sendo-lhe impossível abastecer-se de produtos

\footnotetext{
${ }^{166}$ VIRASSAMY, porém, detalhou de forma mais precisa os elementos necessários para a caracterização da dependência econômica.
} 
substituíveis em condições equivalentes. Dada essa impossibilidade, o parceiro dependente perde ainda mais força para pleitear seus interesses face ao parceiro economicamente privilegiado.

\subsubsection{Exploração abusiva}

Uma vez estabelecida a situação de dependência, deve-se analisar em que medida o parceiro em posição de superioridade vai extrair vantagem de tal situação. O próprio art. $8^{\circ}$, em sua última alínea, listava, de forma não exaustiva, diversos exemplos do abuso dessa situação ${ }^{167}$.

Dentre os comportamentos reprimidos, é a ruptura das relações comerciais estabelecidas entre as partes que mais tem suscitado interesse por parte dos juristas. É também esse um dos melhores momentos para se analisar os critérios da definição dada por VIRASSAMY para os contratos de dependência. Isso porque a dependência econômica no momento da ruptura do contrato é caracterizada por diversos fatores: o fato de o parceiro em situação de inferioridade atribuir a totalidade ou boa parte de sua atividade a seu contratante; as condições da ruptura (notadamente em razão da duração do contrato); e a perda da clientela. Essa situação pode ser verificada principalmente nas cadeias de distribuição com forte integração, pois, nesses casos, a relação de dependência criada pelo contrato é acentuada ainda mais no momento da ruptura ${ }^{168}$.

Para que a análise da caracterização do abuso, uma vez estabelecida a situação de dependência, não seja puramente subjetiva, o art. $8^{\circ}$ acima mencionado a vinculava aos critérios de outro texto legal (a Lei Doubin). Assim, haveria abuso na ruptura das relações comerciais estabelecidas, conforme o artigo supra mencionado, sempre que as condições estabelecidas pela Lei Doubin no tocante às modalidades de ruptura não fossem respeitadas.

\footnotetext{
${ }^{167} \mathrm{O}$ abuso poderia consistir em recusa de venda, venda casada ou em condições de venda discriminatórias, bem como a ruptura de relações comerciais estáveis pelo exclusivo motivo de que o parceiro comercial recusou a se submeter a condições comerciais injustificadas.

${ }^{168}$ Curioso que a nova legislação francesa (art. L420-2 do código de comércio francês) não mais inclui de forma expressa a ruptura das relações comerciais estáveis dentre as condutas que poderiam caracterizar abuso de dependência econômica.
} 


\subsubsection{Efeito restritivo sobre a concorrência}

A exploração abusiva de um estado de dependência econômica, contudo, não é sancionada por si mesma, independentemente de seus efeitos sobre a concorrência. A sanção do abuso de dependência econômica deverá levar em conta os imperativos econômicos e comerciais que visem a uma concorrência equilibrada, sem paralisar as estruturas econômicas, nem constituir um freio à livre iniciativa.

Em matéria de distribuição, por exemplo, insta analisar essa influência sobre a concorrência no âmbito da organização interna de cada cadeia. O entrave à livre concorrência pode ser observado mesmo se a economia geral não for afetada, desde que, dentro da cadeia em questão, a repartição entre os revendedores da parte do mercado detida pela empresa dominante seja modificada em virtude da dependência econômica vivenciada por um deles. Essa condição de entrave à livre concorrência, portanto, deve ser subjetivamente apreciada em cada cadeia, levando-se em conta cada tipo de relação contratual existente. E, somente se houver um efeito negativo sobre a concorrência, é que poderá restar caracterizado o abuso da dependência econômica.

Tal efeito restritivo sobre a concorrência, porém, faz sentido quando da cogitação dos instrumentos concorrenciais de repressão à dependência econômica. Quando se está diante de um instrumento de repressão contratual, de contornos estritamente privatísticos, não parece rigorosamente necessária a ocorrência de um efeito restritivo sobre a concorrência para que haja um controle de uma situação de abuso verificada no caso concreto, daí porque os instrumentos do direito antitruste nem sempre são suficientes para se tutelar de maneira eficiente os abusos cometidos em relações contratuais, conforme se verá em capítulo específico. 


\section{DEPENDÊNCIA ECONÔMICA NO ÂMBITO CONTRATUAL E O CONCEITO DE CONSUMIDOR EQUIPARADO}

\subsection{Lógica do direito empresarial versus equiparação de empresário a consumidor}

Quando se trata da equiparação de empresários a consumidores, a grande questão é tentar entender se a aplicação do CDC aos contratos interempresariais poderia, de alguma forma, desvirtuar a lógica do direito empresarial.

O direito empresarial, como ramo autônomo do direito, surgiu em razão de necessidades especiais dos comerciantes/empresários, e evoluiu ao longo dos séculos introduzindo princípios peculiares que protegiam sua lógica própria.

Ainda que o aumento da complexidade das relações jurídicas e o surgimento de uma nova realidade social e econômica tenham demandado uma adaptação do direito comum, para a proteção dos abusos porventura surgidos, não se pode esquecer que o risco do negócio é pressuposto da atividade empresarial, e qualquer solução encontrada no ordenamento não pode ter por objetivo a exclusão desse risco, em detrimento da segurança jurídica que se espera das relações interempresariais.

Por outro lado, tal argumento, sob a ótica da justiça contratual, não pode trazer como conseqüência a ausência de respaldo legal do empresário economicamente dependente contra os abusos praticados pelo contratante em posição de superioridade.

É o que se passa a tratar.

\subsubsection{Evolução da teoria contratual}

A idéia clássica de contrato surgiu como um elemento fundamental de expressão do momento pelo qual passava a civilização européia. Buscando-se superar as estruturas vinculadas às monarquias absolutistas, foram criados instrumentos próprios à efetivação do poder da ascendente burguesia. Isso se viabilizou por meio do desenvolvimento de 
institutos que privilegiavam a idéia da ampla autonomia da vontade e tinham como pressuposto a rígida igualdade das partes que negociavam ${ }^{169}$.

Os princípios fundamentais que regiam os contratos eram a autonomia da vontade que protegia o princípio geral da liberdade de contratar, segundo a autodeterminação da vontade $^{170}$-, a força obrigatória do contrato - que estabelecia que, uma vez pactuado de forma livre e válida, o contrato tornava-se lei entre as partes $^{171}$-, a relatividade dos efeitos contratuais - que determinava que as normas que emanavam do contrato só produziriam efeitos entre as partes, não prejudicando nem aproveitando a terceiros -, e a boa-fé - que, além de impor limites à liberdade contratual, era fonte criadora de direitos e deveres secundários, os quais regiam a conduta das partes antes, durante e depois da vigência do contrato.

O princípio da boa-fé surgiu como contrapeso aos dois primeiros princípios, sustentando o dever das partes agirem conforme a economia e a finalidade do contrato, de modo a conservar o equilíbrio substancial e funcional entre as obrigações correspectivas que haviam formado o sinalagma contratual ${ }^{172}$.

A partir do século XVIII, e especialmente com a Revolução Francesa, porém, quando a teoria clássica do contrato teve seu grande desenvolvimento, o princípio da boafé ficou como que esquecido no mundo contratual. Objetivando acabar com o discrímen estamental existente naquela época, a teoria contratual passou a se basear na igualdade formal entre as partes e a exigir uma liberdade contratual extremada, somente limitada pelas leis de ordem pública e pelos bons costumes, que, devido ao subjetivismo, não eram capazes de impedir os abusos.

De fato, com a Revolução Industrial e Comercial, a sociedade burguesa passou a buscar, antes de tudo, segurança e eliminação de riscos, o que vinha a calhar exatamente com a concepção individualista das teorias que consagraram a força obrigatória do contrato e a autonomia da vontade. É justamente por isso que "a primazia da autonomia da vontade

\footnotetext{
${ }^{169}$ Cf. SCAFF, Fernando Campos. As novas figuras contratuais e a autonomia da vontade. Revista da Faculdade de Direito da Universidade de São Paulo, São Paulo, v. 91, p. 142-143, 1996.

${ }_{170 "} O$ conceito de liberdade de contratar abrange os poderes de auto-regência de interesses, de livre discussão das condições contratuais e, por fim, de escolha do tipo de contrato conveniente à atuação da vontade" (GOMES, Orlando. op. cit., p. 22).

${ }^{171} \mathrm{~A}$ exceção a este princípio encontra-se na teoria da imprevisão, pela qual, em situações extremamente graves, onde há quebra do sinalagma inicial e conseqüente frustração da função econômica e social do contrato, além da álea normal que marca o mundo dos negócios, admite-se afastar a obrigatoriedade do pactuado.

${ }^{172}$ Cf. MELLO, Adriana Mandim Theodoro de. Franquia empresarial: responsabilidade civil na extinção do contrato. Rio de Janeiro: Forense, 2001. p. 17 e 32.
} 
é tida como resultante das mutações sócio-econômicas ocorridas na transposição do regime feudal para o liberalismo clássico"173.

A justiça contratual, nesse contexto, era assegurada pelo fato de o conteúdo do contrato corresponder à vontade livre dos contraentes, que, espontânea e conscientemente, o determinavam num plano de recíproca igualdade jurídica. Não havia lugar, portanto, para a questão da intrínseca igualdade e da justiça substancial das operações econômicas realizadas sob a forma contratual ${ }^{174}$.

O campo de atuação do magistrado na seara contratual, em tal época, era muito restrito. Tanto o legislador como o juiz deviam fiel observância ao que fora pactuado entre as partes, uma vez que estas tinham ampla liberdade quanto à fixação das obrigações que vonluntariamente se impunham e, nessa medida, o que era querido devia ser considerado obrigatório $^{175}$. A vontade, como centro do contrato, era soberana.

O modelo da teoria clássica do contrato, porém, muito similar ao modelo da teoria econômica liberal, baseado no princípio do laissez-faire, não tardou para demonstrar suas fraquezas. Constatou-se facilmente que a pretensa igualdade entre os contratantes constituía-se numa interpretação muito mais formal do que material ${ }^{176}$.

Em verdade, toda a construção da autonomia da vontade edificada pelos pensadores do século XIX partia de uma premissa equivocada: a igualdade formal. A consagração da liberdade plena na declaração de vontades, em uma sociedade repleta de desigualdades, não levava a uma realidade justa, tampouco se podia vislumbrar verídica liberdade na vinculação dos hipossuficientes ${ }^{177}$.

Mais do que isso, não só se provou que as partes que contratam não são iguais, como também, no curso da própria contratação, as expectativas e posições contratuais inicialmente previstas podem se alterar. As características dos contratantes são essenciais para se determinar a condição de barganha contratual que cada um tem. Não há como dizer que contratantes velhos ou jovens, saudáveis ou doentes, ricos ou pobres, empregados ou

\footnotetext{
${ }^{173}$ MELLO, Adriana Mandim Theodoro de. op. cit., p. 20.

${ }^{174}$ Cf. ROPPO, Enzo. O contrato. Coimbra: Almedina, 1988. p. 35.

${ }^{175}$ Cf. NEGREIROS, Teresa. op. cit., p. 27.

${ }^{176}$ Nesse sentido, TAVARES GUERREIRO afirma que "não tardou, porém, para que o liberalismo extremado e ilimitado revelasse sua ineficácia moral, engendrando, em manifestações no plano econômico, toda sorte de injustiças, em prejuízo do equilíbrio social" (GUERREIRO, José Alexandre Tavares. O Estado e a economia dos contratos privados. Revista de Direito Mercantil, Industrial, Econômico e Financeiro, São Paulo, n. 31, p. 77, 1978).

${ }^{177}$ Cf. MELLO, Adriana Mandim Theodoro de. op. cit., p. 22.
} 
desempregados, entre tantas outras variáveis, têm exatamente a mesma condição negocial $^{178}$.

Em vista disso, o contrato não pode representar, como a princípio se pretendia, norma insuperável sob a qual deveriam se submeter as partes, impossibilitando-se toda e qualquer modificação ${ }^{179}$.

Como muito bem acentuado por SENISE LISBOA, ao tratar dos contratos de adesão, a igualdade abstrata ou formal, por ser um pressuposto da liberdade para contratar, acaba muitas vezes por obscurecer a desigualdade real. Com efeito, nos contratos de adesão, é indiscutível que a liberdade negocial não se verifica na mesma intensidade para as duas partes contraentes e, como consequiência lógica, também a autonomia da vontade, ficando o aderente impossibilitado de proceder à determinação do conteúdo do contrato ${ }^{180}$. Os contratos de adesão em grande parte limitam as possibilidades de escolha do aderente e, como ressaltou PAULO LÔBO, “certamente a desigualdade real não seria considerada pelo direito se a disparidade de poder econômico pudesse ser contrabalançada por amplas possibilidades de escolha",181.

Assim, o contrato deixa, atualmente, de ser uma liberdade suprema, encontrando inúmeras limitações e restrições em sua função social, conforme será abordado a seguir.

AdrianA THEOdORO DE MELlo ressalta a existência de três ordens de preocupações que levaram o direito moderno a impor restrições à autonomia da vontade, a saber: (i) a constatação de que a expressão da vontade não é livre, quando à parte hipossuficiente ou economicamente vulnerável não é dada a liberdade de escolha, de contratar ou não contratar, ou de estabelecer as condições mínimas que preservem seus interesses tutelados pelo direito; (ii) o desenvolvimento das relações de massa que levaram a uma concentração inimaginável do poder econômico, sem lastro na democracia e no contrato social, que dotou poucos grupos privados do poder de comandar os desígnios de economias estatais inteiras; e, por fim, (iii) a verificação concreta de que o contrato é instrumento eficaz e indispensável à evolução e desenvolvimento estável da economia

\footnotetext{
${ }^{178}$ Cf. NEGREIROS, Teresa. op. cit., p. 311-313.

${ }^{179}$ Cf. SCAFF, Fernando Campos. op. cit., p. 144.

${ }^{180}$ Cf. LISBOA, Roberto Senise. Princípios gerais dos contratos. Revista dos Tribunais, São Paulo, v. 86, n. 745, p. 38, nov. 1997.

${ }^{181}$ LÔBO, Paulo Luiz Neto. Condições gerais dos contratos e cláusulas abusivas. São Paulo: Saraiva, 1991. p. 17.
} 
popular, à qualidade de vida social e ao desenvolvimento seguro e sustentado da sociedade $^{182}$.

Foi precisamente nesse contexto de valorização da função social do contrato e de sua concepção como instrumento finalístico de realização de operações econômicas guiadas por um sinalagma, que o princípio da boa-fé foi elevado à posição de limitador da autonomia da vontade ${ }^{183}$.

Em virtude dessa percepção, ainda, a teoria do abuso de poder econômico no mundo contratual passou a ter grande desenvolvimento, inspirando as limitações da liberdade contratual para atender às exigências sociais de desequilíbrio entre as partes ${ }^{184}$.

Ressalte-se, todavia, que, com a transposição da teoria clássica do contrato, não se está a mitigar o contrato em si, mas somente um modelo histórico de contrato. Não se verificou em virtude dessa transposição, ao contrário do que pensava GILMORE, a morte do contrato $^{185}$. O advento de novos valores, princípios e concepções contratuais, juntamente com a autonomia da vontade - que continua a existir, mas de forma limitada -, vai apenas influenciar uma nova teoria para o direito dos contratos ${ }^{186}$, que busca a moralização das relações contratuais por meio de uma verdadeira liberdade de contratar e cujo pressuposto, agora, é o desequilíbrio real entre as partes ${ }^{187}$.

As transformações ocorridas no mundo jurídico, de um modo geral, incluindo aí as tranformações no campo contratual, em especial a mitigação da autonomia da vontade e da

\footnotetext{
${ }^{182}$ Cf. MELLO, Adriana Mandim Theodoro de. op. cit., p. 24-25.

${ }^{183} \mathrm{Cf}$. Id. Ibid., p. 28.

${ }^{184}$ “A nova concepção do contrato é uma concepção social, em relação à qual não só o momento da manifestação de vontade importa, mas onde também e principalmente os efeitos do contrato na sociedade serão levados em conta na procura do equilíbrio contratual na sociedade econômica moderna, considerando a condição social e econômica dos contratantes" (Cf. COSTA, Maria Aracy Menezes da. op. cit., p. 228).

185“"The death of contract" foi a expressão utilizada por GRANT GILMORE em seu famoso livro: The death of contract. 2. ed. Columbus: Ohio State University Press, 1995. p 95-112.

${ }^{186}$ GUIDO ALPA esclarece que o conteúdo e a certeza dos princípios basilares do direito contratual não são pacíficos; alguns deles, aliás, são contraditórios entre si, tocando ao intérprete modelá-los, segundo a apreciação das circunstâncias. Tais princípios, além de caracterizarem uma época, são testemunhas da modificada (ou modificável) concepção do contrato, o qual passa de negócio particular àquela de regulamento submetido, efetivamente, a controle, integrações e modificações (Cf. ALPA, Guido. Princípios gerais e direito dos contratos: um inventário de dicta e de questões. In: MONTEIRO, António J. M. Pinto (Coord.). Contratos: actualidade e evolução. Porto: Coimbra Ed., 1997. p. 104).

${ }^{187}$ A esse teor, TAVARES GUERREIRO elucida que, “(...) a intervenção do Estado na economia dos contratos, objetivando estabelecer uma igualdade real e não apenas formal entre os contratantes, representa não um fator de decadência do instituto, mas, ao revés, um elemento positivo de equilíbrio nas prestações respectivas, o que não apenas é justo e moral, como também essencial à própria valorização do contrato como negócio jurídico voluntário. (...) Daí se pode dizer que, muitas vezes, o que se apregoa como decadência ou crise do contrato, nada mais é do que sua simples transformação conceitual, que, longe de desnaturá-lo, na verdade o aperfeiçoa, e o torna social e moralmente aceitável" (GUERREIRO, José Alexandre Tavares. op. cit., p. 79).
} 
força obrigatória dos contratos, fizeram com que JUNQUEIRA DE AZEVEDO, em artigo publicado na Revista dos Tribunais, chegasse a questionar a própria continuidade do direito civil ${ }^{188}$. Hoje, porém, tal autor é um dos juristas que mais tem contribuído para a sistematização dos novos princípios do direito civil.

TARTUCE vai mais além, ao concluir que não apenas o contrato não está em decadência, como inclusive vivencia o seu apogeu, devendo ser considerado instituto emergente e central de todo o Direito Privado, estando no centro das discussões do direito civil justamente em razão das profundas alterações pelas quais vem passando ${ }^{189}$.

Parte da doutrina defende que não se deve falar em novos paradigmas do contrato, pois as recentes transformações tiveram por objetivo apenas promover o melhor funcionamento do mercado. Tais transformações teriam ocorrido para acompanhar as alterações que se verificaram na sociedade, mas ao contrato continua sendo assegurada exatamente a mesma função que sempre lhe foi reservada. Entendem os adeptos dessa corrente que foi necessário modernizar a teoria clássica do contrato para que tudo permanecesse funcionando regularmente, não havendo, porém, alterações qualitativas no ordenamento como querem fazer crer alguns, tampouco tais alterações se afastam das premissas que moldaram o teoria geral do contrato por conta do Welfare State ${ }^{190}$. Como bem aponta TARTUCE, contudo, a evolução da doutrina e da jurisprudência brasileira já demonstra que essa não é a realidade ${ }^{191}$.

\subsubsection{Interpretação dos contratos no ordenamento brasileiro}

Segundo BETTI, o processo de interpretação é triádico, ou seja, composto por três elementos, sendo eles o objeto a ser interpretado, o autor do objeto e o intérprete. Tal processo difere da simples explicação, uma vez que nesta há apenas o objeto a ser explicado e quem o explica ${ }^{192}$.

\footnotetext{
${ }^{188}$ AZEVEDO, Antonio Junqueira de. O direito civil tende a desaparecer? Revista dos Tribunais, São Paulo, n. 472, p. 16-19, fev. 1975.

${ }^{189}$ Cf. TARTUCE, Flavio. Função social dos contratos: do Código de Defesa do Consumidor ao Código Civil de 2002, cit., p. 45.

${ }^{190}$ Cf. GRAU, Eros Roberto; FORGIONI, Paula Andréa. Ainda um novo paradigma dos contratos? In: . O Estado, a empresa e o contrato. São Paulo: Malheiros Ed., 2005. p. 23.

${ }^{19} \overline{\mathrm{Cf}}$. TARTUCE, Flavio. Função social dos contratos: do Código de Defesa do Consumidor ao Código Civil de 2002, cit., p. 284.

${ }^{192}$ Cf. BETTI, Emilio. Teoria generale della interpretazione. Milano: Giuffrè, 1955. p. 65-71, 205-224.
} 
Mencionado autor ainda destaca três espécies de interpretação, a saber: (i) aquela que procura apenas compreender o objeto da interpretação, sem acrescentar nada, tal qual ocorre na interpretação de fatos históricos e da filologia ${ }^{193}$; (ii) aquela que procura compreender para agir, com uma determinada finalidade, como se verifica com a religião, ou com um manual de instruções para utilização de um determinado equipamento, ou, ainda, com as próprias normas jurídicas; e (iii) finalmente, a interpretação para deleite, que é aquela observada, principalmente, no campo artístico ${ }^{194}$.

No tocante à metodologia de interpretação, BETTI construiu a doutrina dos "cânones hermenêuticos", a qual também se aplica à interpretação normativa, cuja finalidade era explicar as quatro etapas a serem observadas pelo intérprete na construção do processo interpretativo ${ }^{195}$.

O primeiro cânone, chamado de cânone da imanência, determina que o intérprete deve procurar o sentido que vem do próprio objeto, com humildade, sem contaminá-lo com conhecimentos prévios.

Já o segundo cânone - cânone da totalidade hermenêutica - impõe a necessidade de contextualização do objeto da interpretação, isto é, deve-se levar em conta todo o sistema no qual o objeto encontra-se inserido, bem como as circunstâncias históricas e culturais que vigiam quando da elaboração do objeto.

O terceiro cânone (da atualidade do entendimento), também conhecido por arco hermenêutico, exige que seja feita uma atualização do entendimento, trazendo o objeto a ser interpretado do momento passado para o momento presente.

Finalmente, o intérprete deve verificar quais as repercussões e consequiências que o resultado da interpretação acarretará nas pessoas, ao que se deu o nome de cânone finalista ou teleológico ou, ainda, cânone da consonância.

Em 1960, a doutrina dos "cânones hermenêuticos" foi criticada por GADAMER, sob dois fundamentos. O primeiro deles dizia que o pensamento humano é movido por um ir e vir constante e, nesse processo, a mente humana tende a corrigir a percepção dos fatos. Assim, não haveira um arco hermenêutico, como queria BETTI, mas um espiral hermenêutico, em linha com o que HASSAMER pregava no Direito Penal, ou seja, o

\footnotetext{
${ }^{193}$ A filologia tem por objeto a etimologia das palavras.

${ }^{194}$ Cf. BETTI, Emilio. op. cit., p. 343-389.

${ }^{195}$ Sobre os cânones hermenêuticos, vide: Id. Ibid., p. 292-342.
} 
intérprete deve fazer um movimento constante do fato para a lei, e da lei para o fato, subindo como um espiral até encontrar a solução.

O segundo fundamento criticava o primeiro cânone de BETTI (cânone da imanência), pois, segundo GADAMER, o intérprete é dotado de uma pré-compreensão sobre o objeto, de modo que seria impossível interpretá-lo sem se deixar influenciar por seus conhecimentos prévios.

Ambos os autores estão corretos. No momento da interpretação jurídica, deve-se tentar buscar o sentido que vem do próprio objeto, levando-se em conta todo o sistema no qual ele está inserido e o contexto atual, bem como as repercussões que o resultado da interpretação acarretará nas pessoas. Todavia, não se pode esquecer que o Direito é uma ciência humama e, muitas vezes, para se chegar ao resultado mais justo, é preciso que o aplicador do direito corrija a percepção dos fatos e faço uso de conhecimentos prévios que tenha a respeito de situações semelhantes.

Para tanto, foram criados mecanismos como as cláusulas gerais, que possibilitam ao aplicador do direito trazer elementos de outros sistemas, como o social, por exemplo, para dentro do caso concreto. Para evitar, porém, que tal processo seja muito subjetivo, o próprio sistema cria alguns balizadores, tal qual a necessidade de se observarem os princípios que regem a conduta das partes, não podendo o intérprete fazer uso de critérios pessoais de justiça.

A interpretação dos contratos, de um modo geral, portanto, está intimamente ligada aos princípios aplicáveis aos contratos, aceitos pelo ordenamento em questão. Daí porque a evolução da teoria contratual, acima analisada, influencia sobremaneira a interpretação contratual.

A elaboração do Código Civil de 2002 foi guiada por três princípios básicos: a eticidade, a sociabilidade e a operabilidade ${ }^{196}$. O primeiro deles busca conciliar os valores da técnica jurídica conquistados durante a vigência do Código Civil de 1916 com os valores éticos então vigentes quando da elaboração do novo código ${ }^{197}$. A introdução em nosso ordenamento dos princípios da boa-fé objetiva e da função social dos contratos, por exemplo, está em linha com a eticidade almejada pelo legislador.

\footnotetext{
${ }^{196}$ Cf. REALE, Miguel. O novo Código Civil. Disponível em: <www.miguelreale.com.br>. Acesso em: 16 jan. 2009.

${ }^{197}$ Cf. GAGLIANO, Pablo Stolze; PAMPLONA FILHO, Rodolfo. Novo curso de direito civil: parte geral. 7. ed. São Paulo: Saraiva, 2006. v. 1, p. 57.
} 
Como conseqüência prática de tal princípio, foram conferidos maiores poderes hermenêuticos ao magistrado, especialmente em razão do fato da normatização do atual código ter privilegiado as cláusulas gerais, que deverão ser preenchidas no caso concreto pelo aplicador do direito.

A técnica legislativa mais tradicional é a casuística, na qual o legislador descreve todos os elementos que compõem a hipótese legal e prescreve a respectiva conseqüência jurídica. Tal forma de legislar resulta num sistema fechado, dominado pela idéia de completude do ordenamento. Resta, nesse campo, pouco espaço de manobra, limitando-se o juiz, no mais das vezes, a uma atividade de subsunção do caso concreto à previsão da norma abstrata.

Já a técnica da chamada cláusula geral é distinta, marcada pela utilização de expressões vagas e de significado plúrimo. Aqui, o legislador não traça exaustivamente os contornos da hipótese legal, tampouco suas conseqüiências. Muito pelo contrário, são fornecidos somente critérios valorativos, com base nos quais o julgador fica livre para criar a norma jurídica particular mais adequada ao caso apreciado ${ }^{198}$.

Sob o escólio de JUDITH MARTINS COSTA, pode-se afirmar que, considerada do ponto de vista da técnica legislativa, a cláusula geral constitui uma disposição normativa que utiliza, no seu enunciado, uma linguagem de tessitura intencionalmente 'aberta', 'fluida' ou 'vaga', caracterizando-se pela ampla extensão do seu campo semântico, a qual é dirigida ao juiz de modo a lhe conferir um mandato (ou competência) para que, à vista dos casos concretos, crie, complemente ou desenvolva normas jurídicas ${ }^{199}$.

É claro que a atividade criadora do julgador, ao fazer uso da cláusula geral, encontra limites. Nesse sentido, deve ser feita mediante a utilização de princípios implícita ou explicitamente presentes dentro dos lindes do sistema jurídico, em dado momento histórico-político. Cabe ao juiz, enfim, buscar nos valores básicos que informam o ordenamento critérios para complementar o significado da norma geral e dar-lhe conteúdo específico para determinada situação prática.

\footnotetext{
${ }^{198}$ As cláusulas gerais podem ser conceituadas, nas palavras de TEPEDINO, como normas que não prescrevem uma certa conduta, mas, simplesmente, definem valores e parâmetros hermenêuticos. Servem, assim, como ponto de referência interpretativo e oferecem ao intérprete os critérios axiológicos e os limites para a aplicação das demais disposições normativas (Cf. TEPEDINO, Gustavo. Crise de fontes normativas e técnica legislativa na parte geral do Código Civil de 2002. In:___. A parte geral do novo Código Civil: estudos na perspectiva civil constitucional. Rio de Janeiro: Renovar, 2002. p. 19).

${ }^{199}$ Cf. MARTINS-COSTA, Judith. A boa-fé no direito privado. São Paulo: Ed. Revista dos Tribunais, 2000. p. 303.
} 
O princípio da sociabilidade, por sua vez, busca preservar o sentido de coletividade, em contraposição à ideologia individualista e patrimonialista do código civil revogado. Tal inversão de concepção buscou refletir as inúmeras modificações pelas quais passou a sociedade, tal qual o incremento dos meios de comunicação, o surgimento da sociedade de consumo de massa, a "standardização" dos negócios etc. ${ }^{200}$. Em razão desse princípio, foi conferida uma função social aos seis principais ícones do Direito Privado: a propriedade, a posse, o contrato, a empresa, a família e a morte ${ }^{201}$.

Por fim, o princípio da operabilidade tem por objetivo tornar mais claras as disposições do Código Civil, de forma a facilitar a interpretação e aplicação dos institutos nele previstos. Nele, estão implícitas as idéias de concretude - que também pode ser observada pela introdução das cláusulas gerais, que possibilita ao magistrado completar o direito posto com outros elementos, de forma a tornar o direito prático, fático e concreto e simplicidade - conforme se nota da divisão em parte geral e especial, bem como pela previsão taxativa e conceitual dos contratos em espécie ${ }^{202}$.

Tais princípios estão interligados com a Teoria Tridimensional de REALE ${ }^{203}$, a qual defende, ao contrário da teoria normativa kelseniana ${ }^{204}$, a presença e co-relação, em qualquer expressão da vida jurídica, de fato, valor e norma, seja ela estudada pelo filósofo ou sociólogo do direito, ou pelo jurista como tal. Desse modo, o jurista com formação baseada na concepção de um direito essencialmente normativo terá sérias dificuldades em aplicar o atual Código Civil, eis que este traz em seu bojo uma enorme carga valorativa e fática $^{205}$.

Ademais, não se pode olvidar que o direito civil, com o advento da Constituição Federal de 1988, passou a ter um novo parâmetro de interpretação, havendo uma interação simbiótica entre o direito constitucional e o direito civil, bem como uma inversão da forma

${ }^{200} \mathrm{Cf}$. TARTUCE, Flavio. Tendências do novo direito civil: uma codificação para o $3^{\circ}$ milênio. Compreendendo a nova codificação. Disponível em: <http://www.flaviotartuce.adv.br/secoes/artigos.asp>. Acesso em: 22 dez. 2008.

${ }^{201}$ Embora a função social de alguns desses institutos não esteja expressa no Código Civil de 2002, é possível inferir, pelo todo, que todos eles devem observar uma função social. Para maior profundamento, vide: TARTUCE, Flavio. Função social dos contratos: do Código de Defesa do Consumidor ao Código Civil de 2002, cit., p. 59-65.

${ }^{202}$ Cf. Id. Ibid., p. 65-67.

${ }^{203} \mathrm{~A}$ esse respeito, vide: REALE, Miguel. Teoria tridimensional do direito: situação atual. São Paulo: Saraiva, 2003.

${ }^{204}$ Tal teoria foi amplamente tratada por HANS KELSEN no livro intitulado Teoria pura do direito. Trad. por João Baptista Machado. 6. ed. São Paulo: Martins Fontes, 2000.

${ }^{205}$ Cf. TARTUCE, Flavio. Função social dos contratos: do Código de Defesa do Consumidor ao Código Civil de 2002, cit. e Id. Tendências do novo direito civil: uma codificação para o $3^{\circ}$ milênio. Compreendendo a nova codificação, cit. 
de interação dos dois ramos do Direito - o Público e o Privado - isto é, o Código Civil, atualmente, deve ser interpretado segundo a Constituição Federal, e não o contrário $^{206}$. A tal fenômeno se deu o nome de "Direito Civil Constitucional", o qual:

"nada mais é do que a harmonização entre os pontos de intersecção do Direito Público e o Direito Privado, mediante a adequação de institutos que SÃO, em sua essência, elementos de Direito Privado mas que ESTÃO na Constituição"207.

O Código Civil de 2002 não trouxe um capítulo sobre interpretação dos contratos, apresentando apenas algumas normas específicas sobre interpretação. A principal delas, para o presente estudo, está consubstanciada no art. 113, o qual prescreve que: "os negócios jurídicos devem ser interpretados conforme a boa-fé e os usos do lugar de sua interpretação".

Também os arts. 112 e 423 merecem ser lembrados ${ }^{208}$, uma vez que o primeiro deles determina que a intenção das partes, no momento das declarações de vontade, deverá ser sempre levada em conta, e não somente o sentido literal da linguagem, enquanto o segundo tem por objetivo proteger o aderente, exigindo que, em caso de cláusulas ambíguas ou contraditórias, seja adotada a interpretação mais favorável ao aderente ${ }^{209}$.

A introdução de novos princípios no atual Código Civil alterou, profundamente, o modo de interpretação dos contratos. Durante muito tempo, a teoria contratual se ergueu basicamente em cima dos três princípios clássicos anteriormente analisados, a saber: a força obrigatória dos contratos, a relatividade dos efeitos contratuais e a autonomia da vontade.

\footnotetext{
${ }^{206}$ TARTUCE aponta que, "com o advento da Constituição de 1988, novas diretrizes foram impostas à vida social de nosso país, além de estabelecer novo parâmetro para interpretação e aplicação do Direito positivo pátrio. A Constituição brasileira, como norma máxima no âmbito de um Estado, e fruto de forte tendência à "socialização" do Direito que atinge os mais modernos ordenamentos ocidentais, criou novas regras e fixou novos paradigmas não só com relação à organização do Estado, mas também sobre outras áreas do Direito" (TARTUCE, Flavio. Direito civil e Constituição. Disponível em: $<\mathrm{http}$ ://www.flaviotartuce.adv.br/secoes/artigos.asp>. Acesso em: 22 dez. 2008).

${ }^{207}$ Cf. Id. Ibid.

${ }^{208}$ Também são regras de interpretação dos negócios jurídicos no Código Civil aquelas consubstanciadas nos arts. 114 e 819 , a saber:

"Art. 114. Os negócios jurídicos benéficos e a renúncia interpretam-se estritamente".

"Art. 819. A fiança dar-se-á por escrito, e não admite interpretação extensiva".

${ }^{209}$ Art. 47 do microssistema jurídico formado pelo CDC vai ainda mais além, determinando que "as cláusulas contratuais serão interpretadas de maneira mais favorável ao consumidor", ainda que o contrato tenha sido negociado.
} 
Desde que se percebeu que a noção de autonomia negocial ilimitada, típica do liberalismo clássico, conduzia a injustiças graves, passou-se a exigir interferência estatal direta para a correção de desequilíbrios nas relações jurídicas, modificando-se os paradigmas do direito contratual.

Essa percepção, que historicamente se deu no seio da passagem do Estado Liberal para o Welfare State, marcou o início da compreensão de uma nova dimensão do contrato, marcadamente ética e solidarista. O contrato, então, deixou de ser apenas o reflexo dos interesses das partes, sobressaindo-se os valores da igualdade real, equilíbrio e cooperação entre elas.

No direito brasileiro, foi a própria Constituição Federal que passou a exigir a proteção desses "novos" valores. Isso porque a Lei Maior estatui expressamente, como objetivo fundamental da República, a construção de uma sociedade livre, justa e solidária $^{210}$. Daí, podem ser extraídos os novos princípios sociais, os quais, embora antes já estivessem de certa forma presentes no ordenamento pátrio, foram introduzidos pelo Código Civil.

Tais novos princípios, dentre os quais se atribui especial relevância para o equilíbrio econômico-financeiro do contrato, a função social dos contratos e a boa-fé objetiva (que existe desde os primórdios, mas voltou a ter peso na interpretação contratual recentemente), somaram-se aos já existentes ${ }^{211}$.

O princípio da força obrigatória do contrato (pacta sunt servanda) ainda deve ser levado em conta no momento da interpretação do contrato, com vistas a assegurar um mínimo de certeza e segurança que se espera do ordenamento jurídico, mas encontra-se, atualmente, mitigado pelos novos princípios sociais ${ }^{212}$.

\footnotetext{
210“Art. 3". Constituem objetivos fundamentais da República Federativa do Brasil: I - construir uma sociedade livre, justa e solidária; (...)".

${ }^{211}$ Embora a introdução dos princípios sociais de modo expresso em nosso ordenamento tenha de certa forma representado uma mudança de paradigmas e o abandono das premissas até então vigentes, os princípios clássicos não deixaram de existir, tampouco de ter relevância para as relações jurídicas atuais, mas apenas passaram a conviver com novos princípios.

${ }^{212}$ Deve-se encontrar um meio termo entre a força obrigatório dos contratos e os novos princípios sociais. DANIEL SICA DA CUNHA pondera que "negar a força obrigatória do contrato é proclamar sua morte, ao passo que negar a nova realidade contratual, permanecendo apegado tão-somente aos princípios clássicos em uma era sufocada pela massificação social, é fechar os olhos para uma realidade que se impõe" (CUNHA, Daniel Sica da. A nova força obrigatória dos contratos. In: MARQUES, Claudia Lima (Coord). A nova crise do contrato: estudos sobre a nova teoria contratual. São Paulo: Ed. Revista dos Tribunais, 2007. p. 252).
} 
A obrigatoriedade do contrato, hoje, decorre muito mais de uma noção de justiça e utilidade social do que da vontade dos contraentes. O contrato somente deverá prevalecer se for justo e útil, sendo que a noção de justiça não é mais considerada uma consequência do que as partes haviam originalmente pactuado $^{213}$.

Do mesmo modo, também o princípio da relatividade dos efeitos contratuais ainda é um dos pilares da interpretação contratual, mas comporta, atualmente, algumas exceções. Em primeiro lugar, pode-se citar a estipulação em favor de terceiros, prevista nos arts. 436 a 438 do Código Civil, pois, nesta hipótese, o contrato gera efeitos e atinge um terceiro que não é parte do contrato (efeitos exógenos do contrato). Como exemplo, há o contrato de seguro com um terceiro beneficiário ${ }^{214}$.

Também a promessa de fato de terceiro, regulada pelos arts. 439 a 440 do Código Civil, pode ser considerada uma exceção ao princípio da relatividade dos efeitos contratuais, já que, nesta situação, a conduta de um terceiro que não é parte no contrato causa repercussão para as partes contratantes (efeitos endógenos do contrato). É o caso, por exemplo, de um promotor de eventos que promete a um empresário um show de um cantor famoso, que não comparece. Ainda que o não comparecimento não tenha sido causado por ato do promotor de eventos, este responderá civilmente perante o empresário.

Outra exceção à relatividade dos efeitos contratuais é o consumidor equiparado (ou bystander), com base no artigo 17 e parágrafo único do artigo $2^{\circ}$ do $\mathrm{CDC}$, pois, mesmo não integrando a relação direta de consumo, este poderá se valer dos benefícios do CDC.

Finalmente, vale mencionar o Enunciado 21 do Conselho da Justiça Federal, o qual reza que a função social do contrato impõe a revisão do princípio da relatividade dos efeitos contratuais, possibilitando a tutela externa do crédito, isto é, um terceiro não pode conscientemente desrespeitar a existência do contrato, em prejuízo de uma das partes, o que está em linha também com o princípio da função social dos contratos ${ }^{215}$. O famoso caso do cantor Zeca Pagodinho pode ser citado como exemplo, pois a Brahma desrespeitou o contrato de tal cantor com a Schincariol, que era de conhecimento público e notório, para

\footnotetext{
${ }^{213}$ A esse respeito, vide: GUESTIN, Jacques. Le juste et l'utile dans les effets du contrat. In: MONTEIRO, António J. M. Pinto (Coord.). Contratos: actualidade e evolução. Porto: Coimbra Ed., 1997. p. 123-165.

${ }^{214}$ Cf. TARTUCE, Flavio. Função social dos contratos: do Código de Defesa do Consumidor ao Código Civil de 2002, cit., p. 190-191.

${ }^{215} \mathrm{O}$ art. 608 do Código Civil prescreve que aquele que aliciar pessoas obrigadas por um contrato escrito a prestar serviços a outrem pagará a este o correspondente a dois anos de prestação de serviço. A responsabilidade referenciada em tal artigo é apenas a material, já que a indenização por danos morais não pode ser tarifada.
} 
realizar uma campanha publicitária com o mesmo cantor e que criticava de forma explícita a marca Nova Schin da empresa concorrente ${ }^{216}$.

A função social dos contratos, no entanto, não exclui a relatividade dos efeitos contratuais. Deve-se fazer a distinção entre oponibilidade do contrato perante terceiros obrigação de não fazer imposta pelo princípio da função social do contrato (obrigação daquele que conhece o conteúdo do contrato de respeitar as situações jurídicas por ele criadas) - da exigibilidade de obrigações contratuais em face de terceiros estranhos ao contrato, que é exatamente o que o princípio da relatividade dos efeitos contratuais impede, com exceções, como visto acima ${ }^{217}$.

Já o princípio da autonomia da vontade, tão importante no século XIX, como visto, foi "substituído" pela autonomia privada ${ }^{218}$. Esta pode ser considerada o direito que a pessoa tem de regulamentar os próprios interesses, direito esse decorrente da dignidade da pessoa humana ${ }^{219}$. Segundo os ensinamentos de BETTI, a autonomia privada é considerada a atividade destinada a criar, modificar ou extinguir relações jurídicas entre indivíduos ${ }^{220}$.

Tal "substituição" se deu em razão de a vontade ter perdido o papel tão relevante que outrora exercia, tendo surgido outros elementos na formação do contrato, tais como a imposição de cláusulas contratuais pelo Estado e pela lei (dirigismo contratual) e a imposição de cláusulas pela parte mais forte da relação jurídica. Sem contar que, nos tempos modernos, predominam os contratos de adesão e os contratos standards, em que a vontade de um dos contratantes é mitigada ${ }^{221}$. Hoje, fala-se inclusive que a autonomia

\footnotetext{
${ }^{216}$ Há mais de uma ação que trata do caso Zeca Pagodinho e a guerra das cervejarias, mas é possível ter uma boa noção dos argumentos que permearam o caso a partir da Apelação 7.155.293-9, TJSP, $14^{a}$ Cam. Direito Privado, Rel. Des. Pedro Ablas, j. 09.04.2008.

${ }^{217}$ Cf. NEGREIROS, Teresa. op. cit., p. 272-273.

${ }^{218}$ MARIA ARACY diferencia a autonomia da vontade da autonomia privada, dizendo que a primeira refere-se ao livre agir do sujeito, ligada, portanto, à vontade interna, psíquica, manifestação de vontade livre, ao passo que a segunda é o poder de criar normas para si (Cf. COSTA, Maria Aracy Menezes da. op. cit., p. 230). A expressão "autonomia privada", portanto, é de certa forma mais genérica, uma vez que não está ligada ao voluntarismo e individualismo jurídico, como bem acentuou TERESA NEGREIROS (Cf. NEGREIROS, Teresa. op. cit., p. 4).

${ }^{219}$ DANIEL SARMENTO aponta que "(...) a dignidade da pessoa humana é o princípio mais relevante da nossa ordem jurídica, que lhe confere unidade de sentido e de valor, devendo por isso condicionar a inspirar a exegese e aplicação de todo o direito vigente, público ou privado" (SARMENTO, Daniel. Direitos fundamentais e relações privadas. 2. ed. Rio de Janeiro: Lumen Juris, 2006. p. 86). Com relação à definição de autonomia privada, vide: SARMENTO, Daniel. op. cit., p. 154.

${ }^{220}$ BETTI, Emilio. Teoria general del negocio jurídico. Trad. Espanhola. Madrid: Ed. Revista de Derecho Privado, 1995. p. 40.

${ }^{221} \mathrm{~F}$. TARTUCE aponta que "antes a autonomia da vontade ditava as regras do pacto, fazendo com que seus dispositivos tivessem força legislativa inter partes. Agora, entretanto, não mais temos a autonomia da vontade como fator essencial dos contratos; predominam os contratos por adesão, os acordos de massa; não há mais a discussão das cláusulas contratuais; estamos sob a égide do que aqui denominamos "Império dos Contratos Modelo" (TARTUCE, Flavio. Direito civil e Constituição, cit.). Vale apontar,
} 
privada muitas vezes deixa de ser considerada a capacidade de gerir os próprios interesses para uma situação de ser gerido, especialmente nos contratos existenciais ${ }^{222}$, incluindo-se aí não somente aqueles de consumo, mas também os contratos de locação, contratos de trabalho, e contratos de adesão interempresariais ${ }^{223}$. Finalmente, vale apontar que o próprio termo "autonomia privada" é mais coerente, uma vez que a autonomia não é da vontade, mas da pessoa, em linha com a tendência de personalização do Direito Privado ${ }^{224}$.

A evolução da Teoria Contratual introduziu, além dos princípios acima mencionados, novos princípios, muito mais relacionados aos aspectos sociais dos contratos do que os princípios clássicos acima mencionados. Tais princípios são primordiais para a interpretação dos negócios jurídicos, nos tempos atuais.

Primeiramente, cabe mencionar que foi introduzida no seio da teoria contratual a noção de equilíbrio econômico no contrato, que traz a preocupação com o justo como critério paritário de distribuição dos bens. As prestações de um e de outro contraente devem guardar entre si um nível razoável de proporcionalidade. Se restar comprovada a exagerada ou excessiva discrepância entre as obrigações assumidas por cada contratante, estará configurada a inexistência de paridade entre ambos e, portanto, a injustiça do instrumento contratual firmado ${ }^{225}$.

A justiça contratual no direito clássico estava vinculada somente ao processo de formação do contrato e à manifestação da vontade contratual, não levando em conta o efetivo conteúdo das cláusulas contratuais. O princípio do equilíbrio econômico-financeiro do contrato teve por objetivo exatamente alterar a noção de justiça contratual.

Tal princípio já havia sido consagrado no CDC, mas foi também introduzido no Código Civil de 2002. O CDC explicita referido princípio mais especificamente nos seguintes dispositivos: (i) art. $4^{\circ}$, III, que trata da harmonização dos interesses dos participantes das relações de consumo, com base também no equilíbrio econômico; (ii) art.

entretanto, que o uso dos contratos de adesão e dos contratos standards não é, em princípio, prejudicial ao sistema. Pelo contrário, tais contratos reduzem os custos de transação, na medida em que as partes somente perdem tempo negociando os pontos essenciais do contrato, tais como preço e quantidade. Ocorre que esse tipo de contrato é geralmente utilizado justamente no seio do mercado de consumo, sendo que a grande parte dos consumidores não lê, tampouco compreende o conteúdo dos contratos a que estão aderindo (Cf. WIJCK, Peter van; THEEUWES, Jules. Protection against unfair contracts: an economic analysis of european regulation. European Journal of Law and Economics, v. 9, p. 73-89, p. 77, 2000).

${ }^{222} \mathrm{~A}$ dicotomia entre contratos existenciais e contratos de lucro será explanada mais adiante.

${ }^{223}$ Cf. PENTEADO, Luciano de Camargo. Prefácio à $2^{\text {a }}$ edição. In: TARTUCE, Flavio. Função social dos contratos: do Código de Defesa do Consumidor ao Código Civil de 2002. p. 16-17.

${ }^{224}$ Cf. TARTUCE, Flavio. Função social dos contratos: do Código de Defesa do Consumidor ao Código Civil de 2002, cit., p. 177.

${ }^{225}$ Cf. NEGREIROS, Teresa. op. cit., p. 168-169. 
$6^{\circ}, \mathrm{V}$, que confere ao consumidor o direito básico de modificar as cláusulas contratuais que estabeleçam prestações desproporcionais; (iii) art. 39, V, que considera prática abusiva exigir do consumidor vantagem manifestamente excessiva; e, finalmente, (iv) art. 51, IV, que declara nula de pleno direito a cláusula contratual que estabeleça "obrigações iníquas, abusivas, que coloquem o consumidor em desvantagem exagerada"226.

O Código Civil, por sua vez, introduziu o princípio do equilíbrio econômicofinanceiro do contrato no art. 157, que trata da lesão, e nos arts. 317 e 478 a 480, que cuidam da onerosidade excessiva.

A função social dos contratos, princípio geral de direito de ordem pública, por sua vez, impõe que o contrato deva ser necessariamente interpretado e visualizado de acordo com o contexto da sociedade. Tal princípio está relacionado com a proteção dos direitos inerentes à dignidade da pessoa humana, amparada no art. $5^{\circ}$ da Constituição Federal de $1988^{227}$.

O art. 421 do Código Civil introduziu expressamente a função social dos contratos em nosso ordenamento, ao estabelecer que "a liberdade de contratar será exercida em razão e nos limites da função social do contrato".

Referido artigo, contudo, traz algumas imprecisões ${ }^{228}$. Em primeiro lugar, fala em "liberdade de contratar", que é relacionada com a celebração do contrato e, em regra, é ilimitada, ao invés de mencionar a "liberdade contratual", que diz respeito ao conteúdo do negócio, esta sim limitada pela função social. Em segundo, menciona a função social como razão do contrato, quando na verdade a razão do contrato é a autonomia privada, figurando a função social como limite do contrato ${ }^{229}$. Assim, o magistrado, quando da aplicação deste artigo, deverá levar em conta tais correções, com vistas a interpretar corretamente o contrato, em linha com sua função social.

\footnotetext{
${ }^{226}$ Cf. CARDOSO, Débora Rezende. O fim negativo do contrato no Código Civil de 2002: resolução por onerosidade excessiva. In: MARQUES, Claudia Lima (Coord). A nova crise do contrato: estudos sobre a nova teoria contratual. São Paulo: Ed. Revista dos Tribunais, 2007. p. 544.

${ }^{227}$ Segundo TARTUCE, “a nova concepção de contrato (...) é uma concepção social, onde não só o momento da manifestação da vontade, mas também a condição social e econômica das pessoas nele envolvidas, além dos efeitos do contrato na realidade social é que serão levados em conta para a validade, eficácia e perpetuação da avença" (TARTUCE, Flavio. Direito civil e Constituição, cit.).

${ }^{228}$ A respeito das imprecisões do art. 421 do Código Civil, vide Id. Função social dos contratos: do Código de Defesa do Consumidor ao Código Civil de 2002, cit., p. 241-243.

${ }^{229}$ Esta última crítica foi elucidada pelo Enunciado 23 do Conselho da Justiça Federal, o qual estabelece que a função social do contrato não elimina o princípio da autonomia contratual, mas atenua ou reduz o alcance desse princípio, quando presentes interesses meta-individuais ou interesses individuais relacionados com a dignidade humana. Segundo esse enunciado, portanto, o princípio da força obrigatória do contrato não está eliminado, mas apenas relativizado.
} 
O aplicador do direito, ainda, no momento da interpretação contratual, deverá considerar os efeitos inter-partes e extra-partes da função social dos contratos ${ }^{230}$. Como efeitos inter-partes, podemos citar a mitigação da força obrigatória do contrato, a proteção da parte vulnerável na relação contratual, a vedação da onerosidade excessiva, a tendência de conservação do contrato, dentre outros. Inúmeros são os dispositivos do Código Civil que refletem a eficácia interna da função social dos contratos, tal como o art. 413, que prevê a redução por eqüidade da cláusula penal ou multa como um dever do magistrado quando a obrigação tiver sido cumprida em parte ou quando a multa gerar onerosidade excessiva; os arts. 423 e 424 desse mesmo código, que introduzem o princípio da equivalência material, visando proteger o aderente no contrato de adesão; dentre outros. Além disso, ainda é possível mencionar o Enunciado 22 do Conselho da Justiça Federal, que determina que a função social deve reforçar o princípio da conservação dos contratos $^{231}$.

Por outro lado, é possível que um contrato seja bom para ambas as partes, totalmente equilibrado, mas, ainda assim, seja ruim para a sociedade, não devendo prevalecer, portanto, também pela aplicação da função social dos contratos. Trata-se dos efeitos extra-partes que esse princípio apresenta. Um bom exemplo é o caso de um contrato celebrado entre uma empresa e uma agência de publicidade, pelo qual a esta última caberia veicular uma propaganda discriminatória. A publicidade poderia vir a ser retirada do ar e o contrato deixaria de produzir efeitos, com vistas a resguardar os interesses da sociedade ${ }^{232}$. Fala-se, ainda, em função socioambiental do contrato, o qual não pode gerar danos ao meio ambiente, ainda que do ponto de vista inter-partes não haja qualquer prejuízo ${ }^{233}$.

O principal dispositivo que trata da função social dos contratos, contudo, não é o art. 421 do Código Civil, como à primeira vista poderia parecer, mas sim o art. 2.035, parágrafo único, desse mesmo diploma legal, na medida em que ao assimilar a função dos

\footnotetext{
${ }^{230}$ Sobre a eficácia interna e externa da função social dos contratos, TARTUCE resume bem na conclusão de sua obra Função social dos contratos: do Código de Defesa do Consumidor ao Código Civil de 2002, cit., p. 415-416.

${ }^{231}$ Tal enunciado apresenta a função social dos contratos como uma cláusula geral que reforça o princípio da conservação do contrato, assegurando trocas úteis e justas. Como a conservação contratual é preceito de ordem pública, a extinção, nulidade ou anulabilidade de um contrato deve ser sempre o último caminho a ser percorrido, devendo-se buscar, antes, sua revisão.

${ }^{232} \mathrm{Cf}$. TARTUCE, Flavio. A função social dos contratos, a boa-fé objetiva e as recentes súmulas do Superior Tribunal de Justiça, cit.

${ }^{233} \mathrm{Cf}$. Id. Sentença: a boa-fé objetiva e o dever do credor de mitigar a perda (duty to mitigate the loss). In: HIRONAKA, Giselda Maria Fernandes Novaes (Coord.). A outra face do Poder Judiciário: decisões inovadoras e mudanças de paradigmas. Belo Horizonte: Del Rey, 2007. v. 2, p. 50.
} 
contratos à da propriedade, ressalta a dimensão constitucional do instituto e insere a matéria como de ordem pública ${ }^{234}$.

Finalmente, o princípio da boa-fé, que anteriormente estava relacionado apenas ao plano intencional das partes (boa-fé subjetiva), evoluiu, passando a impor alguns deveres anexos ou laterais, inerentes a qualquer negócio, ainda que não haja previsão expressa no instrumento contratual (boa-fé objetiva), tais como o dever de cuidado, o dever de respeito, o dever de colaboração ou cooperação, o dever de lealdade, o dever de agir conforme a eqüidade e a razoabilidade, e o dever de confiança ${ }^{235}$.

A boa-fé objetiva é entendida como uma regra de conduta ${ }^{236}$, segundo a qual justamente para fins de promoção da justiça e solidarismo - espera-se dos indivíduos que tenham suas condutas pautadas pela lealdade e correção, segundo aquilo que se esperaria do homem médio ${ }^{237}$.

De fato, como ensina JUdiTH MARTINS COSTA, ao conceito de boa-fé objetiva estão subjacentes os ideais que animaram a boa-fé germânica: a boa-fé como regra de conduta fundada na honestidade, na retidão, na lealdade e, principalmente, " $n a$ consideração para com os interesses do 'alter', visto como um membro do conjunto social que é juridicamente tutelado"238. Aí se insere a consideração para com as expectativas legitimamente geradas, pela própria conduta, nos demais membros da comunidade, especialmente no outro pólo da relação obrigacional ${ }^{239}$.

Assim também preconiza o magistério de LAERTE SAMPAIO ao afirmar que a boa-fé objetiva é um princípio, sinalizando às partes um tipo de conduta a ser seguida. Segundo o autor, este princípio impõe ao contratante o dever de agir de acordo com determinados padrões, socialmente recomendados, de correção, lisura, honestidade, não frustrando a

\footnotetext{
${ }^{234}$ Cf. LUCIANO DE CAMARGO PENTEADO no prefácio à $2^{\mathrm{a}}$ edição do livro TARTUCE, Flavio. Função social dos contratos: do Código de Defesa do Consumidor ao Código Civil de 2002, cit., p.19. Para TARTUCE, ainda, o artigo 2.035, parágrafo único, do Código Civil traz o princípio da retroatividade motivada ou justificada, pelo qual seria plenamente possível anular ou rever, judicialmente, negócio jurídico celebrado antes da vigência do Código Civil, desde que o negócio esteja gerando efeitos na vigência da atual codificação, com base no princípio da função social dos contratos (Cf. Id. Ibid., p. 398-411).

${ }^{235}$ Conforme estabelece o Enunciado 24 do Conselho da Justiça Federal, a quebra desses deveres anexos gera a violação positiva do contrato, modalidade de inadimplemento que independe de culpa (responsabilidade objetiva). Sobre o tema "violação positiva do contrato", vide: CORDEIRO, António Manuel da Rocha e Menezes. Da boa-fé no direito civil. Coimbra: Almedina, 2001. v. 1, p. 594-602.

${ }^{236}$ Difere, assim, da noção de boa-fé subjetiva, que é a consciência ou ignorância de determinada situação por parte do figurante do negócio.

${ }^{237}$ A boa-fé objetiva como regra de conduta foi amplamente estudada por CORDEIRO, António Manuel da Rocha e Menezes. op. cit., v. 1, p. 632-660.

${ }^{238}$ MARTINS-COSTA, Judith. op. cit., p. 412.

${ }^{239} \mathrm{Cf}$. Id., loc. cit.
} 
confiança legítima da outra parte. Nesse sentido, a boa-fé objetiva representa uma reação contra o individualismo ${ }^{240}$, cobrando das partes um comportamento que leve em conta o interesse do parceiro contratual, um agir solidário ${ }^{241}$.

BUENO DE GODOY entende que boa-fé objetiva e justiça contratual estão relacionadas de tal arte que o comportamento solidário torna-se o pressuposto necessário para uma contratação justa, que, de seu turno, não se compadece com a previsão de resultado desigual por conta da disparidade substancial das partes ${ }^{242}$.

Assim, sempre que o contrato apresentar desequilíbrio acentuado, excessivo e injusto, decorrente da posição de superioridade material de que eventualmente desfrute uma parte em relação à outra, ficará sujeito a controle judicial em virtude das exigências da boa-fé objetiva.

Vale lembrar que o princípio em comento já estava previsto no art. $4^{\circ}$, III, do CDC e o Enunciado 27 do Conselho da Justiça Federal determina que, na interpretação da cláusula da boa-fé, deve-se levar em conta o sistema do Código Civil e as conexões sistemáticas com outros estatutos normativos e fatores metajurídicos.

No Código Civil, a boa-fé objetiva apresenta três funções: (i) a função de interpretação, prevista no art. 113; (ii) a função de integração do contrato, estabelecida no art. 422, impondo que tal princípio deva estar previsto nas fases pré-contratual, contratual e pós-contratual, conforme determinam os Enunciados 25 (dirigido ao juiz) ${ }^{243}$ e 170 (dirigido às partes) $)^{244}$ do Conselho da Justiça Federal, e (iii) a função de controle, nos termos do art.

\footnotetext{
${ }^{240}$ Até mesmo no direito norte-americano, onde o individualismo é ainda dominante, existem algumas limitações aos interesses individuais no comportamento contratual. Um dos exemplos dessas limitações é exatamente o tratamento especial (com regras especiais) que recebem algumas relações onde a vulnerabilidade de uma das partes é particularmente acentuada, como é o caso do franchising. Essa vulnerabilidade é criada pelo contrato de franchising especialmente em razão da falta de sofisticação por parte dos franqueados e dos pesados investimentos que estes são obrigados a realizar no momento da celebração do contrato. Em decorrência disso, por exemplo, o contrato de franquia não pode ser denunciado pelo franqueador sem algumas proteções especiais, que lhe assegurem razoável retorno desses investimentos (Cf. NARASIMHAN, Subha. Individualism in american contract law: an i my brother's keeper. In: MONTEIRO, António J. M. Pinto (Coord.). Contratos: actualidade e evolução. Porto: Coimbra Ed., 1997. p. 235-239).

${ }^{241}$ Cf. SAMPAIO, Laerte Marrone de Castro. A boa-fé objetiva na relação contratual. São Paulo: Manole, 2004. p. 27.

${ }^{242}$ Cf. GODOY, Cláudio Luiz Bueno de. Função social do contrato. São Paulo: Saraiva, 2004. p. 49.

${ }^{243}$ Enunciado 25 do Conselho da Justiça Federal: o art. 422 do Código Civil não inviabiliza a aplicação pelo julgador do princípio da boa-fé nas fases pré-contratual e pós-contratual.

${ }^{244}$ Enunciado 170 do Conselho da Justiça Federal: a boa-fé objetiva deve ser observada pelas partes na fase de negociações preliminares e após a execução do contrato, quando tal exigência decorrer da natureza do contrato.
} 
187, já que comete abuso de direito aquele que desrespeita a boa-fé objetiva, ficando sujeito à responsabilização objetiva ${ }^{245}$.

Com relação à função interpretativa, a boa-fé objetiva exige, em linhas muito gerais, que se investigue não mais apenas a vontade individual de cada um dos contratantes, mas as intenções que emanam do consenso de ambos. Toma-se por base o sentido objetivo do contrato, a vontade contratual, como forma de se tutelar a confiança e a justa expectativa em relação à avença.

À função supletiva ou integrativa corresponde a compreensão de que, no âmbito da relação obrigacional, os deveres das partes não se resumem unicamente àqueles expressos no contrato. A boa-fé objetiva cria o que se vem chamando de deveres anexos, que são, genericamente, aqueles que não interessam diretamente ao cumprimento da prestação principal, mas objetivam garantir o bom desempenho da relação obrigacional como um todo. São os deveres gerais de proteção, cuidado, informação etc ${ }^{246}$.

Para o presente estudo, interessa mais de perto a função corretiva. É que ela se presta, justamente, ao controle do equilíbrio contratual.

Com efeito, é curial que a noção de boa-fé objetiva não pode compactuar com abusos, imposições e excessos que a desigualdade substancial permite sejam impingidos de uma parte à outra dentro de determinada relação obrigacional.

Nesse sentido, ClÁUdia Lima MARQUeS acrescenta que, ao se visualizar, sob influência do princípio da boa-fé objetiva, a obrigação como uma totalidade de deveres e direitos no tempo e ao definir também como abuso a unilateralidade excessiva ou o desequilíbrio irrazoável da engenharia contratual, valoriza-se, por consequiência, o equilíbrio intrínseco da relação em sua totalidade e redefine-se a razoabilidade em matéria de concessões do contratante mais fraco. Para a autora, boa-fé objetiva significa, portanto, uma atuação 'refletida', uma atuação pensando no outro, no parceiro contratual, respeitando-o, respeitando seus interesses legítimos, suas expectativas razoáveis, seus direitos, agindo com lealdade, sem abuso, sem obstrução, sem causar lesão ou

\footnotetext{
${ }^{245}$ Enunciado 37 do Conselho da Justiça Federal: a responsabilidade civil decorrente do abuso do direito independe de culpa e fundamenta-se somente no critério objetivo-finalístico.

${ }^{246}$ A respeito do alargamento e do papel dos deveres acessórios, vide: CORDEIRO, António Manuel da Rocha e Menezes. op. cit., v. 1, p. 603-631.
} 
desvantagem excessiva, cooperando para atingir o bom fim das obrigações, isto é, o cumprimento do escopo contratual e a realização dos interesses das partes ${ }^{247}$.

Assim como a função social dos contratos, também a boa-fé objetiva apresenta efeitos internos e externos em relação ao negócio jurídico patrimonial. Como efeitos internos, pode-se citar a própria exigência de conduta proba contida no art. 422 do Código Civil. Já os efeitos externos podem ser sentidos, por exemplo, nos casos em que um negócio jurídico a princípio nulo acaba por prevalecer diante da boa-fé objetiva e da boa conduta dos contratantes, ou quando o magistrado privilegia o terceiro de boa-fé em detrimento de um negócio jurídico validamente celebrado ${ }^{248}$.

Segundo o Enunciado 26 do Conselho da Justiça Federal, ainda, a cláusula geral contida no art. 422 do Código Civil impõe ao juiz o dever de interpretar e, quando necessário, suprir e corrigir o contrato tendo em vista a boa-fé objetiva, entendida como exigência de conduta leal dos contratantes.

Para corrigir o contrato em linha com os preceitos da boa-fé objetiva, MENEZES CORDEIRO aponta cinco principais conceitos, a saber: (i) suppressio; (ii) surrectio; (iii) tu quoque; (iv) exceptio doli; e (v) venire contra factum proprium non potest.

A suppressio pode ser entendida como a perda de um direito pelo seu não exercício no tempo, não se confundindo com a prescrição ou a decadência, por não haver prazo préestabelecido em lei. Além do decurso do tempo, GRIEBBELING ressalta que a caracterização da suppressio ainda requer: (i) um comportamento exterior, pelo qual o titular atue como se não tivesse o direito ou como se não pretendesse exercê-lo; (ii) a criação de confiança da contraparte de que o titular não exercerá o direito; e (iii) a geração de uma desvantagem injusta em razão do exercício superveniente do direito pela parte que havia dado a entender que não o exerceria ${ }^{249}$. Tal conceito guarda estreita semelhança com o venire contra factum proprium, na medida em que também serve para vedar comportamentos contraditórios, conforme será visto a seguir, mas na suppressio o fator "tempo" assume maior relevo ${ }^{250}$.

A surrectio, por seu turno, é o outro lado da moeda da suppressio, sendo caracterizada como o surgimento de um direito diante de práticas, usos e costumes. Aqui,

\footnotetext{
${ }^{247}$ Cf. MARQUES, Cláudia Lima. Contratos no Código de Defesa do Consumidor, cit,. 2002, p. 181.

${ }^{248} \mathrm{Cf}$. TARTUCE, Flavio. Sentença: a boa-fé objetiva e o dever do credor de mitigar a perda (duty to mitigate the loss), cit., v. 2, p. 49.

${ }^{249}$ Cf. CORDEIRO, António Manuel da Rocha e Menezes. op. cit., v. 2, p. 811, nota 607.

${ }^{250}$ Cf. Id. Ibid., v. 2, p. 812-813. No mesmo sentido, ZANETTI, Cristiano de Sousa. Responsabilidade pela ruptura das negociações. São Paulo: Juarez de Oliveira, 2005. p. 130.
} 
também leva-se em conta a previsão de confiança do sujeito por força do comportamento adotado pela contraparte. $\mathrm{O}$ art. 330 do Código Civil está em linha com tais preceitos, ao determinar que "o pagamento reiteradamente feito em outro local faz presumir renúncia do credor relativamente ao previsto no contrato". Há, nesta hipótese, a perda do direito do credor em receber o pagamento no local originariamente pactuado, com a consequente aquisição do direito do devedor de continuar pagando onde usualmente vinha fazendo ${ }^{251}$.

O conceito de tu quoque traz a idéia de que não se deve fazer com o outro o que não se faria contra si mesmo ${ }^{252}$. Está implícita a noção de diferença de critérios adotados pelo titular do direito para julgar e para julgar-se. No campo contratual, como aponta MENEZES CORDEIRO, o tu quoque guarda relação direta com a noção de sinalagma, ampliando os efeitos da exceção de contrato não cumprido, ao impedir que aquele que ponha em risco o cronograma contratual possa exigir que o outro o cumpra, ainda que as prestações descumpridas não sejam recíprocas e interdependentes, como tradicionalmente se exige para aplicação da referida exceção. Assim, qualquer atentado a uma das prestações contratuais pode significar um atentado ao sinalagma do contrato e, com isso, atingir também as demais prestações ${ }^{253}$.

A exceptio doli seria a defesa contra o dolo da outra parte. Nas palavras de MENEZES CORDEIRO, "é o poder que uma pessoa tem de repelir a pretensão do autor, por este ter incorrido em dolo" ${ }^{254}$. Em termos gerais, como aponta PONTES DE MIRANDA, a exceção material é um contra-direito, já que serve para encobrir a eficácia de direitos, pretensões, ações ou mesmo exceções contra as quais pode ser oposta ${ }^{255}$. Em nosso ordenamento, a exceção mais conhecida é aquela estabelecida pelo art. 476 do Código Civil, que introduz a exceptio non adimpleti contractus, a qual barra a eficácia de o contratante exigir a contraprestação antes de cumprir suas próprias obrigações. Não se nega a existência do direito, apenas paralisa-se o seu exercício por seu titular ${ }^{256}$.

Finalmente, o venire contra factum proprium non potest introduz a idéia de vedação do comportamento contraditório, ou seja, um sujeito não pode querer se beneficiar de uma situação que ele mesmo causou, não pode querer exercer uma posição jurídica em

\footnotetext{
${ }^{251}$ Cf. TARTUCE, Flavio. Função social dos contratos: do Código de Defesa do Consumidor ao Código Civil de 2002, cit., p. 203-205.

${ }^{252}$ Cf. Id. Ibid., p. 205.

${ }^{253}$ Cf. CORDEIRO, António Manuel da Rocha e Menezes. op. cit., v. 2, p. 844-847.

${ }^{254}$ Id. Ibid., v. 2, p. 720.

${ }^{255}$ Cf. MIRANDA, Francisco Cavalcanti Pontes de. Tratado de direito privado. 4. ed. São Paulo: Ed. Revista dos Tribunais, 1983. t. 6, p. 6.

${ }^{256} \mathrm{Cf}$. ZANETTI, Cristiano de Sousa. Responsabilidade pela ruptura das negociações, cit., p. 111-112.
} 
contradição com o seu próprio comportamento anteriormente exercido ${ }^{257}$. Para LUCIANO CAMARGo PENTEADO, o venire contra factum proprium apresenta quatro pressupostos, a saber: (i) a existência de um comportamento; (ii) a geração de uma expectativa em razão do referido comportamento; (iii) o investimento, econômico ou não, de uma das partes na expectativa gerada ou causada; e (iv) um comportamento contraditório ao inicial. Existem, assim, dois comportamentos lícitos, diferidos no tempo, os quais se contradizem de modo direto e não negocial, não podendo a situação, portanto, ser solucionada pelos remédios obrigacionais gerais $^{258}$. Embora tal autor não mencione expressamente o pressuposto de dano ou, no mínimo, potencial de dano gerado a partir do comportamento contraditório, é possível inferir referido pressuposto uma vez que se exige que tenha ocorrido um investimento, econômico ou não, de uma das partes na expectativa gerada ou causada ${ }^{259}$.

Segundo o Enunciado 362 do Conselho da Justiça Federal, "a vedação do comportamento contraditório (venire contra factum proprium) funda-se na proteção da confiança, como se extrai dos arts. 187 e 422 do Código Civil’".

Além dos conceitos acima mencionados, vale citar ainda o Enunciado 169 do Conselho da Justiça Federal. Tal enunciado, cuja origem é o art. 77 da Convenção Internacional de Viena, que trata da compra e venda internacional de mercadorias, introduz o conceito de duty to mitigate the $\operatorname{loss}^{260}$, ou seja, o credor tem o dever de evitar o próprio

${ }^{257}$ Cf. CORDEIRO, António Manuel da Rocha e Menezes. op. cit., v. 2, p. 742.

${ }^{258}$ Cf. LUCIANO CAMARGO PENTEADO apud TARTUCE, Flavio. A boa-fé objetiva e os amendoins: um ensaio sobre a vedação do comportamento contraditório (venire contra factum proprium non potest). Disponível em: <http://www.flaviotartuce.adv.br/secoes/artigos.asp>. Acesso em: 22 dez. 2008.

259،A locução venire contra factum proprium traduz o exercício de uma posição jurídica em contradição com o comportamento assumido anteriormente pelo exercente" (AZEVEDO, Antonio Junqueira de. A lesão como vício do negócio jurídico. A lesão entre comerciantes. Formalidades pré-contratuais. Proibição de venire contra factum proprium e ratificação de atos anuláveis. Resolução ou revisão por fatos supervenientes. Excessiva onerosidade, base do negócio e impossibilidade da prestação. [Parecer]. In: . Estudos e pareceres de direito privado. São Paulo: Saraiva, 2004. p. 118). Nesse sentido também, JUNQUEIRA DE AZEVEDO explica que o princípio da boa-fé, que veio corrigir eventuais excessos do subjetivismo individualista, além de impedir o venire contra factum proprium, impõe também a manutenção de uma linha de conduta uniforme, quer a pessoa esteja na posição de credor quer na de devedor, idéia conhecida pela doutrina alemã como tu quoque (Cf. AZEVEDO, Antonio Junqueira de. Interpretação do contrato pelo exame da vontade contratual. O comportamento das partes posterior à celebração. Interpretação e efeitos do contrato conforme o princípio da boa-fé objetiva. Impossibilidade de venire contra factum proprium e de utilização de dois pesos e duas medidas (tu quoque). Efeitos do contrato e sinalagma. A assunção pelos contratantes de riscos específicos e a impossibilidade de fugir do "programa contratual" estabelecido. [Parecer]. In: . Estudos e pareceres de direito privado, cit., p. 168-169).

${ }^{260}$ No Direito Comparado, há grandes discussões sobre a natureza jurídica do dever de o credor mitigar o próprio prejuízo, mas, no ordenamento pátrio, parece mais coerente, diante da concepção cooperativa de contrato vigente desde o antigo Código Civil de 1916, entendê-lo como um dever anexo, derivado do princípio da boa-fé objetiva (Cf. TARTUCE, Flavio. A boa-fé objetiva e a mitigação do prejuízo pelo credor. Esboço do tema e primeira abordagem. Disponível em: <http://www.flaviotartuce.adv.br/secoes/artigos.asp>. Acesso em: 22 dez. 2008). 
prejuízo, diante da boa-fé. Se assim não o fizer, será a ele atribuída uma culpa delitual a gerar redução do valor da dívida ou perdas e danos ${ }^{261}$.

Tal conceito está em linha com o princípio da eticidade, que norteou a elaboração do Código Civil de 2002, relacionando-se diretamente com o dever anexo de lealdade, imposto pela boa-fé objetiva ${ }^{262}$.

TARTUCE cita como exemplo o caso de uma instituição financeira que, diante do inadimplemento do devedor, permanece inerte, aguardando a dívida atingir valores astronômicos pela aplicação dos juros e encargos moratórios. Em tal situação, caberia ao juiz reduzir o valor da dívida ${ }^{263}$. Também os arts. 769 e 771 do Código Civil espelham o duty to mitigate the loss, ao determinar que o segurado é obrigado a comunicar ao segurador, logo que saiba, todo incidente suscetível de agravar, consideralmente, o risco coberto, bem como deverá informar o sinistro ao segurador logo que o saiba, tomando as providências imediatas para diminuir as consequiências, sob pena de perder a indenização.

Nota-se que o Código Civil de 2002, ao introduzir os princípios sociais e as cláusulas gerais, abriu um campo muito mais extenso para a atuação do magistrado no momento da interpretação contratual. Essa atuação, não obstante, deve ser pautada pelos critérios estabelecidos em lei e no sistema como um todo, sejam eles subjetivos ou objetivos. Não é permitido ao juiz fazer uso de critérios pessoais de justiça, tampouco afastar a vontade das partes em nome de um suposto interesse social prevalente, sem qualquer respaldo legal ${ }^{264}$.

\subsubsection{Interpretação dos contratos interempresariais}

A interpretação dos contratos interempresariais deve ter por base, além de alguns princípios peculiares do direito empresarial, as regras e princípios aplicáveis a todo e

\footnotetext{
${ }^{261}$ TARTUCE, porém, entende que não se trata de culpa delitual, no caso, mas sim de responsabilidade objetiva (TARTUCE, Flavio. Sentença: a boa-fé objetiva e o dever do credor de mitigar a perda (duty to mitigate the loss), cit., p. 66).

${ }^{262}$ Cf. Id. Ibid., p. 59-60.

${ }^{263} \mathrm{Cf}$. Id. A boa-fé objetiva e a mitigação do prejuízo pelo credor. Esboço do tema e primeira abordagem, cit., e Id. Sentença: a boa-fé objetiva e o dever do credor de mitigar a perda (duty to mitigate the loss), cit., p. 61.

${ }^{264}$ Cf. CUNHA, Daniel Sica da. op. cit., p. 276-277 e 280.
} 
qualquer contrato $^{265}$. Assim, a evolução principiológica verificada no direito contratual nos últimos anos trouxe também repercussões no âmbito dos contratos interempresariais, aplicando-se a estes todas as considerações feitas acima.

Diferentemente do pensamento liberal-clássico anterior, portanto, cabe ao magistrado, agora, interpretar o contrato e adaptá-lo à realidade sócio-econômica, em linha com os princípios presentes no ordenamento e tendo em vista toda a lógica do sistema, e não somente o interesse das partes. Contudo, no caso dos contratos interempresariais, a flexibilização da interpretação dos contratos deve ser feita com cautela ainda maior, já que se parte do pressuposto de que os empresários não são hipossuficientes e têm plenos conhecimentos do ramo em que atuam ${ }^{266}$. Assim, o juiz deve sopesar os princípios, sem modificar o que foi contratado sob justificativas infundadas.

O direito empresarial, ramo autônomo do Direito Privado, sofreu, ao longo do tempo, uma evolução que lhe conferiu uma lógica própria, fundada, principalmente, na segurança jurídica das trocas mercantis, na confiança entre as partes contratantes e na previsibilidade do comportamento dos demais agentes do mercado, elementos essenciais para o desenvolvimento do comércio e aumento do fluxo econômico.

Para consolidar tais elementos, princípios peculiares desse ramo do direito foram surgindo e sendo aplicados ao longo do tempo, dentre os quais é possível apontar a boa-fé objetiva, a legítima expectativa e os usos e costumes comerciais (que não são propriamente um princípio) $)^{267}$.

Antes da entrada em vigor do Código Civil de 2002, os contratos interempresariais, que obedecem a uma lógica própria, como visto, tinham sua base de interpretação no art. 131 do Código Comercial de 1850, o qual dispunha que:

\footnotetext{
${ }^{265}$ PABLO STOLZE e PAMPLONA FILHO, tratando das regras gerais sobre interpretação dos contratos, concluem que "dada a nova concepção do contrato na sociedade contemporânea, em que a autonomia da vontade não é mais vista como um dogma, não temos a menor sombra pálida de dúvida de que o que aqui se trabalhou é aplicável a qualquer relação jurídica contratual, uma vez que sua teoria geral abarca contratos de qualquer natureza, sejam civis, comerciais, trabalhistas e consumeristas" (GAGLIANO, Pablo Stolze; PAMPLONA FILHO, Rodolfo. Novo curso de direito civil: contratos. 3. ed. São Paulo, Saraiva, 2007. v. 4, t. 1, p. 177).

${ }^{266}$ Isso nem sempre é verdade, conforme foi explicitado no capítulo sobre a dependência econômica no âmbito contratual, mas, sempre que o sujeito, ainda que empresário, estiver sujeito a uma situação de dependência/vulnerabilidade, tal situação deverá ser comprovada no caso concreto.

${ }^{267}$ Existem outros princípios peculiares do direito empresarial, tal como o cosmopolitismo, a rapidez/celeridade e o informalismo/simplicidade, mas estes acabam, de certa forma, por integrar os usos e costumes, de forma que optou-se por tratar somente deste último.
} 
"Art. 131 - Sendo necessário interpretar as cláusulas do contrato, a interpretação, além das regras sobreditas, será regulada sobre as seguintes bases:

1 - a inteligência simples e adequada, que for mais conforme à boa fé, $e$ ao verdadeiro espírito e natureza do contrato, deverá sempre prevalecer à rigorosa e restrita significação das palavras;

2 - as cláusulas duvidosas serão entendidas pelas que o não forem, e que as partes tiverem admitido; $e$ as antecedentes e subseqüentes, que estiverem em harmonia, explicarão as ambíguas;

3 - o fato dos contraentes posterior ao contrato, que tiver relação com o objeto principal, será a melhor explicação da vontade que as partes tiverem no ato da celebração do mesmo contrato;

4 - o uso e prática geralmente observada no comércio nos casos da mesma natureza, e especialmente o costume do lugar onde o contrato deva ter execução, prevalecerá a qualquer inteligência em contrário que se pretenda dar às palavras;

5 - nos casos duvidosos, que não possam resolver-se segundo as bases estabelecidas, decidir-se-á em favor do devedor."

Tal artigo expressava os princípios que deveriam ser aplicados sempre que surgisse alguma incerteza no negócio jurídico celebrado, tais como a boa-fé, os usos e costumes e a verdadeira natureza do contrato.

A boa-fé objetiva, hoje difundida em todos os ramos do direito, especialmente após a entrada em vigor do Código Civil de 2002, desde há muito já era aplicada no âmbito empresarial, com o intuito de se perquirir o padrão de comportamento do homem ativo e probo, provendo maior previsibilidade e segurança entre os contraentes, como forma de se diminuir os custos de transação e colaborar para o desenvolvimento econômico.

Por esse princípio, dever-se-ia analisar se os agentes econômicos estavam cumprindo sua função de forma adequada, se estavam tomando as diligências necessárias para o exercício da profissão, se estavam adotando uma linha correta e honesta, não sendo tão importante buscar a intenção do agente quando da celebração do negócio jurídico ${ }^{268}$.

Como a real vontade ficava afastada da análise, levava-se em conta os hábitos comuns de determinado lugar ou determinada profissão como critério de avaliação de existência da boa-fé, conferindo-se maior grau de previsão às ações do agente com o qual se contratava. Tal critério nada mais era do que os usos e costumes comerciais, restando patente a forte relação existente entre estes e a boa-fé objetiva na interpretação dos

\footnotetext{
${ }^{268}$ Cf. STAGNI, Alexandre; NOGUEIRA, André Coutinho; CABELEIRA, Caio; OUCHANA, Elber Christian; GOMES, Guilherme Amado. op. cit., p. 221-222.
} 
contratos interempresariais $^{269}$. Daí porque, em matéria comercial, costumava-se tratar os usos e costumes tal qual um princípio geral de direito ${ }^{270}$.

Os usos comerciais passavam a existir com a constante utilização de certas cláusulas nos contratos celebrados em determinada região ou por determinada classe de comerciantes. Tais cláusulas, após longa data sendo utilizadas, deixavam de ser mencionadas expressamente nos contratos, considerando-se a eles implícitas ${ }^{271}$. Alguns autores costumam diferenciar os costumes dos usos, alegando que o costume é a positivação do uso $^{272}$.

A utilização dos usos e costumes, não obstante, devia se dar apenas de forma supletiva, a completar eventuais lacunas ou deficiências da lei, e de forma alguma poderia contrariar texto legal expresso ${ }^{273}$.

CARVALHo DE MENDONÇA elencava três elementos fundamentais para que os usos e costumes fossem legítimos, a saber: (i) que fossem praticados constantemente sem divergência a todos os casos semelhantes entre os comerciantes de determinada praça; (ii) que estivessem de acordo com a boa-fé e as "máximas comerciais"; e (iii) que não contrariassem as leis comerciais, podendo, todavia, ser contrários às leis civis, desde que estas não fossem por lei comercial expressamente aplicáveis à matéria mercantil. Mas, somados a esses elementos, ainda deveria ser exigido um quarto requisito, conhecido como opinio juris seu necessitatis. Consistia este num fator psicológico, imaterial, caracterizado pela convicção de que o uso comercial teria de ser observado como se obedecesse a um dispositivo legal. Assim, não deveriam constituir usos legítimos as práticas observadas por condescendência, tolerância, liberalidade ou admitidas por negligência ${ }^{274}$.

\footnotetext{
${ }^{269}$ Cf. STAGNI, Alexandre; NOGUEIRA, André Coutinho; CABELEIRA, Caio; OUCHANA, Elber Christian; GOMES, Guilherme Amado. op. cit., p. 222.

${ }^{270}$ Acerca da utilização dos usos e costumes como norte para a celebração das relações comerciais, vide: RE 79.545-BA, $1^{\text {a }}$ Turma, Rel. Min. Aliomar Baleeira, j. 22/11/74. Em tal acórdão, um produtor de cacau que havia firmado contrato a termo para a venda do cacau produzido tentou alegar que a venda havia sido celebrada de modo absolutamente informal, razão pela qual poderia aumentar o preço do produto quando da efetiva tradição. A $1^{\text {a }}$ Turma do STF, contudo, entendeu que este tipo de pacto a termo era de uso muito antigo entre os fazendeiros da Bahia e o singelo "pedido" caracterizava o único "documento" a comprovar a quantidade, o preço e a data de entrega acordados para a transação, não sendo possível ao produtor, posteriormente, alterar qualquer um desses elementos de forma unilateral.

${ }^{271}$ Cf. MENDONÇA, José Xavier Carvalho de. Tratado de direito comercial brasileiro. 3. ed. Rio de Janeiro: Freitas Bastos, 1937. v. 1, p. 183.

${ }^{272}$ Cf. STAGNI, Alexandre; NOGUEIRA, André Coutinho; CABELEIRA, Caio; OUCHANA, Elber Christian; GOMES, Guilherme Amado. op. cit., p. 224.

${ }^{273}$ Cf. MENDONÇA, José Xavier Carvalho de. op. cit., v. 1, p. 182.

${ }^{274}$ Cf. Id. Ibid., p. 182-185.
} 
Este último requisito, com a unificação do direito civil e empresarial a partir da entrada em vigor do Código Civil de 2002, deverá ser adaptado, de forma que todos os dispositivos de tal código aplicáveis à matéria comercial também não poderão ser contrariados, ainda que não haja lei comercial expressa nesse sentido.

Além das regras do art. 131 supra transcrito, os contratos interempresariais deviam ser interpetados levando-se em conta as expectativas oriundas do próprio mercado. Existe uma racionalidade econômica inerente aos empresários que, ao contratarem, esperam uma certa conduta dos demais agentes do mercado. Nesse sentido, foi consolidado na jurisprudência o entendimento de que a legítima expectativa deveria ser respeitada, não cabendo aos juizes ferir de forma avassaladora a lógica empresarial ${ }^{275}$. Eventualmente, poderia o magistrado deixar de lado o princípio da legítima expectativa, desde que houvesse fundados motivos para tanto, que estivessem em linha com a função social e econômica do contrato.

Ademais, a função econômica do negócio jurídico, além de sua função social, sempre foi de extrema relevância nos contratos interempresariais. Conforme nos ensina a teoria dos jogos, o agente econômico prevê suas jogadas com base no comportamento esperado dos demais agentes, de forma a criar um sistema com bases sólidas e seguras, objetivando-se o comportamento de seus participantes ${ }^{276}$.

Tendo em mente que o risco da atividade é pressuposto do ramo empresarial, a interpretação desses contratos pelo aplicador do direito deverá perseguir a exclusão dos danos provenientes de situações imprevisíveis ou de abusos por parte do contratante economicamente mais forte, que, por sua vez, trariam prejuízos ao mercado e à economia em geral. Todavia, tal interpretação em hipótese alguma poderá ter como ímpeto anular por completo o risco inerente ao sistema ${ }^{277}$.

A lógica do agente econômico (do homem ativo e probo) evoluiu durante séculos de trocas mercantis, consolidando uma base sólida que possibilita a atuação no mercado com segurança jurídica. A interpretação dos contratos interempresariais, por conseguinte,

\footnotetext{
${ }^{275}$ Cf. STAGNI, Alexandre; NOGUEIRA, André Coutinho; CABELEIRA, Caio; OUCHANA, Elber Christian; GOMES, Guilherme Amado. op. cit., p. 217.

${ }^{276}$ Tal teoria recebe algumas críticas, mas de forma geral deve ser levada em consideração. Sobre as diversas teorias aplicáveis aos comportamentos, vide: SALOMÃO FILHO, Calixto. op. cit., p. 22-36.

${ }^{277}$ Cf. STAGNI, Alexandre; NOGUEIRA, André Coutinho; CABELEIRA, Caio; OUCHANA, Elber Christian; GOMES, Guilherme Amado. op. cit., p. 217.
} 
deve obedecer a essa mentalidade, propiciando, dessa maneira, a manutenção do $\operatorname{mercado}^{278}$.

De fato, o Poder Judiciário já havia consolidado suas decisões, pautando-se nos princípios e na lógica do sistema acima abordados. Com a entrada em vigor do Código Civil de 2002 e a revogação do citado art. 131 do Código Comercial de 1850, porém, instaurou-se um momento de incerteza, não sendo possível afirmar se tais parâmetros serão mantidos, uma vez que o texto legislativo é outro. Restará ao magistrado o papel de solidificar uma nova jurisprudência, em relação aos artigos do Código Civil que tratam da interpretação dos contratos, sem, contudo, desvirtuar a lógica empresarial e levando em conta, sempre que possível, a jurisprudência do antigo Código Comercial.

\subsubsection{Insuficiência dos institutos do Código Civil}

Além dos novos princípios sociais e da disciplina das cláusulas abusivas prevista no art. 424 do Código Civil, que será tratada em capítulo específico, o Código Civil trouxe alguns mecanismos especialmente dedicados à correção dos abusos praticados em âmbito contratual e dos desequilíbrios gerados, dentre os quais se destacam a resolução por onerosidade excessiva, a lesão e o abuso de direito.

A onerosidade excessiva é um remédio para os desequilíbrios surgidos após a celebração do contrato. Tal instituto já estava previsto no CDC em seu art. $6^{\circ}, \mathrm{V}$, e passou a ser também regulado pelo Código Civil de 2002, todavia com critérios mais rigorosos do que aqueles exigidos pelo $\mathrm{CDC}$.

No Código Civil, a onerosidade excessiva está prevista no art. 317, que possibilita a revisão judicial do valor da prestação em razão de desproporção manifesta surgida por motivos imprevisíveis, e no art. 478, que disciplina a resolução do contrato por onerosidade excessiva. Sempre que possível, porém, o art. 478 deverá conduzir também à revisão judicial do contrato, e não a sua resolução, em linha com o princípio da conservação dos negócios jurídicos ${ }^{279}$.

\footnotetext{
${ }^{278}$ Cf. STAGNI, Alexandre; NOGUEIRA, André Coutinho; CABELEIRA, Caio; OUCHANA, Elber Christian; GOMES, Guilherme Amado. op. cit., p. 218.

${ }^{279} \mathrm{O}$ Enunciado 176 do Conselho da Justiça Federal determina que: “Art. 478: Em atenção ao princípio da conservação dos negócios jurídicos, o art. 478 do Código Civil de 2002 deverá conduzir, sempre que possível, à revisão judicial dos contratos e não à resolução contratual."
} 
Tais artigos introduzem em nosso ordenamento os conceitos da Teoria da Imprevisão, ao adotar como critérios para a aplicação da onerosidade excessiva a necessidade de: (i) o contrato ser bilateral, sinalagmático e oneroso; (ii) o contrato ser comutativo, e não aleatório; (iii) o contrato ser de trato sucessivo (execução diferida ou continuada); (iv) comprovar-se a presença de um motivo imprevisível e/ou extraordinário; e (v) comprovar-se uma desproporção negocial ou quebra do sinalágma (onerosidade excessiva para um dos contratantes).

A Teoria da Imprevisão é uma evolução da antiga cláusula rebus sic stantibus. Nos contratos permanentes, entendia-se haver uma cláusula subentendida - a cláusula rebus sic stantibus - segundo a qual uma convenção só permaneceria em vigor enquanto o estado de coisas existente no momento em que houvesse sido estabelecida não fosse objeto de modificações essenciais.

Essa cláusula teve espaço até meados do século XVIII, quando entrou em franca e irreversível decadência. Seu interesse daí até a Primeira Guerra Mundial, quando o pacta sunt servanda atingiu o seu auge, passou a ser meramente histórico. Foi somente após a guerra de 1914 que se reconvocou a cláusula para atuar como fiel da balança da justiça comutativa, agora com a roupagem moderna de Teoria da Imprevisão, ganhando, por fim, a importância e relevância há muito merecidas ${ }^{280}$.

Com efeito, os fundamentos dessa teoria são de tamanha relevância para o mundo negocial moderno que, atualmente, é muito pouco questionada a sua aplicação, quando verificados seus pressupostos. SERPA LOPES bem sintetizou a importância e validade da Teoria da Imprevisão, considerando intuitiva a justiça dessa teoria e a necessidade imperiosa de sua aplicação prática na lei entre as partes. Segundo o autor, o contrato, do mesmo modo que a lei, pode encontrar-se, no curso de sua existência, em desacordo com as suas finalidades econômicas, por força de acontecimentos anormais supervenientes. Em face disso, assim como ao juiz, sem se desviar da lei, cabe o dever de interpretá-la em conformidade com a nova situação social em conflito com a norma de direito positivo, igual papel deve assistir-lhe quando o contrato se encontrar na mesma posição ${ }^{281}$.

A Teoria da Imprevisão, portanto, tem seu campo de aplicação quando uma das partes assume um ônus excessivo decorrente de um evento superveniente que as partes não

\footnotetext{
${ }^{280} \mathrm{Cf}$. BORGES, Nelson. A teoria da imprevisão no direito civil e no processo civil. São Paulo: Malheiros Ed., 2002. p. 110-145.

${ }^{281}$ Cf. SERPA LOPES apud KLANG, Marcio. A teoria da imprevisão e a revisão dos contratos. São Paulo: Ed. Revista dos Tribunais, 1983.p. 44-45.
} 
puderam prever ao tempo da contratação. O evento há de ser tão imprevisível que, se as partes o pudessem prever, não teriam celebrado o negócio, ao menos não nos termos pactuados. E mais, o evento deve ser de tal natureza que se rompa inteiramente a equivalência das prestações existente à data da contratação originária do negócio jurídico subjacente. A Teoria da Imprevisão, portanto, é uma das principais exceções legais ao princípio do pacta sunt servanda, em virtude do qual os contratos devem ser cumpridos tal como foram celebrados 282 .

A idéia de revisão judicial das cláusulas contratuais ou mesmo da resolução por excessiva onerosidade está presente, atualmente, em praticamente todos os ordenamentos, cada qual com um nome próprio. No direito italiano, por exemplo, não se fala em Teoria da Imprevisão, e sim em excessiva onerosidade, porém, na prática, os dispositivos desse ordenamento e os do direito brasileiro tratam exatamente do mesmo instituto. Nessa esteira, o artigo 1.467 do Código Civil italiano prevê que poderá haver resolução do contrato sinalagmático "se la prestazione di una delle parti è divenuta eccessivamente onerosa per il verificarsi di avvenimenti straordinari ed imprevedibili".

A ocorrência de acontecimentos imprevisíveis e desvinculados da vontade das partes, que tornem muito difícil ou excessivamente onerosa a prestação de um dos contratantes, facultará à parte prejudicada, nos termos dessa teoria, pleitear a revisão judicial das cláusulas contratuais, com o fim de ajustá-las à nova realidade, restabelecendo o equilíbrio contratual e, em última instância, pleitear a resolução do negócio celebrado ${ }^{283}$.

Não é qualquer desequilíbrio superveniente, no entanto, que está sujeito à aplicação da Teoria da Imprevisão. Como bem advertiu ORLAndo Gomes, a extensão da aplicabilidade da imprevisão a todas as situações de superveniente desequilíbrio contratual significa, na realidade, a negação da própria teoria, pois há situações de desequilíbrio de prestações mais do que previsíveis, senão prováveis, como aquelas existentes em regimes de intensa inflação ${ }^{284}$. Logo, não cabe falar em Teoria da Imprevisão como base ordinária de revisão dos contratos cujas prestações perderam a equivalência por influência da espiral inflacionária, por exemplo ${ }^{285}$.

\footnotetext{
${ }^{282}$ Cf. ANDRADE JR., Attila de Souza Leão. Comentários ao novo Código Civil: parte geral. Rio de Janeiro: Forense, 2004. v. 1, p. 220.

${ }^{283}$ Cf. KLANG, Marcio. op. cit., p. 17.

${ }^{284} \mathrm{Cf}$. GOMES, Orlando. Transformações gerais do direito das obrigações. São Paulo: Ed. Revista dos Tribunais, 1980. p. 148.

${ }^{285}$ Cf. KLANG, Marcio. op. cit., p. 39.
} 
Para a aplicação da teoria em comento, é preciso fazer a distinção entre evento extraordinário e imprevisível, capaz de fundamentar a resolução do contrato por excessiva onerosidade sobrevinda, da álea normal do contrato que, no caso dos contratos interempresariais, é representada, em primeiro lugar, pelo risco de empresa, do qual o empresário não pode pretender se esquivar ${ }^{286}$.

O grande problema advém do termo "imprevisível”, pois a jurisprudência vinha interpretando o "fato imprevisível" tendo por parâmetro o mercado, o que tornava praticamente impossível essa forma de revisão, pois, hoje, pode-se dizer que praticamente tudo é previsível, especialmente no campo econômico ${ }^{287}$. O resultado disso foi a publicação dos enunciados 17 e 175 do Conselho da Justiça Federal. O primeiro deles estabelece que a expressão "motivos imprevisíveis" constante do art. 317 deve abarcar tanto causas de desproporção não previsíveis, como também aquelas previsíveis, mas de resultados imprevisíveis. O fato imprevisível, portanto, deve ser analisado tendo como parâmetro não o mercado, mas a pessoa do contratante, se ele previa ou não o resultado quando celebrou o contrato. A utilização do mercado como parâmetro tornaria praticamente impossível a revisão ou resolução do contrato por onerosidade excessiva no Código Civil, pois o desemprego, a escala inflacionária, a alta do dólar etc. não podem ser considerados fatos imprevisíveis para o mercado. O segundo deles, por sua vez, determina que a menção à imprevisibilidade e à extraordinariedade, insertas no art. 478 do Código Civil, deve ser interpretada não somente em relação ao fato que gere o desequilíbrio, mas também em relação às conseqüências que ele produz.

A partir dos Enunciados acima mencionados, a revisão contratual prevista pelo Código Civil acabou por se aproximar em grande parte da revisão prevista no CDC. O art. $6^{\circ}, \mathrm{V}$, de tal diploma legal dispensa a prova do fato imprevisível, aproximando-se, portanto, da Teoria da Base do Negócio Jurídico, de KARL LARENZ ${ }^{288}$. TARTUCE aponta que a possibilidade de se rever um contrato por simples onerosidade, no âmbito do CDC, não sendo necessária a presença de um fato imprevisível ${ }^{289}$, está em linha:

\footnotetext{
${ }^{286}$ Cf. FRIGNANI, Aldo. Il contratto di franchising. Milano: Giuffrè, 1999. p. 177.

${ }^{287}$ Cf. TARTUCE, Flavio. Função social dos contratos: do Código de Defesa do Consumidor ao Código Civil de 2002, cit., p. 340.

${ }^{288}$ Esse é também o entendimento de TARTUCE, conforme pode-se denotar do seguinte artigo: A revisão do contrato no Código de Defesa do Consumidor e a suposta adoção da teoria da imprevisão: visão frente ao princípio da função social do contrato, cit. No mesmo sentido, TARTUCE, Flavio. Função social dos contratos: do Código de Defesa do Consumidor ao Código Civil de 2002, cit., p. 125-133.

${ }^{289}$ Da mesma forma, CÍNTIA ROSA, explica que "a teoria da imprevisão e a teoria da onerosidade excessiva, em que o princípio da força obrigatória do contrato é afastado, fundamentam-se na noção de equidade, em
} 
“(...) com o princípio da equidade contratual, trazido pela tendência de socialização do direito, pela valorização da dignidade da pessoa humana, pela solidariedade social, pela igualdade material que deve sempre estar presente nos negócios. Dessa forma, utiliza-se os princípios do direito civil constitucional para fundamentar a possibilidade de revisão dessa forma. Também, tal forma de revisão está amparada no que consta no art. 170, III, da Carta Política: a busca da justiça social, um dos princípios gerais da atividade econômica" ${ }^{290}$.

Para muitos autores, o Código Civil de 2002, muito embora tenha introduzido expressamente em nosso ordenamento os princípios sociais, representou, por outro lado, um retrocesso, na medida em disciplinou institutos já previstos anteriormente no CDC, conferindo, porém, uma conformação bem mais restritiva ${ }^{291}$. Esse foi um dos motivos pelos quais o Conselho da Justiça Federal tentou flexibilizar a exigência, feita pelo Código Civil, de comprovação do fato imprevisível para a aplicação da onerosidade excessiva nos contratos celebrados entre iguais. De todo modo, não é de se desprezar o fato de que os requisitos positivados pelo Código Civil continuam sendo mais rigorosos que os do CDC, como explanado nas linhas acima.

O Código Civil de 2002, ainda, prevê o instituto jurídico da lesão, o qual, como visto no item 4.1 deste estudo, permite a anulação do negócio jurídico celebrado sob premente necessidade, ou por inexperiência de uma das partes, que acaba por se obrigar a prestação manifestamente desproporcional ao valor da prestação oposta.

O instituto jurídico da lesão é relativamente novo em nosso ordenamento jurídico. Durante muito tempo se pensou que tal instituto não integraria o sistema de direito comercial. CAIRU já defendia esse posicionamento, afirmando que a lesão não deveria ser empregada quando se tratasse de negócios havidos entre comerciantes, e não destes com o público em geral. O próprio Código Comercial brasileiro, atualmente revogado, previa em seu artigo 220 que "a rescisão por lesão não tem lugar nas compras e vendas celebradas entre pessoas todas comerciantes; salvo provando-se erro, fraude ou simulação"292.

\footnotetext{
outras palavras, na justiça contratual" (LIMA, Cíntia Rosa Pereira de. Nova principiologia contratual interpretada pela jurisprudência moderna: decadência do dogma pacta sunt servanda. In: Hironaka, Giselda Maria Fernandes Novaes (Coord.). A outra face do Poder Judiciário: decisões inovadoras e mudanças de paradigmas. Belo Horizonte: Del Rey, 2007. v. 2, p. 38).

${ }^{290}$ TARTUCE, Flavio. A revisão do contrato no Código de Defesa do Consumidor e a suposta adoção da teoria da imprevisão: visão frente ao princípio da função social do contrato, cit.

${ }^{291}$ Nesse sentido, vide: NEGREIROS, Teresa. op. cit., p. 316.

${ }^{292}$ Cf. FORGIONI, Paula Andréa. Contrato de distribuição, cit., p. 442-444.
} 
Com o advento do Código Civil de 2002, que regula tanto os contratos civis quanto os empresariais, porém, a previsão do instituto jurídico da lesão em caráter geral deverá fazer com que este instituto passe a ser aplicado a todos os contratos regulados por esse código. No caso dos contratos interempresariais, contudo, a doutrina majoritária vem concebendo uma aplicação restrita desse instituto, como se verá a seguir.

A lesão, segundo AtTILA DE SouZA LEÃO, pode ser conceituada como um rompimento abrupto no valor da prestação e da contraprestação, ou seja, no princípio da equivalência das prestações, acarretando, para uma das partes, uma perda patrimonial substancial, em decorrência dessa pessoa ter celebrado o acordo sob premente necessidade ou por inexperiência ${ }^{293}$.

Assim, diferentemente do estado de perigo, pode ocorrer lesão também fora do contexto da premência do perigo ou da necessidade, já que a lesão pode se dar também pela inexperiência da parte que assumiu a desproporcionalidade da prestação. E, nesse caso, pode-se dizer que a teoria da lesão resvala também pelo aspecto ético aproximando-se, portanto, do instituto do dolo - de alguém que, aproveitando-se da inexperiência da outra parte, aufere vantagem em detrimento do interesse daquela supostamente inexperiente ${ }^{294}$.

Difere o instituto jurídico da lesão também da aplicação da Teoria da Imprevisão. Esta, tal qual a lesão, funda-se na onerosidade excessiva, isto é, na quebra do equilíbrio entre prestação e contraprestação no contrato bilateral. A grande diferença entre os dois institutos, porém, reside no momento em que o desequilíbrio se instala no negócio jurídico. A Teoria da Imprevisão terá aplicação sempre que esse desequilíbrio se verificar durante a fase de execução do contrato, por alterações econômicas supervenientes. É justamente por isso que seu campo de aplicação é somente entre os contratos de execução diferida ou de trato sucessivo. A lesão, por outro lado, é um defeito congênito do negócio jurídico. $\mathrm{O}$ contrato bilateral sofre a quebra do sinalagma já em sua formação e, portanto, é a validade do negócio que se apresenta comprometida ${ }^{295}$.

O atual Código Civil brasileiro, ao prever o instituto jurídico da lesão como um vício de consentimento, permite a anulação e/ou a revisão do contrato ${ }^{296}$ quando uma parte

\footnotetext{
${ }^{293}$ Cf. ANDRADE JR., Attila de Souza Leão. op. cit., p. 218.

${ }^{294}$ Cf. Id. Ibid., p. 219.

${ }^{295}$ Cf. THEODORO JR., Humberto, op. cit., v. 2, t. 1, p. 243-244.

${ }^{296}$ Cumpre ressaltar que o caput do artigo 157 do Código Civil pode levar a entender que à parte prejudicada caberia apenas o pedido de anulação do contrato, restando à parte beneficiada a faculdade de salvá-lo
} 
sofre uma lesão desproporcional no aspecto financeiro ou custo do objeto, sendo que, nesse caso, o elemento subjetivo que perfaz o erro ou o dolo na captação da vontade não é relevante. Além da desproporção do valor, um dos requisitos exigidos para a incidência do instituto jurídico da lesão é a premente necessidade ou a inexperiência da parte, entendida esta última como "a situação de desigualdade técnico-científica ou transacional que existe entre as partes e que vai ser aproveitada pela mais forte e mais conhecedora, em detrimento da mais débil (...),297.

É possível identificar, portanto, três elementos necessários para que se configure a lesão, a saber: (a) o elemento objetivo, que consiste na desproporção manifesta entre as prestações recíprocas, capaz de proporcionar lucro exagerado e incompatível com a normal comutatividade do contrato; (b) o elemento subjetivo, que vem a ser a deficiência das condições psicológicas do contratante presentes no momento da declaração negocial, consistente em inexperiência ou premente necessidade (ao contrário do dolo, aqui o contratante não induz o outro à prática do ato lesivo, mas apenas tira proveito de sua situação) e, finalmente, (c) o nexo causal entre a deficiência da formação da vontade e a conclusão do contrato lesivo $^{298}$.

O desequilíbrio entre as prestações, além de ter de decorrer do estado de premente necessidade ou de inexperiência de uma das partes, bem como de ser congênito, e não fruto de oscilações de mercado ulteriores ao negócio, deverá, ainda, persistir até o momento da anulação, porque a lesão é daqueles defeitos que a lei permite sejam remediados $a$ posteriori. Extinta a disparidade de prestações, dessa forma, não mais haverá razão para a ruptura da avença. Porém, para que tal assertiva seja verdadeira, é preciso haver prestações ainda por satisfazer. Se a lesão já se consumou e o negócio se exauriu, pouco importa que o bem tenha se valorizado ou desvalorizado posteriormente ao contrato. Isso porque a anulação será possível em função do prejuízo que o lesado efetivamente sofreu no momento do ajuste ${ }^{299}$.

mediante suplementação ou redução do preço. Esse entendimento, porém, não deve prevalecer. Seria completamente irrazoável e contrário ao princípio da conservação do negócio jurídico - anexo ao princípio da função social dos contratos - pretender que quem pode o mais não pode o menos. Assim, apesar da redação do artigo 157 do Código Civil, à parte prejudicada cabe a possibilidade de requerer tanto a revisão quanto a anulação do contrato (Cf. TARTUCE, Flavio. Função social dos contratos: do Código de Defesa do Consumidor ao Código Civil de 2002, cit., p. 275-276).

${ }^{297}$ BECKER, Anelise. Teoria geral da lesão nos contratos. São Paulo: Saraiva, 2000. p. 124.

${ }^{298}$ Cf. THEODORO JR., Humberto, op. cit., v. 2, t. 1, p. 226-227.

${ }^{299}$ Cf. Id. Ibid., p. 226. 
Caracterizados os três elementos que compõem a lesão, por conseguinte, o contrato será anulável porque foi viciado o consentimento da parte prejudicada, mesmo que o outro contratante não tenha tido conhecimento das suas condições de necessidade ou inexperiência.

Não obstante, a doutrina nacional costuma distinguir o campo de aplicação do instituto conforme o tipo de lesão em tela. A lesão como estado de inexperiência só se aplicaria aos contratos existenciais, deixando de fora os empresários, portanto ${ }^{300}$. No tocante à lesão enquanto estado de necessidade, deve-se fazer a distinção entre necessidade de subsistência, que só tem cabimento para os contratos celebrados com pessoas físicas, e a necessidade econômica, a qual, excepcionalmente, poderá ser aplicada também a pessoas jurídicas.

Assim, em que pese certa parcimônia, a lesão poderá também ser aplicada no campo empresarial, tutelando aqueles sujeitos que, devido a uma situação de dependência econômica, acabam por aceitar condições contratuais absolutamente despropositadas por parte do contratante em posição de superioridade ${ }^{301}$.

O Código Civil de 2002, entretanto, não prevê um limite rígido para a desproporção entre as prestações, apenas afirmando que ocorrerá a lesão sempre que a prestação de uma parte for "manifestamente desproporcional ao valor da prestação oposta". Assim, caberá ao juiz, segundo prudente arbítrio, à luz dos princípios da boa-fé, da eqüidade e dos usos e costumes, completar esse conceito vago, determinando se há ou não, no caso concreto, manifesta desproporção entre as prestações.

Tal remédio, dessa forma, acaba não diferindo muito daquele que já seria oferecido pela aplicação, no caso concreto, dos novos princípios sociais, apresentando, portanto, o mesmo incoveniente de depender de conceitos vagos e subjetivos.

Ademais, vale lembrar que, pelo entendimento majoritário da doutrina nacional, a idéia de inexperiência, no instituto jurídico da lesão, somente abarcaria as pessoas físicas. Eventualmente, contudo, também os empresários poderão ficar sujeitos a abusos praticados pelo contratante em posição de superioridade quando estiverem no início de suas experiências empresariais, sendo, portanto, inexperientes em comparação com aqueles empresários que já tenham muito tempo de mercado.

\footnotetext{
${ }^{300} \mathrm{O}$ paradigma dos contratos existenciais versus contratos de lucro será explicado de forma mais detalhada no item 6.2.1 do presente estudo.

${ }^{301}$ Cf. FORGIONI, Paula Andréa. Contrato de distribuição, cit., p. 444-446.
} 
É importante mencionar que não se está a pleitear, com o presente estudo, que esse instituto seja aplicado com o intuito de liberar o empresário (ainda que em posição de dependência econômica) dos riscos que são inerentes a sua atividade, mitigando a força vinculante do contrato, mas apenas com o escopo de coibir o comportamento oportunista e contrário à ordem jurídica daquele que está em posição de superioridade ${ }^{302}$.

Finalmente, o instituto jurídico da lesão, diferentemente das cláusulas abusivas, diz respeito ao desequilíbrio econômico entre prestação e contraprestação, não se referindo a um desequilíbrio entre direitos e deveres das partes no contrato, como é o caso das cláusulas abusivas. Assim, é muito mais difícil sustentar a aplicação desse instituto aos contratos interempresariais do que a aplicação do regramento das cláusulas abusivas, tendo em vista o caráter especulativo da atividade profissional mercantil ${ }^{303}$.

O Código Civil de 2002 prevê, ainda, a concepção de abuso de direito, que consiste em se controlar o exercício de direitos por seus titulares mediante a imposição de certos limites internos.

Sem almejar um exame detalhado dessa noção, e sem cogitar das diferentes concepções possíveis, o abuso de direito diferencia-se do abuso de dependência econômica na medida em que o segundo consiste em um poder de fato, uma posição econômica exercida sobre um parceiro em situação de inferioridade, ao passo que o primeiro decorre do exercício abusivo de um direito subjetivo ${ }^{304}$.

$\mathrm{O}$ ato abusivo, portanto, não é o ato contrário ao direito, mas sim o ato contrário aos limites internos de um direito subjetivo. GUESTIN esclarece que, em matéria de abuso de direito, é preciso distinguir entre os limites externos e os internos dos direitos subjetivos. Os limites externos são os poderes descritos objetivamente pela lei, que, pela sua natureza ou seu objeto, serão por esta aceitos ou recusados. Assim, o direito que o proprietário tem de construir sobre seu próprio terreno constitui um limite objetivo e, se ele construir além dos limites de seu terreno, estará ferindo um limite externo da lei. Entretanto, as prerrogativas conferidas pela lei a um indivíduo não são absolutas. O proprietário que constrói sobre seu próprio terreno não pode construir o que quiser e da forma como quiser, ainda que não esteja desrespeitando o limite externo a ele atribuído

\footnotetext{
${ }^{302}$ Para usar as palavras de PAULA FORGIONI, cf. Id. Ibid., p. 446.

${ }^{303} \mathrm{Cf}$. AZEVEDO, Antonio Junqueira de. A lesão como vício do negócio jurídico, cit., p. 114-115.

${ }^{304}$ No mesmo sentido, vide: FORGIONI, Paula Andréa. Os fundamentos do antitruste. São Paulo: Ed. Revista dos Tribunais, 1998. p. 277.
} 
pela lei. Não pode ele, por exemplo, construir uma obra em seu terreno com o fim exclusivo de incomodar seu vizinho. Trata-se, nesse caso, de um limite interno ${ }^{305}$.

A teoria do abuso de direito tem por campo de aplicação exatamente esses casos de transgressão de um limite interno do direito subjetivo. A grande questão, então, gira em torno de se saber em que momento o titular de um direito subjetivo está transgredindo um limite interno de seu direito. Para RIPERT, os direitos subjetivos são absolutos, de forma que só uma apreciação moral permitiria sancionar excepcionalmente seu exercício abusivo. JOSSERAND, por outro lado, propôs uma concepção finalista do abuso de direito, segundo a qual os direitos subjetivos são conferidos aos indivíduos somente na medida em que forem conformes aos interesses de toda a sociedade. E exercer esse direito com a intenção de prejudicar o próximo é evidentemente contrário a essa finalidade social. Assim, permite-se um controle do exercício dos direitos com base na legitimidade do motivo que determinou o interesse de agir do titular do direito. GUESTIN não concorda com nenhuma das duas posições. Para ele, os limites internos dos direitos subjetivos são raramente formulados pela lei de forma expressa, uma vez que ela apenas enuncia as prerrogativas desse direito, de sorte que são nos princípios gerais e no espírito do sistema jurídico que se deve buscar tais limites ${ }^{306}$.

A posição de GUESTIN está em consonância com o entendimento do legislador nacional, na medida em que este definiu, em seu art. 187, como abuso de direito o exercício de um direito por seu titular que manifestamente exceda os limites impostos pelo seu fim econômico ou social, pela boa-fé ou pelos bons costumes. A solução encontrada pelo legislador nacional, entretanto, faz com que a teoria do abuso de direito não difira muito da proteção que já seria conferida pelos novos princípios sociais, e apresenta o mesmo inconveniente de tornar a análise com base em tal teoria incerta e subjetiva.

Muitos juristas vêem na cláusula abusiva a manifestação por excelência do abuso de direito no contrato. Tendo em vista que seu maior campo de incidência é o dos contratos de adesão, consubstanciar-se-iam elas, nesse caso, no exercício abusivo da faculdade de predispor os termos do contrato ${ }^{307}$. Alguns autores estrangeiros, contudo, posicionam-se contra a aplicação dessa teoria em sede de cláusulas abusivas sob o argumento de que a sanção, no caso de abusividade de uma cláusula, não é a mesma daquela que é imposta ao

\footnotetext{
${ }^{305} \mathrm{Cf}$. GUESTIN, Jacques. L'abus dans les contrats, cit., p. 2-3.

${ }^{306}$ Cf. Id. Ibid., p. 2-3.

${ }^{307}$ Cf. BITTAR, Carlos Alberto (Coord.). Os contratos de adesão e o controle de cláusulas abusivas. São Paulo: Saraiva, 1991. p. 77-78.
} 
sujeito que abusa de um direito. Este último, em geral, é condenado a ressarcir os prejuízos sofridos pela vítima, ao passo que àquele que insere uma cláusula abusiva em um contrato será imposta a nulidade da cláusula ou até mesmo de todo o contrato.

JOSSERAND, porém, ao contrário dos juristas que o precederam, reconhece uma diversidade de sanções ao abuso de direito, em particular no tocante à existência de toda uma gama de sanções in natura. Para esse autor, estas últimas, além da função reparativa, teriam também por objetivo prevenir e reprimir a prática de novos atos abusivos. JOSSERAND reconhece, ainda, que, em alguns casos, a sanção pode ser a própria anulação do ato abusivo. Nesse sentido, a grande diferença entre o abuso de direito e o ato ilegal residiria no fato de que, ao contrário deste, o ato abusivo não pode ser sancionado senão quando a vítima houver sofrido efetivamente um prejuízo ${ }^{308}$.

A disciplina do abuso de direito instituída pelo Código Civil de 2002 faz minar toda essa discussão, na medida em que o art. 187 do referido diploma legal determina que o ato cometido com abuso de direito é um ato ilícito, fulminando-se a este a nulidade, nos termos do art. 166 do referido código.

A solução com base na aplicação da teoria do abuso de direito, portanto, permitiria respeitar o campo de aplicação das disposições especiais que, inseridas no CDC, são aplicáveis unicamente em favor dos consumidores, evitando, ao mesmo tempo, o aniquilamento de toda e qualquer proteção aos profissionais que não estejam sob o manto de um contrato de adesão contra as cláusulas abusivas (uma vez que este é um dos requisitos do art. 424 do Código Civil, conforme será abordado mais adiante).

Cláudia lima MARQues, porém, entende não ser possível aplicar o conceito de abuso de direito do art. 187 do Código Civil como base conceitual do art. 51 do CDC, que trata das cláusulas abusivas. Segundo a autora, a idéia de abuso de direito do CDC seria mais ampla, no que tange à matéria, e mais específica, no tocante à vulnerabilidade do cocontratante $^{309}$.

Ademais, vale lembrar que a presença de cláusulas abusivas não é o único motivo de equiparação de empresários a consumidores e o campo de incidência da teoria do abuso de direito não é exatamente o mesmo daquele em que se verifica um abuso de dependência

\footnotetext{
${ }^{308}$ Cf. DUBOUIS, Louis. La théorie de l'abus de droit et la jurisprudence administrative. Thèse pour le doctorat présentée a la Université de Poitiers, 1960. p. 229-235 e 258.

${ }^{309}$ Cf. MARQUES, Cláudia Lima. Diálogo entre o Código de Defesa do Consumidor e o novo Código Civil: do "diálogo das fontes" no combate às cláusulas abusivas, cit., p. 96.
} 
econômica, como se viu. Assim, mesmo que não se considere a aplicação da teoria do abuso de direito, haveria ainda uma última chance aos profissionais sujeitos a abusos cometidos por seus contratantes em posição de superioridade: a equiparação a consumidor.

Nota-se, portanto, que os empresários sujeitos a uma situação de abuso de dependência econômica poderiam se valer de inúmeros institutos, como os novos princípios sociais introduzidos pelo Código Civil de 2002, a revisão ou resolução por onerosidade excessiva, a lesão ou o abuso de direito. Todos esses institutos, porém, dependem de uma análise do caso concreto e estão sujeitos a termos vagos e subjetivos. Assim, muito embora tais institutos, em tese, devessem ser suficientes para o resguardo dos abusos cometidos no âmbito dos contratos interempresariais, é possível que, na prática, eles não sejam suficientes para a tutela necessária, seja por uma aplicação deficiente por parte do magistrado, seja ainda por uma questão de dificuldade de se produzirem as provas necessárias em juízo.

\subsubsection{Insuficiência das normas do direito antitruste}

Muitos dos abusos praticados pelo contratante em posição de superioridade podem ser também sancionados pelo direito antitruste.

O direito antitruste tem por objetivo garantir a concorrência de forma leal, preservar o fluxo de informações no mercado para o consumidor, garantir o equilíbrio das relações econômicas e, finalmente, disciplinar as posições de poder econômico já estabelecidas e repreender eventuais abusos ${ }^{310}$.

Muito se pergunta se a Lei Antitruste brasileira (Lei 8.884/94) seria uma "lei de tutela da livre concorrência" ou uma "lei de repressão ao abuso do poder econômico". A resposta pode ser dada pela própria lei. Se fosse uma "lei de tutela da livre concorrência", a lei brasileira colocaria a livre concorrência ou livre iniciativa como bem maior a ser perseguido. Todavia, é possível notar pela legislação brasileira que algumas práticas, ainda que não prejudiciais à livre concorrência, são vedadas, como se verifica com a repressão aos lucros arbitrários, conforme se verá a seguir ${ }^{311}$.

\footnotetext{
${ }^{310}$ Cf. SALOMÃO FILHO, Calixto. op. cit., p. 55-57.

${ }^{311}$ Cf. FORGIONI, Paula Andréa. Os fundamentos do antitruste, cit., p. 225-226.
} 
O direito concorrencial brasileiro filia-se ao princípio da razoabilidade, não sendo admissível a ilegalidade per se em sede concorrencial ${ }^{312}$. Quer isto dizer que os comportamentos serão sempre analisados tendo em vista seus benefícios pró-competitivos e os aumentos da eficiência na atividade econômica. Como bem aponta TAUFICK, é essencial ter em mente que a concorrência não é um bem em si mesmo, haja vista que a ausência de concorrência, muitas vezes, é até mesmo necessária para o funcionamento eficiente de determinada atividade econômica ${ }^{313}$.

PAULA FORGIONI leciona que a "regra da razão" representa uma das principais válvulas de escape do processo interpretativo da legislação antitruste, deixando uma margem para que determinadas condutas restritivas da concorrência possam ser realizadas $^{314}$.

Tal regra, que teve origem no direito norte-americano (rule of reason), não foi prevista inicialmente no Sherman Act, sendo decorrência de uma criação jurisprudencial. Com o tempo, os juízes norte-americanos passaram a perceber que a aplicação literal do Sherman Act implicaria a condenação de inúmeras práticas capazes de produzir muito mais vantagens à economia nacional e aos consumidores do que prejuízos ao mercado. Dessa forma, foi instituída uma válvule de escape ao Sherman Act, pela qual somente as práticas que restringissem a concorrência de forma não razoável seriam consideradas ilegais, o que acabaria por ajudar a produzir o economic welfare, nas palavras de BORK ${ }^{315}$. O marco desse critério de razoabilidade foi o processo Standard Oil Co. of New Jersey v. United States, em $1911^{316}$.

No Brasil, a Lei 8.884/94 introduziu como principal válvula de escape da rigidez das regras concorrenciais o sistema das autorizações, pelo qual o CADE exerce um controle a posteriori das práticas realizadas no mercado ${ }^{317}$, autorizando-as ou não, a depender de seus elementos, mas também a "regra da razão" acabou, de certa forma, sendo introduzida no ordenamento pátrio.

\footnotetext{
${ }^{312}$ Pela regra de ilicitude per se, o operador do direito só faz a subsunção do fato à norma, sem efetuar uma análise dos elementos de mercado que cercam a conduta e das conseqüências que ela produz. Já pela "regra da razão", há uma maior flexibilidade da norma em relação aos fatos concretos, uma vez que o aplicador do direito leva em conta também os elementos que cercam a conduta.

${ }^{313}$ TAUFICK, Roberto Domingos. Cartel, ilegalidade per se e ônus da prova: breves considerações. Revista de Economia, Curitiba, ano 31, v. 33, n. 1, p. 151, 2007.

${ }^{314} \mathrm{Cf}$. FORGIONI, Paula Andréa. Os fundamentos do antitruste, cit., p. 180-181.

${ }^{315}$ Cf. Id. Ibid., p. 181-186.

${ }^{316}$ Cf. SHIEBER, Benjamin M. op. cit., p. 75.

${ }^{317}$ Cf. FORGIONI, Paula Andréa. Os fundamentos do antitruste, cit., p. 193-194.
} 
Em termos práticos, a Lei 8.884/94 exemplificou em seu art. 21 algumas condutas que seriam ilícitas, mas condicionou a ilicitude de tais comportamentos à verificação de uma das hipóteses previstas no art. 20 da mesma lei (fórmulas gerais dos três tipos de ilícitos concorrenciais).

$\mathrm{O}$ art. 21, dessa forma, traz um rol exemplificativo das hipóteses em que os ilícitos do art. 20 podem se verificar ${ }^{318}$. Dentre as condutas ali descritas, é possivel citar as dos incisos $\mathrm{XI}^{319}, \mathrm{XIV}^{320}, \mathrm{XXIII}^{321}, \mathrm{XXIV}^{322}$, que são também hipóteses bastante comuns de abuso de dependência econômica no âmbito contratual. A tutela do contratante mais fraco, portanto, acaba sendo possível muitas vezes tanto na seara privatística, quanto no âmbito concorrencial. Daí porque muitos autores defendem que a aplicação do CDC aos contratos interempresariais não deveria ser nunca permitida, uma vez que ao empresário já existiriam as regras protetivas do Código Civil e do direito antitruste. Como o art. 21 é meramente exemplificativo, ademais, quaisquer das hipóteses de abuso de dependência econômica poderiam ser tuteladas pelo direito concorrencial, ainda que a situação em concreto não estivesse prevista inicialmente na Lei 8.884/94.

A lógica do direito antitruste, contudo, é bastante distinta da lógica do direito civil ou consumerista, de modo que a necessidade de verificação da razoabilidade no caso concreto poderá inviabilizar, em algumas situações, uma tutela eficiente do empresário sujeito a um abuso por parte do contratante mais forte. Tal ocorre porque aquelas condutas descritas no art. 21 da referida lei somente configurarão infração da ordem econômica se

\footnotetext{
${ }^{318}$ Parte da doutrina defende que o rol trazido pelo art. 21 não poderia ser meramente exemplificativo, já que referidas normas têm natureza penal e, portanto, deveriam apresentar uma tipicidade estrita. Os argumentos que se contrapõem a essa corrente seguem a linha de que as normas do art. 21 são de cunho administrativo e, ainda que se aceitasse o caráter penal de suas normas, não haveria razão para não aceitar que o art. 20 apresentasse a definição dos ilícitos e o art. 21 apenas exemplificasse os ilícitos taxativamente descritos no art. 20. O legislador de 1994 tentou, com isso, encontrar uma via intermediária entre a regra per se, considerada exageramente rígida, e a regra da razão, pouco adaptável ao "formalismo civilista". A fórmula utilizada com a interligação dos arts. 20 e 21 da lei tiveram por objetivo dar liberdade ao juiz na formulação da regra da razão, dentro dos limites estabelecidos pelos princípios desenhados no art. 20, dificultar a contestação constitucional da tipologia aberta criada, por meio da criação dos princípios gerais do art. 20, e fornecer aos agentes econômicos certo grau de segurança jurídica por meio de uma lista, ainda que não fechada, das condutas puníveis (Cf. SALOMÃO FILHO, Calixto. op. cit., p. 101-102).

319“'Art. 21, XI-impor, no comércio de bens ou serviços, a distribuidores, varejistas e representantes, preços de revenda, descontos, condições de pagamento, quantidades mínimas ou máximas, margem de lucro ou quaisquer outras condições de comercialização relativos a negócios destes com terceiros".

320“Art. 21, XIV - dificultar ou romper a continuidade ou desenvolvimento de relações comerciais de prazo indeterminado em razão de recusa da outra parte em submeter-se a cláusulas e condições comerciais injustificáveis ou anticoncorrenciais".

321،Art. 21, XXIII - subordinar a venda de um bem à aquisição de outro ou à utilização de um serviço, ou subordinar a prestação de um serviço à utilização de outro ou à aquisição de um bem".

322“"Art. 21, XXIV-impor preços excessivos, ou aumentar sem justa causa o preço de bem ou serviço".
} 
implicarem ou puderem implicar a eliminação da concorrência, o domínio do mercado ${ }^{323}$ ou o aumento arbitrário de lucros ${ }^{324}$.

Uma mesma prática, portanto, pode configurar ou não concorrência ilícita dependendo do efeito que gera ou pode gerar ${ }^{325}$. A efetiva obtenção do efeito, todavia, é irrelevante para a caracterização da infração, bastando que haja elevada probabilidade de obtenção de um desses efeitos. Não obstante, a comprovação da intenção do agente em gerar efeitos anticoncorrenciais, na prática, é muito difícil. Em primeiro lugar, porque, em geral, não existem documentos internos comprobatórios das intenções do agente econômico e, em segundo, porque, ainda que existam tais documentos, eles só podem representar verdadeira intenção na medida em que haja uma capacidade mínima de produção dos efeitos desejados ${ }^{326}$.

Segundo a maior parte da doutrina nacional, dois requisitos básicos compõem a "regra da razão": o poder no mercado e a inexistência de justificativa para a conduta em questão $^{327}$. Algumas situações podem justificar, por exemplo, que o agente econômico cobre um preço elevado. Por outro lado, se o mercado for competitivo, ou seja, se o agente não tiver poder no mercado, e começar a cobrar um alto preço, a consequência disso será a perda de mercado por parte desse vendedor ${ }^{328}$.

De fato, a repressão à maioria das hipóteses do art. 21 só faz sentido se realmente estas estiverem identificadas com um dos ilícitos do art. 20. Todavia, isso não é necessariamente verdade. Tome-se como exemplo a imposição de quantidades mínimas ou máximas em um contrato entre empresários. A prática de tal ato, ainda que não caracterize um dos ilícitos do art. 20, pode trazer sérias consequências para um agente econômico em questão, sem prejudicar a concorrência de um modo geral, contudo.

\footnotetext{
${ }^{323}$ Os incisos II e IV do referido art. 20 remetem à noção de abuso de posição dominante, caracterizando, portanto, o ilítico de dominação do mercado. Para tal caracterização, portanto, é extremamente relevante: (i) a delimitação do mercado relevante e (ii) a constatação de posição dominante, sendo presumida esta, nos termos do $\$ 2^{\circ}$ desse mesmo artigo, quando a empresa ou grupo de empresas controlar $20 \%$ do mercado relevante (Cf. MUSSI, Luiz Daniel Rodrigues Haj. op. cit., p. 172-174 e 189-190).

${ }^{324}$ Uma crítica que se faz ao sistema estabelecido pela Lei $\mathrm{n}^{\circ}$. 8.884/94 é que, da forma como o art. 21 da lei está redigido, é possível chegar à conclussão de que todas as hipóteses do art. 21 poderiam caracterizar quaisquer dos ilícitos do art. 20, sendo que isso não é verdade. Os incisos XX e XXI, por exemplo, só fazem sentido se caracterizarem abuso de poder econômico, e não os demais ilícitos do art. 20. (Cf. SALOMÃO FILHO, Calixto. op. cit., p. 102-103).

${ }^{325} \mathrm{Cf}$. COELHO, Fabio Ulhoa. Curso de direito comercial. 8. ed. rev. e atual. São Paulo: Saraiva, 2004. v. 1, p. 209.

${ }^{326}$ Cf. SALOMÃO FILHO, Calixto. op. cit., p. 96-97.

${ }^{327}$ Esses dois requisitos, contudo, deveriam ser vistos com parcimônia na análise das condutas concorrenciais e, em especial, no caso das formas de dependência econômica relativa, segundo a classificação de CALIXTO.

${ }^{328}$ Cf. SALOMÃO FILHO, Calixto. op. cit., p. 91.
} 
Certo é que muitas práticas, se não prejudicam a concorrência como um todo, uma vez que podem ser praticadas no âmbito de uma relação contratual específica, pela qual um dos contratantes acabou se tornando dependente do outro, muitas vezes têm por objetivo o aumento arbitrário dos lucros por parte de quem as pratica. Portanto, tais condutas também deveriam ser reprimidas pelo direito concorrencial, já que o inciso III do art. 20 não faz qualquer referência a eventual posição dominante eventualmente detida pelo agente econômico que as pratica. No caso acima exemplificado, contudo, é possível se vislumbrar uma situação em que a concorrência como um todo não é prejudicada e, possivelmente, a intenção do contratante em posição de superioridade não é obter lucros exorbitantes, mas apenas se precaver de um risco do negócio (transferir para o parceiro comercial o risco da oferta versus demanda).

Cabe notar que a repressão aos lucros arbitrários, de um modo geral, não traz qualquer incentivo à concorrência ou à livre iniciativa, visando, precipuamente, à proteção dos consumidores. Trata-se do único aspecto da Lei 8.884/94 em que o interesse dos consumidores é protegido de forma imediata. Todavia, em algumas situações o aumento arbitrário dos lucros pode também configurar um atentado à concorrência e à livre iniciativa. É o caso, por exemplo, do franqueador que aufere lucros excessivos pela imposição de cláusulas restritivas da concorrência a seus franqueados ${ }^{329}$.

A intenção de gerar um dos efeitos do art. 20 por parte do agente econômico que pratica uma das condutas descritas no art. 21 pode ser muitas vezes presumida (caracterizando-se pela inexistência de outra justificativa para o ato e por requisitos estruturais que permitam inferir que a atuação poderá atingir seus objetivos ${ }^{330}$ ), mas especificamente em relação à dependência empresarial, segundo a classificação anteriormente analisada de CALIXTO, isso não necessariamente é verdade. Tal ocorre, em especial, nas formas de dependência absoluta e, em alguns casos, nas demais formas de dependência relativa.

Conclui-se, com isso, que a regra da razão é um excelente mecanismo para a repressão de condutas abusivas em âmbito concorrencial, mas não necessariamente para corrigir os abusos e desvios surgidos em uma relação contratual específica. Para tanto, existiriam os remédios contratuais, que, como visto, no caso do Código Civil, também podem não ser suficientemente eficazes para tutelar todas as relações interempresariais.

\footnotetext{
${ }^{329}$ Cf. FORGIONI, Paula Andréa. Os fundamentos do antitruste, cit., p. 235-239.

${ }^{330}$ Cf. SALOMÃO FILHO, Calixto. op. cit., p. 213.
} 
Vale apontar, ainda, que, muito embora a tendência em direito antitruste seja um deslocamento do controle das estruturas para o controle dos comportamentos, a atenção das autoridades encarregadas da aplicação do controle das condutas tem sido escassa até o momento $^{331}$. A repressão aos comportamentos estratégicos, por exemplo, tem ficado restrita à questão dos preços predatórios e das inovações tecnológicas tendentes à eliminação de concorrentes ${ }^{332}$.

Tal decorre da própria origem do direito antitruste no Brasil. Em razão da formação do sistema econômico desde os tempos de colônia em torno de monopólios (estatais e privados), existe na Constituição e na lei antitruste brasileira uma clara opção em favor de um direito concorrencial de inspiração institucional, orientado exatamente a propor um verdadeiro código de conduta ao monopolista. O legislador pátrio, tendo em conta a realidade nacional de excessiva concentração, optou por coibir, assim, os abusos daqueles que detêm posição de dominação ${ }^{333}$. Exatamente por essa razão que a atual Constituição da República brasileira tem como ilícito concorrencial central o abuso de poder econômico (artigo $173, \S 4^{\circ} \mathrm{CF}$ ). O controle dos comportamentos em sede concorrencial, que poderiam prejudicar apenas um ou alguns agentes econômicos, sem representar um prejuízo institucional à concorrência, portanto, acabou sendo deixado um pouco de lado.

Ademais, não obstante a teorização econômica do direito antitruste baseie-se na proteção do consumidor, não há como comparar a tutela desse sujeito do mercado pelo direito próprio do consumidor com sua tutela pelo direito concorrencial. Como bem apontou CALIXTO:

\begin{abstract}
“(...) o fato de o consumidor ser o destinatário econômico final das normas concorrenciais não o transforma em destinatário jurídico direto das mencionadas normas. Muitas vezes é apenas através da proteção da 'instituição' concorrência que seu interesse será protegido",334.
\end{abstract}

O consumidor, portanto, é protegido, em geral, de forma reflexa pelo direito concorrencial, e não como destinatário direto de suas normas ${ }^{335}$. Sem contar que, no direito

\footnotetext{
${ }^{331}$ Cf. SALOMÃO FILHO, Calixto. op. cit., p. 18 e 23.

${ }^{332} \mathrm{Cf}$. Id. Ibid., p. 34.

${ }^{333} \mathrm{Cf}$. Id. Contrato de "franchising" e ilícito concorrencial. In: pareceres. São Paulo: Malheiros Ed., 2002. p. 117-118.

${ }^{334}$ Id. Direito concorrencial: as condutas, cit., p. 81 .

${ }^{335} \mathrm{~A}$ proteção reflexa do consumidor pelo direito concorrencial se verifica, conforme aponta EUGENE BUTTIGIEG, na medida em que "competition policy seeks to achieve a market that is as fully competitive and economically efficient as possible where competitors compete for custom by providing the lowest prices, the best quality products and services, the latest technology and the widest choice - and all this is to
} 
da concorrência, não há propriamente a proteção do interesse direto e individual, como ocorre no direito consumerista, mas sim um controle institucional da concorrência, que é protegido pelas vias administrativas (por meio da Secretaria de Direito Econômico do Ministério da Justiça - SDE e do Conselho Administrativo de Defesa Econômica CADE). Embora a lei concorrencial brasileira autorize expressamente o ajuizamento de uma demanda visando à proteção de direitos individuais ou individuais homogêneos com base em fundamentos concorrenciais, conforme se verifica de seu art. $29^{336}$, tal defesa se dará no campo privatístico, por meio de uma ação civil comum de conhecimento, e demandará a comprovação de todos os requisitos exigidos pelo direito antitruste, uma vez que o fundamento da ação será concorrencial ${ }^{337}$.

Sem contar que a atuação do CADE no controle das práticas realizadas no mercado se dá a posteriori. Em razão disso, tais práticas acabam por produzir efeitos plenos até serem formamelmente proibidas pela autoridade antitruste ${ }^{338}$.

A plena proteção do consumidor se dá pela aplicação complementar do direito concorrencial e do direito consumerista ${ }^{339}$, mas essa complementariedade se verifica mais fortemente nos países em que a mesma autoridade é responsável pela aplicação dos normativos de ambos os microssistemas, tal como ocorre nos Estados Unidos, Inglaterra e Itália. Alguns países, como a Suécia, inclusive, já tratam num único corpo de normas a proteção de todos os agentes do mercado, sejam eles produtores, distribuidores ou consumidores. Tem se verificado em muitos países uma tendência no sentido de passar a

the benefit of consumers". O próprio autor, contudo, adverte que o direito antitruste não é suficiente para resguardar os interesses dos consumidores, já que de nada adianta ter os melhores preços no mercado, por exemplo, se os produtos não forem seguros e puderem machucar os consumidores, assim como de nada adianta aos consumidores ter uma ampla variedade de produtos e serviços se eles não puderem fazer a escolha adequada por falta de informação ou em decorrência de uma propaganda enganosa. $\mathrm{O}$ direito antitruste, embora proteja reflexamente os interesses dos consumidores, não é suficiente para resguardá-los das falhas e imperfeições de mercado, tampouco das práticas ou cláusulas abusivas que venham a ser impostas pelo forneceder (BUTTIGIEG, Eugene. Consumer and competition policies: synergy needed. Consumer Policy Review, v. 15, n. 5, p. 192-193, Sep./Oct. 2005).

336“"Art. 29. Os prejudicados, por si ou pelos legitimados do artigo 82 da Lei $n^{\circ} 8.078$, de 11 de setembro de 1990, poderão ingressar em juízo para, em defesa de seus interesses individuais ou individuais homogêneos, obter a cessação de práticas que constituam infração da ordem econômica, bem como o recebimento de indenização por perdas e danos sofridos, independentemente do processo administrativo, que não será suspenso em virtude do ajuizamento da ação".

${ }^{337}$ Cf. SALOMÃO FILHO, Calixto. Contrato de "franchising" e ilícito concorrencial, cit., p. 136.

${ }^{338}$ FORGIONI, Paula Andréa. Os fundamentos do antitruste, cit., p. 193-194.

${ }^{339}$ A simbiose desses dois ramos do direito faz com que eles sejam agrupados, no direito francês, sob uma denominação comum: "droit du marché". Se a finalidade imediata de ambos é diferente - lealdade e liberdade da concorrência, de um lado, e proteção dos consumidores, de outro - há de se reconhecer que os dois microssistemas possuem por finalidade mediata o bom funcionamento do mercado (Cf. PICOD, Yves. Droit du marché et droit commun des obligations - Rapport introductif. RTD Com., v. 51, n. 1, p. 2, janv./mars 1998). 
tratar os interesses dos consumidores como plano principal da política antitruste ${ }^{340}$, mas, enquanto isso não se materializar no Brasil, a tutela do contratante em posição de inferioridade por tal microssistema não terá a mesma eficácia que a tutela pelo CDC.

Em resumo, é possível entender que a comprovação de um prejuízo, ainda que potencial, à concorrência ou de aumento arbitrário de lucros - como exige a regra da razão - é muitas vezes difícil e demorada. O controle de uma situação de abuso por parte do contratante em posição de superioridade por meio de instrumentos de contornos estritamente privatísticos, como seria o controle pelo CDC, não demandaria a ocorrência de um efeito restritivo sobre a concorrência ou a comprovação do aumento arbitrário de lucros (ou ao menos sua intenção), ao contrário do que exige a "regra da razão" no direito concorrencial. A tutela do contratante mais fraco pelo CDC, portanto, seria mais simples e célere.

\subsubsection{Aplicação das normas do CDC aos contratos interempresariais: desvirtuamento da lógica do sistema?}

Conforme explanado nas linhas acima, o CDC tem por objetivo tratar de modo especial um grupo de pessoas também especial, vulnerável. Assim, a utilização desse código de forma desordenada e sem uma justificativa plausível, acabaria por tornar o microssistema consumerista em direito comum, não havendo mais um tratamento diferenciado para aqueles sujeitos em posição desprivilegiada. Ademais, a utilização do referido diploma legal em prol de pessoas jurídicas não pode ter por objetivo eliminar o risco do sistema, visto que este é inerente à atividade empresarial.

A unificação do direito comercial e do direito civil em um único código, bem como a corporificação das normas de consumo em apenas um diploma ${ }^{341}$, por outro lado, acabaram por dificultar a identificação da disciplina a ser aplicada no caso concreto, tendo surgido zonas cinzentas que estão aptas a receber o regramento tanto de um quanto de outro código. Isso, conjugado com o aumento da complexidade das relações jurídicas e o surgimento de formas massificadas de contratação, levou o aplicador do direito a buscar alternativas no ordenamento para os abusos que viessem a surgir.

\footnotetext{
${ }^{340}$ BUTTIGIEG, Eugene. op. cit., p. 193.

${ }^{341}$ Cf. STAGNI, Alexandre; NOGUEIRA, André Coutinho; CABELEIRA, Caio; OUCHANA, Elber Christian; GOMES, Guilherme Amado. op. cit., p. 239.
} 
Passou-se a defender, então, uma ampliação da base de atuação do CDC, com vistas a permitir sua utilização em contratos celebrados entre duas empresas. O que poderia, num primeiro momento, parecer uma afronta ao direito empresarial, por aviltar sua lógica e preterir a aplicação do direito comum na relação entre "iguais", em favor do CDC, na verdade não o $\mathrm{e}^{342}$.

Em primeiro lugar, como aponta KARAM-SILVEIRA, a classificação de relações entre "iguais" no Código Civil e entre "desiguais" no CDC não é a mais adequada, pois a desigualdade está sempre presente, inclusive nas relações entre civis, ainda que em grau menor. A diferença é que nas relações de consumo ela é presumida e, em geral, mais acentuada $^{343}$.

Em segundo, porque não foi o intuito do legislador, tampouco deve ser o do aplicador do direito, substituir o direito comum pelo CDC, mas somente preencher certas lacunas que ainda não eram muito bem reguladas, tal qual ocorria com os contratos de adesão $^{344}$. Trata-se de dois sistemas com uma racionalidade distinta e, ainda que, atualmente, possuam muitos princípios em comum, os critérios e limites para a efetiva utilização de tais em muitos casos diferem.

O CDC atua em uma dimensão diferente da que o direito empresarial trabalha. A este é mais relevante agir no sentido de padronizar comportamentos (boa-fé objetiva) para, assim, aumentar a previsibilidade, a segurança e a confiança das relações, impedindo apenas abusos dos agentes econômicos (monopólios, cartéis etc.). Não se preocupa, de maneira prioritária, com o amparo do agente mais fraco. Já o direito consumerista busca primordialmente o amparo da parte hipossuficiente, não tendo como objetivo regular as relações empresariais como um todo ${ }^{345}$.

O fato de os princípios que integram o CDC, como a boa-fé objetiva e a função social dos contratos, serem os mesmos contemplados atualmente pelo direito comum de certa forma até facilita o diálogo entre esses dois campos, de modo que a influência do

\footnotetext{
${ }^{342}$ Cf. STAGNI, Alexandre; NOGUEIRA, André Coutinho; CABELEIRA, Caio; OUCHANA, Elber Christian; GOMES, Guilherme Amado. op. cit., p. 240.

${ }^{343}$ Cf. KARAM-SILVEIRA, Marco Antonio. op. cit., p. 500.

${ }^{344}$ Cf. STAGNI, Alexandre; NOGUEIRA, André Coutinho; CABELEIRA, Caio; OUCHANA, Elber Christian; GOMES, Guilherme Amado. op. cit., p. 241.

${ }^{345}$ Cf. Id. Ibid., p. 242.
} 
CDC nas relações interempresariais não chega a aviltar a lógica do direito empresarial e introduzir uma nova ${ }^{346}$.

Finalmente, como bem apontado por parte da doutrina nacional, a utilização das normas do CDC em contratos celebrados entre duas empresas não é feita arbitrariamente, de modo a colocar em desuso as normas e princípios do direito empresarial. Há critérios para a sua aplicação, como, por exemplo, a necessidade de comprovação da vulnerabilidade de um dos contratantes, não sendo justificável a tutela do CDC numa relação na qual se constate apenas mera fragilidade de uma das partes ${ }^{347}$. Uma grande empresa oligopolista, por exemplo, não pode se valer do CDC da mesma forma que um microempresário $^{348}$.

Em meio ao aumento da complexidade das relações e à nova realidade social e econômica, a aplicação do CDC aos contratos interempresariais em alguns casos excepcionais tem por fim apenas e tão somente suprir eventuais deficiências do direito comum na correção dos desequilíbrios e abusos gerados, prestigiando o próprio fluxo econômico e o desenvolvimento do direito empresarial.

Cláudia lima Marques, embora defenda que, com a edição do Código Civil de 2002, não mais exista utilidade na aplicação do CDC às relações entre empresários ${ }^{349}$, ao tratar de uma das formas de diálogo das fontes, conforme exposto no item 3.3.3 do presente estudo, não descarta a possibilidade de aplicação do diploma consumerista aos contratos interempresariais em casos excepcionais, conforme se depreende do trecho a seguir:

\footnotetext{
${ }^{346}$ CLÁUDIA LIMA MARQUES lembra que "a convergência de princípios e cláusulas gerais entre o CDC e o NCC/2002 e a égide da Constituição Federal de 1988 garantem que haverá diálogo e não retrocesso na proteção dos mais fracos nas relações contratuais" (MARQUES, Cláudia Lima. Diálogo entre o Código de Defesa do Consumidor e o novo Código Civil: do "diálogo das fontes" no combate às cláusulas abusivas, cit., p. 99).

${ }^{347}$ Cf. STAGNI, Alexandre; NOGUEIRA, André Coutinho; CABELEIRA, Caio; OUCHANA, Elber Christian; GOMES, Guilherme Amado. op. cit., p. 240-242.

${ }^{348}$ Cf. LOPES, José Reinaldo de Lima. Responsabilidade civil do fabricante e a defesa do consumidor. São Paulo: Ed. Revista dos Tribunais, 1992. p. 78-79.

${ }^{349}$ Segundo CLÁUdIA LIMA MARQUES, "a entrada em vigor do NCC/2002 com normas voltadas justamente para regular com boa-fé e conforme a função social destes contratos as relações inter-empresários levará a uma necessária redefinição do campo de aplicação do CDC, a beneficiar a teoria finalista uma adaptação do sistema ao diálogo destas duas leis. O NCC/2002 deve ter efeito útil (effet utile), logo, deve ter algum campo de aplicação privilegiado e este é o dos contratos inter-empresariais, que não mais necessitam ser regulados pelo CDC (seja pela interpretação maximalista do art. $2^{\circ}$ do CDC, seja pela expansão protetiva do art. 29 do CDC a todos os contratos de adesão). Os contratos inter-empresariais não mais necessitam ser regulados pelo CDC, pois o NCC/2002 traz os mesmos princípios protetores (boafé objetiva, onerosidade excessiva, lesão etc.) e ainda normas específicas para regular as relações entre iguais" (MARQUES, Cláudia Lima. Diálogo entre o Código de Defesa do Consumidor e o novo Código Civil: do "diálogo das fontes" no combate às cláusulas abusivas, cit., p. 92).
} 
"Tratando-se de lei especial de consumo visualizo este diálogo de influência recíproca excepcional como sendo possivel em relações civis puras, envolvendo pessoa ou contratantes mais fracos e mais raramente nas relacõos entre profissionais ou empresários" (grifos nossos) ${ }^{350}$.

Há de se esclarecer, porém, que certa parte da doutrina é bastante receosa com a “consumerização" dos contratos celebrados em âmbito empresarial ${ }^{351}$. PAULA FORGIONI, por exemplo, adverte que, pela peculiaridade dos contratos interempresariais, que obedecem a uma lógica diversa daqueles civis, uma aplicação distorcida de textos normativos e princípios de abrangência geral (ou mesmo de inspiração consumerista) a esses contratos poderá dificultar a concretização da função econômica deles esperada ${ }^{352}$.

Entende a autora que há uma tendência no Brasil de se confundirem as áreas de incidência de diplomas diversos, como é o caso do CDC e da Lei Antitruste, confusão que decorre do fato de que os bens jurídicos mediatamente tutelados por uma lei são protegidos de forma direta e imediata pela outra. A aplicação técnica de tais diplomas, contudo, deve ser apartada, sob pena de se comprometer a aplicação eficaz de ambos ${ }^{353}$.

Todavia, urge salientar que, como a própria autora previne, existem empresários que desfrutam de uma situação econômica vantajosa em relação ao outro e são capazes de impor sua vontade, o contrato e as respectivas condições, dominando o jogo da contratação e utilizando-o a seu exclusivo favor, em detrimento da parte contrária. Exatamente por essa razão que se impõe um sistema de tutela eficiente para o contratante mais fraco, que parte da legislação antitruste, da repressão ao abuso de dependência econômica e da concorrência desleal ${ }^{354}$.

Ocorre que, muitas vezes, os instrumentos legais já existentes para a proteção do contratante mais fraco não são suficientes para impedir o abuso por parte do contratante

\footnotetext{
${ }^{350}$ Cf. MARQUES, Cláudia Lima. Diálogo entre o Código de Defesa do Consumidor e o novo Código Civil: do "diálogo das fontes" no combate às cláusulas abusivas, cit., p. 95.

${ }^{351} \mathrm{Um}$ dos argumentos mais fortes daqueles que são contrários à consumerização dos contratos interempresariais parte do próprio conceito de empresário, que, nos termos do artigo 966 do atual Código Civil brasileiro, envolve a noção de profissionalismo, o que exclui em absoluto a idéia de hipossuficiência. Ocorre que, ainda que profissionais, nem todos os empresários têm a mesma força econômica, até porque, para que sejam empresários, em algum momento se verificou o início desse profissionalismo, que não pode ser comparado ao profissionalismo de um agente econômico que já esteja no mercado há bastante tempo. Em alguns casos, ainda, cabe ressaltar que o contrato é celebrado entre uma grande empresa, detentora de uma marca famosa, por exemplo, e um empresário individual (pessoa física).

${ }^{352}$ Cf. FORGIONI, Paula Andréa. A interpretação dos negócios empresariais no novo Código Civil brasileiro, cit., p. 7-38.

${ }^{353} \mathrm{Cf}$. Id. Os fundamentos do antitruste, cit., p. 239-240.

${ }^{354} \mathrm{Cf}$. Id. A interpretação dos negócios empresariais no novo Código Civil brasileiro, cit., p. 10-11.
} 
mais forte, como visto acima. Daí porque forçoso concluir que não há razão para se negar a aplicação de outro sistema já existente - o consumerista - a esses casos limítrofes e sem respaldo legal.

Sem contar que atribuir uma análise exclusivamente econômica ao Direito, adotando-se princípios da microeconomia e critérios pragmáticos, típicos de orientações utilitaristas, acaba por minar uma das principais razões de ser dessa ciência, que é a difusão do conceito de justiça, tendo por norte também o sentido humano ${ }^{355}$. Isso não quer dizer que as noções da ciência econômica devam ser desprezadas pelo Direito, mas apenas que os elementos de tal ciência devem ser utilizados como suporte para os conceitos jurídicos, os quais serão também balizados por outros elementos, advindos, por exemplo, da ciência social. Isso justifica, por exemplo, a utilização, aqui pretendida, da noção de dependência econômica também no âmbito contratual.

Como bem afirmou TEPEDINO, o CDC tem uma "vocação expansionista", isto é, influencia o direito civil como um todo, uma vez que seus princípios expressam valores constitucionais. Tal vocação leva à extensão dos mecanismos de proteção a todo e qualquer contrato em que se verifique um análogo desequilíbrio de forças entre os contratantes. Para o autor, a aplicação do CDC mesmo quando não houver propriamente uma relação de consumo, desde que os pressupostos da hipossuficiência sejam identificados no caso concreto, é tranquila ${ }^{356}$.

O próprio Código Civil de 2002, que segundo muitos autores teria reduzido o campo de aplicação do CDC ao introduzir diversos princípios como a boa-fé objetiva, a função social dos contratos, a onerosidade excessiva, o abuso de direito, a lesão etc. nas relações entre profissionais, nem sempre é suficiente para conferir a tutela adequada aos casos de abuso de dependência econômica no âmbito interempresarial. Os dispositivos que tratam de tais conceitos, como visto ao longo do presente trabalho, ainda que se apliquem aos empresários, têm aplicação muito mais restrita do que os dispositivos do CDC, especialmente para o caso das pessoas jurídicas ${ }^{357}$.

\footnotetext{
${ }^{355}$ Cf. MÁRIO JÚlio DE Almeida COSTA apud NEGREIROS, Teresa. op. cit., p. 393-394, nota 612.

${ }^{356} \mathrm{Cf}$. TEPEDINO, Gustavo. As relações de consumo e a nova teoria contratual. In: Temas de direito civil. Rio de Janeiro: Renovar, 1999. p. 203, 211 e 212.

${ }^{357}$ RUY ROSADO aponta, por exemplo, que o conceito de lesão no CDC é puramente objetivo, exigindo-se somente a quebra de equivalência do contrato em razão de prestações exageradamente desiguais, independentemente das condições pessoais das partes ou circunstâncias do negócio. Já o Código Civil exige a comprovação do estado de necessidade ou da inexperiência da parte prejudicada (Cf. AGUIAR JR., Ruy Rosado de. Projeto de Código Civil: as obrigações e os contratos. Revista de Direito Renovar, Rio de Janeiro, n. 15, p. 26, 1999.
} 
Como bem aponta CláUdia Lima MARQues, a diferença de paradigma concedida pelos dois diplomas legais é substancial:

“(...) A proteção de desigual concedida pelo CDC é mais forte do que a boa-fé normal das relações entre iguais. (...) Desta forma, se há o paradigma da boa-fé nas relações entre iguais (dois empresários) e há o dever de informar, é claro que a informação entre experts deve ser mais branda, mesmo que leal, pois são dois profissionais e especialistas. Já a informação do expert em relação ao consumidor é um dever qualificado, há que se pressupor que ele é um leigo, há dever de esclarecer, aconselhar, explicar dados que seriam banais e pressupostos entre dois empresários, mas não entre um profissional e um leigo" ${ }^{358}$.

Não se nega, contudo, que a regra é a de que o CDC não se aplica aos contratos celebrados entre empresários $^{359}$, mas como diria o jargão popular, já que toda regra tem sua exceção, parece correto crer que, caracterizados os elementos da dependência econômica e verificada alguma forma de abuso em razão dessa situação de dependência, os dispositivos do diploma legal consumerista poderão ser aplicados aos contratos entre empresários, por meio da equiparação ao consumidor acima abordada, sempre que os institutos do Código Civil ou do direito antitruste não forem suficientes para sanar os abusos cometidos no caso concreto. Isso, porque, apesar da lógica dos contratos interempresariais ser diferente daquela aplicada aos contratos de consumo, quando houver argumentos para ambos os lados (se cabe a aplicação do CDC ou não), deve-se buscar adequar a aplicação da lei à realidade, a fim de se atingir a solução mais justa no caso concreto ${ }^{360}$.

\footnotetext{
${ }^{358}$ MARQUES, Cláudia Lima. Superação das antinomias pelo diálogo das fontes: o modelo brasileiro de coexistência entre o Código de Defesa do Consumidor e o Código Civil de 2002, cit., n. 51, p. 57.

${ }^{359}$ JUNQUEIRA DE AZEVEDO, defendendo uma eqüidistância na aplicação do Código Civil e do CDC, relembra que "o advento do CDC provocou, entre os civilistas, duas reações extremadas: de um lado, a dos mais tradicionalistas, que nada mais viram, na nova unidade normativa, que uma lei especial, destinada a um grupo de pessoas em situação peculiar, os consumidores; de outro, a dos operadores do direito que passaram a ver, no CDC, o código central do direito privado brasileiro, com importância muito superior ao velho Código Civil e a todo o direito civil construído pela doutrina e jurisprudência dos últimos cem anos. Embora o princípio aristotélico in médio virtus não seja de universal aplicação, acreditamos que, no caso, expressa ele uma verdade" (AZEVEDO, Antonio Junqueira de. Relação jurídica que não é de consumo. Destinatário final. Cláusula abusiva [Parecer]. In: Estudos e pareceres de direito privado, cit., p. 228).

${ }^{360}$ Sobre a coexistência do Código Civil e do CDC, o magistério de CláUdia LiMA MARQuES é muito elucidativo: "No Brasil de hoje, a construção de um Direito Privado com função social, proposta por JHERING e GIERKE, e o futuro da Justiça para os mais fracos nos Tribunais brasileiros ainda depende do grau de domínio que os aplicadores da lei conseguirem alcançar neste momento, sobre o sistema de coexistência do direito do consumidor, presente no CDC, e do direito civil e direito comercial das obrigações, presentes no CC/2002. A tarefa de especialização e de excelência, no uso das normas de direito do consumidor, renova-se. Quem, neste momento, for ingênuo e seguir as primeiras visões do CC/2002, repetindo os preceitos do direito civil "dos iguais” do século XIX ou do CC/1916, contribuirá para o fim do direito comercial e para um esvaziamento inconstitucional do direito do consumidor. Quem, ainda, for ingênuo e seguir os modelos do eruditamente colocados como definitivos de direito comparado,
} 


\subsection{Caracterização do empresário como consumidor: uma realidade possível no direito brasileiro?}

Como visto no início deste estudo, para os adeptos da Teoria Maximalista, que defendem um campo de aplicação amplo e abrangente para o CDC, a caracterização do empresário como consumidor, para fins de aplicação das normas mais benéficas do CDC aos contratos interempresariais, seria plenamente possível, sempre que o empresário estivesse sujeito a práticas abusivas.

Mesmo que se entenda correta a interpretação mais restritiva do art. 29, contudo, como propõem os simpatizantes da Teoria Finalista, ainda assim seria de se aplicar a alguns desses contratos a equiparação nele prevista, desde que comprovada a vulnerabilidade do empresário, segundo os critérios anteriormente analisados. Tal ocorre porque a tendência doutrinária e jurisprudencial dos finalistas - e que é também a defendida no presente estudo - é passar a aceitar a aplicação das normas do CDC aos contratos interempresariais sempre que for possível a comprovação da vulnerabilidade destes, ao que se deu o nome de Teoria Finalista Aprofundada.

Para o caso dos contratos de dependência econômica, porém, o debate pode se tornar inócuo. A uma, porque os contratos de dependência econômica são, em geral, contratos de adesão. A duas, porque as práticas comerciais abusivas impostas por alguns empresários a seus parceiros comerciais são muitas vezes evidentes. E, finalmente, porque, frente a seus parceiros privilegiados, os contratantes em posição de inferioridade, decorrente de um contrato de dependência econômica, são flagrantemente vulneráveis. E mesmo nos casos em que o contrato de dependência econômica não seja de adesão, os dois últimos argumentos já seriam suficientes para fazer incidir o art. 29 do CDC, sempre que verificada uma situação de abuso por parte do contratante mais forte.

Não é preciso muito para se convencer disso. Tome-se como exemplo o contrato de franquia, em que as empresas franqueadoras são, em geral, grandes empresas, detentoras de um poder econômico ao menos razoável, e com amplos conhecimentos no ramo, ao passo que os franqueados, muitas vezes, se encontram em sua primeira experiência 
empresarial, aventurando-se em um mercado sem conhecimento algum, ou ao menos limitado. Assim, torna-se muito fácil e até mesmo cômodo a alguns franqueadores explorar a inexperiência de seus franqueados ${ }^{361}$.

Um dos exemplos de prática abusiva prevista no CDC ao qual os empresários também estão usualmente sujeitos é a de que trata o inciso I do art. 39 desse Código, isto é, "condicionar o fornecimento de produto ou de serviço ao fornecimento de outro produto ou serviço, bem como, sem justa causa, a limites quantitativos". É exatamente o caso dos tie-ins ${ }^{362}$ e da imposição de quotas ${ }^{363}$ no contrato de franquia, muito comuns na prática empresarial.

Há, enfim, por parte de muitos empresários, em decorrência de motivos variados, uma verdadeira necessidade de contratar com determinada pessoa. Trata-se daquilo a que ClÁUDIA LIMA MARQUES denomina "vulnerabilidade fática”. Esta, conforme visto no item 3.1.4 deste trabalho, é aquela em que:

"o ponto de concentração é o outro parceiro contratual, o fornecedor que por sua posição de monopólio, fático ou jurídico, por seu grande poder econômico ou em razão da essencialidade do serviço, impõe sua superioridade a todos que com ele contratam (...."364.

A verdade é que em muitos contratos interempresariais a aplicação do CDC não é mesmo de espantar. Basta voltar os olhos ao art. $4^{\circ}$ do diploma consumerista, que estabelece a Política Nacional das Relações de Consumo, tendo como um de seus princípios a “(...) coibição e repressão eficientes de todos os abusos praticados no mercado de consumo (...) que possam causar prejuízos aos consumidores (...)" (inciso VI).

\footnotetext{
${ }^{361}$ Não se nega que quem está disposto a ingressar no meio empresarial deve se sujeitar aos riscos a ele inerentes, não podendo alegar, depois, falta de experiência empresarial. Todavia, sabe-se que isso, muitas vezes, ocorre na prática, sendo certo que tal situação não dá o direito ao contratante privilegiado de abusar do contratante em posição de inferioridade.

${ }^{362} \mathrm{~A}$ figura do tie-in ou tying arrengement, segundo definição dada pelo juiz do caso Northern Pacific Railway Company versus United States [Disponível em: $<$ http://caselaw.lp.findlaw.com/scripts/getcase.pl?court=us\&vol=408\&invol=811>. Acesso em: 12 jan. 2007], consiste num contrato em que uma das partes subordina a venda de um produto (tying product) à condição de que o comprador adquira também um segundo produto (tied product). Pode-se observar neste tipo de contrato, desse modo, duas prestações diversas: aquela que é desejada pelo contratante e uma outra que lhe é imposta pela parte contrária.

${ }^{363} \mathrm{~A}$ imposição de quotas diz respeito à obrigação de o parceiro mais fraco manter certo volume de negócios com seu parceiro privilegiado. Assim, independentemente da procura do bem ou produto pela clientela, o parceiro mais fraco é obrigado a comprar certa quantidade dele todo mês, correndo o risco de não conseguir escoar tudo o quanto foi adquirido.

${ }^{364}$ MARQUES, Cláudia Lima. Contratos no Código de Defesa do Consumidor, cit., 2002, p. 273.
} 
Ninguém há de negar que as relações jurídicas mantidas entre muitos empresários inserem-se no seio do mercado de consumo. Mais que isso, essas relações podem ser vistas até mesmo como relações de consumo por conexão ${ }^{365}$.

Importa notar, neste passo, que, em muitas relações empresárias, tal qual a que se verifica entre franqueadores e franqueados, por exemplo, diversas são as operações intermediárias e correlatas ao consumo em sentido estrito. E é justamente nos contratos que instrumentalizam essas operações intermediárias que se vislumbra a conexidade contratual.

Sobre o tema, o magistério de CLÁUdiA LIMA MARQUES apresenta-se bastante elucidativo. Entende a autora que a visão da conexidade contratual das operações intermediárias ao consumo complexo de produtos e serviços dos dias de hoje é uma necessidade patente. Conceitua os contratos conexos como aqueles cuja finalidade é justamente facilitar ou realizar o consumo. Assim, para ela, o aplicador do CDC deve estar sempre atento para o fenômeno da conexidade, pois uma visão real e socialmente útil da multiplicidade e complexidade das relações contratuais pós-modernas pode se opor a uma visão formalista e reduzida a impedir a realização da função social dos contratos ${ }^{366}$.

Não foi, então, à toa que o legislador do CDC incluiu no texto legal a possibilidade de equiparação cuja aplicação ora se está a discutir. Ciente da complexidade das relações travadas no mercado de consumo (algumas das quais merecedoras da proteção consumerista, mas a rigor fora de seu campo estrito de aplicação), criou-se instrumento útil - a equiparação do art. 29 - que, dentro de seus limites, presta-se à coibição de todos os abusos praticados no mercado de consumo, como pretende a Política Nacional das Relações de Consumo e seus princípios básicos.

\footnotetext{
${ }^{365}$ TOMASETTI, em parecer de 1995 , defende a aplicação das normas do CDC à Solvay do Brasil S.A., receptora de insumos da Petroquímica União S.A., sob o argumento de que haveria nesta relação um consumo intermédio - utilização pelas empresas dos bens e serviços necessários para o processo produtivo -, que deveria igualmente ser tutelado pelas normas consumeristas. O fundamento dessa aplicação das normas consumeristas ao consumo intermédio é o de que, para a garantia dos princípios constitucionais, que são viabilizados pela compatibilização do consumidor com a necessidade de desenvolvimento econômico e tecnológico, é preciso garantir a liberdade de iniciativa, o que deve ser feito por meio da defesa da concorrência. Assim, para a proteção do consumidor final, é preciso que os agentes econômicos da relação de consumo intermédio também sejam protegidos, pois as condições de fornecimento são tendencialmente melhores quando, do lado dos agentes fornecedores, exista um número elevado, ou pelo menos razoável, de empresas que entre si disputem a clientela. Defende o autor, na esteira do que se pretende demonstrar com o presente estudo, que, mesmo as sociedades empresárias, que não se enquadram no conceito de consumidor final, podem ser tuteladas pelas normas do CDC sempre que estiverem expostas às práticas comerciais abusivas previstas em tal Código, nos termos da equiparação prevista no artigo 29 desse mesmo diploma legal (Cf. TOMASETTI JÚNIOR, Alcides. Abuso de poder econômico e abuso de poder contratual. Revista dos Tribunais, São Paulo, v. 84, n. 715, p. 102-103, maio. 1995).

${ }^{366}$ Cf. MARQUES, Cláudia Lima. Contratos no Código de Defesa do Consumidor, cit,. 2002, p. 92.
} 
Na visão de ClÁudia LIMA MARQues, ainda, parece que, para harmonizar os interesses presentes no mercado de consumo, com vistas a reprimir de modo eficaz eventuais abusos de poder econômico e proteger os interesses econômicos dos consumidores-finais, o legislador quis conceder um poderoso instrumento nas mãos daquelas pessoas (mesmo que agentes econômicos) expostas às práticas abusivas. De acordo com esse entendimento, essas pessoas, mesmo não sendo 'consumidores stricto sensu', poderão se utilizar das normas especiais do referido Código, de seus princípios, de sua ética de responsabilidade social no mercado, de sua nova ordem pública, para combater as práticas comerciais abusivas ${ }^{367}$.

Ronaldo Porto Macedo JR., ainda, adverte que as mudanças que vêm sendo verificadas no mercado contemporâneo, particularmente a partir de 1970, impõem a necessidade de se visualizar mecanismos específicos para a proteção de diferentes tipos de consumidor e tipos contratuais. $\mathrm{O}$ tratamento padronizado do consumidor enquanto um novo sujeito universal de direitos acaba impedindo a escolha correta do mecanismo de proteção jurídica mais adequada ao caso concreto $^{368}$. Assim, seria possível conferir tratamento diferenciado, mas protetivo, em qualquer um dos casos, a consumidores finais, consumidores equiparados ou consumidores por conexão, consumidores pessoas físicas ou pessoas jurídicas, estas últimas a depender do porte, por exemplo etc.

Em síntese, por força da própria legislação pátria, há situações em que é possível se vislumbrar a aplicação do CDC também a empresários.

Na Argentina, por exemplo, a equiparação do empresário ao consumidor não é possível em razão do quanto estabelece o art. $2^{\circ}$ de sua Lei $n^{\circ} 24.240$, segundo o qual " $n o$ tendrán el carácter de consumidores o usuarios, quienes adquieran, almacenen, utilicen o consuman bienes o servicios para integrarlos en procesos de producción, transformación, comercialización o prestación a terceros". Da mesma forma, a definição legal de consumidor em diversos países europeus, como visto no item 3.1 desta dissertação, impediria a equiparação de empresários a consumidores em tais países. LORENZETTI, contudo, esclarece que o código brasileiro do consumidor não recepciona tal distinção, de maneira que a equiparação, no Brasil, é plenamente possível ${ }^{369}$.

\footnotetext{
${ }^{367}$ Cf. MARQUES, Cláudia Lima. Contratos no Código de Defesa do Consumidor, cit,. 2002, p. 294.

${ }^{368}$ MACEDO JR., Ronaldo Porto. Contratos relacionais e defesa do consumidor. São Paulo: Max Limonad, 1998. p. 268-269.

${ }^{369} \mathrm{O}$ mesmo autor, ainda, salienta que, apesar da impossibilidade de equiparação do empresário ao consumidor na Argentina, muitos contratos realizados fora do âmbito do consumo nesse país, mesmo na
} 
Custodio MiRAnda, a respeito do art. 29 do CDC, leciona que:

"Toda a interpretação deve ser a um tempo literal e lógica. Quer isso dizer que, quando o preceito citado determina que se estenda a proteção contratual, inclusive a proibição das cláusulas abusivas, dispensadas aos consumidores, a todos quanto estejam sujeitos a práticas nele previstas, não parece nem de longe querer equiparar, pura e simplesmente, aos contratos negociados o regime dos contratos de adesão [haja vista que esse autor entende que a aplicação do art. 51 do CDC restringe-se aos contratos de adesão, conforme será visto no capítulo seguinte]. Antes parece querer estender tal protecão, por razões de justica social, que agora ficam evidentes perante situacõos de desigual poder econômico das partes, de barganha ou de negociação, a todos quanto, e apenas a estes, pela sua especial posicão, ante as circunstâncias do caso concreto, não estejam em condiç̃es de poderem conformar o conteúdo do contrato, de influir na determinação de tal conteúdo, tendo de se sujeitar à imposição de uma das partes contratantes. O que quer dizer, em última análise, que é ao intérprete que compete efetuar tal verificação, em cada caso concreto, para que se conclua se, ante as circunstâncias, a situação é equiparável àquela outra, dos contratos de adesão $^{\text {"370 }}$ (grifos nossos).

Completa o autor, ainda, dizendo que a necessidade de se observar a autonomia privada e respeitar a força obrigatória das cláusulas contratuais sobre as partes pode não se verificar em certas relações contratuais, ainda que não se trate de contratos de adesão. Pode ocorrer, por exemplo, em contratos passíveis de negociação, em que uma das partes, por qualquer razão, tenha ficado impossibilitada de influir na determinação de todo ou parte do conteúdo contratual, proporcionando à outra a inserção de uma cláusula que acabe por lhe proporcionar uma vantagem desproporcional diante das circunstâncias, tornando-se, portanto, abusiva. Em tal hipótese, não seria necessária qualquer posição de supremacia de uma parte em relação à outra, bastando apenas que, em face das circunstâncias concretas, uma das partes, por um motivo razoavelmente aceitável, não tivesse conseguido impedir, por meio de seu poder de negociação, que a outra lhe impusesse condições que viessem a alterar gravemente o equilíbrio contratual"371.

Ora, esse parece ser exatamente o caso dos contratos de dependência econômica nas hipóteses em que se verificar um abuso dessa dependência por parte do contratante em posição privilegiada.

contratação empresária, podem ser submetidos a uma interpretação contra stipulatorem ou, até mesmo, ter suas cláusulas declaradas abusivas (Cf. LORENZETTI, Ricardo Luiz. Tratado de los contratos. Buenos Aires, Rubinzal-Culzoni Editores, 1999. t. 1, p. 141).

${ }^{370}$ Cf. MIRANDA, Custodio da Piedade Ulbadino. Contrato de adesão. São Paulo: Atlas, 2002. p. 172.

${ }^{371}$ Id. Ibid., p. 172-173. 
A tendência de constitucionalização do Direito Privado que se verifica nos dias de hoje, ademais, reforça o entendimento acima. De fato, pela aplicação direta dos princípios constitucionais nas relações de Direito Privado, tal qual o princípio da dignidade da pessoa humana ou o princípio da isonomia substancial, o CDC deveria ser aplicado até mesmo em relações jurídicas que não constituam propriamente relações de consumo, sempre que sejam indentificados os mesmos pressupostos que justificam a aplicação do $\operatorname{CDC}^{372}$.

\subsection{Principais conseqüências da aplicação do CDC aos contratos interempresariais: a disciplina das cláusulas abusivas}

Como vista acima, o CDC poderá ser aplicado aos contratos interempresariais em casos excepcionais, respeitadas algumas peculiaridades desse tipo de contrato e a lógica própria do sistema empresarial.

A incidência desse diploma legal num campo que, a princípio, não seria por ele contemplado pode ser justificada quando os institutos de direito civil e/ou do direito antitruste se mostrarem insuficientes para evitar ou corrigir os abusos praticados pelo contratante em posição de superioridade ou quando o remédio apresentado por tais ramos do direito for menos célere do que uma possível solução com base na aplicação do CDC. Tal solução deve ser vista como uma medida compensatória (assim como o é o próprio direito do consumidor), uma vez que não proporciona uma solução estrutural, mas visa corrigir algumas distorções dentro das possibilidades existentes em nosso ordenamento ${ }^{373}$.

Superada a dúvida que paira sobre a possível aplicação do CDC aos contratos interempresariais, urge tratar das principais consequiências que tal aplicação traria para o caso concreto. Em linhas gerais, seria possível estender ao empresário dependente economicamente de seu parceiro contratual os efeitos dos principais dispositivos do CDC que conferem maior proteção contratual ao consumidor, desde que respeitada a lógica do

\footnotetext{
${ }^{372} \mathrm{Cf}$. TEPEDINO, Gustavo. As relações de consumo e a nova teoria contratual. In: civil, cit., p. 213.

${ }^{373}$ TERESA NEGREIROS entende que a regulação dos contratos de adesão também deve ser entendida como uma medida compensatória. Segunda a autora, "o contrato de adesão é (...) um símbolo da atuação que a ordem jurídica passa então a ter na declarada tentativa de impedir a realização de certos resultados tidos por indesejáveis, instituindo medidas compensadoras, orientadas à proteção do aderente". Também o direito do consumidor como um todo é visto pela autora como uma medida compensatória, na medida em que a ordem contratual contemporânea, sensível à disparidade de poder negocial entre os contratantes, procurou compensá-la por meio da imposição de um regime de proteção à parte vulnerável, qual seja, o CDC (NEGREIROS, Teresa. op. cit., p. 381 e 389).
} 
sistema empresarial, como explanado anteriormente. Tome-se como exemplo a proteção contra a publicidade enganosa, a possibilidade de desconsideração da cláusula de eleição de foro, a repetição do indébito por valor igual ao dobro do excesso do pagamento anteriormente realizado, a disciplina das cláusulas abusivas prevista no art. 51 do diploma consumerista etc.

A possibilidade de aplicação da disciplina das cláusulas abusivas do CDC, contudo, chama atenção pelo fato de ser esta justamente uma das principais formas de abuso no âmbito dos contratos interempresariais. Daí porque optou-se por delimitar o tema do presente estudo à análise desse ponto específico, conforme será abordado a seguir. 


\section{CláuSUlas abuSivas}

\subsection{Definição de cláusulas abusivas}

Consideram-se cláusulas abusivas as disposições contratuais que atribuem vantagens excessivas a uma das partes, acarretando, em contrapartida, demasiada onerosidade à parte contrária e um injusto desequilíbrio contratual ${ }^{374}$.

As cláusulas abusivas podem existir em qualquer contrato, como se verá a seguir, mas os contratos de adesão são onde elas aparecem com maior freqüência, tendo campo em diversas direções, nas mais variadas áreas: financeira, industrial, comercial, de serviços, de hotelaria, de licenciamentos, de uso de bens alheios (estacionamentos, postos e outros), de conserto de bens (oficinas mecânicas, reparos em aparelhos eletrônicos e outros) etc ${ }^{375}$.

O controle dessas cláusulas parte do sentimento de que elas são condenáveis dentro de um sentido de justiça contratual. Sem dúvida alguma, uma cláusula abusiva confere a um dos contratantes uma vantagem excessiva, criando, por via de conseqüência, um desequilíbrio significativo entre os direitos e obrigações das partes decorrentes do contrato.

Mas nem todo desequilíbrio contratual decorre de uma cláusula abusiva. Existem outros tipos de desequilíbrios, como os existentes nos contratos a título gratuito ou nos contratos aleatórios, que encontram sua razão de ser na própria natureza do contrato. No caso das cláusulas abusivas, ao revés, o desequilíbrio resulta do abuso de poder econômico de um dos contratantes sobre o outro, ainda que este último seja bem informado. É por essas razões que se aduz que a diferença de posição econômica dos contratantes torna ilusória a livre negociação entre as partes.

A cláusula abusiva, assim, pode ser definida como aquela que traduz um abuso da posição de supremacia ostentada por um dos contratantes ${ }^{376}$. BUENO DE GODOY define a cláusula abusiva como aquela que:

“(...) vem marcada pela unilateralidade, que é resultado da posição de força, de superioridade de uma das partes contratantes, impondo um

\footnotetext{
${ }^{374}$ Cf. LÔBO, Paulo Luiz Neto. op. cit., p. 155.

${ }^{375}$ Cf. BITTAR, Carlos Alberto (Coord.). op. cit., p. 11.

${ }^{376}$ Cf. KARIMI, Abbas. Les clauses abusives et la théorie de l'abus de droit. Paris: E.J.A., 2001. p. 12-13.
} 
desequilíbrio contratual, de vantagens e riscos, que a ordem jurídica corrige ou, antes, impede" ${ }^{\text {"377 }}$.

Em decorrência da própria definição de cláusula abusiva, a qual é imposta no momento da conclusão do contrato, alguns autores deduzem que todas as questões que giram em torno dela devem ser situadas no terreno da formação do contrato, com forte influência sobre o direito de contratar e a autonomia da vontade ${ }^{378}$.

Isso não quer dizer, no entanto, que uma cláusula só poderá ser considerada abusiva se apresentar esse caráter já desde o momento da formação do contrato. Existem, na verdade, dois tipos de cláusulas abusivas: as que são de natureza abusiva e as que, a despeito de dita natureza, vêm a se tornar como tal no terreno da execução do contrato, por um abuso no exercício de determinados termos contratuais. Isso pode acontecer quando, por exemplo, os termos genéricos de uma cláusula permitem a um dos contratantes, durante a execução do contrato e diante de circunstâncias especiais, tirar vantagens anormais em prejuízo da parte contrária.

LORENZETTI, sintetizando essa idéia, atribui o caráter abusivo de uma cláusula em duas situações, a saber: (a) quando favorece desmedidamente a uma das partes em detrimento da outra, o que significa uma afetação da causa obrigacional ${ }^{379}$; ou (b) quando, embora não seja em si mesma abusiva, a cláusula desequilibra o contrato, afetando a função ou causa do negócio. Aqui, a obrigação repercute de forma mediata e a abusividade da cláusula será de difícil apreciação. Porém, como esclarece o autor, o caráter abusivo da cláusula contratual será apreciado tendo em vista a natureza dos bens e serviços que sejam objeto do contrato, as circunstâncias que concorreram para sua celebração, assim como todas as demais cláusulas do contrato e de outro contrato do qual porventura ele venha a depender ${ }^{380}$.

\footnotetext{
${ }^{377}$ GODOY, Cláudio Luiz Bueno de. op. cit., p. 49.

${ }^{378}$ JUNQUEIRA DE AZEVEDO ensina que "uma das mais fortes tendências do direito contratual atual, no sistema romano-germânico, é a de não admitir desequilíbrio injustificado entre os direitos e obrigações atribuídos às partes; a autonomia da vontade deve ser harmonizada com a solidariedade social" (AZEVEDO, Antonio Junqueira de. Cláusula cruzada de não-indenizar (cross-waiver of liability) ou cláusula de não-indenizar com eficácia para ambos os contratantes. Renúncia ao direito de indenização. Promessa de fato de terceiro. Estipulação em favor de terceiro. [Parecer]. In: Estudos e pareceres de direito privado, cit., p. 200).

${ }^{379}$ JUNQUEIRA DE AZEVEDO, para diferenciar a causa obrigacional da causa do negócio jurídico, atribui à primeira o termo "kausa".

${ }^{380}$ Cf. LORENZETTI, Ricardo Luiz. op. cit., p. 166.
} 
Em qualquer um dos casos, porém, o contratante que se beneficia excessivamente da cláusula contratual estará agindo contrariamente ao dever de execução das obrigações conforme a boa-fé. Por conseqüência, esses dois tipos de cláusulas abusivas podem ser sancionados pelo mesmo instituto, qual seja, a boa-fé objetiva, conjugada a outros dois princípios contratuais modernos: a função social do contrato e o equilíbrio contratual.

Ocorre que, justamente por se tratar de um instituto muito abrangente e pouco objetivo, essa solução acaba muitas vezes por deixar de tutelar diversas situações em que uma das partes é prejudicada pelo abuso da outra, principalmente naqueles casos em que a cláusula não é abusiva por sua própria natureza, mas se configura potencialmente abusiva.

Ademais, ao contrário da solução pela aplicação do art. 424 do Código Civil brasileiro, que se restringe ao campo dos contratos de adesão, ou pela aplicação do CDC, a repressão das cláusulas abusivas pela boa-fé objetiva não encontra uma sanção prédeterminada pelo ordenamento para a ocorrência desse tipo de cláusula.

A ineficácia do sistema de proteção dos contratantes em posição de inferioridade explica-se, em grande parte, pela recusa de se aplicar o direito comum em matéria de repressão às cláusulas abusivas. Com efeito, muitas das técnicas do direito comum poderiam ser aplicadas às situações de cláusulas abusivas, como a questão da validade e dos vícios de consentimento. Entretanto, todas essas técnicas não servem de base para uma luta sistemática contra tais cláusulas, pois não constituem fundamento jurídico para a anulação de toda e qualquer cláusula abusiva.

O único princípio do direito comum que tem vocação geral, não se limitando a uma classe particular de cláusulas abusivas, e que, para parte da doutrina nacional e alienígena, seria capaz de tutelar, também, aquelas que são apenas potencialmente abusivas é aquele que fundamenta a teoria do abuso de direito ${ }^{381}$. Entretanto, da forma como essa teoria foi disciplinada no Código Civil de 2002, como visto acima, a solução das cláusulas abusivas com base no abuso de direito dependeria de critérios subjetivos.

${ }^{381}$ Cf. KARIMI, Abbas. op. cit., p. 7-10. 


\subsection{Cláusulas abusivas no Código Civil e no CDC}

As cláusulas abusivas, como visto, podem existir tanto nos contratos de adesão como nos contratos negociados, sejam eles de consumo ou não. No caso dos contratos negociados entre profissionais, a ausência, no passado, de regras proibitivas expressas contra cláusulas que favorecessem desproporcionalmente uma das partes, em detrimento da outra, emanava da idéia de que o contrato, como manifestação da vontade individual de cada um, fazia lei entre as partes, as quais tinham ampla liberdade de dispor da forma como melhor lhes conviesse, presumindo-se, aí, uma igualdade de posição econômica - o que nem sempre efetivamente se verifica.

Nesta última hipótese, nota-se um claro conflito entre o princípio da justiça comutativa e o da liberdade contratual. E é por isso que se deve sempre analisar cada situação especificamente, para se determinar qual o princípio que deve prevalecer diante das circunstâncias do caso concreto ${ }^{382}$.

CUSTODIO MiRANDA esboça bem essa realidade, ao concluir que:

“(...) se, por um lado, o Estado tem de intervir para assegurar a igualdade na contratação, especialmente para remover os inconvenientes que resultam do modo de formação dos contratos de adesão, tendo em vista que cada um dos sujeitos dessa relação pertence a grupos ou categorias sócio-econômicas diversas, fato que os coloca em posições díspares de força e poder de barganha, não pode, por outro lado, ignorar-se que até onde essa situação de desequilíbrio de forças não ocorra ou não se verifique, a parte deve poder desfrutar da liberdade contratual, tendo de se responsabilizar em face da outra parte contratante, pela assunção de todas as obrigações livremente assumidas ${ }^{383}$.

Após o advento do Código Civil de 2002, passou a existir uma regra proibitiva expressa - o art. 424 desse diploma legal - contra as cláusulas abusivas também para os contratos entre profissionais, mas desde que o modo de contratação tenha sido por adesão. Para aqueles contratos que não sejam de adesão ou que não se enquadrem nas hipóteses do art. 424 do Código Civil, por seu turno, será preciso analisar detidamente as circunstâncias

\footnotetext{
${ }^{382}$ Como anotam ALEXY e DWORKIN, nos conflitos de princípios, a grande questão é saber qual dos princípios em conflito tem mais peso e maior importância no caso concreto. Ao contrário dos conflitos de normas, a questão não gira em torno do campo da validade (Cf. ALEXY e DWORKIN apud NEGREIROS, Teresa. op. cit., p. 274).

${ }^{383}$ MIRANDA, Custodio da Piedade Ulbadino. op. cit., p. 170-171.
} 
do caso concreto, pois, em regra, terá de prevalecer a liberdade contratual, não podendo o Estado interferir nas cláusulas livremente pactuadas pelas partes. Apenas a título de exceção, se aceita a equiparação a consumidor, poder-se-á cogitar da aplicação do art. 51 do CDC a esses contratos celebrados entre profissionais.

O tratamento diferenciado para essas situações de exceção se justifica exatamente porque, nesses casos, a autonomia privada resta frustrada. MENEZES CoRDEIRO, referindose à autonomia privada, identifica exatamente os casos em que tal princípio não deve prevalecer, devendo haver uma restrição direta à liberdade contratual, a saber:

"[a opção efetiva no momento da contratação] (...) pode ser frustrada pela ignorância do contratante, pela sua dependência económica ou outra, por situações de monopólio, pela necessidade impreterível de contratar de imediato ou, simplesmente, por a contraparte se recusar a alterar a proposta ou a contraproposta que tenha formulado" ${ }^{\text {,384 }}$ (grifos nossos).

CANARIS, por sua vez, na exposição do pensamento de ZWEIGERT e KÖTZ, explica que, hoje, a liberdade contratual tem por condição a igualdade econômica e social das partes negociantes. Isso, segundo dizem esses autores, é a razão pela qual a liberdade contratual não existe, no fundo, senão para contratos entre grandes empresas a propósito de objetos atípicos. Na opinião dos autores, a justiça contratual (e já não a liberdade contratual) é, hoje em dia, em todo o mundo, o princípio material do funcionamento do direito dos contratos ${ }^{385}$.

\subsubsection{Cláusulas abusivas no Código Civil}

O Código Civil deixou de trazer um regramento sistemático para o problema das cláusulas abusivas. O único artigo que trata especificamente sobre o assunto é o art. 424 que estabelece que: "nos contratos de adesão, são nulas as cláusulas que estipulem a renúncia antecipada do aderente a direito resultante da natureza do negócio".

\footnotetext{
${ }^{384}$ CORDEIRO, António Manuel da Rocha e Menezes. op. cit., v. 1, p. 653.

${ }^{385} \mathrm{Cf}$. CANARIS, Claus-Wilhelm. A liberdade e a justiça contratual na "sociedade de direito privado". In: MONTEIRO, António J. M. Pinto (Coord.). Contratos: actualidade e evolução. Porto: Coimbra Ed., 1997. p. 54 .
} 
Nota-se que o alcance desse art. 424 restringe-se aos contratos de adesão ${ }^{386}$. Como bem afirmou MENEZES CORDEIRO, porém, critérios rígidos e formais não bastam para dar conta do problema das cláusulas abusivas. Também é possível cogitar a existência de cláusulas no âmbito de contratos que não sejam de adesão e que também impliquem sua desnaturalização, acabando com a função social a que lhe era inerente ${ }^{387}$.

Nessas circunstâncias, à luz do direito pátrio, que prevê a função social dos contratos, não seria crível sustentar que um contrato que tenha sido desnaturalizado mantenha-se intacto e deva ser conservado, tão somente porque não atenda aos requisitos exigidos pelo art. 424 do Código Civil acima transcrito ${ }^{388}$.

Aliás, o art. 424, além de restringir seu campo de aplicação aos contratos de adesão, limita-se aos casos de abusividade da cláusula desnaturalizante do contrato ${ }^{389}$, sendo certo que podem existir outras formas de abusividade de uma cláusula, e não somente aquelas que desnaturalizem o negócio ${ }^{390}$.

Alguns autores entendem que a aplicação desse art. 424 é ainda mais restrita, devendo-se levar em conta a natureza do contrato. Ganha espaço, aqui, uma nova dicotomia no campo contratual ${ }^{391}$, que é aquela que busca atribuir diferentes efeitos e usar

\footnotetext{
${ }^{386} \mathrm{O}$ art. 424 do Código Civil não define o que seria "contrato de adesão". No entender de CLÁUDIA LiMA MARQUES, não seria possível um diálogo sistemático complementar com o CDC para se estabelecer a definição de contrato de adesão entre empresários, para fins de aplicação desse artigo do Código Civil, isto é, tal definição será outra, que não a do art. 54 do CDC (Cf. MARQUES, Cláudia Lima. Diálogo entre o Código de Defesa do Consumidor e o novo Código Civil: do "diálogo das fontes" no combate às cláusulas abusivas, cit., p. 93). Vale apontar, contudo, que o Deputado Fiuza apresentou proposta de alteração legislativa para que o art. 423 do Código Civil fosse ampliado para incluir, dentre outras coisas, a definição de contratos de adesão, sendo que tal proposta foi rejeitada por Vicente Arruda - relator nomeado na Comissão de Redação, Constituição e Justiça da Câmara dos Deputados - sob o argumento de que a doutrina, jurisprudência e a própria legislação já definiram os contratos de adesão em razão do que estabelece o art. 54 do CDC (Cf. TARTUCE, Flavio. Função social dos contratos: do Código de Defesa do Consumidor ao Código Civil de 2002, cit., p. 321-322).

${ }^{387}$ Cf. CORDEIRO, António Manuel da Rocha e Menezes. Da boa-fé no direito civil, cit., p. 658-660.

${ }^{388}$ JUNQUEIRA DE AZEVEDO explica que "se há desigualdade real entre os interessados e o negócio, que deveria servir de instrumento de colaboração, passa a ser instrumento de abuso (por exemplo, nos atos em que alguém é incapaz, ou nos feitos sob erro, dolo, coação e, muito claramente, nos em que há lesão), ele deixa de "valer". O mesmo acontece se, depois de feito, se torna fator de desequilíbrio (caso da onerosidade excessiva). Deixa, ainda, de preencher a sua função, quando quebra a harmonia social, quer parcialmente, ferindo interesse de terceiros (casos de simulação e fraude contra credores), quer globalmente (por abuso de poder econômico, por exemplo)" (AZEVEDO, Antonio Junqueira de. Ciência do direito, negócio jurídico e ideologia. In: . Estudos e pareceres de direito privado, cit., p. 52).

${ }^{389}$ A expressão "direito resultante da natureza do negócio" constante do art. 424 do Código Civil constitui uma cláusula geral, que deve ser preenchida pelo juiz no caso concreto.

${ }^{390} \mathrm{Um}$ dos exemplos atualmente existentes, que foi inclusive objeto do Enunciado 364 do Conselho da Justiça Federal, é a cláusula de renúncia antecipada ao benefício de ordem nos contratos de fiança que tenham sido contratados por adesão, situação bastante comum nos setores imobiliário e locatício.

${ }^{391} \mathrm{Cf}$. AZEVEDO, Antonio Junqueira de. Rapport brésilien sur la révision contractuelle In: ASSOCIATION HENRI CAPITANT DES AMIS DE LA CULTURE JURIDIQUE FRANÇAISE. Journées Bresiliennes. Conferência proferida em São Paulo, em 26 de maio de 2005.
} 
critérios de interpretação distintos para os contratos que tenham por finalidade a obtenção de lucro (contratos de lucro ou empresariais) e os contratos que visem a satisfazer necessidades pessoais (contratos existenciais) $392 \mathrm{e} 393$.

Assim, por exemplo, mesmo no caso de um contrato de adesão em que houvesse uma cláusula de renúncia antecipada a direito resultante da natureza do negócio, não necessariamente deveria ser decretada a nulidade da cláusula em questão, por exemplo, se no âmbito de um contrato de lucro, em troca dessa cláusula, houvesse uma clara vantagem econômica.

Para esses autores, o art. 424 deveria ser rigorosamente observado apenas naqueles contratos que visassem à satisfação de necessidades pessoais, próprias à dignidade da pessoa humana, ante a dependência existencial que a parte tem com relação ao bem ou serviço pretendido por meio do contrato. Em tais contratos, e desde que de adesão, toda e qualquer cláusula que desnaturalizasse o negócio deveria ser declarada nula.

Já no caso dos contratos de empreendimento profissional, com claro objetivo de lucro pelas partes, a interpretação do art. 424 não deveria ser tão rígida, não sendo preciso declarar a nulidade da cláusula em todos os casos, ainda que ela estivesse no âmbito de um contrato de adesão e implicasse renúncia antecipada de um direito resultante da natureza do negócio, pois, na grande maioria dos casos, haverá riscos a serem suportados e direitos a renunciar com vistas à obtenção de outras vantagens, o que é próprio do regime da livreiniciativa.

Ademais, entende essa corrente doutrinária que os empresários não merecem a mesma proteção destinada às pessoas físicas no âmbito de um contrato existencial, haja vista que devem assumir os riscos da atividade, sendo certo que, se praticarem maus

\footnotetext{
392،Essa nova dicotomia, que defendemos, 'contrato existencial/contrato empresarial', é, a nosso ver, a verdadeira dicotomia contratual do século XXI. Por força da renovação dos princípios contratuais e da freqüência de sua concretização, não se pode mais empregar a palavra 'contrato' sem consciência dessa nova dicotomia; ela é operacional e está para o século XXI, como a de 'contrato paritário/contrato de adesão' esteve para século XX' (AZEVEDO, Antonio Junqueira de. Natureza jurídica do contrato de consórcio. Classificação dos atos jurídicos quanto ao número de partes e quanto aos efeitos. Os contratos relacionais. A boa-fé nos contratos relacionais. Contratos de duração. Alteração das circunstâncias e onerosidade excessiva. Sinalagma e resolução contratual. Resolução parcial do contrato. Função social do contrato [Parecer]. Revista dos Tribunais, São Paulo, v. 94, n. 832, p. 124, fev. 2005).

${ }^{393}$ Alguns autores chegam a falar inclusive na despatrimonialização do Direito Privado, que seria o outro lado da moeda da personificação desse ramo do Direito. Tal despatrimonialização não representa logicamente um desinteresse do Direito Privado pelas relações econômicas. Significa apenas o reconhecimento de que os bens e direitos patrimoniais não constituem fins em si mesmos, devendo ser tratados pela ordem jurídica como meios para a realização da pessoa humana. Se antes o ter prevalecia sobre o ser, hoje nota-se uma inversão no elemento mais importante desse binômio (Cf. SARMENTO, Daniel. op. cit., p. 90-91).
} 
negócios, deverão ser excluídos do mercado, com base no princípio básico da concorrência.

O critério proposto para essa nova dicotomia é preponderantemente subjetivo, ou seja, somente os contratos entre pessoas físicas poderiam receber o tratamento dado aos contratos existenciais. Os contratos entre pessoas jurídicas seriam sempre tratados como contratos de lucro ${ }^{394}$.

Tal critério, contudo, merece algumas críticas. Em muitos casos, como visto, a existência da própria pessoa jurídica depende de um contrato específico e, por trás de uma pessoa jurídica, sempre existem pessoas físicas - os empresários - a depender muitas vezes daquela atividade empresarial para a sua sobrevivência e de sua família. Em tais casos, portanto, a questão também gira em torno da dignidade da pessoa humana, em última análise $^{395}$.

$\mathrm{O}$ argumento de que as pessoas físicas, ao decidirem virar empresárias para adquirir os benefícios, especialmente fiscais, destinados às pessoas jurídicas, não poderiam, depois, alegar inexperiência, hipossuficiência ou vulnerabilidade para se furtar à aplicação das regras dos contratos de lucro, sob pena de restar caracterizado o venire contra factum proprium, não é suficiente para afastar esse entendimento.

Isso, porque, em alguns casos, a pessoa física é forçada a se tornar empresária, uma vez que a única forma de exercer a atividade é fazendo parte de uma sociedade empresária. A título ilustrativo, podemos fazer uma analogia com a situação das cooperativas, que, embora não recebam tratamento empresarial, demonstram claramente a dependência de alguns profissionais à entidade, já que é bastante comum a situação de profissionais que apenas conseguem exercer sua atividade se se filiarem a uma sociedade cooperativa ${ }^{396}$. Em

\footnotetext{
${ }^{394} \mathrm{O}$ critério deixa de ser exclusivamente subjetivo apenas em alguns casos limítrofes (a "zona cinzenta"), como no caso das fundações, associações, entidades religiosas e partidos políticos. Para tais entidades, deve-se buscar a finalidade do contrato em questão, de modo que, se estiverem no exercício de suas atividades comuns, serão equiparadas às pessoas físicas, mas quando agirem com o fito de lucro, deverão receber o tratamento dado aos contratos de lucro.

${ }^{395}$ Isso porque, superado o personalismo ético kantiano, o princípio da dignidade da pessoa humana, visto sob a ótica da nova ética, exige, além da vida em si e da integridade física e psíquica, o respeito às condições mínimas de vida, condições essas que podem ser materiais, como a obtenção da casa própria, por exemplo, e o respeito aos pressupostos mínimos de liberdade e convivência igualitária entre os homens, que, por sua vez, abrange, dentre outros, o direito à liberdade, sendo certo que alguns casos de abusividade de cláusulas contratuais, como no abuso de uma cláusula de exclusividade ou de não concorrência, podem ferir a dignidade da pessoa humana sob esse aspecto do direito à liberdade (Cf. AZEVEDO, Antonio Junqueira de. Caracterização jurídica da dignidade da pessoa humana. In: Estudos e pareceres de direito privado, cit., p. 18 e 21$)$.

${ }^{396} \mathrm{O}$ caso da cooperativa, contudo, é bastante específico, uma vez que, embora seja, por força de lei, uma sociedade simples, nos termos do art. 982, parágrafo único, do Código Civil, que já é dotada de regras e
} 
outros casos, às vezes a pessoa até está disposta a se sujeitar às regras dos contratos de lucro, mas em razão de um abuso da dependência econômica pela parte privilegiada, que é uma atitude contrária à justiça contratual e ao direito de um modo geral, fica sujeita a uma situação de extrema injustiça, sendo justificável, nesse caso, equipará-la às pessoas físicas, para aplicação das regras dos contratos existenciais no caso concreto. Nessas hipóteses, não há que se falar em venire contra factum proprium, portanto.

TERESA NEGREIROS também apresenta outra dicotomia de grande relevância para o direito contratual pós-moderno, conhecido como o paradigma da essencialidade. Tal paradigma constitui um importante instrumento para se distinguir os contratos à luz das diferentes funções que desempenham em relação às necessidades existenciais do contratante, determinando o melhor regime a ser aplicado ao caso concreto. No caso dos contratos que tenham por função satisfazer uma necessidade existencial do contratante, deverá ser aplicado um regime de caráter tutelar, ampliando-se o campo de aplicação dos novos princípios contratuais. Por outro lado, os contratos que tenham por objeto bens supérfluos, destinados a satisfazer preferências que não configuram necessidades básicas da pessoa, devem se sujeitar a uma disciplina mais liberal, de forma a sofrer maior influência dos princípios clássicos ${ }^{397}$. Tais contratos, portanto, sujeitar-se-ão à regra da mínima intervenção heterônoma ${ }^{398}$.

A introdução no Direito Privado de conceitos que antes não eram objeto de preocupação por parte do legislador ganhou relevo com a falência do Estado na prestação de serviços úteis ou essenciais à coletividade, o que levou à privatização de tais serviços e à consequente transferência de responsabilidade aos agentes privados a quem tais serviços são transferidos ${ }^{399}$. Tal situação acabou por explicitar algumas deficiências do Direito Privado, de um modo geral.

A criteriologia tradicional, como aponta TERESA NEGREIROS, confere um mesmo tratamento a um contrato de compra e venda de uma jóia e de um remédio, ou a um contrato de prestação de serviços de entretenimento e de assistência médica. Os elementos

princípios próprios, distintos daqueles empresariais propriamente ditos, tal entidade não se enquadra no conceito pleno de sociedade, já que a cooperativa em si mesma não tem fím lucrativo. As regras e princípios específicos de direito empresarial, assim, não devem ser aplicados às cooperativas (Cf. BORBA, José Edwaldo Tavares. op. cit., p. 9-10).

${ }^{397}$ NEGREIROS, Teresa. op. cit., p. 31-32.

${ }^{398}$ Cf. Id. Ibid., p. 463.

${ }^{399}$ Cf. Id. Ibid., p. $482-483$. 
materiais socialmente relevantes são completamente desprezados. O bem contratado é tratado com total indiferença ${ }^{400}$.

O próprio critério utilizado no art. 424 do Código Civil, que restringe sua aplicação aos contratos de adesão, demonstra claramente a falta de preocupação com o bem contratado. Embora a distinção entre contratos de adesão e contratos negociados seja extremamente relevante para a determinação da disciplina que será aplicada ao caso concreto, existem outros elementos materiais também importantes que poderiam contribuir para um regramento das cláusulas abusivas de forma mais justa, em linha com o princípio da dignidade da pessoa humana e demais princípios constitucionalmente assegurados.

O paradigma da essencialidade, portanto, atribui ao direito contratual também a responsabilidade de tratar dos problemas sociais, ainda que devam existir na sociedade outros mecanismos específicos para a correção de tais problemas ${ }^{401}$. A própria autora, porém, adverte que referido paradigma é apenas um critério a mais de diferenciação dos contratos, pois, atualmente, a teoria geral do contrato está sujeita a diversos paradigmas e é regida por vários princípios, que se intercomunicam ${ }^{402}$.

O CDC, ao tipificar a "fraqueza do consumidor", por exemplo, menciona alguns elementos, como a idade, saúde, conhecimento ou condição social do consumidor que servem como medida para a avaliação da relevância do bem cuja utilização ou aquisição é objeto do contrato $^{403}$. Já a Diretiva 93/13/CEE, em seus considerandos, deixa expresso que a natureza dos bens ou serviços deverá influir na apreciação do caráter abusivo das cláusulas dos contratos de consumo.

O paradigma da essencialidade ganha especial relevo naquelas situações, ora tratadas, que estão, a princípio, à margem do sistema de proteção do consumidor. Em tais situações, sempre que se verificar um desequilíbrio semelhante àquele pressuposto nas relações entre consumidores e fornecedores, a essencialidade do bem poderá ser invocada como fundamento para se impor o mesmo regime tutelar atribuído aos consumidores ${ }^{404}$.

\footnotetext{
${ }^{400}$ Cf. NEGREIROS, Teresa. op. cit., p. 364.

${ }^{401}$ Como leciona TERESA NEGREIROS, "o paradigma da essencialidade não é, evidentemente, capaz de dar solução às desigualdades sociais, tampouco de assegurar aos que nada têm aquilo que lhes seja essencial para viver dignamente. Contudo, a consciência dos limites do Direito - em especial, do direito civil - e de seu papel como agente de transformação não pode levar o jurista a se despir de toda e qualquer responsabilidade social" (Id. Ibid., p. 486).

${ }^{402}$ Cf. Id. Ibid., p. 342.

${ }^{403}$ Cf. Id. Ibid., p. 36-37.

${ }^{404}$ Cf. Id. Ibid., p. 489.
} 
A essencialidade do bem contratado também deve ser um critério para balizar o nível de vulnerabilidade do contratante, pois para a extensão dos efeitos do CDC a alguns contratos interempresariais não basta a mera caracterização da vulnerabilidade. É preciso distinguir os diferentes níveis de vulnerabilidade e, por conseguinte, também os diversos conceitos de abusividade contratual, para se determinar o regime contratual mais adequado ao caso concreto.

A existência de dicotomias como forma de se determinar o melhor regime aplicável ao caso concreto é uma tendência não só no direito contratual brasileiro, mas em todo o mundo. Nos Estados Unidos, por exemplo, a interpretação contratual e o regramento aplicável também diferem conforme o contrato seja business-to-business ou business-toconsumer. Ao contrário dos países da civil law, porém, que tendem a criar regras detalhadas, especificando os termos contratuais que devam ser considerados abusivos quando inseridos em contratos business-to-consumer, os Estados Unidos, a exceção dos contratos de cartão de crédito e outros poucos que possuem regulação específica, optaram por criar uma ampla definição de abusividade que poderá ser aplicada pelas cortes e agências regulatórias a qualquer tipo de contrato. Tal mecanismo está em linha com o sistema da common law, cabendo ao aplicador do direito, no caso concreto, determinar se a cláusula contratual em questão é abusiva ou não. Para tanto, deverá ter mente se o contrato é business-to-business ou business-to-consumer ${ }^{405}$.

Independentemente das dicotomias acima analisadas, fato é que, a princípio, os demais casos sujeitos ao atual Código Civil, que não se enquadrem dentre as hipóteses do art. 424, deverão ser solucionados por meio da aplicação dos princípios contratuais modernos, o que não é suficiente para uma luta sistemática contra as cláusulas abusivas, especialmente porque tais princípios dependem de critérios subjetivos para sua aplicação e não atribuem expressamente a sanção cabível, como faz o art. 424, que atribui a sanção de nulidade.

Assim, dependendo das circunstâncias do caso concreto, especialmente naquelas hipóteses de abuso da dependência econômica, já abordadas acima, outra solução poderá se impor, conforme será estudado a seguir.

\footnotetext{
${ }^{405}$ PETTY, Ross D.; HAMILTON, Jennifer. Seeking a single policy for contractual fairness to consumers: a comparison of U.S. and E.U. efforts. The Journal of Consumer Affairs, v. 38, n. 1, p. 149, Summer 2004.
} 


\subsubsection{Cláusulas abusivas no CDC}

$\mathrm{O} \mathrm{CDC}^{406}$, se comparado ao Código Civil, traz um regramento muito mais extenso no que diz respeito às cláusulas abusivas ${ }^{407}$.

$\mathrm{O}$ art. 51 desse Código, abandonando os critérios da liberdade da vontade e da intenção das partes, estabeleceu critérios objetivos de constatação da abusividade do contrato. Para tanto, enumerou as cláusulas que entende por abusivas ${ }^{408}$, fulminando a elas a nulidade de pleno direito.

O rol trazido por referido artigo, além de já ser relativamente extenso, ainda prevê, dentre seus incisos, dois que se caracterizam como cláusulas gerais (incisos IV e XV) e que, portanto, conferem ao juiz poderes para identificar cláusulas abusivas nos casos concretos sempre que estabelecerem obrigações consideradas iníquas, abusivas, que coloquem o consumidor em desvantagem exagerada, ou sejam incompatíveis com a boa-fé ou a equidade, ou ainda quando estiverem em desacordo com o sistema de proteção ao consumidor $^{409}$.

É importante esclarecer, também, que na caracterização da abusividade de uma cláusula não se deve recorrer ao uso da analogia, uma vez que tal medida restringe o exercício da autonomia privada. Para Custodio MiRANDA, tal restrição não tem

\footnotetext{
${ }^{406}$ A disciplina das cláusulas e práticas abusivas do CDC recebeu forte influência do direito alemão (AGBGesetz, de 9 de setembro de 1976) e do direito português (Decreto-lei 446/85, de 25 de outubro de 1985), conforme explica CLÁUdia LiMA MARQUES (MARQUES, Cláudia Lima. A Lei 8.078/90 e os direitos básicos do consumidor, cit., p. 49).

${ }^{407}$ Conforme explica JunQueIRA DE AZEvedo, "o Código de Defesa do Consumidor, que foi feito, como se sabe, depois do Projeto de Código Civil, está muito mais atualizado do que este. As cláusulas abusivas têm um vasto elenco no art. 51, inclusive com norma de fechamento. O próprio Ministério da Justiça publicou mais duas listas com 29 cláusulas, no mês de março de 1999; são cláusulas abusivas em matéria de planos de saúde, de cartão de crédito, de transporte aéreo etc." (AZEVEDO, Antonio Junqueira de. Insuficiências, deficiências e desatualização do Projeto de Código Civil (atualmente, código aprovado) na questão da boa-fé objetiva nos contratos. In:____. Estudos e pareceres de direito privado, cit., p. 154).

${ }^{408}$ Cf. FONSECA, João Bosco Leopoldino da. Cláusulas abusivas. Revista de Direito do Consumidor, São Paulo, v. 16, p. 59, 1995.

409“ $O$ rol de cláusulas abusivas, no art. 51 do CDC, tem bem o espírito de ecletismo, próprio do direito brasileiro. Admitiu, como fundamento dos vários incisos, tanto a explicação francesa de abusividade, que é a de desequilíbrio entre direitos e deveres (cf. incisos IX, X, XI e XIII), quanto a alemã, de boa-fé (cf. incisos IV e VIII), não se limitando, de resto, às duas orientações (cf. inciso XIV). Quanto ao seu "sistema”, o CDC foi também dúplice: não ficou numa dicção que, à moda de cláusula geral, abarcasse toda e qualquer hipótese, nem optou por soluções tópicas, com enumeração exaustiva de cláusulas abusivas. $O$ art. $51 \mathrm{fez}$ as duas coisas: trouxe lista de cláusulas abusivas e inciso genérico. Essa solução mista tem, por sua vez, ao nosso ver, dupla vantagem: resolve problemas concretos (com a lista) e dá ao juiz arma para modificar cláusulas abusivas não previstas (com o inciso genérico)" (AZEVEDO, Antonio Junqueira de. Relação jurídica que não é de consumo. Destinatário final. Cláusula abusiva [Parecer], cit., p. 233).
} 
cabimento, pois o Estado não deve ser visto como guardião dos direitos e interesses da parte dita mais fraca, já que não lhe cabe a função de defesa do indivíduo, enquanto sujeito de uma relação determinada, mas somente enquanto membro da comunidade ou de determinado grupo social ${ }^{410}$.

Isso, porém, não se confunde com a aplicação restrita desse artigo somente aos contratos de adesão, como querem fazer crer alguns autores.

Para PAUlo LÔBO, por exemplo, o CDC, ao disciplinar sobre as cláusulas abusivas em seus arts. 51 a 53, não autoriza interpretação extensiva, conferindo o alcance de suas disposições somente aos contratos de adesão a condições gerais ${ }^{411}$. As cláusulas abusivas de que trata o Código em comento, para esse autor, com alcance mais restrito que o abuso de direito e a lesão, situam-se apenas no âmbito das condições gerais, sendo inaplicável às relações contratuais comuns ${ }^{412}$.

Em que pese tal entendimento, essa não nos parece ser a posição mais acertada, já que a redação do art. 51 do $\mathrm{CDC}$, em nenhum momento, restringe expressamente sua aplicação aos contratos de adesão.

De fato, muitas das cláusulas enumeradas nesse art. 51 só fazem sentido quando inseridas em contratos de adesão, porém isso não quer dizer que aqueles incisos que poderiam ter aplicação a outras formas de contratação não possam ser a elas aplicados.

Em nosso entender, a única implicação é que, na contratação por adesão, o critério a ser aplicado deverá ser totalmente objetivo, ou seja, verificada qualquer uma das cláusulas enumeradas no art. 51 do referido Código, obrigatoriamente ela deverá ser considerada nula, independentemente da comprovação, por qualquer das partes, de sua abusividade e prejuízos causados.

Já no caso dos contratos negociados, total ou parcialmente, será preciso, em primeiro lugar, analisar se a aplicação do inciso reclamado faz sentido em tais contratos, para, somente então, verificar as circunstâncias do caso concreto, de forma a se determinar se a cláusula é abusiva. Aqui, portanto, o critério a ser aplicado não deve ser totalmente objetivo, demandando uma atividade um pouco mais árdua por parte do aplicador do

\footnotetext{
${ }^{410}$ Cf. MIRANDA, Custodio da Piedade Ulbadino. op. cit., p. 215-216.

${ }^{411}$ Segundo PAULO LÔBO, "as condições gerais dos contratos constituem regulação contratual predisposta unilateralmente e destinada a se integrar de modo uniforme, compulsório e inalterável a cada contrato de adesão que vier a ser concluído entre predisponente e o respectivo aderente" (LÔBO, Paulo Luiz Neto. op. cit., p. 24).

${ }^{412}$ Cf. LÔBO, Paulo Luiz Neto. op. cit., p. 157.
} 
direito. Especialmente nos casos dos incisos IV e XV, não há razão para restringi-los aos contratos de adesão, já que, justamente por serem cláusulas gerais, como visto acima, a aplicação de tais incisos dependerá sempre da análise do caso concreto.

Compartilha de tal entendimento JUNQUEIRA DE AZEVEDO, para quem:

\begin{abstract}
"o art. 51 trouxe um rol de hipóteses específicas de cláusulas abusivas, ao lado de uma hipótese genérica de 'fechamento' da lista (inciso XV); ora, a previsão das cláusulas abusivas específicas impede que, sobre elas, se façam distinções, quer haja quer não haja discussão prévia, quer o contrato seja quer não seja de adesão"413.
\end{abstract}

Nota-se que a intenção do legislador com tais incisos foi justamente a de não limitar a hipóteses restritas a repressão das cláusulas abusivas, possibilitando ao aplicador do direito determinar, em cada caso concreto, quando uma cláusula deva ser considerada abusiva ou não.

Feitas tais observações, impõe-nos abordar sobre as conseqüências do reconhecimento de abusividade de uma cláusula pelo regramento do CDC. Como regra básica, caracterizada uma cláusula abusiva, há de se impor sua desqualificação.

Os diversos ordenamentos, porém, empregam distintos mecanismos para desqualificar as cláusulas abusivas. O nosso Código do Consumidor, objeto do presente estudo, por exemplo, optou por declarar nulas de pleno direito as cláusulas mencionadas nos dezesseis incisos de seu art. $51^{414}$. A lei brasileira, porém, dispõe no parágrafo $2^{\circ}$ desse mesmo artigo que a "nulidade de uma cláusula contratual abusiva não invalida o contrato". Impõe-se o princípio da conservação, desde que guardado o equilíbrio das posições contratuais.

O controle das cláusulas abusivas, no direito brasileiro, pode se dar tanto em nível abstrato quanto concreto. Em consonância com o art. 51, parágrafo $4^{\circ}$, do $\mathrm{CDC}$, ao Ministério Público cabe o controle preventivo das cláusulas abusivas por meio da análise dos documentos onde se encontram redigidas as cláusulas constantes de formulário, isto é, cabe ao Ministério Público o controle das cláusulas de documentos ainda unilaterais, cuja intenção é a de que venham a se tornar objeto de contrato de adesão. A declaração de

\footnotetext{
${ }^{413}$ AZEVEDO, Antonio Junqueira de. A arbitragem e o direito do consumidor (arbitration and the consumer's rights). In: . Estudos e pareceres de direito privado, cit., p. 244.

${ }^{414}$ Cf. ALTERINI, Atílio Aníbal. Os contratos de consumo e as cláusulas abusivas. Revista de Direito do Consumidor, São Paulo, v. 15, p. 17, 1995.
} 
nulidade, nesse caso, foge do campo dos contratos efetivamente existentes, não se tratando propriamente de nulidade de negócio jurídico de consumo ${ }^{415}$.

Já o controle concreto das cláusulas abusivas se dá na forma dos arts. 81 e 82 do CDC. Todos os legitimados previstos nesse artigo podem postular em juízo a nulidade das cláusulas abusivas constantes de contratos, inclusive o Ministério Público. A grande distinção entre o Ministério Público e os demais legitimados é que àquele é facultado exercer também o controle preventivo, como visto.

A ação que pode ser proposta para o controle das cláusulas abusivas encontra previsão, inclusive, para obtenção de tutela liminar. Conforme a gravidade da cláusula abusiva, o CDC faculta ao juiz, em seu art. 84, parágrafo $3^{\circ}$, suspendê-la liminarmente, determinando que se cumpra o contrato, com desconsideração da cláusula, ou até mesmo suspendendo a execução do contrato como um todo ${ }^{416}$.

\subsection{Equiparação de empresário a consumidor e as cláusulas abusivas}

Nas hipóteses de existência de cláusulas abusivas em contratos firmados entre profissionais, não enquadradas nas situações previstas no art. 424 do Código Civil, torna-se necessária a verificação das peculiaridades de cada caso concreto, haja vista que relegar aos princípios contratuais a função de reprimir tais cláusulas pode acabar por não propiciar a solução mais justa e equânime na prática, pois é possível que os princípios contratuais deixem de tutelar determinadas situações em que seja patente a abusividade e desproporcionalidade dos direitos e obrigações entre as parte contratantes (mesmo que profissionais).

Assim, a melhor solução, em alguns casos, parece ser equiparar a parte sujeita à cláusula abusiva aos consumidores, a fim de tornar possível a aplicação da solução prevista no $\mathrm{CDC}$ a esses casos excepcionais.

Aliás, o próprio diploma consumerista abre espaço para esse tipo de interpretação, ao introduzir o conceito de consumidor-equiparado do art. 29, como visto anteriormente.

\footnotetext{
${ }^{415}$ Cf. ALVIM, Arruda. Cláusulas abusivas e seu controle no direito brasileiro. Revista de Direito do Consumidor, São Paulo, v. 20, p. 43-51, 1996.

${ }^{416}$ Cf. Id. Ibid., p. 48.
} 


\subsection{Aplicação das disposições sobre cláusulas abusivas do CDC aos contratos interempresariais}

Diante da imposição de uma cláusula usualmente considerada abusiva em um contrato interempresarial, ganha relevo a questão da reciprocidade, sendo preciso verificar se a cláusula dita abusiva está presente para apenas um dos contratantes ou se para os dois. Ou, ainda, se existe no contrato uma vantagem que compense a desvantagem atribuída pela referida cláusula.

Mas, talvez, o melhor critério a ser utilizado diga respeito ao animus da parte que contrata, ou seja, é preciso buscar saber se a parte realmente queria renunciar àquele direito ou, ainda, se ela teria a opção de não renunciar ao direito, caso assim não desejasse.

Nas relações de consumo propriamente ditas, essas questões têm menor importância, uma vez que a abusividade é presumida. Nos casos de contratos de adesão fora do âmbito de uma relação de consumo, poderíamos ter a aplicação do art. 424 do Código Civil (caso a situação específica se enquadrasse dentre as hipóteses de aplicação desse artigo, já analisadas anteriormente). Mas, nas hipóteses de contratos que não sejam de adesão fora do âmbito de consumo stricto sensu, ou mesmo nos casos dos contratos de adesão entre profissionais que não se enquadrem nas hipóteses de aplicação do art. 424 do Código Civil, a análise de tais questões faz-se extremamente necessária.

Nestas duas últimas situações, que dependerão da análise do caso concreto, deve-se levar em conta as condições específicas do contratante mais fraco frente ao contrato e a seu parceiro em posição privilegiada, para se saber se, naquele caso específico, está ocorrendo abuso de uma situação de dependência econômica, por exemplo.

Respeitadas as opiniões em contrário ${ }^{417}$, é possível entender que, uma vez verificado o abuso de dependência econômica por parte do contratante privilegiado e

\footnotetext{
${ }^{417}$ CRISTIANO ZANETTI, por exemplo, entende que os contratos de adesão que não tratem de relações de consumo devem ser disciplinados necessariamente pelo art. 424 do Código Civil, devendo-se respeitar, em tais casos, a natureza do negócio, o que torna sempre necessário examinar o contrato concluído em concreto, ao contrário do que ocorreria com um contrato sujeito à incidência do $\mathrm{CDC}$, já que, nesta última hipótese, há algumas cláusulas que são proibidas de modo absoluto. Segundo o autor, porém, embora seja comum a celebração de contratos de adesão entre sociedades empresárias, tais contratos não estão sujeitos à disciplina do CDC, em que pese a força expansiva do art. 29 desse texto legal (Cf. ZANETTI, Cristiano de Sousa. Direito contratual contemporâneo: a liberdade contratual e sua fragmentação, cit., p. 271-272). Também TARTUCE entende que o art. 51 do CDC somente pode ser aplicado aos contratos de consumo, sendo indeclináveis a importância e eficácia do art. 424 do Código Civil para os contratos de adesão de natureza civil (Cf. TARTUCE, Flavio. Função social dos contratos: do Código de Defesa do Consumidor ao Código Civil de 2002, cit., p. 324).
} 
considerando-se a equiparação do empresário a consumidor no caso concreto, como visto acima, ter-se-ia a aplicação de todas as disposições pertinentes aos consumidores por equiparação do $\mathrm{CDC}$, especialmente no que tange às cláusulas abusivas, ao contrato sob análise, ainda que celebrado entre empresários. 


\section{ENTENDIMENTO JURISPRUDENCIAL}

O entendimento exposto ao longo do presente trabalho já vem sendo corroborado inclusive por alguns dos principais Tribunais brasileiros, a exceção do Supremo Tribunal Federal $-\mathrm{STF}^{418}$ e de alguns poucos tribunais estaduais, que ainda parecem adotar a Teoria Finalista Clássica.

Os pronunciamentos do STF sobre o tema, contudo, são bastante escassos, tendo em vista a competência desse tribunal. Nos últimos anos, o pronunciamento de maior repercussão em relação a temas de Direito do Consumidor foi, sem dúvida, o julgamento da Ação Direta de Inconstitucionalidade n ${ }^{\circ} 2591$ promovida pela Confederação Nacional do Sistema Financeiro, em 07 de junho de 2006 (“ADIn dos Bancos”).

A partir do julgamento dessa ADIn, criou-se uma confusão acerca do entendimento do STF sobre a aplicação do CDC aos bancos e a questão da equiparação de empresários a consumidores. Muito se ouviu falar que, a partir daquele julgamento, o STF teria dado maior abrangência ao $\mathrm{CDC}$, inclusive para os empresários. Tal confusão, contudo, não procede.

De fato, o julgamento da ADIn dos Bancos enterrou a dúvida que pairava sobre a constitucionalidade do art. $3^{\circ}, \S 2^{\circ}$, do $\mathrm{CDC}$, que declarava expressamente que tal código deveria ser aplicado às instituições financeiras, de crédito e securitárias. É preciso esclarecer, porém, que o CDC sempre foi aplicado, desde sua edição, a todas as relações de consumo, inclusive aquelas estabelecidas com as instituições financeiras, de crédito e securitárias $^{419}$. O julgamento da ADIn dos Bancos apenas confirmou a constitucionalidade de tal dispositivo. Para sua aplicação, contudo, continua se fazendo necessária a caracterização da relação de consumo e, aqui sim, entra a discussão sobre a equiparação de empresários a consumidores. Assim, a ADIn dos Bancos em nada alterou o conceito de relação de consumo, tampouco as definições de consumidor e fornecedor, como parecem

\footnotetext{
${ }^{418} \mathrm{Na}$ Sentença Estrangeira Contestada 5.847-1, Rel. Min. Maurício Corrêa, j. 01.12.1999, o STF deixou claro que o consumo intermediário não deve ser regulado pelo CDC. Somente os bens e serviços destinados ao consumidor final, e não aqueles usados diretamente na produção de outros, estão abrangidos pela lei especial.

${ }^{419}$ Também o Superior Tribunal de Justiça - STJ assim já entendia, conforme pode se denotar da Súmula 297 desse tribunal, que estabelece que "o Código de Defesa do Consumidor é aplicável às instituições financeiras".
} 
acreditar alguns. Pelo contrário, no voto do Sr. Ministro Carlos Velloso, há expressa menção de que a comprovação da vulnerabilidade continua se fazendo necessária.

Já o Superior Tribunal de Justiça - STJ durante muito tempo adotou, na solução de conflitos, a Teoria Finalista Clássica, para a definição de consumidor. Entre os anos de 1990 e 2004, passou-se a notar, dentro do próprio STJ, decisões aparentemente contraditórias, que ora argumentavam com base na Teoria Finalista Clássica, ora adotavam muito mais facilmente a aplicação do CDC a contratos firmados entre profissionais.

Para ilustrar, pode-se citar dois acórdãos que defenderam a aplicação da Teoria Finalista Clássica durante o período retro mencionado: um deles em ação movida por concessionária de veículos contra instituição financeira, em que se pleiteava a redução da cláusula de multa contratual inserida em contrato de financiamento bancário, e outro em ação cautelar de busca e apreensão movida por instituição financeira contra uma empresa química, pela qual se objetivava obter a posse de um automóvel e de um caminhão dados em garantia do financiamento bancário destinado ao desenvolvimento da atividade empresarial da ré. A sentença de procedência havia sido reformada em apelação pelo Tribunal de Justiça do Rio Grande do Sul, que, sob o prisma do CDC, entendeu que as cláusulas sobre taxas de juros no contrato de financiamento eram excessivamente onerosas, mas foi novamente reformada pelo STJ. Seguem abaixo as ementas:

"MÚTUO. REDUÇÃO DA MULTA CONTRATUAL DE 10\% PARA $2 \%$. INEXISTENNCIA NO CASO DE RELAÇÃO DE CONSUMO. - Tratandose de financiamento obtido por empresário, destinado precipuamente a incrementar a sua atividade negocial, não se podendo qualificá-lo, portanto, como destinatário final, inexistente é a pretendida relação de consumo. Inaplicação no caso do Código de Defesa do Consumidor. Recurso especial não conhecido." (STJ; RESP nº. 218505/MG; $4^{\mathrm{a}}$ Turma; Relator: Min. Barros Monteiro; Julgado em 16.09.1999).

“ALIENAÇÃO FIDUCIÁRIA EM GARANTIA. BUSCA E APREENSÃO. ÂMBITO DA DEFESA. INCIDÊNCIA DO CÓDIGO DE DEFESA DO CONSUMIDOR. BENS JÁ INTEGRANTES DO PATRIMÔNIO DO DEVEDOR. TAXA DE JUROS. CAPITALIZAÇÃO MENSAL. COMISSÃO DE PERMANÊNCIA. APLICAÇÃO DA TR. MORA DOS DEVEDORES CONFIGURADA. (...) - Tratando-se de financiamento obtido por empresário, destinado precipuamente a incrementar a sua atividade negocial, não se podendo qualificá-lo, portanto, como destinatário final, inexistente é a pretendida relação de consumo. Inaplicação no caso do Código de Defesa do Consumidor. (...) Recurso especial conhecido, em parte, e provido." (STJ; RESP n ${ }^{\circ} .264126 / \mathrm{RS} ; 4^{\mathrm{a}}$ Turma; Relator: Min. Barros Monteiro; Julgado em 08.05.2001). 
Também é possível citar bons exemplos de acórdãos que defenderam, durante o período acima mencionado, a aplicação do CDC a contratos firmados entre profissionais. Tais acórdãos, em sua maioria, estão relacionados ao setor bancário ou de transportes, conforme segue:

“CONTRATO DE MÚTUO COM EMISSÃO DE CÉDULA DE CRÉDITO COMERCIAL, GARANTIDO POR ALIENAÇÃO FIDUCIÁRIA. CÓDIGO DE DEFESA DO CONSUMIDOR. MICROEMPRESA. 1. O Código de Defesa do Consumidor incide nos contratos de mútuo, típicos contratos de adesão, no caso, com emissão de cédula de crédito comercial e garantido por alienação fiduciária. 2. Tratando-se de contrato de adesão, sendo a ré microempresa, pertinente é a aplicação do art. $6^{o}$, VIII, do Código de Defesa do Consumidor, superando-se a cláusula de eleição de foro, com vistas à facilitação da defesa. 3. Recurso especial conhecido e provido." (STJ; RESP n. ${ }^{\circ} 468148 / \mathrm{SP} ; 3^{\mathrm{a}}$ Turma; Relator: Min. Carlos Alberto Menezes Direito; Julgado em 02.09.2003).

"CONTRATOS BANCÁRIOS - CONTRATO DE REPASSE DE EMPRÉSTIMO EXTERNO PARA COMPRA DE COLHEITADEIRA AGRICULTOR - DESTINATÁRIO FINAL - INCIDÊNCIA - CÓDIGO DE DEFESA DO CONSUMIDOR - COMPROVAÇÃO - CAPTAÇÃO DE RECURSOS - MATÉRIA DE PROVA - PREQUESTIONAMENTO AUSÊNCIA. I - O agricultor que adquire bem móvel com a finalidade de utilizá-lo em sua atividade produtiva, deve ser considerado destinatário final, para os fins do artigo $2^{\circ}$ do Código de Defesa do Consumidor. II - Aplica-se o Código de Defesa do Consumidor às relações jurídicas originadas dos pactos firmados entre os agentes econômicos, as instituições financeiras e os usuários de seus produtos e serviços. (...) Recurso especial não conhecido, com ressalvas quanto à terminologia." (STJ; RESP n. ${ }^{\circ}$ 445854/MS; $3^{\text {a }}$ Turma; Relator: Min. Castro Filho; Julgado em 02.12.2003).

"Arrendamento mercantil. Código de Defesa do Consumidor. Juros. Comissão de permanência. 1. O contrato de arrendamento mercantil está subordinado ao regime do Código de Defesa do Consumidor, não desqualificando a relação de consumo o fato do bem arrendado destinar-se às atividades comerciais da arrendatária. 2. Os contratos celebrados pelas instituições financeiras, salvo expressa previsão legal, estão sob o alcance da Súmula ${ }^{\circ} 596$ do Supremo Tribunal Federal. 3. A jurisprudência da Corte permite a cobrança da comissão de permanência, desde que pactuada, vedada, em qualquer caso, a sua cumulação com a correção monetária. 4. Recurso especial conhecido e provido, em parte." (STJ; RESP n. ${ }^{\circ}$ 235200/RS; $3^{\text {a }}$ Turma; Relator: Min. Carlos Alberto Menezes Direito; Julgado em 24.10.2000).

"Transporte de mercadoria. Dano. Aplicação do Código de Defesa do Consumidor. Precedentes da Corte. 1. A jurisprudência da Corte consolidou-se no sentido de que, tratando-se do transporte de mercadoria, configurada a relação de consumo, aplica-se o Código de Defesa do Consumidor. 2. Decidiu a Corte que em caso de pedido de reparação de danos 'o lapso decadencial é de cinco anos (art. 27 da Lei $n^{\circ}$ 8.078, de 11.09.90)' (REsp $n^{\circ}$ 258.132/SP, Relator o Senhor Ministro Barros Monteiro, DJ de 19/03/01). 3. Recurso especial conhecido e 
provido." (STJ; RESP n. ${ }^{\circ}$ 329587/SP; $3^{\text {a }}$ Turma; Relator: Min. Carlos Alberto Menezes Direito; Julgado em 02.05.2002).

"Ação de indenização. Contrato de transporte. Embargos de declaração. Código de Defesa do Consumidor. Prescrição. (...) 2. Aplica-se a prescrição do Código de Defesa do Consumidor (art. 27), em caso de ação de indenização decorrente de dano causado em mercadoria durante o respectivo transporte marítimo, não importando para a definição do destinatário final do serviço de transporte o que é feito com o produto transportado. No caso, o serviço de transporte foi consumado com a chegada da mercadoria no seu destino, terminando aí a relação de consumo, estabelecida entre a transportadora e a empresa que a contratou. 3. Recurso especial conhecido e provido." (STJ; RESP n. ${ }^{\circ}$ 286441/RS; $3^{\mathrm{a}}$ Turma; Relator para o Acórdão: Min. Carlos Alberto Menezes Direito; Julgado em 07.11.2002).

Com o passar dos anos, o STJ notou a necessidade de haver uma consolidação e unificação no entendimento sobre a aplicação do $\mathrm{CDC}$ aos contratos firmados entre profissionais. Tal movimento começou em 2004, quando ainda era possível notar decisões com divergência de opinões entre os ministros do referido tribunal, conforme se observa no RESP n. ${ }^{\circ}$ 541867/BA, da $2^{\text {a }}$ Seção, cujo Relator foi Min. Antônio de Pádua Ribeiro, julgado em 10 de novembro de 2004.

Em tal acórdão, o voto vencedor do Min. Barros Monteiro determinou que:

“(...) a lei consumerista, à evidência, não veio contemplar o comerciante, puro e simples, que no seu campo de atuação profissional, adquire bens e contrata serviços com a finalidade de implementar a sua atividade negocial. $O$ produto adquirido não se destina ao consumo próprio, daí por que inexiste a relação de consumo a atrair a competência da vara especializada. Em realidade, a relação de consumo restringe-se à autora, 'Central de Tintas Ltda.', e à pessoa que adquiriu, em seu estabelecimento comercial, o produto no varejo. O que faz parte da cadeia econômica da atividade do comerciante, não pode ser tida como relação de consumo".

Por outro lado, o Min. Jorge Scartezzini já reconhecia a necessidade de haver:

“(...) certo abrandamento na interpretação finalista, na medida em que se admite, excepcionalmente e desde que demonstrada 'in concreto' a vulnerabilidade técnica, jurídica ou econômica, a aplicação das normas do Código de Defesa do Consumidor a determinados consumidores profissionais, como pequenas empresas e profissionais liberais. Quer dizer, ao revés do preconizado pelos maximalistas, não se deixa de perquirir acerca do uso, profissional ou não, do bem ou serviço; apenas, como exceção, e à vista da hipossuficiência concreta de determinado adquirente ou utente, não obstante seja um profissional, passa-se a considerá-lo consumidor. Tome-se o exemplo acima citado do advogado que adquire livros e computadores para usá-los profissionalmente. Para 
os maximalistas, como visto, quer se cuide de um só profissional, iniciante ou não, ou de um grande e conceituado escritório de advocacia, aplicar-se-iam as normas do Código de Defesa do Consumidor. Os finalistas, por outro lado e a princípio, excluiriam a relação da incidência de referida legislação em ambos os casos; excepcionalmente, porém, nas hipóteses de profissional iniciante ou de uma pequena banca $e$, ainda, caso se tenha, no pólo oposto da relação contratual uma grande fornecedora, a relação passaria a ser regida pela legislação consumerista".

De 2004 em diante, o STJ reconheceu a necessidade de se abrandar a Teoria Finalista Clássica, diante das necessidades fáticas, para atender situações em que a vulnerabilidade se encontrava demonstrada no caso concreto, ainda que nas relações formadas entre fornecedores e consumidores-empresários, sem, contudo, banalizar a aplicação do CDC.

Em razão dessa constatação, a jurisprudência do STJ se firmou no sentido de aceitar, excepcionalmente, a aplicação do CDC à pessoa jurídica empresária, quando evidenciada a sua vulnerabilidade no caso concreto, em linha com o que expõe a Teoria Finalista Aprofundada, anteriormente analisada.

Segundo a Ministra Nancy Andrighi:

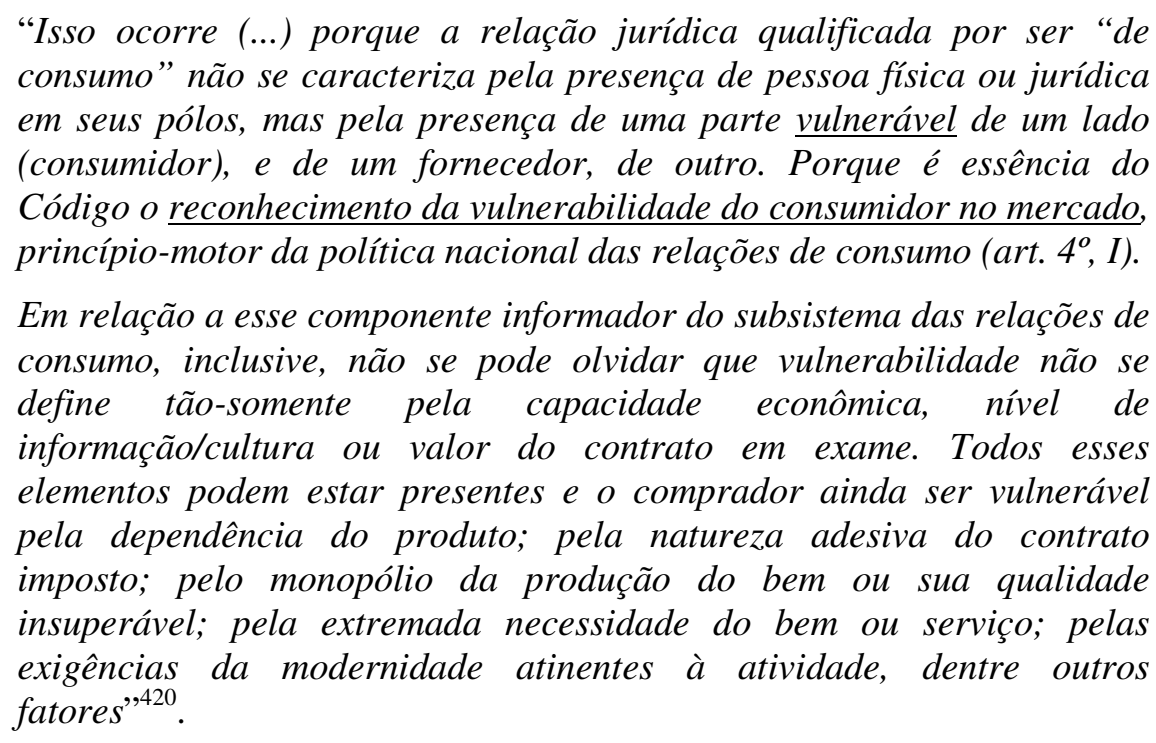

No mesmo sentido do acórdão acima, pode-se citar: Resp 476428-SC; $3^{\mathrm{a}}$ Turma; Rel. Min. Nancy Andrighi; j. 19.04.2005; Resp 684.613-SP, $3^{\text {a }}$ Turma, Rel. Min. Nancy

${ }^{420}$ Resp 476.428-SC, $3^{\text {a }}$ Turma, Rel. Min. Nancy Andrighi, j. 19.04.2005. 
Andrighi, j. 21.06.2005; Resp 661.145-ES, 4 ${ }^{\text {a }}$ Turma, Rel. Min. Jorge Scartezzini, j. 22.02.2005; Resp 687.239-RJ, $3^{\mathrm{a}}$ Turma, Rel. Min. Nancy Andrighi, j. 06.04.2006.

Além dos casos de aplicação do CDC para a repressão das cláusulas abusivas nos contratos entre empresários em que uma das partes seja vulnerável, o STJ também aplica o conceito de consumidor-equiparado para outras hipóteses, como no caso de propaganda enganosa, haja vista que a propaganda, como atividade de consumo que é, também pode ser causa de equiparação de empresário a consumidor ${ }^{421}$.

No entendimento do STJ, contudo, a incidência do CDC deve ser afastada se verificado o expressivo porte financeiro ou econômico da pessoa tida por consumidora, do contrato celebrado entre as partes ou de outra circunstância capaz de afastar, em tese, a vulnerabilidade econômica, jurídica ou técnica ${ }^{422}$.

Um bom exemplo dessa situação é a aquisição por pessoa, jurídica ou não, de equipamentos hospitalares de valor vultoso, motivo que, em tese, afastaria a vulnerabilidade dos adquirentes, bem como o fato de a pessoa ter sido devidamente assessorada por profissionais qualificados no momento da celebração do contrato. Além disso, é preciso analisar se a cláusula em questão é realmente capaz de gerar prejuízos a uma das partes, como, por exemplo, quando uma cláusula de foro gera onerosidade excessiva para a parte recorrente, dificuldade de acesso ao Judiciário ou restrição à produção de defesa em juízo ${ }^{423}$.

O STJ, portanto, já começou a estender a aplicação do CDC a alguns consumidores intermediários, bem como a sociedades empresárias, desde que demonstrada, no caso concreto, a fragilidade técnica, jurídica ou econômica em face do outro pólo da obrigação, não sendo suficiente, por exemplo, uma empresa alegar a tutela desse código simplesmente por ser menor, em termos econômicos, do que a outra parte.

Uma vez consolidado esse entendimento do STJ, a tendência é que todos os demais tribunais brasileiros venham a segui-lo, o que, aliás, já vem ocorrendo em alguns estados brasileiros.

\footnotetext{
${ }^{421}$ Nesse sentido, cite-se o Resp 327.257-SP, $3^{\text {a }}$ Turma, Rel. Min. Nancy Andrighi, j. 22.06.2004.

${ }^{422}$ Assim já foi decidido em inúmeros precedentes do STJ, a saber: Resp 687.239-RJ, $3^{\text {a }}$ Turma, Rel. Min. Nancy Andrighi, j. 06.04.2006; Resp 648.613-SP, $3^{\mathrm{a}}$ Turma, Rel. Min. Nancy Andrighi, j. 01.07.2005; Resp 684.613-SP, $3^{\text {a }}$ Turma, Rel. Min. Nancy Andrighi, j. 21.06.2005; Resp 541.867-BA, $3^{\text {a }}$ Turma, Rel. Min. Antônio de Pádua Ribeiro, Rel. p/ Acórdão Min. Barros Monteiro, j. 16.05.2005; AEResp 561.853MG, $3^{\text {a }}$ Turma, Rel. Min. Antônio de Pádua Ribeiro, j. 24.05.2004; Resp 519.946-SC, $4^{\text {a }}$ Turma, Rel. Min. César Asfor Rocha, j. 28.10.2003; Resp 457.398-SC, 4ª Turma, Rel. Min. Ruy Rosado de Aguiar, j. 09.12.2002.

${ }^{423}$ A esse respeito, vide: Resp 201.195-SP, 4 a Turma, Rel. Min. Ruy Rosado de Aguiar, j. 07.12.2000.
} 
Rio Grande do Sul, Minas Gerais e Rio de Janeiro, por exemplo, já passam a dar sinais de que terão seus conceitos alinhados ao entendimento do STJ.

O Tribunal de Justiça do Rio Grande do Sul adotava, na grande maioria dos casos, a Teoria Finalista Clássica ${ }^{424}$, rejeitando a incidência do CDC aos contratos firmados entre empresários. Recentemente, contudo, passou a flexibilizar tal teoria, em linha com o que vem defendendo o STJ.

Em decisão unânime no agravo de instrumento no. 597036102, a Sexta Câmara Cível do Tribunal de Justiça do Rio Grande do Sul houve por bem, na lide decorrente de dissenso sobre o cumprimento de um contrato de franquia, negar provimento ao pedido da franqueadora para não aplicação das regras consumeristas sobre eleição de foro ao contrato em questão.

O fundamento do desembargador Antonio Janyr Dall'Agnol Junior, relator do processo, foi justamente o da equiparação do franqueado a consumidor, nos termos do art. 29 do CDC. Segundo ele, a "exposição às práticas" de que trata o mencionado art. 29 implica:

\begin{abstract}
"justamente a idéia de sujeição. Este o sentido que se há de extrair: evidenciado o desequilíbrio entre os figurantes do negócio, qualquer que seja ele, portanto inclusive os que não se enquadrem como 'de consumo', incidem os dispositivos dos dois capítulos referidos. A regra contida no art. 29 do CDC (...) evidencia-se como verdadeiro canal de oxigenação do ordenamento jurídico comum. Foi através dele que se generalizou, evidenciado o desequilíbrio contratual, vale dizer, a vulnerabilidade de um dos figurantes do negócio jurídico, entre outras, a aplicação das cláusulas abusivas" ${ }^{\natural 25}$.
\end{abstract}

O Tribunal de Justiça de Minas Gerais, que durante muitos anos oscilou entre decisões que adotavam a Teoria Finalista Clássica $^{426}$ e decisões que adotavam a Teoria

\footnotetext{
${ }^{424}$ A título ilustrativo, cabe mencionar dois acórdãos do Tribunal de Justiça do Rio Grande do Sul, a saber: AC 70003041530-Giurá, 5a Cam. Cível, Rel. Des. Clarindo Favretto, j. 01.11.2001, v.u., e AC 70009627761-Viamão, 9a Cam. Cível, Rel. Des. Luís Augusto Coelho Braga, j. 26.10.2005, v.u.. No primeiro deles, concluiu-se que: "o autor não se encaixa no conceito de consumidor, pois que para a Teoria Finalista a 'destinação final', cuja idéia vem concebida no artigo $2^{o}$ do Código de Defesa do Consumidor, é a econômica, e não a fáctica. Assim, destinatário final é o não-profissional, a pessoa física que adquire o produto para consumo próprio. (...) Há que se fazer essa distinção, pois que se assim não fosse, todo aquele que adquire produto enquadrar-se-ia no conceito de consumidor". Já no segundo, podese notar a prevalência da Teoria Finalista Clássica pelo seguinte trecho: "o CDC adotou a teoria finalista na definição de consumidor. Assim, reconhecida a posição do apelante como consumidor intermediário não há que se falar na aplicação das regras protetivas das relações de consumo".

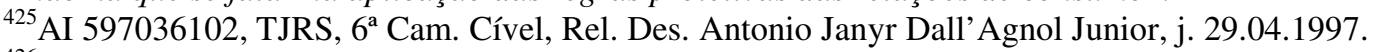

${ }^{426}$ Nesse sentido: AI 1.0024.06.246830-1/003(1), TJMG, $18^{\mathrm{a}}$ Cam. Cível, Rel. Des. Unias Silva, j. 26.02.2008; AI 462.299-9, TJMG, 9a Cam. Cível, Rel. Des. Irmar Ferreira Campos, j. 13.08.2004; CC 365.132-1, TJMG, $3^{\mathrm{a}}$ Cam. Cível, Rel. Des. Edílson Fernandes, j. 28.08.2002; AI 377.508-6, TJMG, $4^{\mathrm{a}}$
} 
Maximalista $^{427}$, vem atualmente optando pela aplicação do CDC aos contratos entre empresários, com base no conceito de consumidor equiparado de que trata o art. 29 deste código, sempre que constatada a vulnerabilidade no caso concreto ${ }^{428}$.

Para ilustrar, é possível citar o agravo $\mathrm{n}^{\mathrm{o}}$. 1.0024.05.736814-4/001 ${ }^{429}$, no qual o Tribunal entendeu por bem declarar nula de pleno direito a cláusula de eleição de foro fixada pela McDonald’s Comércio de Alimentos Ltda. em dois de seus contratos de franquia, sob o argumento de que a vulnerabilidade dos franqueados, face ao franqueador, era patente, além de os contratos de franquia em questão caracterizarem-se como contratos de adesão.

Já o Tribunal de Justiça do Rio de Janeiro até pouco tempo atrás adotava a Teoria Finalista em todos os seus julgados, aplicando a Teoria Maximalista somente em casos excepcionais - notadamente no setor agrícola e bancário - e desde que o profissional não utilizasse o produto adquirido para transformação. A linha de argumentação que era utilizada pode ser verificada na Apel. Cível no 2009.001.48587, 5ª Cam. Cível, Rel. Des. Cristina Tereza Gaulia, j. 15.09.2009.

Recentemente, porém, tal tribunal tem alterado sua postura, de forma a alinhar seu entendimento com a evolução jurisprudencial verificada no STJ. É possível notar diversos julgados, a partir de 2008, que já adotam a Teoria Finalista Aprofundada ou Mitigada. Na maioria desses acórdãos o CDC também não foi aplicado ao caso sob análise, mas, em todos eles, o fundamento não foi mais a Teoria Finalista Clássica, mas sim o fato de não ter restado comprada a vulnerabilidade do profissional no caso concreto ${ }^{430}$. Prova disso é que

Cam. Cível, Rel. Des. Alvimar de Ávila, j. 28.08.2002; AI 372.657-4, TJMG, $3^{\text {a }}$ Cam. Cível, Rel. Des. Mauro Soares Freitas, j. 07.08.2002.

${ }^{427}$ Conforme Apel. Cível no 1.0446.05.000386-7/001, TJMG, $18^{\text {a }}$ Cam. Cível, Rel. Des. Elpídio Donizetti, j. 18.11.2008; Apel. Cível no 1.0024.05.641140-8/001, TJMG, 14 $4^{\mathrm{a}}$ Cam. Cível, Rel. Des. Rogério Medeiros, j.

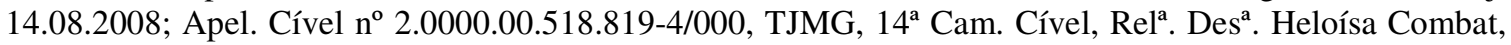

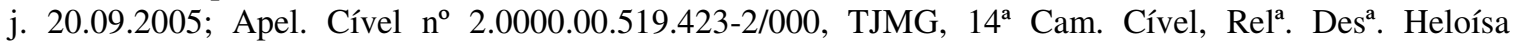
Combat, j. 20.09.2005; Apel. Cível no 2.0000.00.515.147-1/000, TJMG, 14 ${ }^{\mathrm{a}}$ Cam. Cível, Rela ${ }^{\mathrm{a}}$. Des ${ }^{\mathrm{a}}$. Heloísa Combat, j. 29.06.2005.

${ }^{428}$ Nos embargos infringentes $n^{\circ} 1.0470 .01 .002177-7 / 003(1)$, foi adotada a Teoria Finalista Aprofundada, mas houve voto divergente do Relator - Sr. Des. Wagner Wilson - que defendeu a não incidência do CDC com base nos conceitos da Teoria Finalista Clássica (embargos infringentes no 1.0470.01.002177-7/003(1), TJMG, 15ª Cam. Cível, Rel. Des. Wagner Wilson, j. 27.03.2008). Na apelação n ${ }^{\circ} 1.0024 .06 .207799-5 / 001$, em que foi adotada a Teoria Finalista Aprofundada, houve voto divergente da $\mathrm{Sr}^{\mathrm{a}}$. Des ${ }^{\mathrm{a}}$. Electra Benevides, mas o fundamento para tal voto não foi a Teoria Finalista Clássica, mas sim o fato de tal desembargadora ter entendido que, no caso concreto, não havia vulnerabilidade por parte do escritório de advocacia que pleiteava a incidência do CDC em contrato firmado com empresa vendedora de softwares (Apel. Cível $\mathrm{n}^{\circ}$ 1.0024.06.207799-5/001, TJMG, $10^{a}$ Cam. Cível, Rel. Dês. Cabral da Silva, j. 02.06.2009).

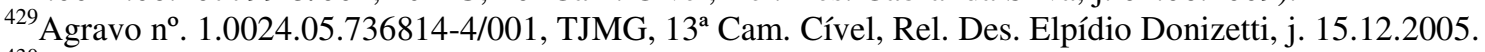

${ }^{430}$ Conforme Apel. Cível no 2008.001.25798, TJRJ, 16a Cam. Cível, Rel. Des. Agostinho Teixeira de Almeida Filho, j. 10.02.2009; Apel. Cível no 2008.001.59839, TJRJ, 6 ${ }^{\mathrm{a}}$ Cam. Cível, Rel. Des. Suimei Meira Cavalieri, j. 18.03.2009; Apel. Cível no 2009.001.28496, TJRJ, 20ª Cam. Cível, Rel. Des. Marco Antonio 
já existe inclusive julgado que decidiu pela incidência do CDC ao caso concreto, uma vez caracterizada a vulnerabilidade do profissional, nos termos da Apel. Cível $\mathrm{n}^{\circ}$ 2009.001.06998, TJRS, 8ª Cam. Cível, Rel. Des. Ana Maria Oliveira, j. 07.04.2009.

Finalmente, o Tribunal de Justiça de São Paulo ainda parece um pouco mais reticente com o abrandamento da Teoria Finalista ${ }^{431}$. Sua postura, ainda bastante conservadora, é a de evitar ao máximo a aplicação do CDC a contratos firmados entre empresários. Os julgados consultados mostram claramente a preferência do tribunal pela Teoria Finalista sempre que os negócios realizados pelo empresário em busca da aplicação do CDC estiverem relacionados a sua atividade produtiva ${ }^{432}$. Apenas um de seus desembargadores - o Sr. Des. Virgilio de Oliveira Junior, a favor da Teoria Maximalista fez consignar em diversos acórdãos seu voto vencido, pois defendia a aplicação do CDC ao caso concreto $^{433}$.

Referido tribunal, contudo, sempre tentou manter seu entendimento alinhado ao STJ em relação ao tema da equiparação de empresários a consumidores, assim, tudo indica que, em breve, também se verificará um abrandamento da Teoria Finalista no Tribunal de Justiça de São Paulo.

Nota-se, portanto, que a jurisprudência brasileira, em consonância com a evolução da teoria contratual, vem aceitando cada vez mais freqüentemente a aplicação do CDC aos contratos entre profissionais, desde que caracterizada a vulnerabilidade de uma das partes no caso concreto, já tendo estabelecido, inclusive, alguns critérios de balizamento para se saber quando deve haver, a título de exceção, a incidência desse diploma legal às relações jurídicas que não sejam de consumo stricto sensu.

Ibrahim, j. 14.10.2009; Apel. Cível no 2009.002.13393, TJRJ, 4ª Cam. Cível, Rel. Des. Monica Tolledo de Oliveira, j. 23.06.2009.

${ }^{431}$ Vale lembrar que o extinto Primeiro Tribunal de Alçada Civil do estado de São Paulo também se filiava à Teoria Finalista Clássica, conforme Apel. no 1186811-4, $8^{\mathrm{a}}$ Cam., Rel Des. Rubens Cury, j. 18.06.2003; AI $n^{\circ}$ 1073523-2, 8 a Cam., Rel Des. Franklin Nogueira, j. 24.04.02; AI nº 1057749-6/01, 8 Cam., Rel Des. Rubens Cury, j. 05.12.01; AI n ${ }^{\circ}$ 965374-1, 4ª Cam., Rel Des. José Marcos Marrone, j. 08.11.00.

${ }^{432}$ De acordo com Apel. $n^{\circ}$ 991.09.044664-0, TJSP, $11^{\text {a }}$ Cam. de Direito Privado, Rel. Des. Gilberto dos Santos, j. 05.11.2009; Apel. $n^{\circ}$ 992.07.032476-9, TJSP, 25 ${ }^{\mathrm{a}}$ Cam. de Direito Privado, Rel. Des. Antonio Benedito Ribeiro Pinto, j. 01.10.2009; Apel. no 7.306.572-8, TJSP, $21^{\mathrm{a}}$ Cam. de Direito Privado, Rel. Des. Itamar Gaino, j. 30.09.2009; Apel. $n^{\circ}$ 7.315.453-7, TJSP, $21^{\text {a }}$ Cam. de Direito Privado, Rel. Des. Itamar Gaino, j. 30.09.2009; Apel. $\mathrm{n}^{\mathrm{o}}$ 7.372.755-2, TJSP, $21^{\mathrm{a}}$ Cam. de Direito Privado, Rel. Des. Silveira Paulilo, j. 16.09.2009.

${ }^{433}$ Tal ocorreu, por exemplo, na Apel. $n^{\circ}$ 7.306.572-8, TJSP, $21^{\mathrm{a}}$ Cam. de Direito Privado, Rel. Des. Itamar Gaino, j. 30.09.2009; Apel. no 7.315.453-7, TJSP, $21^{\mathrm{a}}$ Cam. de Direito Privado, Rel. Des. Itamar Gaino, j. 30.09.2009; Apel. $\mathrm{n}^{\circ}$ 7.372.755-2, TJSP, $21^{\mathrm{a}}$ Cam. de Direito Privado, Rel. Des. Silveira Paulilo, j. 16.09.2009. 


\section{CONCLUSÃO}

Objetivou-se demonstrar, com o presente estudo, a necessidade de se tutelar a desigualdade substancial existente nas relações contratuais celebradas entre empresários, quando uma das partes, ainda que profissional, encontrar-se em situação de dependência econômica, favorecendo o abuso da parte contrária na situação concreta. Isso, porque, mesmo quando não existir solução legal específica a tutelar determinada situação, deve-se buscar sempre atingir o resultado concreto mais justo, restabelecendo o equilíbrio do contrato, que é fundamental às relações contratuais sinalagmáticas.

O cerne do trabalho girou em torno do problema das cláusulas abusivas no âmbito dos contratos interempresariais, buscando-se demonstrar que, nas hipóteses em que não for possível repreendê-las por meio da aplicação do Código Civil ou da Lei Antitruste, deve-se tentar buscar alternativas viáveis, já que relegar essa função aos princípios contratuais nem sempre será suficiente para um efetivo controle de tais cláusulas.

Muito se falou sobre a inutilidade do conceito de consumidor-equiparado para os empresários após a entrada em vigor do Código Civil de 2002, tendo em vista que este diploma legal introduziu diversos princípios sociais e institutos que têm por objetivo corrigir os desequilíbrios nos contratos celebrados entre iguais, além de ter tratado, em seu art. 424, das cláusulas abusivas, principal motivo de equiparação de empresários a consumidores. Entretanto, tentou-se demonstrar que não apenas as demais situações de equiparação permanecem válidas (como para a proteção da publicidade enganosa, por exemplo), como, inclusive, o conceito de consumidor-equiparado continua tendo importância para a aplicação do regramento das cláusulas abusivas previsto no CDC às relações entre profissionais.

Tal ocorre, porque o tratamento dado pelo art. 424 é muito restrito, não abrangendo todas as hipóteses de abusividade de uma cláusula, tampouco abrangendo toda e qualquer relação jurídica mantida entre profissionais. Ademais, a aplicação dos princípios contratuais depende muitas vezes de avaliações subjetivas pelo magistrado, o que pode acabar retardando o resultado do processo judicial ou até mesmo deixando o empresário sem respaldo.

Da mesma forma, a repressão aos abusos cometidos pelo contratante em posição privilegiada pelo direito concorrencial também pode não ser tão efetiva e célere como seria 
a repressão pelo $\mathrm{CDC}$, a depender do caso concreto. Isso se deve, notadamente, a dois fatos. Em primeiro lugar, porque as autoridades antitruste ainda se preocupam muito mais com as estruturas do que com os comportamentos e, em segundo, porque esse ramo do direito é baseado na regra da razão, de forma que o efetivo controle da conduta fica vinculado à comprovação de um dos ilícitos estabelecidos no art. 20 da Lei 8.884/94 - o que nem sempre será possível, conforme analisado.

Tanto isso é verdade que a própria jurisprudência brasileira vem aceitando cada vez mais a aplicação do diploma de proteção consumerista às relações interempresariais, desde que constatada a vulnerabilidade de um dos contratantes, atribuindo grande relevo ao conceito de consumidor-equiparado e delimitando os casos em que tal conceito há de prevalecer.

Em síntese do que foi exposto no capítulo 6 deste trabalho, pode-se dizer que, nos contratos negociados que não recebam a proteção especial dispensada aos participantes do contrato de adesão ou aos protagonistas das relações de consumo, deve-se prevalecer a liberdade contratual, que envolve, dentre outras, as faculdades de contratar ou não, de escolher com quem contratar e de escolher o conteúdo do contrato, cabendo, como pano de fundo, apenas, um controle das cláusulas abusivas por meio da aplicação dos princípios contratuais modernos, especialmente a boa-fé objetiva.

De fato, o exercício da autonomia da vontade implica um risco inerente à atividade contratual, que deve ser assumido pelas partes como ônus da própria conduta, não competindo ao legislador interferir nesse domínio, uma vez que a perfeição da formação e da exteriorização da vontade negocial já está plenamente assegurada pelas regras que disciplinam os vícios do consentimento ${ }^{434}$. Daí a importância de se precisar os casos de equiparação do empresário ao consumidor, exigindo-se a presença de todos os elementos que caracterizam a dependência econômica e, especialmente, a ocorrência de um abuso dessa dependência por parte do contratante em posição de superioridade.

Já nas relações de consumo stricto sensu ou nas hipóteses em que for possível a equiparação do empresário ao consumidor, segundo os critérios analisados anteriormente, por outro lado, terá aplicação o CDC, com as vantagens e proteções específicas que esse diploma legal oferece aos contratantes entendidos como vulneráveis, qualquer que seja o tipo de vulnerabilidade, especialmente a nulidade de pleno direito de todas as cláusulas

\footnotetext{
${ }^{434}$ Cf. MIRANDA, Custodio da Piedade Ulbadino. op. cit., p. 171.
} 
abusivas, elencadas no próprio código de consumo ou assim identificadas pelo aplicador do direito.

Não se pode olvidar, contudo, que a aplicação do CDC aos contratos interempresariais deve se dar apenas a título de exceção e não pode ter por objetivo eliminar o risco da atividade empresarial. A idéia aqui defendida deve ser vista como uma medida compensatória (assim como o é o próprio direito do consumidor), uma vez que não proporciona uma solução estrutural, mas visa corrigir algumas distorções dentro das possibilidades existentes em nosso ordenamento.

Especialmente por tal razão que não se deve abrir mão da comprovação da vulnerabilidade no caso concreto, como propõe a Teoria Finalista Aprofundada ou Mitigada. Esse parece ser o entendimento mais correto, para se atingir a solução mais justa no caso concreto, conferindo proteção aos profissionais sujeitos a abusos, sem, contudo, banalizar a aplicação do CDC. 


\section{REFERÊNCIAS BIBLIOGRÁFICAS}

AGUIAR JR., Ruy Rosado de. Projeto de Código Civil: as obrigações e os contratos. Revista de Direito Renovar, Rio de Janeiro, n. 15, 1999.

ALPA, Guido. Princípios gerais e direito dos contratos: um inventário de dicta e de questões. In: MONTEIRO, António J. M. Pinto (Coord.). Contratos: actualidade e evolução. Porto: Coimbra Ed., 1997.

ALTERINI, Atílio Aníbal. Os contratos de consumo e as cláusulas abusivas. Revista de Direito do Consumidor, São Paulo, v. 15, p. 5-19, 1995.

ALVIM, Arruda. Cláusulas abusivas e seu controle no direito brasileiro. Revista de Direito do Consumidor, São Paulo, v. 20, p. 25-70, 1996.

ALVIM, J. M. Arruda; ALVIM, Thereza; ALVIM, Eduardo Arruda; MARINS, Jayme. Código do Consumidor Comentado. 2. ed. São Paulo: Ed. Revista dos Tribunais, 1995.

ANDRADE JR., Attila de Souza Leão. Comentários ao novo Código Civil: parte geral. Rio de Janeiro: Forense, 2004. v. 1.

AZEVEDO, Antonio Junqueira de. A arbitragem e o direito do consumidor (arbitration and the consumer's rights). In: Estudos e pareceres de direito privado. São Paulo: Saraiva, 2004.

. Caracterização jurídica da dignidade da pessoa humana. In: Estudos e pareceres de direito privado. São Paulo: Saraiva, 2004.

Ciência do direito, negócio jurídico e ideologia. In: Estudos e pareceres de direito privado. São Paulo: Saraiva, 2004.

Cláusula cruzada de não-indenizar (cross-waiver of liability) ou cláusula de nãoindenizar com eficácia para ambos os contratantes. Renúncia ao direito de indenização. Promessa de fato de terceiro. Estipulação em favor de terceiro. [Parecer]. In:

Estudos e pareceres de direito privado. São Paulo: Saraiva, 2004.

O direito civil tende a desaparecer? Revista dos Tribunais, São Paulo, n. 472, p. 15-21, fev. 1975.

O direito pós-moderno e a codificação. In: Estudos e pareceres de direito privado. São Paulo: Saraiva, 2004. p. 55-63. 
AZEVEDO, Antonio Junqueira de. Insuficiências, deficiências e desatualização do Projeto de Código Civil (atualmente, código aprovado) na questão da boa-fé objetiva nos contratos. In: Estudos e pareceres de direito privado. São Paulo: Saraiva, 2004.

Interpretação do contrato pelo exame da vontade contratual. O comportamento das partes posterior à celebração. Interpretação e efeitos do contrato conforme o princípio da boa-fé objetiva. Impossibilidade de venire contra factum proprium e de utilização de dois pesos e duas medidas (tu quoque). Efeitos do contrato e sinalagma. A assunção pelos contratantes de riscos específicos e a impossibilidade de fugir do "programa contratual" estabelecido. [Parecer]. In: Estudos e pareceres de direito privado. São Paulo: Saraiva, 2004.

A lesão como vício do negócio jurídico. A lesão entre comerciantes. Formalidades pré-contratuais. Proibição de venire contra factum proprium e ratificação de atos anuláveis. Resolução ou revisão por fatos supervenientes. Excessiva onerosidade, base do negócio e impossibilidade da prestação. [Parecer]. In: Estudos e pareceres de direito privado. São Paulo: Saraiva, 2004.

Natureza jurídica do contrato de consórcio. Classificação dos atos jurídicos quanto ao número de partes e quanto aos efeitos. Os contratos relacionais. A boa-fé nos contratos relacionais. Contratos de duração. Alteração das circunstâncias e onerosidade excessiva. Sinalagma e resolução contratual. Resolução parcial do contrato. Função social do contrato [Parecer]. Revista dos Tribunais, São Paulo, v. 94, n. 832, p. 113-137, fev. 2005.

Rapport brésilien sur la révision contractuelle In: ASSOCIATION HENRI CAPITANT DES AMIS DE LA CULTURE JURIDIQUE FRANÇAISE. Journées Bresiliennes. Conferência proferida em São Paulo, em 26 de maio de 2005.

Relação jurídica que não é de consumo. Destinatário final. Cláusula abusiva [Parecer]. In: __ _ Estudos e pareceres de direito privado. São Paulo: Saraiva, 2004.

BECKER, Anelise. Teoria geral da lesão nos contratos. São Paulo: Saraiva, 2000.

BENJAMIN, Antônio Herman V. O conceito jurídico de consumidor. Revista dos Tribunais, São Paulo, v. 77, n. 628, p. 69-79, fev. 1988.

; MARQUES, Cláudia Lima; BESSA, Leonardo Roscoe. Manual de Direito do Consumidor. São Paulo: Ed. Revista dos Tribunais, 2008.

BETTI, Emilio. Teoria general del negocio jurídico. Trad. Espanhola. Madrid: Ed. Revista de Derecho Privado, 1995.

Teoria generale della interpretazione. Milano: Giuffrè, 1955.

BITTAR, Carlos Alberto (Coord.). Os contratos de adesão e o controle de cláusulas abusivas. São Paulo: Saraiva, 1991. 
BORBA, José Edwaldo Tavares. Direito societário. 11. ed. Rio de Janeiro: Renovar, 2008.

BORGES, Nelson. A teoria da imprevisão no direito civil e no processo civil. São Paulo: Malheiros Ed., 2002.

BOTTALlO, Eduardo Domingues. Abuso de poder econômico. Revista de Direito Público, São Paulo, v. 55/56, 1980.

BUONOCORE, Vincenzo. Trattado di diritto commerciale: l'impresa. Torino: G. Giappichelli, 2002. Sezione I, t. 2.I.

BURNS, Joseph W. A study of the antitrust laws: their administration, interpretation, and effect, New York: Central Book Company, 1958.

BUTTIGIEG, Eugene. Consumer and competition policies: synergy needed. Consumer Policy Review, v. 15, n. 5, p. 192-197, sep./oct. 2005.

CAMPILONGO, Celso Fernandes. Política, sistema jurídico e decisão judicial. São Paulo: Max Limonad, 2002.

CANARIS, Claus-Wilhelm. A liberdade e a justiça contratual na "sociedade de direito privado". In: MONTEIRO, António J. M. Pinto (Coord.). Contratos: actualidade e evolução. Porto: Coimbra Ed., 1997. p. 48-66.

CARDOSO, Débora Rezende. O fim negativo do contrato no Código Civil de 2002: resolução por onerosidade excessiva. In: MARQUES, Claudia Lima (Coord). A nova crise do contrato: estudos sobre a nova teoria contratual. São Paulo: Ed. Revista dos Tribunais, 2007. p. 529-558.

CARNELUTTI, Francesco. Teoria generale del diritto. 3. ed. Roma: Soc. Ed. del Foro Italiano, 1951.

CAVALIERI FILHO, Sérgio. Programa de responsabilidade civil. 4. ed. São Paulo: Malheiros Ed., 2003.

COELHO, Fabio Ulhoa. Curso de direito comercial. 8. ed. rev. e atual. São Paulo: Saraiva, 2004. v. 1.

COLLINS, Hugh. The law of contract. 3. ed. London: Butterworths, 1997.

COMPARATO, Fabio Konder. A proteção ao consumidor na Constituição Brasileira de 1988. Revista de Direito Mercantil, Industrial, Econômico e Financeiro, São Paulo, n. 80, 1990.

A proteção do consumidor: importante capítulo do direito econômico. Revista de Direito Mercantil, Industrial, Econômico e Financeiro, São Paulo, n. 15/16, p. 89-105, 1974. 
CORDEIRO, António Manuel da Rocha e Menezes. Da boa-fé no direito civil. Coimbra: Almedina, 2001. v. 1 e v. 2.

COSTA, Maria Aracy Menezes da. Os novos poderes/direitos oriundos do contrato no Código Civil de 2002 e no Código de Defesa do Consumidor: vontade das partes. In: MARQUES, Claudia Lima (Coord). A nova crise do contrato: estudos sobre a nova teoria contratual. São Paulo: Ed. Revista dos Tribunais, 2007. p. 226-246.

CUNHA, Daniel Sica da. A nova força obrigatória dos contratos. In: MARQUES, Claudia Lima (Coord). A nova crise do contrato: estudos sobre a nova teoria contratual. São Paulo: Ed. Revista dos Tribunais, 2007. p. 247-284.

DE LUCCA, Newton. Direito do consumidor. 2. ed. São Paulo: Quartier Latin, 2008.

DUBOUIS, Louis. La théorie de l'abus de droit et la jurisprudence administrative. Thèse pour le doctorat présentée a la Université de Poitiers, 1960.

FERNANDES, Marcelo Cama Proença. $O$ contrato de franquia empresarial. São Paulo: Memória Jurídica Ed., 2003.

FILOMENO, José Geraldo Brito. Manual de direitos do consumidor. São Paulo: Atlas, 1991.

FIRST, Harry; FOX, Eleanor M.; PITOFSKY, Robert. Revitalizing antitrust in its second century: essays on legal, economic, and political policy. New York: Quorum Books, 1991.

FONSECA, João Bosco Leopoldino da. Cláusulas abusivas. Revista de Direito do Consumidor, São Paulo, v. 16, p. 52-62, 1995.

FORGIONI, Paula Andréa. Contrato de distribuição. São Paulo: Ed. Revista dos Tribunais, 2005. . Os fundamentos do antitruste. São Paulo: Ed. Revista dos Tribunais, 1998.

- A interpretação dos negócios empresariais no novo Código Civil brasileiro. Revista de Direito Mercantil, Industrial, Econômico e Financeiro, São Paulo, v. 42, n. 130, p. 7-38, abr./jun. 2003.

FRIGNANI, Aldo. Il contratto di franchising. Milano: Giuffrè, 1999.

GAGLIANO, Pablo Stolze; PAMPLONA FILHO, Rodolfo. Novo curso de direito civil: parte geral. 7. ed. São Paulo: Saraiva, 2006. v. 1.

; __ Novo curso de direito civil: contratos. 3. ed. São Paulo, Saraiva, 2007. v. 4, t. 1 .

GILMORE, Grant. The death of contract. 2. ed. Columbus: Ohio State University Press, 1995. 
GODOY, Cláudio Luiz Bueno de. Função social do contrato. São Paulo: Saraiva, 2004.

GOMES, Orlando. Contratos. 17. ed., Rio de Janeiro: Forense, 1997.

Transformações gerais do direito das obrigações. São Paulo: Ed. Revista dos Tribunais, 1980.

GRAC, Stéphane. Les relations juridiques entre franchiseur et franchisé: coopération et conflit. Thèse pour le Doctorat présentée a l’Université de Nice-Sophia Antipolis, 1999.

GRAU, Eros Roberto; FORGIONI, Paula Andréa. Ainda um novo paradigma dos contratos? In: O Estado, a empresa e o contrato. São Paulo: Malheiros Ed., 2005.

GUERREIRO, José Alexandre Tavares. O Estado e a economia dos contratos privados. Revista de Direito Mercantil, Industrial, Econômico e Financeiro, São Paulo, n. 31, p. 7788, 1978.

. Formas de abuso de poder econômico. Revista de Direito Administrativo, Rio de Janeiro, n. 169, p. 199-214, jul./set. 1987.

GUESTIN, Jacques. L'abus dans les contrats. Gazette du Palais, Paris, n. 19-20, out. 1981.

Le juste et l'utile dans les effets du contrat. In: MONTEIRO, António J. M. Pinto (Coord.). Contratos: actualidade e evolução. Porto: Coimbra Ed., 1997. p. 123-165.

GUYON, Yves. Droit du marché et droit commun des obligations: rapport de synthèse. RTDcom, v. 51, n. 1, janv./mars. 1998.

HONDIUS, Ewoud. The notion of consumer: European Union versus Member States. Sydney Law Review, v 28, p. 89-98, 2006.

IRTI, Natalino. L'Età della decodificazione. 4. ed. Milano: Giuffrè, 1999.

KARAM-SILVEIRA, Marco Antonio. Contratos Cativos de longa duração: tempo e equilíbrio nas relações contratuais. In: MARQUES, Claudia Lima (Coord). A nova crise do contrato: estudos sobre a nova teoria contratual. São Paulo: Ed. Revista dos Tribunais, 2007. p. 482-503.

KARIMI, Abbas. Les clauses abusives et la théorie de l'abus de droit. Paris: E.J.A., 2001.

KELSEN, Hans. Teoria pura do direito. Trad. por João Baptista Machado. 6.ed. São Paulo: Martins Fontes, 2000.

KLANG, Marcio. A teoria da imprevisão e a revisão dos contratos. São Paulo: Ed. Revista dos Tribunais, 1983. 
KLEE, Antonia Espíndola Longoni. A unificação do direito privado e as relações entre o Código de Defesa do Consumidor e o Código Civil. Disponível em: <http://www.cjf.jus.br/revista/numero39/artigo08.pdf>. Acesso em: 04 nov. 2009.

KUHN, Adriana Menezes de Simão. O tempo e a catividade nos contratos: elementos para uma abordagem sistêmica da teoria dos contratos. In: MARQUES, Claudia Lima (Coord). A nova crise do contrato: estudos sobre a nova teoria contratual. São Paulo: Ed. Revista dos Tribunais, 2007. p. 453-481.

LIMA, Cíntia Rosa Pereira de. Nova principiologia contratual interpretada pela jurisprudência moderna: decadência do dogma pacta sunt servanda. In: HIRONAKA, Giselda Maria Fernandes Novaes (Coord.). A outra face do Poder Judiciário: decisões inovadoras e mudanças de paradigmas. Belo Horizonte: Del Rey, 2007. v. 2, p. 23-44.

LISBOA, Roberto Senise. Princípios gerais dos contratos. Revista dos Tribunais, São Paulo, v. 86, n. 745, p. 27-40, nov. 1997.

LÔBO, Paulo Luiz Neto. Condições gerais dos contratos e cláusulas abusivas. São Paulo: Saraiva, 1991.

LOPES, José Reinaldo de Lima. Responsabilidade civil do fabricante e a defesa do consumidor. São Paulo: Ed. Revista dos Tribunais, 1992.

LORENZETTI, Ricardo Luiz. Tratado de los contratos. Buenos Aires, Rubinzal-Culzoni Editores, 1999. t. 1.

LUHMANN, Niklas. Sistema giuridico e dogmatica giuridica. Traduzione e introduzione di Alberto Febbraio. Bologna: Il Mulino, 1978.

MACEDO JR., Ronaldo Porto. Contratos relacionais e defesa do consumidor. São Paulo: Max Limonad, 1998.

MARCONDES, Sylvio. Problemas de direito mercantil. São Paulo: Max Limonad, 1970. . Questões de direito mercantil. São Paulo: Saraiva, 1977.

MARQUES, Cláudia Lima. Campo de aplicação do CDC. In: BENJAMIN, Antônio Herman V.; MARQUES, Cláudia Lima; BESSA, Leonardo Roscoe. Manual de direito do consumidor. São Paulo: Ed. Revista dos Tribunais, 2008.

Contratos no Código de Defesa do Consumidor. São Paulo: Ed. Revista dos Tribunais, 2002.

. Contratos no Código de Defesa do Consumidor. 5. ed. São Paulo: Ed. Revista dos Tribunais, 2005. 
MARQUES, Cláudia Lima. Diálogo entre o Código de Defesa do Consumidor e o novo Código Civil: do "diálogo das fontes" no combate às cláusulas abusivas. Revista de Direito do Consumidor, São Paulo, n. 45, p. 71-99, jan./mar. 2003.

A Lei 8.078/90 e os direitos básicos do consumidor. In: BENJAMIN, Antônio Herman V.; MARQUES, Cláudia Lima; BESSA, Leonardo Roscoe. Manual de direito do consumidor. São Paulo: Ed. Revista dos Tribunais, 2008.

Relações de consumo na pós-modernidade: em defesa de uma interpretação finalista dos Artigos $2^{\circ}$ e 29 do CDC. Revista da Faculdade de Direito da Universidade Federal do Rio Grande do Sul, Porto Alegre, v. 19, p. 95-129, 2001.

Superação das antinomias pelo diálogo das fontes: o modelo brasileiro de coexistência entre o Código de Defesa do Consumidor e o Código Civil de 2002. Revista de Direito do Consumidor, São Paulo, v. 13, n. 51, p. 34-67, jul./set. 2004.

MARTINS-COSTA, Judith. A boa-fé no direito privado. São Paulo: Ed. Revista dos Tribunais, 2000.

MELLO, Adriana Mandim Theodoro de. Franquia empresarial: responsabilidade civil na extinção do contrato. Rio de Janeiro: Forense, 2001.

MENDONÇA, José Xavier Carvalho de. Tratado de direito comercial brasileiro. 3. ed. Rio de Janeiro: Freitas Bastos, 1937. v. 1.

MIRANDA, Custodio da Piedade Ulbadino. Contrato de adesão. São Paulo: Atlas, 2002.

MIRANDA, Francisco Cavalcanti Pontes de. Tratado de direito privado. 4. ed. São Paulo: Ed. Revista dos Tribunais, 1983. t. 6.

MORAES, Paulo Valério Dal Pai. O Código de Defesa do Consumidor: princípio da vulnerabilidade no contrato, na publicidade, nas demais práticas comerciais. Porto Alegre: Síntese, 1999.

MORATO, Antonio Carlos. Pessoa jurídica consumidora. São Paulo: Ed. Revista dos Tribunais, 2008.

MUSSI, Luiz Daniel Rodrigues Haj. Abuso de dependência econômica nos contratos interempresariais de distribuição. 2007. Dissertação (Mestrado) - Faculdade de Direito, Universidade de São Paulo, São Paulo, 2007.

NARASIMHAN, Subha. Individualism in american contract law: an i my brother's keeper. In: MONTEIRO, António J. M. Pinto (Coord.). Contratos: actualidade e evolução. Porto: Coimbra Ed., 1997.

NEGREIROS, Teresa. Teoria do contrato: novos paradigmas. 2. ed. Rio de Janeiro: Renovar, 2006. 
NERY JUNIOR, Nelson et al. Código Brasileiro de Defesa do Consumidor comentado pelos autores do Anteprojeto. 4. ed. Rio de Janeiro: Forense Universitária, 1995.

NOVAIS, Alinne Arquette Leite. A teoria contratual e o Código de Defesa do Consumidor. São Paulo: Ed. Revista dos Tribunais, 2001.

NUNES, Luiz Antonio Rizzato. Curso de direito do consumidor. 2. ed. São Paulo: Saraiva, 2005.

PENTEADO, Luciano de Camargo. Prefácio à $2^{\mathrm{a}}$ edição. In: TARTUCE, Flavio. Função social dos contratos: do Código de Defesa do Consumidor ao Código Civil de 2002. 2. ed. São Paulo: Ed. Método, 2007.

PETTY, Ross D.; HAMILTON, Jennifer. Seeking a single policy for contractual fairness to consumers: a comparison of U.S. and E.U. efforts. The Journal of Consumer Affairs, v. 38, n. 1, p. 149, Summer 2004.

PICOD, Yves. Droit du marché et droit commun des obligations - Rapport introductif. RTD Com., v. 51, n. 1, p. 2, janv.-mars - 1998.

REALE, Miguel. O novo Código Civil. Disponível em: <www.miguelreale.com.br>. Acesso em: 16 jan. 2009.

. Teoria tridimensional do direito: situação atual. São Paulo: Saraiva, 2003.

ROPPO, Enzo. O contrato. Coimbra: Almedina, 1988.

SALOMÃO FILHO, Calixto. Contrato de "franchising" e ilícito concorrencial. In:

Regulação e concorrência: estudos e pareceres. São Paulo: Malheiros Ed., 2002. p. 96-136.

Direito concorrencial: as condutas. São Paulo: Malheiros Ed., 2003.

SAMPAIO, Laerte Marrone de Castro. A boa-fé objetiva na relação contratual. São Paulo: Manole, 2004.

SARMENTO, Daniel. Direitos fundamentais e relações privadas. 2. ed. Rio de Janeiro: Lumen Juris, 2006.

SCAFF, Fernando Campos. As novas figuras contratuais e a autonomia da vontade. Revista da Faculdade de Direito da Universidade de São Paulo, São Paulo, v. 91, p. 141159, 1996.

SECKLER, Valérie. L'abus de dépendance économique. Memoire de Dea de Droit Privé de L’Université de Paris I (Pantheon - Sorbonne), 1991-1992.

SHIEBER, Benjamin M. Abusos do poder econômico: direito e experiência antitruste no Brasil e nos EUA. São Paulo: Ed. Revista dos Tribunais, 1966. 
SILVA, Fernando Borges da. O Código de Defesa do Consumidor: um microssistema normativo eficiente? Disponível em: <http://jus2.uol.com.br/doutrina/texto.asp?id=7564>. Acesso em: 13 ago. 2008.

STAGNI, Alexandre; NOGUEIRA, André Coutinho; CABELEIRA, Caio; OUCHANA, Elber Christian; GOMES, Guilherme Amado. Os princípios peculiares do direito comercial e a aplicação do Código de Defesa do Consumidor aos contratos interempresariais. Revista de Direito Mercantil, Industrial, Econômico e Financeiro, São Paulo, n. 145, p. 209-244, jan./mar. 2007.

TADDEI, Marcelo Gazzi. O direito comercial e o novo Código Civil brasileiro. Disponível em: <http://jus2.uol.com.br/doutrina/texto.asp?id=3004>. Acesso em: $24 \mathrm{dez}$. 2008.

TARTUCE, Flavio. A boa-fé objetiva e os amendoins: um ensaio sobre a vedação do comportamento contraditório (venire contra factum proprium non potest). Disponível em: <http://www.flaviotartuce.adv.br/secoes/artigos.asp>. Acesso em: 22 dez. 2008.

A boa-fé objetiva e a mitigação do prejuízo pelo credor. Esboço do tema e primeira abordagem. Disponível em: <http://www.flaviotartuce.adv.br/secoes/artigos.asp>. Acesso em: 22 dez. 2008.

Direito civil e Constituição. Disponível em: <http://www.flaviotartuce.adv.br/secoes/artigos.asp>. Acesso em: 22 dez. 2008. . A função social dos contratos, a boa-fé objetiva e as recentes súmulas do Superior Tribunal de Justiça. Disponível em: <http://www.flaviotartuce.adv.br/secoes/artigos.asp>. Acesso em: 22 dez. 2008.

Função social dos contratos: do Código de Defesa do Consumidor ao Código Civil de 2002. 2. ed. São Paulo: Ed. Método, 2007.

A revisão do contrato no Código de Defesa do Consumidor e a suposta adoção da teoria da imprevisão: visão frente ao princípio da função social do contrato. Disponível em: <http://www.flaviotartuce.adv.br/secoes/artigos.asp>. Acesso em: 22 dez. 2008.

- Sentença: a boa-fé objetiva e o dever do credor de mitigar a perda (duty to mitigate the loss). In: HIRONAKA, Giselda Maria Fernandes Novaes (Coord.). A outra face do Poder Judiciário: decisões inovadoras e mudanças de paradigmas. Belo Horizonte: Del Rey, 2007. v. 2, p. 45-68.

—. Tendências do novo direito civil: uma codificação para o $3^{\circ}$ milênio. Compreendendo a nova codificação. Disponível em: <http://www.flaviotartuce.adv.br/secoes/artigos.asp>. Acesso em: 22 dez. 2008.

TAUFICK, Roberto Domingos. Cartel, ilegalidade per se e ônus da prova: breves considerações. Revista de Economia, Curitiba, ano 31, v. 33, n. 1, p. 151-155, 2007. 
TEPEDINO, Gustavo. As relações de consumo e a nova teoria contratual. In: Temas de direito civil. Rio de Janeiro: Renovar, 1999.

TEPEDINO, Gustavo. Crise de fontes normativas e técnica legislativa na parte geral do Código Civil de 2002. In: A parte geral do novo Código Civil: estudos na perspectiva civil constitucional. Rio de Janeiro: Renovar, 2002.

TEUBNER, Gunther. Le droit, um système autopoïétique. Traduzido do alemão por Gaby Maier e Nathalie Boucquey. Paris: Presses Universitaires de France, 1993.

THEODORO JR., Humberto. Comentários ao novo Código Civil: dos defeitos do negócio jurídico ao final do livro III. Rio de Janeiro: Forense, 2003. v. 3, t. 1.

TOMASETTI JÚNIOR, Alcides. Abuso de poder econômico e abuso de poder contratual. Revista dos Tribunais, São Paulo, v. 84, n. 715, p. 87-107, maio. 1995.

VIRASSAMY, Georges J. Les contrats de dépendance: essai sur les activités professionnelles exercées dans une dépendance économique. Paris: L.G.D.J, 1986.

VIVANTE, Cesare. Trattato di diritto commerciale. 5. ed. Milano: Casa Editrice Dott. Francesco Vallardii, 1922. v. 1.

WALD, Arnoldo. O direito do consumidor e suas repercussões em relação às instituições financeiras. Revista dos Tribunais, São Paulo, v. 80, n. 666, p. 7-17, abr. 1991.

WATANABE, Kazuo et al. Código Brasileiro de Defesa do Consumidor comentado pelos autores do anteprojeto. 6. ed. Rio de Janeiro: Forense Universitária, 1999.

WIJCK, Peter van; THEEUWES, Jules. Protection against unfair contracts: an economic analysis of european regulation. European Journal of Law and Economics, v. 9, p. 73-89, 2000.

ZANETTI, Cristiano de Sousa. Direito contratual contemporâneo: a liberdade contratual e sua fragmentação. São Paulo: Método, 2008.

. Responsabilidade pela ruptura das negociações. São Paulo: Juarez de Oliveira, 2005. 